\title{
O poder pelo avesso: mandonismo, dominação e impotência em três episódios da literatura brasileira
}

\author{
Jean Pierre Chauvin
}

Tese apresentada ao Departamento de Teoria Literária e Literatura Comparada da Faculdade de Filosofia, Letras e Ciências Humanas da Universidade de São Paulo, como requisito para obtenção dos créditos de Doutorado.

Orientador: Prof. Dr. Marcus Vinícius Mazzari

São Paulo 
Há pessoas que marcaram e existe a que permanece. Há seres que fizeram bem, mas vive aquela que me faz melhor. Há dias em que sinto muito; os restantes serão para sentir tudo.

Força, sempre, Grazi. 


\title{
Agradecimentos
}

\author{
A Marcus Vinícius Mazzari, \\ pela segurança e paciência com que orientou a feitura deste trabalho. \\ Pelas colaborações de José Antônio Pasta Júnior \\ e Hélio Seixas Guimarães, também por ocasião da qualificação (2005).
}

A Alfredo Bosi e Doris Natia Cavallari, pelas sugestões e recomendações bibliográficas.

A minha filha, Morgana Miranda Chauvin, pelas dose de amor, compreensão e sabedoria com que (me) amadurece.

Ao carinho, à paciência e o apoio de mãe, pai e irmão: Maria do Socorro Carvalho, Pierre e Henri Chauvin.

A Pedrília e Luiz Antenor Mantoaneli, meus padrinhos.

Aos amigos Caio Alexandre Bezarias, Carlos Alexandre Campos Dantas, Fábio Di Dário, Fábio Oliveira Pagan, Helder Rossi, Isabel Pacheco Bernini, Lili Menezes, Luciana de Paula Spedine, Marco Antonio de Menezes, Patrícia Bianchini (que também auxiliou em muito na versão do "Resumo" para o inglês) e Priscila Verduro Bezarias.

Aos alunos e colegas do Mega Vestibulares (2002), CIPS (2002-2005), Cursinho Síntese (2003), Colégio Paralelo (2005-2006) e Eros Vestibulares (2006)
A Maria Ângela Aiello Bressan Schmidt e Luiz de Mattos Alves (DTLLC), pela atenção de sempre.

Aos professores e colegas de trabalho do IBUSP (1997 - 2006), pela amizade e estímulo aos estudos e demais atividades extra-funcionais:

Elizabeth Höfling, Sergio Antonio Vanin, Miguel Trefaut Rodrigues,

Sérgio Luiz de Siqueira Bueno, Fábio Lang da Silveira, Marly Salviano de Almeida e, especialmente, Abigail Lais de Barros Bartholomeu. 
“ - Cada autor tem a sua maneira própria de fazer valer seus interesses; -- de minha parte, como detesto regatear e discutir por uns poucos guinéus, num portal escuro; --decidi comigo mesmo, desde o princípio, negociar aberta e honradamente convosco, Gente Importante, neste assunto, a ver se não me sairia tanto mais vantajosamente dele.” (Tristram Shandy, Sterne)

“Je consacre mes derniers jours à m’étudier moi-même et à préparer d'avance le compte que je ne tarderai pas à rendre de moi.”(Les rêveries du promeneur solitaire, Rousseau)

* Consagro meus últimos dias a estudar a mim mesmo e preparar de antemão a (minha) conta que não tardarei a prestar. 


\section{Índice}

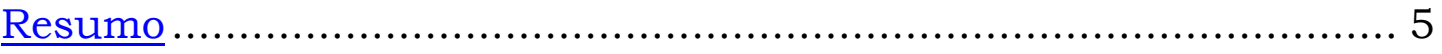

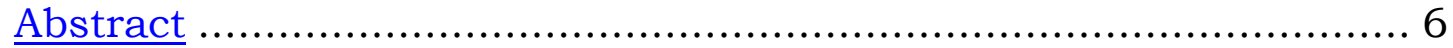

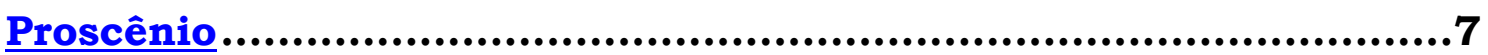

Burocratas entre o jornal e o livro............................................ 15

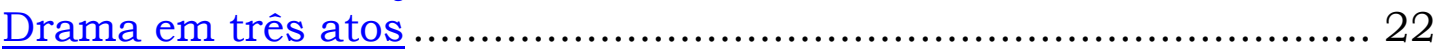

Literatura como remate de males ............................................ 27

PARTE I - POTÊNCIA (Mando) …..........................................31

Manuel Antônio de Almeida: recuo estratégico ...........................32

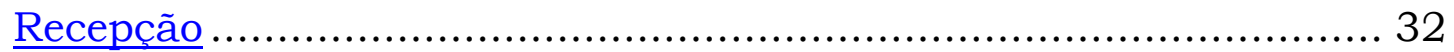

Recuo estratégico ……....................................................... 39

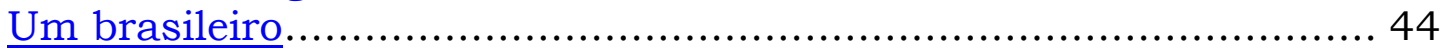

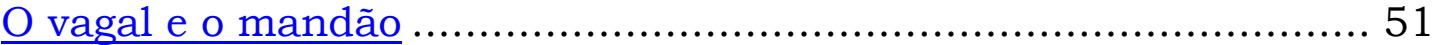

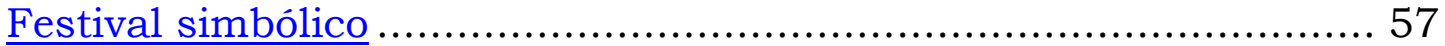

PARTE II - PREPOTÊNCIA ...........................................62

Machado de Assis: capítulo à parte........................................63

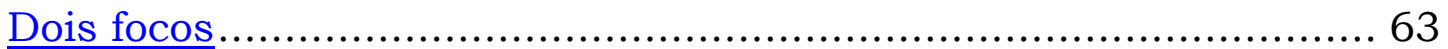

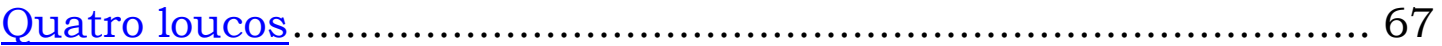

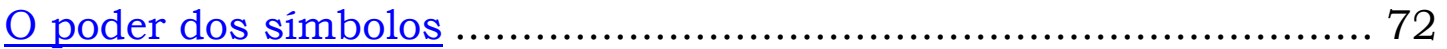

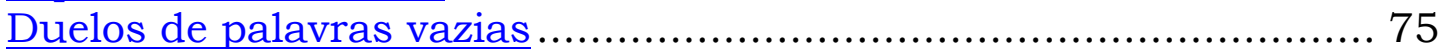

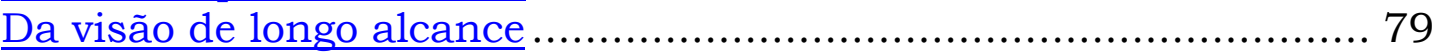

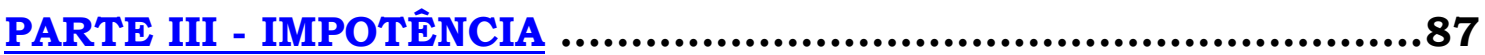

Lima Barreto: lúcidos e marionetes.......................................88

Vida e morte: o panfleto em fogo brando .................................... 92

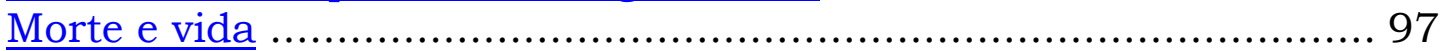

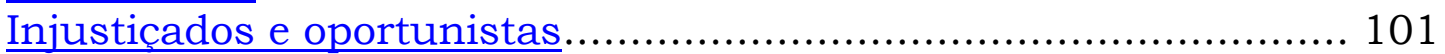

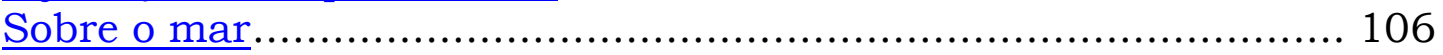

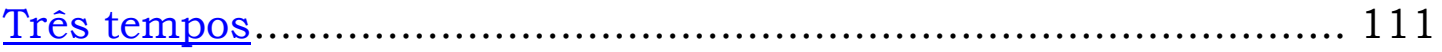

Bastidores..................................................................118

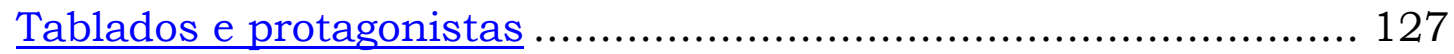

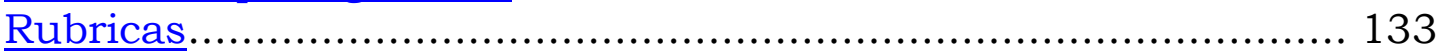

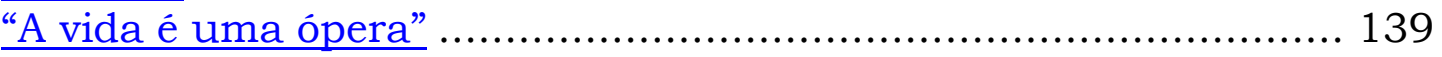

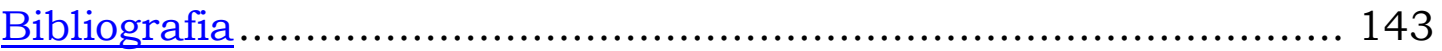




\section{Resumo}

Este trabalho pretende anotar comparativamente Memórias de um Sargento de Milícias (1855), O Alienista (1882) e Vida e morte de M. J. Gonzaga de Sá (1919), com vistas a resgatar também a contribuição de estudiosos predecessores. Três obras a fornecer subsídios sobre o que pode haver de cômico e sério, no material do mundo de verdade, re-trabalhado sob a ótica de escritores que empregaram a Corte ou a República como cenário.

Autores que, ao configurar tais personagens, nutriram-se de expedientes através dos quais os textos dialogam, em alguma medida, entre si: a anedota zombeteira, patente em Almeida, combina-se à crônica à beira do inverossímil, na novela de Machado. À parte o riso que despertam, estão possivelmente próximos, não apenas do ponto de vista estilístico, do romance de Lima.

Nos três casos, os enredos se constituem a partir dos retratos e trajetórias das figuras centrais, todas mais ou menos deslocadas frente às convenções sociais. Em seu tempo e à sua maneira, Almeida, Machado e Lima traçaram paralelos entre certos procedimentos de suas personagens e aqueles dos homens não-ficcionais: uns e outros vivendo à base de fachadas. Literatura a desmontar o palco Brasil, para divertimento e drama dos leitores. 


\section{Abstract}

The purpose of this work intends to note comparativily Memórias de um Sargento de Milícias (1855), O Alienista (1882) and Vida e morte de M. J. Gonzaga de Sá (1919), with sights to also bring back the contribution of studious predecessors. Three studies supplying subsidies on what it can be of serious and comic regarding to the material of the true world, re-studied under the writers views who had used either the Court or the Republic as scene.

Authors who, while configuring such personages, were fed by the expedients through which the texts, dialogue, in some way, itself: a mocking anecdote, which is clear in Almeida, agrees with the chronicle almost true, in the story of Machado. In spite of the laughs that ignite, they are possibly closer to the romance of Lima not only of the stylistic point of view.

In the three cases, the plots constitute themselves through the pictures and trajectories of main characters, which more or less dislocated against the social conventions. In its time and way, Almeida, Machado and Lima had traced parallels between certain procedures of the personages and those of the non-fictional persons: some and others living to the base of veils. Literature disassembles the Brazilian stage, for entertainment and drama of the readers. 


\section{Proscênio}

A rigor, este trabalho não traz um tema exatamente novo. Manuel Antônio de Almeida, Machado de Assis e Lima Barreto - "romancistas da cidade”, como define parte da crítica $^{1}$ - marcaram estética e ideologicamente a literatura de fundo social urbano, concentrados na representação da vida de cidadãos de estrato provinciano, tendo o Rio de Janeiro e seus arredores como tablado.

Memórias de um Sargento de Milícias é reconhecido por ter gravado o nome de Almeida na história de nossa literatura. De tempos em tempos, o livro é reapresentado à lembrança dos leitores por conta de suas reedições, acompanhadas de novos estudos introdutórios. Destaquem-se os trabalhos recentes de Mamede Mustafa Jarouche (edição crítica do romance, de 2003) e Reginaldo Pinto de Carvalho (reedição das Memórias na versão em folhetim, de 2004).

Nesse romance, o detalhamento dos espaços, o deslocamento temporal e a pormenorização do vestuário - este, diretamente associado à caracterização interna e externa das personagens -, são recursos que simultaneamente lembram os trechos descritivos dos prosadores da época e burlam os seus padrões romanescos.

É que na forma, a narrativa parodia o jargão romanesco romântico. No conteúdo, apoiado em constantes assertivas irônicas, ridiculariza os costumes sociais. Em lugar de heróis nacionais com nomes importados ou de origem tupi (culturalmente enobrecidos, quase europeizados), homens do povo com tentações e ambições socioeconômicas. Idealização nenhuma; arruaça, aventura, amoralismo.

O Alienista abre a coletânea Papéis Avulsos e marca a chamada segunda fase machadiana. Publicado praticamente na mesma época das Memórias Póstumas de Brás Cubas, seguiu percurso similar ao do romance: do jornal (entre 1881 e 1882) para o livro (1882).

Apesar das óbvias diferenças em relação à autobiografia do “defunto autor” extensão, enredo, caracterização das personagens e posição dos narradores -, a novela representa uma revolução de forma e conteúdo que não se repetiu entre as narrativas machadianas de menor extensão.

\footnotetext{
${ }^{1}$ Especialmente Astrojildo Pereira e Miécio Táti. Nos manuais de literatura do nível médio é comum Memórias de um Sargento de Milícias ser definido como "romance de costumes", subclassificação do também chamado "romance urbano". As referências completas das obras e estudos citados no trabalho constam da "Bibliografia", ao final deste, com exceção àquelas mencionadas apenas a título de ilustração. Nesses casos, a fonte foi transcrita integral e exclusivamente nas notas de rodapé.
} 
A crítica considera que na fase da maturidade, Machado compôs vários "contosteoria”², como O espelho, Teoria do medalhão, A igreja do diabo, O segredo do Bonzo, Missa do galo, entre tantos outros. O presente estudo segue raciocínio parecido, mas aqui defende a idéia de que $O$ Alienista se destaca principalmente por sintetizar a maior parte dos recursos ficcionais de Machado, inclusive aqueles percebidos pelos estudiosos de seus romances.

O Alienista seria uma espécie de chave-mestra para se abordar a prosa machadiana de maior fôlego. Desse ponto de vista, não parece justo o papel de mera obra coadjuvante, a reboque do carro-chefe machadiano Memórias Póstumas de Brás Cubas.

Não foi apenas o romance que marcou a fase “realista” de Machado. Também se deve dar crédito a suas narrativas de menor extensão, notadamente $O$ Alienista: ficção com paródias no nível discursivo e alusões a eventos políticos e históricos - não exclusivamente nacionais - cujo enredo oscila do verossímil ao fantástico, favorecido pelas manipulações do narrador e o manifesto contraste socioeconômico e moral entre as personagens. Com Alfredo Bosi:

"À medida que cresce em Machado a suspeita de que o engano é necessidade, de que a aparência funciona universalmente como essência, não só na vida pública mas no segredo da alma, a sua narração se vê impelida a assumir uma perspectiva mais distanciada e, ao mesmo tempo, mais problemática, mais amante do contraste. (...) A partir das Memórias póstumas e dos contos enfeixados nos Papéis avulsos importa-lhe cunhar a fórmula sinuosa que esconda (mas não de todo) a contradição entre parecer e ser, entre a máscara e o desejo, entre o rito claro e público e a corrente escusa da vida interior.” (p. 84)

Basta relembrar as teorias do itaguaiense Simão Bacamarte, protagonista da novela, para aproximá-lo do ocioso fluminense Brás. Ambos - alienista que aliena a si mesmo e narrador revivido ${ }^{4}$, ainda que balizado pela própria morte - morrem exauridos por perseguir “idéias fixas”: o bem humanitário mal disfarça a sede de celebridade.

Vida e morte de M. J. Gonzaga de Sá é o mais breve romance barretiano e a linguagem demonstra seu possível maior cuidado frente às modestas reações dos leitores da época.

\footnotetext{
${ }^{2}$ Expressão empregada por Alfredo Bosi ( $O$ enigma do olhar). Roberto Schwarz defende que em "Teoria do medalhão" está contida a "chave satírica do Machado da maturidade” (Um mestre na periferia do capitalismo).

${ }^{3}$ Machado de Assis: o enigma do olhar.

${ }^{4}$ Sobre Memórias Póstumas de Brás Cubas, Bosi observou que: “O leitor sai com o sentimento de que, em certas passagens, o mundo das idéias e valores do defunto autor não só conserva, pela memória, como supera, pela reflexão, o pequeno mundo do jovem Brás.” (Brás Cubas em três versões, p. 17).
} 
A narrativa não trata de grandes feitos ou da trajetória de homens exatamente célebres. Os dias finais de Gonzaga revestem-se de melancólicas mensagens, algumas presumivelmente defendidas pelo próprio autor, ${ }^{5}$ que, nessa obra, equilibra o tom de manifesto a uma cuidadosa elaboração formal.

O enredo talvez não empolgue tanto o leitor de hoje, como acontece em Triste fim de Policarpo Quaresma. Uma explicação pode ser a de que a biografia do sexagenário Gonzaga de Sá pretendia se concentrar num menor intervalo de tempo já que não interessa ao narrador Augusto Machado relatar os percalços heróicos, os alaridos das gentes ou a celebração das festas animadas, mas sim, os finos diálogos com o amigo.

Acima de tudo, é uma narrativa de teor confessional - do protagonista ao narrador; do autor para o narrador - marcada, a maior parte do tempo, pelo tom de mansuetude de ambos. Nos raros episódios em que se evidencia a contestação de Gonzaga frente a determinadas posturas de seus conterrâneos, seu protesto não é vociferado; beira o sussurro. Sinal de modéstia ou impotência?

Mandar recados aos leitores não exclusivamente de seu tempo é uma função a que se ajusta a personagem principal: um idoso contestador político aparentemente sem a energia necessária para colocar suas teorias em prática. Grandes idéias para uma voz agora apequenada. Seu espírito, ainda revolto é abrandado pelo fastio a que se combina a pacata profissão e o ambiente ameno que divide com sua tia Escolástica.

\section{II}

Os autores em questão recuaram os eventos em suas narrativas para épocas cruciais, aludindo a certos dados da história nacional: a vinda da Corte ao Brasil (início do século XIX: Memórias de um sargento de milícias); a Revolução Francesa (17891892), a Conjuração Mineira e as reformas de Luiz Vasconcelos no Rio de Janeiro (final do século XVIII: O Alienista); e a mudança do Império para a República (virada do século XIX para o XX: Vida e morte de M. J. Gonzaga de Sá).

Almeida, Machado e Lima pouco ou nunca saíram da cidade onde nasceram. Essa coincidência, associada ao fato de terem sido homens absolutamente inteirados das picuinhas e turbulências políticas nacionais pode ter motivado a abordagem de temas

\footnotetext{
${ }^{5}$ De acordo com Bakhtin: "Entre todos os valores artísticos, o biográfico é o menos transgrediente à consciência; por isso na biografia o autor está mais próximo do herói desta, os dois como que podem trocar de lugar, e por esta razão é possível a coincidência pessoal entre personagem e autor além dos limites do todo artístico.” (Estética da criação verbal, p. 139)
} 
ligados à administração luso-brasileira - notadamente certas arbitrariedades do Império ou República, sob a forma de mandonismo e dominação, sempre com o amparo da lei.

Em suas obras, o exercício da linguagem (fosse para estabelecer vínculos imediatos com os leitores e/ou satirizar a pompa retórica dos homens de classe) combina-se aos conteúdos que enfocam determinados costumes e símbolos de representação, talvez como forma de questionar certos rituais ${ }^{6}$ do poder em episódios ligados a eventos históricos providencialmente imprecisos.

Da história das celebridades para a história da vida privada. Fugindo à apurada descrição dos espaços domésticos, comum a boa parte de nossos autores do século XIX, o predomínio dos locais abertos. Em vez de abordar a gestualidade condizente com os encontros de salão, os esbarrões na rua. Os cenários condizem com a festa, a rebelião e a caminhada.

Tal artifício revela a ênfase na ação marcada pelos contatos conflitantes, cujos movimentos envolvem as diversas camadas sociais retratadas por lá - diferentemente das longas, esmiuçadas e refinadas conversas formais entre "iguais" ou entre protetores e agregados ou demais aspirantes à alta roda, como se vê nos romances convencionais românticos e, inclusive, em algumas obras do Realismo. Segundo Gilda de Mello e Souza:

“(...) a festa pode ser a lenta antecâmara do casamento, onde os seres se auscultam e os instintos se jogam (...) produzindo não só os contatos fortuitos, as conversas a dois, as confissões veladas cheias de reticência, mas as competições de salão.” (p. 149) ${ }^{7}$

À análise dos narradores e personagens ajuntam-se observações sobre as categorias de tempo cronológico e espaço episódico, considerando-se o papel “aglutinador” reservado aos locais particulares e públicos: residências, prisões, sacristias, barbearias e repartições públicas.

Estudar os ambientes freqüentados pelas personagens revela algo das intenções de cada autor, a começar pela seleção de certos locais em detrimento de outros. A rua, contudo, concentra o maior significado: permite aos protagonistas participar de encontros festivos, atender a compromissos profissionais ou refletir, simplesmente.

\footnotetext{
${ }^{6}$ Conforme Roberto DaMatta: “O ritual tem (...) como traço distintivo a dramatização, isto é, a condensação de algum aspecto, elemento ou relação, colocando-o em foco, em destaque, como ocorre nos desfiles carnavalescos e nas procissões, onde certas figuras são individualizadas e assim adquirem um novo significado, insuspeitado anteriormente, quando eram apenas partes de situações.” (Carnavais, malandros e heróis, p. 36)

${ }^{7}$ Op. Cit.
} 
Espaço eminentemente público, a rua ilustra o dinamismo ${ }^{8}$, a ininterrupção, a falta de lugar fixo. Em termos extra-literários:

“a oposição entre rua e casa é básica, podendo servir como instrumento poderoso na análise do mundo social brasileiro, sobretudo quando se deseja estudar sua ritualização. De fato, a categoria rua indica basicamente o mundo, com seus imprevistos, acidentes e paixões, ao passo que casa remete a um universo controlado, onde as coisas estão nos seus devidos lugares. Por outro lado, a rua implica movimento, novidade, ação, ao passo que a casa subentende harmonia e calma: local de calor (como revela a palavra de origem latina lar, utilizada em português para casa) e afeto." (pp. 90-1)

Tais indícios não parecem gratuitos, mesmo porque remetem ao desenho de certos rituais ligados à história de nossa sociedade, pautados na conhecida indistinção entre o público e o privado. Não é por outro motivo que Vidigal age diferentemente em relação a Leonardo-filho. Trata-se de retribuir extra-oficialmente os favores íntimos prometidos por Maria Regalada. Não é por coincidência que Simão Bacamarte abre uma brecha em sua rígida terapêutica, ao estabelecer o regime de semi-internato exclusivamente para seu escudeiro Crispim Soares. Também há alguma confusão entre coleguismo de repartição pública e amizade, como se percebe na relação entre Gonzaga de Sá e o servente Romualdo.

O exame dessas obras pretende articular-se por meio de certos aspectos vinculados não exclusivamente à sua composição (enredo, narradores, personagens e símbolos). Por outro lado, espera-se que cada um dos estudos comporte sua margem de autonomia, já que as narrativas parecem orientadas sob três perspectivas do poder: mandonismo (Vidigal), dominação (Bacamarte) e impotência (Gonzaga de Sá).

Os enredos se desenvolvem em função de suas respectivas personagens centrais, e estas, a partir de dois focos narrativos: narradores oniscientes - ora neutros ora intrusos, com se vê em Almeida e Machado - e narrador testemunha, percebido no romance de Lima. ${ }^{10}$

\footnotetext{
${ }^{8}$ Segundo Raúl Castagnino: "alguns estetas sustentam que quando um traço priva exageradamente na configuração moral do personagem, já não se trata de um caráter, mas de uma paixão. Cabe, então, a denominação de 'tipo', que será 'protótipo' se primeiro em uma série e 'arquétipo', se modelo nela. Segundo os preceitistas clássicos, a perfeição artística de um caráter, à parte da continuidade, harmonia e equilíbrio de suas manifestações, ocorre na mobilidade, na ação. Vita in motu setenciavam os retóricos latinos e a mobilidade dos caracteres - sua conduta, portanto - provém do choque de paixões na alma dos personagens e do acordo ou desacordo de suas resultantes com a circunstância exterior.” (Análise literária, p. 127)

${ }^{9}$ Roberto DaMatta. Op. Cit.

${ }^{10}$ Embora as peripécias marquem o romance de Manuel Antônio de Almeida e a novela de Machado de Assis, as abordagens presentes não se detiveram estritamente na ação, embora tal categoria constitua um ingrediente digno de estudo, justamente nas Memórias e em O Alienista. A categoria tempo foi pouco valorizada por Machado e Lima, o que parece confirmar o interesse de ambos mais nas causas e efeitos (ação), e particularmente em especulações propriamente ditas, como se nota com aparente ainda maior seriedade no romance barretiano.
} 
Levando em conta os tons das narrativas, essa diferença de perspectiva pode ser decisiva. Almeida e Machado se utilizaram de um narrador em terceira pessoa para afetar uma irônica neutralidade diante dos "fatos". Lima serviu-se de um narradortestemunha certamente com o objetivo de transmitir maior credibilidade ao leitor.

Em todos, explicita-se o distanciamento temporal frente ao momento histórico em que se agitam seus protagonistas. Por isso, o recuo cronológico que promovem em suas narrativas parece integrar um projeto maior, de cunho anti-ficcional.

Não se tratava meramente de divertir os leitores, mas lembrá-los do contato entre a ficção que diverte e a bruta realidade. Para tanto, concorria a proposital intercalação entre a narração solene (pseudo-história) e familiar (pseudo-crônica): manobra dupla dos narradores em face de determinados episódios. Daí a opção pelos confrontos nas atitudes e discursos, em lugar de conchavos entre as figuras.

A alternância entre informações e comentários, por parte dos narradores, estende-se à descrição ora atípica ora caricatural de algumas personagens e celebridades históricas, inclusive. Acrescentem-se as patéticas desfeitas entre protagonistas e antagonistas e a funcionalidade questionável de determinados locais, como a Guarda Real (Milícias), a Casa Verde (O Alienista) e a Secretaria (Gonzaga de Sá). Certos eventos também dizem respeito sobre o funcionamento da máquina administrativa e política, em tempos nem tão remotos.

Tudo está em questão: dos rituais cotidianos privados aos cerimoniais públicos transplantados para cá, em caráter oficial e oficioso. Conforme a análise de Maria Ribeiro:

"é o conjunto mágico das cerimônia e dos símbolos que permite ao Império ser visto e vivenciado. Os gestos, assim como as palavras, e as diferentes categorias de objetos mostram com evidência a natureza do Estado que o soberano representa - encerram consciente ou inconscientemente um discurso sobre o Estado. A bandeira, as condecorações, os selos e a coroa imperial prolongam este discurso e fazem do imperador um personagem quase onipresente, visto por toda parte e por todos” (p. 101) ${ }^{11}$

O distanciamento temporal entre os narradores e os acontecimentos que reportam é outro expediente comum. Em Memórias de um Sargento de Milícias e em $O$

\footnotetext{
${ }^{11}$ Os símbolos do poder. A esse respeito, Rodriguez Lopes complementa: “A figura do Regente aparece, na descrição, como o centro que regulava a sociedade, agente que pairava acima dos demais protagonistas e que, quando invocado, tinha o poder de cicatrizar as feridas abertas no corpo social. (...) Habilmente, as autoridades recuperavam a festa como espaço de mediação pelo qual se podia dar um sentido de pertencimento e de unidade, fazendo crer que seria viável a superação dos conflitos que ocorriam no interior da sociedade.” (p. 43) “a ausência física do monarca era compensada por representações e especialmente por seu retrato, o que permitia sua presença simbólica, elemento fundamental na idealização da unidade social e no fortalecimento dos laços de pertencimento à Nação portuguesa.” (Festas públicas, memória e representação, p. 44)
} 
Alienista, a constante intromissão do narrador relembra ao leitor que as peripécias vividas respectivamente por Leonardo-filho e Simão Bacamarte não estão apartadas do que ainda vigorava para além dos domínios ficcionais.

Já Lima Barreto, talvez com a intenção contrária - ou seja, não deixar a narrativa escapar ao verossímil - pela primeira e última vez, como romancista, optou pelo foco narrativo de um "eu como testemunha”, que, nas palavras de Norman Friedman:

"é um personagem em seu próprio direito dentro da estória, mais ou menos envolvido na ação, mais ou menos familiarizado com os personagens principais, que fala ao leitor na primeira pessoa. A conseqüência natural desse espectro narrativo é que a testemunha não tem uma acesso senão ordinário aos estados mentais dos outros: logo, sua característica distintiva é que o autor renuncia inteiramente à sua onisciência em relação a todos os outros personagens envolvidos e escolhe deixar sua testemunha contar ao leitor somente aquilo que ele, como observador, poderia descobrir de maneira legítima.” (pp. 175-6) ${ }^{12}$

Não é por acaso que se trata de biografias. Apesar de situados em focos diversos, os narradores das três obras aproximam-se do universo do leitor através de interferências satíricas (Almeida e Machado) e depoimentos de resignação (em Lima, os diálogos das personagens tomam o lugar das intervenções de um narrador anônimo). Biografias de feições diferentes para apreender situações e tons opostos, aceitando a conceituação de Bakhtin:

"São possíveis dois tipos básicos de consciência biográfica axiológica e enformação da vida em função da amplitude do mundo biográfico (...) e do caráter da alteridade investida de autoridade; ao primeiro tipo chamamos de aventuresco-heróico, ao segundo, de tipo social-de-costumes (o sentimentalismo, e em parte, o realismo)." (pp. 142-3) "No segundo tipo costuma ser mais individualizada a maneira de narrar, mas a personagem-narradora se limita a amar e observar e quase não age, não é produto da fabulação, vive "cada dia” e gasta seu ativismo observando e narrando.” (p. 148) ${ }^{13}$

Também deve ser dada atenção ao gênero híbrido de tais obras. Trata-se de ficções em que a narrativa, nutrida com os elementos do passado ${ }^{14}$, aporta características formais da crônica. ${ }^{15}$ Essa configuração ilustra a possível intenção de fundir os dados históricos e os elementos do cotidiano. Por isso, a sensação de que tudo

\footnotetext{
12 “O ponto de vista na ficção”. Revista USP, 53, 2002.

${ }^{13}$ Estética da criação verbal.

${ }^{14}$ De acordo com Ian Watt: "no romance, mais que em qualquer outro gênero, as verdades só existem post res". (A ascensão do romance, p. 13)

${ }^{15}$ Para João Pachedo: “o livro em muitos pontos, tem um fundo documentário” [sic] (O Realismo, p. 20). Conforme Mário de Andrade: trata-se de uma "crônica semi-histórica” das peripécias de Leonardo-filho "sem delicadeza de análise" (Aspectos da literatura brasileira, p. 125). Conforme Erich Auerbach: "O princípio estético que está na base do Realismo moderno já tinha sido proclamado por Victor Hugo e seu grupo, por volta de 1830, um pouco antes da publicação dos primeiros romances realistas: é o princípio da mistura dos gêneros, que permite tratar de maneira séria e mesmo trágica a realidade cotidiana, em toda a extensão de seus problemas humanos, sociais, políticos, econômicos, psicológicos" (Introdução aos estudos literários, p. 242).
} 
está no tempo presente, apesar dos recuos cronológicos.

Por vezes, o alinhamento do dado supostamente real, verossímil, com o fantástico reforça a idéia de que uma das motivações comuns aos escritores era contradizer as fórmulas romanescas convencionais. Em lugar de meramente descrever com abundância de pormenorizações - traço característico das estéticas romântica e realista -, os narradores parecem encarar o passado e seus desdobramentos no presente, não como algo somente pictórico, mas propenso à ridicularização, seja em tom de gracejo ou de seriedade.

A intenção dos autores também seria explicitar certos dados de inautenticidade entre nós, brasileiros? Se a resposta for afirmativa, talvez por esse motivo algumas figuras tivessem sido desenhadas de forma afetada. A caricatura, aliás, é respaldada pelas roupas que, próprias para o clima temperado, moldavam os homens que vinham para cá e seus imitadores, ciosos dos distintos hábitos europeus. Daí o uniforme do Major Vidigal, a indumentária do Doutor Bacamarte e mesmo a antiga casaca do amanuense Gonzaga de Sá.

Quanto às ações das personagens, o mandonismo de Vidigal, a prepotência de Bacamarte e a impotência de Gonzaga constituem termos de um mesmo nó constitutivo de nossa história. Alguns significados da dominação, aliás, percorrem as três obras, explícita ou implicitamente.

Tomando de empréstimo a conceituação de Max Weber, enquanto Leonardofilho representa de certo modo um obstáculo à “dominação tradicional” (centrada na figura do Rei), e Simão Bacamarte poderia ser caracterizado como "dominador carismático” (cujo domínio é atribuído e reconhecido pelo povo), Gonzaga de Sá luta intelectualmente contra a “dominação legal”:

“dominação em virtude de estatuto. Seu tipo mais puro é a dominação burocrática. Sua idéia básica é: qualquer direito pode ser criado e modificado mediante um estatuto sancionado corretamente quanto à forma. (...) Obedece-se não à pessoa em virtude de seu direito próprio, mas à regra estatuída, que estabelece ao mesmo tempo a quem e em que medida se deve obedecer.” (pp. 128-9) ${ }^{16}$

São narrativas que permitem refletir sobre as razões da literatura em seu papel de arte civilizadora, como definem alguns. ${ }^{17}$ Mofa, paródia e inconformismo poderiam alertar o leitor, fosse com requintes de humor ou seriedade, contra determinados logros,

\footnotetext{
${ }^{16}$ Gabriel Cohn (org). Max Weber - Sociologia.

17 Tal concepção aparece em ensaios e apontamentos dos três escritores, inclusive. Boa parcela de nossa crítica se serviu dos mesmos autores, entre outros, para ilustrar a idéia de que a literatura, além de sua natureza estética, cumpre um importante papel frente às ideologias do ambiente de produção de seu
} 
especialmente no campo das politicagens.

\section{Burocratas entre o jornal e o livro}

Dos autores abordados neste trabalho, dois são classificados nos manuais de literatura como possíveis precursores de movimentos estéticos e ideológicos: Manuel Antônio de Almeida (1831-1861), pré-realista, e Lima Barreto (1881-1922), prémodernista. ${ }^{18}$ Questão controversa, a periodização literária pode ser parcialmente explicada pela consideração de Afrânio Coutinho:

"Se há, portanto, época que se recusa a uma periodização precisa e a mostrar nitidez de fronteiras entre os movimentos, é o século XIX. Estes misturam-se, as figuras literárias nem sempre apresentam uma fisionomia nítida quanto ao colorido estético, o mais das vezes vestem roupagens diferentes no curso de sua evolução literária, quando não usam, no mesmo instante, os caracteres de escolas diversas ou opostas. Esse fenômeno que é geral, no Brasil torna-se mais corriqueiro, dadas as circunstâncias naturais de sua vida na época, e em virtude do atraso com que sempre repercutem entre nós os movimentos espirituais, e ainda porque as transformações aqui não se realizam organicamente, de dentro para fora, como resultado da própria evolução da consciência nacional, mas como reflexo de idéias-força de origem estrangeira."19

Quanto a Machado de Assis (1839 - 1908), já se observou que o escritor não parecia caber rigorosamente nos moldes convencionais realistas. Segundo Oscar D’ambrosio:

[seu] "fascínio consiste, em boa parte, na impossibilidade de classificá-lo facilmente em estilos de época. Sua arte resiste a enquadramentos rígidos, conseguindo, entre outros méritos, revelar profundas contradições da natureza humana e, simultaneamente, elaborar um quadro real e crítico da sociedade carioca de seu tempo.” (p. 110)

É curioso que os três autores tenham comungado uma infância humilde e que sua ascensão nas letras fosse amparada financeiramente pelos modestos rendimentos da carreira pública e as diversas atividades na imprensa. O emprego público serviu de lastro à produção de escritores que, apesar de portar estilos muito diferentes, apresentavam em comum o esmero de raros polígrafos: por talento, criaram obras literárias; por arte e profissão, registraram diariamente suas impressões na linguagem referencial do jornal; por força da necessidade, confeccionaram documentos prémoldados na repartição.

tempo. A esse respeito saliento os nomes de Antonio Candido e Alfredo Bosi, cujos estudos nortearam em boa parte as presentes análises.

${ }^{18}$ Para Massaud Moisés: "Lima Barreto constitui um elo de união entre o Realismo e o Modernismo. Escritor fronteiriço, o primeiro aspecto que nos chama a atenção diz respeito ao humor, um humor bem brasileiro, puxado à caricatura e mesmo à chalaça, que impregna as criaturas e as situações." (A literatura brasileira através dos textos, pp. 335-6)

${ }^{19}$ Introdução à literatura no Brasil.

20 “O desalienante realismo de Machado de Assis”. In: Arlenice Almeida et al. A supremacia do conto. 
O orçamento proveniente da ocupação de rotina fixa completava-se com atividades nas chamadas profissões liberais, principalmente no jornal. Antônio Luís

\section{Machado Neto constatou que:}

"A maioria de nossos escritores foi de polígrafos, como um reflexo, no plano intelectual, da pouca diferenciação que caracteriza a sociedade agrária e tradicional do subdesenvolvimento. Raros são os monógrafos, sendo, embora, mais numerosos aqueles que se mantiveram constantemente no terreno exclusivo da literatura, aí, perlustrando a prosa e o verso em seus diversos gêneros. Machado de Assis é um desses casos, pois no campo literário cultivou a poesia e a prosa e, nesse âmbito, o romance, o conto, a crônica, a crítica e o teatro. O mais freqüente era, porém, o médico, o bacharel, o militar ou o engenheiro que, além dos temas técnicos de sua especialização, versasse a política e a literatura, esta em numerosos gêneros de prosa e verso.” (p. 51) “A função pública, nela incluindo-se a maior parte dos que se dedicaram ao magistério, seria responsável pela subsistência de nossos intelectuais. Ela chegou, mesmo, a constituir um objetivo vital” (p. 84) ${ }^{21}$

Almeida, Machado e Barreto lograram publicar alguns de seus escritos com a imprensa de permeio - fato que revela os vínculos de cada um tanto com os sinuosos bastidores providos pelos homens que gerenciavam a máquina de notícias, quanto perante o público leitor de romances. Carmen Figueiredo chamou a atenção para o intrincado jogo inerente às relações entre os homens de letras e a imprensa, no século XIX:

“À medida que se comercializa, a partir do século XIX, a imprensa se torna manipulável, pois se estabelece a correlação entre a venda da parte de anúncios e a venda da parte redacional.” (p. 29) "A pessoa do editor canaliza todo o fascínio e poder que o jornal exerce sobre seus leitores e, especialmente, sobre os próprios jornalistas (...) sua presença manipula homens que fazem objeto de troca a melhor parte de seus sentimentos e seus pensamentos, a ponto de se anularem como produtores de idéias.” (p. 39) "Através da análise da personagem Isaías Caminha, Lima Barreto põe a descoberto a existência cada vez mais ampla de zonas ambíguas na ordem vigente, em que não há condições de se determinar o certo, o errado, o justo, o injusto, o honesto, o desonesto etc. Aponta, ainda, que a prática comum passa a ser a de burlar individualmente as regras, utilizando-se até mesmo das instituições para esse fim.” (p. 44) ${ }^{22}$

Descontado o tom mais sóbrio de Machado, há que se lembrar que Antônio de Almeida e Lima Barreto são reconhecidos por nossos historiadores literários por terem tratado a forma artística através de uma linguagem mais próxima da modalidade popular $^{23}$. O critério de aproximar, via literatura, o formalismo estrito convencional da

\footnotetext{
${ }^{21}$ Estrutura social da república das letras: sociologia da vida intelectual brasileira, 1870-1930. Essa também é a opinião de Sérgio Miceli, vide o capítulo: "A expansão do mercado do livro e a gênese de um grupo de romancistas profissionais” In: __. Intelectuais e classe dirigente no Brasil (1920 - 1945). São Paulo/Rio de Janeiro: Difel, 1979. É oportuno o questionamento de Raúl Castagnino: “caberia perguntar se não houvesse existido um Mecenas ou um Augusto, teriam escrito como o fizeram um Horácio, um Virgílio. (....) O escritor de idades passadas podia viver exclusivamente das letras e a elas consagrado, se possuísse fortuna pessoal, se o protegesse um poderoso ou se estivesse refugiado no religioso.” (Análise literária, p. 76)

${ }^{22}$ Lima Barreto e o fim do sonho republicano.

${ }^{23}$ Para Oliveira Lima, "Lima Barreto procura felizmente não escrever bonito: antes, mil vezes antes, singelo, familiar mesmo, do que pernóstico. (...) como Manuel Antônio de Almeida, se contenta, sem
} 
linguagem oral poderia ser explicitado pelo longo período em exercício nos jornais. José Ramos Tinhorão assinalou que:

"O romance moderno, que começara no século XVIII adotando a forma da troca de cartas entre os personagens, permitindo a configurar as histórias sem a participação do autor (...) passa com o individualismo romântico a ter na figura do autor o Deus todo-poderoso das histórias. O autor, e não a vida social real, é o senhor dos enredos (...) De fato, e embora a maioria dos historiadores da literatura brasileira não chegue a mencionar essa circunstância, é do romance de folhetim que se originam as principais características da técnica do romance no Brasil: a constante intervenção do autor no desenrolar das histórias (inclusive dirigindo-se aos leitores em tom de conversa); a extrema complicação dos enredos, num desdobramento linear de quadros sem preocupação com a verossimilhança; a finalização de cada capítulo em clima de suspense, e a surpresa da retomada de personagens e situações anteriores em conexão inesperada com ações atuais” (pp. 27-8) ${ }^{24}$

Foram escritores que manifestaram poderosas doses de humor, empregando a sátira como panfleto social, mais explicitamente nos romances e crônicas de Lima Barreto.

\section{II}

Apesar de os protagonistas (Leonardo-filho versus Vidigal; Simão contra Porfírio; Gonzaga e Augusto versus Xisto) fugirem à fixidez, não se deve desprezar a tendência à tipificação, anunciada em Almeida, bem acabada em Machado e escrachada em Lima. É que a configuração do tipo, principalmente em Almeida e Lima, associa-se ao gosto pela descrição da cidade e das coisas datadas, bem como demarca as limitações das próprias figuras. Segundo Alfredo Bosi:

"Estreitando o horizonte das personagens e da sua interação nos limites de uma factualidade que a ciência reduz às suas categorias, o romancista acaba recorrendo com alta freqüência ao tipo e à situação típica: ambos, enquanto síntese do normal e do inteligível, prestam-se docilmente a compor o romance que se deseja imune a tentações da fantasia. E de fato, a configuração do típico foi uma conquista do Realismo, um progresso da consciência estética em face do arbítrio a que o subjetivismo levava o escritor romântico a quem nada impedia de engendrar criaturas exóticas e enredos inverossímeis” (p. 170) ${ }^{25}$

esforços de originalidade, em ser ele próprio" ("Policarpo Quaresma”* In: Triste fim de Policarpo Quaresma, 1956, p. 10. *Publicada originalmente no Jornal O Estado de São Paulo, em 13 de novembro de 1916). Segundo Luiz Beltrão: "Foi pelos botequins e cafés de Paris, pelos clubes literários de Londres, pelos claustros dos agostinhos, beneditinos e franciscanos (nos quais se refugiavam os corpos de nouvellistes) que, caindo como uma pedra na superfície de um lago, o jornalismo, ampliando em círculos excêntricos a sua penetração, lançou-se à conquista da rua, isto é, do povo, das massas." (Iniciação à filosofia do jornalismo, p. 92)

${ }^{24}$ Os romances em folhetins no Brasil: de 1830 à atualidade.

${ }^{25}$ História concisa da literatura brasileira. Para Bakhtin: “O tipo tanto está profundamente entrelaçado com o mundo que o rodeia (com o ambiente dos objetos) quanto é representado como condicionado por esse mundo em todos os seus momentos; ele é o elemento necessário de um dado ambiente (não é um todo mas somente parte de um todo).” (Estética da criação verbal, p. 169) 
Além de parodiar os conteúdos convencionais, na forma, Almeida e Barreto valeram-se corajosamente da subversão lingüística. A esse respeito, Pereira da Silva chamou a atenção para o relevante papel do segundo:

"Na verdade antecipou-se à Semana de Arte Moderna de São Paulo ou de qualquer outro Estado menos bairrista. Antes dele, que outro romancista de sua importância já havia se libertado do jugo lusitano, mais vigilante que o próprio vernáculo imposto aos clássicos?” (p. 31) ${ }^{26}$

Do ponto de vista cronológico, as narrativas abrangem o intervalo que antecedeu a chegada da corte e súditos ao Brasil - número que variava de dez a quinze mil bajuladores, segundo os historiadores - e a imigração maciça de europeus, intensificada a partir dos anos iniciais do século seguinte.

O romance de Almeida e a novela de Machado fazem reparos no regime de governo, o Vice-Reinado; Lima Barreto situa a biografia sobre Gonzaga de Sá imediatamente após a transição do Segundo Império para a República. Parece curioso que Machado tenha localizado a vinda do médico alienista como evento imediatamente anterior à vinda da família real, em 1808. A data coincide com o marco que levou Manuel Antônio de Almeida a deslocar o eixo temporal para contar as suas Memórias. Do palco para os bastidores da história. De acordo com Boris Fausto:

“O príncipe Dom João, que regia o reino desde 1792 quando sua mãe Dona Maria fora declarada louca, decidiu-se em poucos dias pela transferência da Corte para o Brasil. Entre 25 e 27 de novembro de 1807, cerca de 10 mil a 15 mil pessoas embarcaram em navios portugueses rumo ao Brasil, sob proteção da frota inglesa. Todo um aparelho burocrático vinha para a Colônia: ministros, conselheiros, juízes da Corte Suprema, funcionários do Tesouro, patentes do Exército e da Marinha, membros do alto clero. Seguiam também o tesouro real, os arquivos do governo, uma máquina impressora e várias bibliotecas que seriam a base da Biblioteca Nacional do Rio de Janeiro. (...)” (p. 66) ${ }^{27}$

Três escritores de origem humilde, forçosamente adaptados à sociedade de um país francamente provinciano. Vivendo em épocas cruciais de nossa formação sóciocultural, foram artistas que configuraram em intervalos aproximados uma gradativa escala, ora de auto-afirmação nacional ora de questionamento aberto de nossa cultura.

Diferentemente dos autores com que dividiam o crédito das letras em seu tempo, forjaram episódios não só para a mitificação de tipos ou a glorificação de eventos, mas visando a autocrítica de nós mesmos, ultrapassando por vezes os domínios da ficção. ${ }^{28}$

\footnotetext{
${ }^{26}$ Lima Barreto - escritor maldito.

${ }^{27}$ História concisa do Brasil.

${ }^{28}$ Para Alfredo Bosi: “faltava a Macedo para ser um memorialista de valor o que sobejava a Manuel Antônio de Almeida - o senso vivo do ridículo em que as convenções enredam o homem comum. (...) Em Macedo a veracidade dos costumes fluminenses aparece distorcida pela cumplicidade tácita com a leitora que quer ora rir, ora chorar, de onde resulta um realismo de segunda mão, não raro rasteiro e lamuriento. Em Manuel Antônio, o compromisso é mais alto e legítimo, porque se faz entre o relato de um momento
} 
Manuel Antônio de Almeida, Machado de Assis e Lima Barreto reagiram de formas bem variadas aos controversos avanços e recuos de nossa sociedade em perene formação, através de alegorias nem sempre evidentes; pelo tom de aparente puro divertimento, ou ainda por meio de pseudo-teorias comportamentais (científicas ou de cunho sociológico) que quebrassem a expectativa não só do leitor de sua época, mas questionassem os costumeiros discursos elegantes.

Com um pé entre o Romantismo e o Realismo, Manuel Antônio de Almeida, tipógrafo de carreira, seria um de nossos primeiros escritores a converter a matéria de jornal em romance, vide as próprias Memórias de um sargento de milícias - publicadas em dois volumes, entre 1854 e 1855, antecedidas pela divulgação integral nos folhetins. Lembre-se que a Imprensa havia sido instalada recentemente, no país.

"O século XVII vê surgir a imprensa por toda a Europa civilizada e na Nova Inglaterra (...) No Brasil, apesar de não termos tido imprensa senão às vésperas do Ipiranga, nem por isso o colono português integrado na nossa vida, ou o nativo, deixou de praticar o jornalismo. A exemplo de outros povos, apelou para a informação e a sátira verbal, para o pasquim e para a folha volante. Nos tempos mais remotos da colonização, era dos púlpitos das igrejas que se utilizavam os letrados oradores sacros para transmitir notícias e conselhos à comunidade.” (p. 38) ${ }^{29}$

Argutos observadores dos comportamentos humanos, evidenciaram certas configurações dos tipos sociais. Machado talvez seja o mais refinado analista de almas, dentre nossos literatos; Lima, despojado do cinismo de Machado, elaborou personagens caricatas, marcadas - às vezes em prejuízo do enredo - pelo estrito apego ao modus faciendi.

Como um dos pré-requisitos do jornalista-cronista reside na competência de pintar em breves traços determinados "tiques” sociais, Manuel, Machado e Barreto fizeram uso de suas habilidades, enquanto cronistas, para transpor para a ficção determinados comportamentos através de personagens indubitavelmente marcantes.

Da representação literária ao mercado leitor. Por aqui, periferia cultural, os livros com freqüência não se ligam imediatamente aos conceitos que divulgam ou aos ideais que sugerem. Raros os que se aventuraram a explicitar, sobretudo no terreno da

histórico (o Rio sob D. João VI) e uma visão desenganada da existência, fonte do humor difuso no seu único romance” (História concisa da literatura brasileira, pp. 131-2).

${ }^{29}$ Luiz Beltrão. Iniciação à filosofia do jornalismo. Segundo Boris Fausto: “A expulsão da Ordem abriu um vazio no já pobre ensino da Colônia. A Coroa portuguesa, ao contrário da espanhola, temia a formação na própria Colônia de uma elite letrada. Já no século XVI, a Espanha criou na América várias Universidades (...) Nada disso ocorreu na América lusa, durante todo o período colonial. Aliás, praticamente a mesma coisa aconteceu com a imprensa, que surgiu nas maiores cidades coloniais da América espanhola também no século XVI. Enquanto isso, ressalvando-se uma oficina gráfica aberta em 1747 no Rio de Janeiro e logo depois fechada por ordem real, a imprensa no Brasil só nasceria no século XIX, com a vinda de Dom João VI.” (História do Brasil, pp. 111-12). 
ficção, certas graves questões ligadas à nossa constituição, tocada desde sempre ao largo e a trote apressado.

De todo modo, a vinda da família real para o Brasil possibilitou com todos os reveses a efetiva disseminação da arte literária, precedida pela atuação dos escritores em atividades direta ou indiretamente relacionadas aos veículos de leitura diária, viabilizados pela criação de estabelecimentos destinados à impressão de panfletos, folhetins e jornais - reservados ao reduzido número de leitores, os alfabetizados.

Ao desenhar os costumes em acordo com a época em que se passam as narrativas, Almeida, Machado e Lima Barreto tratam das novas maneiras, dos gestos imitados - aqui, ainda mais afetados, já que chegam para suprir uma lacuna nos costumes. São ferramentas que auxiliam a converter o jeito de lá (Europa) no multiforme trejeito brasileiro.

Leonardo, Simão e Gonzaga teriam algo de atípico. Por não expressar o que a literatura convencional esperava? Nenhum dos protagonistas serve a caracterizar puramente o traço idealizante (romântico) ou o desmistificador (naturalista) do brasileiro. Seria empobrecedor, portanto, interpretá-los apenas como tipos prontos e acabados, embora certas peculiaridades os aproximem de caricaturas: o esperto, ainda que sem a malícia de um velhaco; o douto, embora sem estar exclusivamente voltado ao utilitarismo positivista; e o revoltado, apesar de desprovido de voz.

O êxito de tais figuras se deve principalmente ao seu escorregão comportamental, vide a flexibilidade com que estipulam, encarnam ou desafiam leis e teorias. A combinação de elementos de tipicidade e atipicidade pode ser percebida na trajetória do malandro sem ambição; na obsessão pela sanidade por parte do insano; no fracasso do sábio.

Protagonistas que margeiam o Império brasileiro, estão em constante movimento, traduzindo a idéia de que viver nas ruas favorece certas mudanças de postura e pensamento. É de forma dinâmica, sem parada, que se processam a malandragem de Leonardo-filho, a reformulação das teorias bacamartianas e a reflexão mordaz de Gonzaga de Sá.

\section{III}

Se lidas em paralelo, determinadas mensagens se somam e tais livros, desse ponto de vista, parecem reedições de um mesmo recado reformulado de tempos em tempos: o sucesso pessoal, por aqui, também pode acontecer por acaso ou acidente, 
mediante compadrios, caprichos do destino ou em meio a um tenebroso mar de contendas: o principal ponto de articulação comum à trajetória dos três heróis ${ }^{30}$.

Aproveitadores e flagelados não ficam tão distantes. Uns e outros carregam a semente da potência sem controle ou, numa chave invertida, da impotência por falta de oportunidade de controlar. Se Maria, a tia de Luizinha (Milícias) vive das demandas judiciais, Porfírio, aquele que enfrenta o retórico de classe Bacamarte, tinha lá suas pendengas com outro rival, o barbeiro Pina (O Alienista).

Já Gonzaga e Augusto (Gonzaga de Sá) dispõem de tempo de sobra para fazer reparos nos pensamentos curtos e gestos demorados - labor sem energia? -, de seus colegas de repartição. Estes, aliás, revelam-se ainda mais medíocres quando se metem a questionar, com muita pompa e pouca consistência, assuntos de pouca serventia.

Como se comportaria Leonardo-filho se, desde o princípio de sua vida estivesse sob a guarda de Vidigal? E Bacamarte, sem o poderio outorgado pelo Reino que ele mesmo representa na província? Quais seriam os procedimentos de Gonzaga de Sá, se ocupasse um cargo de maior circulação entre os homens da alta roda que tanto questionava? Não são as circunstâncias que determinam seus atos e discursos?

Afinal, os trejeitos de um malandro, a mania classificatória de um médico e a revolta de um sexagenário relativamente bem posto foram representados por que razões? O fato é que nos três casos parece configurada uma intencional confusão de papéis, levando-se em conta também o status ${ }^{31}$ do jovem, do maduro e do idoso.

Ora, espera-se do jovem que se aventure; do maduro, que seja determinado, objetivo; do idoso, que pondere e deixe exemplos. Não poderiam Leonardo, Simão e Gonzaga personificar três estágios da história do difícil amadurecimento do Brasil? O jovem malandro, o médico sabichão e o velho ranzinza, no fundo, não revelam as três idades do país, fosse Colônia, Império ou República?

\footnotetext{
${ }^{30}$ Os heróis estão lá para denunciar, enfrentando as convenções literárias em cada época. Tal ruptura ideológica, fugindo à orientação estética a que cada um dos escritores se filiava pode ser explicada em parte por Auerbach: "A civilização burguesa se baseia no liberalismo; o princípio da tolerância, da livre troca de idéias, do livre jogo das forças, é de tal modo inseparável da origem e da essência mesma dessa civilização que esta se via forçada a permitir a expressão de idéias que minavam sua própria vida e a tomar parte em sua discussão.” (Introdução aos estudos literários, p. 239)

${ }^{31}$ Para E. T. Hiller: "Saber qual é o seu lugar, ou qual deve ser, é o primeiro passo de preparação para a vida. Por força de tal atribuição de status, as pessoas não somente têm seu curso predeterminado, e são impelidas para ele, mas também têm que carregar a etiqueta, a marca de sua classificação, por exemplo, (...) tipos diferentes de roupa e habitação." "“Características do status social” In: Homem e sociedade, p. 80)
} 


\title{
Drama em três atos
}

\begin{abstract}
"l'art du poète comique est de nous faire si bien connaître ce vice [tragique], de nous introduire, nous spectateurs, à tel point dans son intimité, que nous finissons par obtenir de lui quelques fils de la marionette dont il jue; nous en jouons alors à notre tour; une partie de notre plaisir vient de là.” (Henri Bergson) ${ }^{32}$
\end{abstract}

Neste trabalho, a primeira análise se propõe a resgatar leituras de estudiosos, sugerindo algumas pistas sobre o folhetim-romance de Manuel Antônio de Almeida. O segundo capítulo atualiza uma interpretação sobre a novela de Machado de Assis. ${ }^{33} \mathrm{O}$ terceiro estudo se detém no derradeiro e menos extenso romance de Lima Barreto sabidamente um dos menos abordados pela crítica. Em "Bastidores” são retomados alguns dos temas anunciados no "Proscênio".

O tom pseudo-referencial ajusta-se à paródia de certos períodos de nossa história. Quanto aos homens, são reconstituídos sob a forma de personagens em épocas distintas, mas similarmente influenciadas pela arbitrária administração portuguesa, cuja autoridade era exercida com base em formas de violência ${ }^{34}$ e asseverada na repetição: ordem em forma de burocracia.

O fato é que nesses exemplares de mandonismo, dominação e impotência, impera o favorecimento pessoal, com direito a patéticas cenas de contenda, brigas de palanque e rixas na repartição pública. As lutas pelo poder começam nas palavras, sejam elas proferidas de baixo, de cima ou dos bastidores. Determinados episódios chamam a atenção para a face lúdica de certas matérias, notadamente as sérias.

O poder e seus protocolos de ascensão, manutenção e declínio são tópicos que se articulam. Os arbítrios de um major escorregadio; a autonomia de um médico, doutor e símio; a resignação de um sábio. A força dos novos regimes (Império, República, Nova República) cuja prepotência nada muda.

\footnotetext{
${ }^{32}$ Le rire, p. 12 (* “a arte do poeta cômico é de nos fazer conhecer tão bem esse vício (trágico), de nos introduzir, a nós espectadores, a tal ponto em sua intimidade, que acabamos por dele obter alguns fios da marionete com que joga; então, nós jogamos em nosso turno; uma parte de nosso prazer advém disso.”)

${ }^{33}$ Em estudo anterior (O Alienista: a teoria dos contrastes em Machado de Assis. São Paulo: Reis, 2005), O Alienista foi abordado como "conto", conforme a orientação de alguns críticos ("conto de idéia", segundo Massaud Moisés. A criação literária, pp. 141-2). Parece produtivo rever tal classificação, considerando as dimensões e demais características dessa narrativa, distantes dos padrões vistos nos contos machadianos. Raymundo Magalhães e Alfredo Bosi aceitam a denominação "novela”.

${ }^{34}$ José Guilherme Merquior percebeu traços de violência extrema nas relações entre as classes, em várias obras de Machado, particularmente em Memórias póstumas de Brás Cubas. Sua análise encontraria eco nas interpretações de Roberto Schwarz que, nos anos 70, compôs uma farsa (A lata de lixo da história) baseada no enredo de $O$ Alienista, abordando o preconceito racial (escravidão) e a violência militar (ditadura).
} 
Aos impotentes sobram os esbarrões com os potentes mantenedores que manejam com destreza a suposta ordem, seja policial, política e/ou do equilíbrio (no caso, mental) - todos com o reforço da burocracia cujo peso se sente, mas não se distingue.

Vidigal age em nome da ordem sem lei; Bacamarte, em razão da busca de certa uniformidade de comportamento, calcada em critérios sem firmeza que contrastam com o discurso pseudocientífico e seu magnificente porte de médico. Em Gonzaga de Sá, o poder é observado por detrás, dos bastidores: do ponto de vista do apático Gonzaga e de seu amigo-discípulo Augusto Machado.

Se nas Memórias de um sargento de milícias o poder está vinculado à potência dos milicianos ligados aos mandos e desmandos da administração portuguesa, em $O$ Alienista a fórmula é parcialmente aplicada. Recorde-se que o tempo em que se passam as aventuras máximas na vida de Itaguaí antecede em poucos anos aquele dos eventos narrados no romance de Manuel Antônio de Almeida.

Em O Alienista também encontramos barbeiros, dragões e um mandão - não na pele de major da corte, mas médico cosmopolita que, de forma similar a Vidigal, tem por força não só do hábito, trancafiar supostas vítimas de síndromes morais. Diferentemente do que acontece no romance de Almeida, na novela machadiana, as autoridades máximas estão em luta franca. Cada um tem suas razões para alçar o poder político. $^{35}$ Às algazarras provocadas pelo médico, cioso de uma nova ordem de cognome científico, mal rechaçada pelos populares e dragões, o intermédio escorregadio do padre Lopes. As ações poderiam igualmente ser aproximadas daquelas que movem as figuras e justificam o andamento também rocambolesco das Memórias de um Sargento de Milícias.

Nesse romance, Leonardo-filho, herdeiro de uma incipiente classe média, é criado por um barbeiro e uma parteira. Está o tempo todo em disputa com os dogmas vigentes, quase por acaso e, se pouco permanece em casa, é porque só vive na rua. $\mathrm{Na}$ procissão, ${ }^{36}$ acompanha os desordeiros; na barbearia, espanta os fregueses; na sacristia, enfrenta o padre com manias das carnes da Cigana; na ucharia, engraça-se com a mulher do superior hierárquico; e mesmo na função de guarda, desafia mais de uma vez o

\footnotetext{
${ }^{35}$ Conforme Fernando Henrique Cardoso, historicamente "cidade e política nasceram, na tradição ocidental, como conceitos e realidades inter-relacionadas. De resto, etimologicamente as ligações são claras: civitas e polis são as raízes em distintos idiomas para expressar, ao mesmo tempo, um modo de habitar e uma forma de participar: civismo e política.” (Autoritarismo e democratização, p. 135).

${ }^{36}$ Segundo DaMatta: "nas procissões a mediação entre o povo e o santo é realizada pelas autoridades (que carregam o santo no seu andor e estão mais próximas dele).” (Op. Cit., p. 66).
} 
máximo reduto de poder da cidade - o já mais complacente Major (maior) Vidigal.

O poder é disputado pelo avesso, num e noutro caso. Mas, enquanto no romance a peraltice de Leonardo-filho enfrenta a ordem de forma escorregadia, refletindo talvez a imaturidade do país (“Um brasileiro”), em O Alienista as disputas são necessariamente explícitas, mesmo porque públicas. Fazem de Itaguaí verdadeiro palco onde ciência, religião, crendices populares, poderes reais e outras relativas sabedorias se enfrentam abertamente. Daí a ênfase do narrador nos discursos dos hábeis oradores: médico, padre, vereadores e ambos os barbeiros.

Nas Memórias, o avesso integra o processo romanesco, a fatura literária. Cada capítulo parece refém das artimanhas do traquinas: sujeito que ludibria qualquer instituição vigente (costumes/tradição; crenças/religião; autoridade/Vidigal), manipulando inclusive o leitor, capaz de torcer para que as peraltices de Leonardo-filho surtam o efeito de burlar a lei, os poderes judiciário e executivo encarnados pelo major.

Como na novela machadiana, a anedota de Almeida trata zombeteiramente as coisas sérias, mas, no romance de Lima Barreto, acontece o contrário: o que poderia servir ao cômico é motivo estrito para graves reflexões. As figuras se deparam com a hierarquia e as explícitas relações de favor. Cabem as palavras de Maria Sylvia de Carvalho Franco:

"o fabricar de lealdades e fidelidades através de um processo cumulativo de recíprocos encargos e favores promovia, sucessivamente, a eliminação completa da possibilidade de um existir autônomo. Os efeitos desse processo não param no nível da orientação da conduta, cancelando a racionalidade mínima que implica na representação subjetiva de motivos e de fins, eles atingem até a própria consciência do mundo social, impossível de ser concebido senão mediante o prisma formado pela encarnação do poder: este transfigura a realidade social, convertendo-a nas formas objetivadas da existência daquele que é ideado como superior, e plasma as categorias através das quais ela é conhecida, confinando-as a imagens que não podem transcender essa mesma situação vital particular, personificada e alheia.” (p. 87) ${ }^{37}$

Em O Alienista, o avesso não está somente no apelo rocambolesco (o que, como ficou dito, lembra o enredo de Memórias de um Sargento de Milícias), mas nas partes em constante litígio: vereadores vira-casaca; barbeiros com sede de poder e nomeada e um médico, cujo bem feito à humanidade beira o desumano. Teorias sem propósito e ações com base nas palavras: discursos de oratória barata. ${ }^{38}$

\footnotetext{
${ }^{37}$ Homens livres na ordem escravocrata. Nas palavras de Roberto Schwarz: "O favor, ponto por ponto, pratica a dependência da pessoa, a exceção à regra, a cultura interessada, remuneração e serviços pessoais.” (Ao vencedor as batatas, p. 16).

38 “(...) vamos encontrar na obra de ficção machadiana políticos, jornalistas, homens de letras, oradores de salão etc, cuja mediocridade ridícula é por tal meio configurada: entre a realidade e si próprios põem de permeio este anteparo de expressões convencionais, que lhes permite tão só percorrer os caminhos já explorados por outros, protegendo-os assim contra qualquer surpresa, tanto é certo que o medíocre é por
} 
Estruturado de um ponto de vista diverso, é o avesso do poder que motiva o romance de Lima Barreto. Gonzaga de Sá é uma historieta que concentra sua própria estrutura (doze capítulos; doze meses de contato entre Augusto e o amigo falecido?) em diálogos que têm por função desmistificar certos costumes locais, principalmente os importados.

A ideologia alheia também desfila no vestir-se: metonímia dos modos e piadas sem-graça dos arrivistas cariocas sem idéia ou pele própria. Essa, aliás, parece ser uma das razões para a necessidade de isolamento de Gonzaga de Sá. Daí os constantes passeios do sexagenário frente ao mar, as leituras em casa, a caminhada solitária, e alguns intervalos para os raros amigos com que esbarra nos cafés.

Na crônica romanceada de Almeida, o gosto de Dona Maria pelo mandado judicial recorda os longos prazos para a resolução de demandas "no tempo do rei”.

Na novela de Machado, as picuinhas entre os vereadores estão no mesmo nível das contendas entre os dois barbeiros. Os subsídios para a construção da Casa Verde e a dispendiosa viagem de Evarista Mascarenhas - a primeira-dama da vila - e sua numerosa comitiva ao Rio de Janeiro lembram, em menor escala, certos feitos no opulento reinado de D. João VI e seus vice-reis, bem instalados por aqui. ${ }^{39}$

No romance de Lima Barreto, o hábito de abrir e fechar gavetas por parte de um funcionário da repartição não só demonstra o tempo ocioso do servidor público; ilustra a mesmice das coisas na virada sem traumas do Império para a República: passa-tempo oficial e remunerado.

A disposição para as mudanças remete ao fetiche embutido na demanda de autoridade dos indivíduos: subverter sem saber por que (Leonardo); curar não se sabe do quê (Bacamarte). Já Lima Barreto também chega para desmistificar certas vaidades mundanas, mas desprovido da anedota ou o requinte das meias palavras. Antonio Candido sintetizou bem as razões de seu estilo:

“ele canalizou a própria vida para a literatura, que a absorveu e tomou o seu lugar; e esta doação de si mesmo atrapalhou-o paradoxalmente a ver a literatura como arte. (...) Outro traço básico da sua escrita é com efeito o desejo de oposição contra as categorias comprometidas do seu tempo - o 'bonito', o 'elegante', o 'profundo' -, que rejeitava de cambulhada com o bem-

natureza conservador, mesmo quando assume atitudes de vanguarda.” (Maria Nazaré Soares. Machado de Assis e a análise da expressão, p. 25).

${ }^{39}$ Conforme Eduardo Tourinho: "De 5 de abril de 1779 a 6 de junho de 1790, governou o vice-rei D. Luís de Vasconcelos e Sousa - da ilustre casa de Castelo Melhor. Nas 'Instruções' fornecidas pela Metrópole, era-lhe recomendado zelar pela religião e pela justa distribuição da justiça; incentivar a arrecadação dos tributos, a cultura das terras, o comércio e a navegação. E, sobretudo, não descuidar do policiamento do Rio de Janeiro. (...) Muito embelezou a cidade. Coube-lhe criar - através de mestre Valentim - o Passeio Público. (...) Encerrou sua notável administração entre aperturas financeiras." (Revelação do Rio de Janeiro, pp. 214-6). 
feito e o bem-acabado, como quem nega a face da iniqüidade na literatura e por isso quer mostrar o real desmascarado. (...) No combate ao discurso de corte acadêmico, ficou, por assim dizer, no pólo oposto ao de Raul Pompéia” (p. 41)

Outro dado comum às três obras são as condições de relativo isolamento das personagens principais. A bandalheira máxima, exclusiva de Leonardo-filho, o autoexílio de Simão Bacamarte e a solidão frente à mediocridade coletiva, de Gonzaga de Sá. Figuras incompatíveis frente às convenções sociais: um estorva por divertimento; outro subverte por meio da autoridade; o terceiro a ela se submete com resignação.

A visão do malandro acontece por entre. A malandragem, curiosamente, não atrapalha sua relativa subida na vida, através dos meandros e conchavos em mãos alheias. Sua ascensão faz de Memórias de um sargento de milícias um “bildungsroman” às avessas, já que lá não há lugar para a edificação ou o sucesso por mérito próprio.

Bacamarte é auto-isolado pelo saber exclusivista: sua visão é de cima, além-mar, autoritária.

Gonzaga de Sá está apartado dos demais por suas convicções: a sua visão é de baixo. Revela-se no inconformismo, pois questiona a tosca sede de ascensão dos homens.

Leonardo, Simão e Gonzaga são contrapesos às instituições fixas. Almeida disfarça, quando não realça, o desajustamento da personagem central no descompassado tom anedótico-histórico. Machado ilustra a máxima autoridade do médico em sua reclusão. Lima equilibra doses de sapiência nas pernas de um atípico andarilho, cuja lucidez não condiz com a tacanha obsessão alheia pelo carreirismo, desejosos de fama, autoridade ou mando. ${ }^{41}$

Ainda que encaradas como meras anedotas, seriam ferramentas a desmoralizar as instituições luso-brasileiras. A literatura brinca ou embrutece frente aos fatos históricos e a anomia, a meio-caminho de ser oficializada. De acordo com Raymundo Faoro:

"Interfere, entre a metrópole e a colônia oficial, larga parcela de arbítrio do setor privado, que, desta sorte, usurpa funções públicas. Este um efeito inesperado do colegialismo: ao limitar, em proveito de uma categoria social, a autoridade real e ministerial, abre uma faixa de governo aos particulares e aos distantes e abandonados oficiais da Coroa. Daí não se originou, todavia, um

\footnotetext{
40 “Os olhos, a barca e o espelho” In: A educação pela noite \& outros ensaios.

41 Já dizia Gilberto Freyre: “a tradição conservadora no Brasil sempre se tem sustentado do sadismo do mando, disfarçado em ‘princípio de Autoridade’ ou ‘defesa da Ordem’. Entre essas duas místicas - a da Ordem e a da Liberdade, a da Autoridade e a da Democracia - é que se vem equilibrando entre nós a vida política, precocemente saída do regime de senhores e escravos.” (Casa Grande \& Senzala, p. 52. [Grifo meu]). Definição de “mando” registrada por Bobbio: “De acordo com Wrigth Mills e Gerth, toda situação onde, "por causa de quem está guiando, os que estão sendo guiados agem e sentem de forma diferente do modo como agiriam e sentiriam se não estivessem sendo guiados’.” (Dicionário de política, pp. 715-6).
} 
campo de self-government local, ou do exercício de liberdades municipais. Cria-se um governo, ao contrário, sem lei e sem obediência, à margem do controle, inculcando ao setor público a discrição, a violência, o desrespeito ao direito. Privatismo e arbítrio se confundem numa conduta de burla à autoridade, perdida esta na ineficiência. Este descompasso cobrirá, por muitos séculos, o exercício privado de funções públicas e o exercício público de atribuições não legais. O déspota colonial e o potentado privado têm aí suas origens, origens que o tempo consolidará.” (p. 210) ${ }^{42}$

Na política ou no militarismo, na ciência e nas tênues relações de amizade, os caminhos de acesso aos cargos, postos, patrimônios e funções são constituídos por degraus sinuosos e estreitos. Muitos sujeitos medíocres foram considerados inteligentes porque desbravaram os bastidores. O labirinto exige aptidão. Mas ser hábil é prova de inteligência?

Os escritores em questão criaram marcantes personagens que, além de escapar aos padrões romanescos de seu tempo, fugiam dos estereótipos. Permitiam questionar as convenções sociais, bronqueando lúdica ou sobriamente diante do senso de hierarquia e o lastro burocrático, operados sem muita parcimônia entre nós.

\section{Literatura como remate de males}

A colonização do Brasil esteve profundamente ligada à irrupção dos centros urbanos: verdadeiros pólos de captação, por assim dizer, de gestos e modos de dizer de extração européia. Povoados, vilas e cidades constituíram o cenário que vinha associado a alguns grupos sociais (proprietários de terras, banqueiros e comerciantes; assalariados, agregados e escravos), sob o olhar algo complacente da Casa Paroquial e das sentinelas Reais.

Para estabelecer o drama, o diálogo. Mas não a conversa envolvendo a troca de palavreados e gestos convenientes dos convivas nos salões, entre refeições e brindes. Almeida, Machado e Lima fogem à convenção literária também porque nas obras de outros escritores o diálogo que se estabelecia nos espaços domésticos ou públicos envolvia figuras de condições similares, favorecendo o contato entre proprietários e comensais sem abalo profundo das relações interpessoais e da estrutura sócioeconômica.

Interessava aos "romancistas da cidade" que os espaços fossem públicos, preenchidos por figuras contrastantes social, cultural e economicamente, porque viver em coletividade favoreceria os contatos mais imediatos e espontâneos entre homens dos

\footnotetext{
${ }^{42}$ Os donos do poder.
} 
setores sociais mais diversificados e, naturalmente, o confronto ideológico ${ }^{43}$.

Cenário por excelência de nossa política e produção cultural, da chegada da família real até a virada do Império para a República (séculos XIX e XX), a cidade do Rio de Janeiro converte-se, em sua ficção, num dos motivos mais bem ajustados para ambientar relações humanas conflitantes. Aliás, durante os treze anos de permanência da Corte no Brasil, aconteceu uma espécie de polimento de uma parcela de nossos habitantes, ${ }^{44}$ cujos modos afetados serviram principalmente como índice de distinção social: parecer europeu era ser brasileiro.

Por isso, na ficção, em lugar dos elogios à natureza, o ambiente urbano: pano de fundo de diversas obras, notadamente a partir do Romantismo, reavivado no Realismo, estendendo-se até a produção barretiana, realista modernista.

Em Memórias de um sargento de milícias, os espaços ilustram o intenso tráfego das personagens. Servem como elemento episódico: ambientam as festas e cerimônias de representatividade religiosa ${ }^{45}$, assim como proporcionam as diversas estripulias de Leonardo-filho e as diligências de Vidigal. As festas de que o jovem participa se caracterizam pela indistinção entre as classes sociais. Segundo Gilda de Mello e Souza, no século XIX:

“A festa (...) é a vida de exceção. Ela é principalmente aquele 'ponto de transição entre a vida real e o mundo da arte', de que fala Burckhardt. (...) A festa era, para uma sociedade deste tipo, mais que para qualquer outra, a ruptura na rigidez dos costumes. (...) arremessava os seres nas remotas regiões da fantasia onde, livres temporariamente das interdições e da vigilância rigorosa, homens e mulheres se abandonavam ao ritmo de suas tendências.” (pp. 145-6) ${ }^{46}$

Ao papel dessas comemorações é aplicável a tese de Roberto DaMatta, com vistas ao Carnaval:

"No carnaval, deixamos de lado nossa sociedade hierarquizada e repressiva, e ensaiamos viver com mais liberdade e individualidade. (...) uma nação de milhões de habitantes, um país industrializado, capitalista e na virada do século, permite que os 'pobres' virem 'ricos' durante

\footnotetext{
${ }^{43}$ A esse respeito, Mário de Andrade observou que Leonardo-filho: "Não falará umas dez frases sequer, num livro farto de dialogação, os outros falam por ele" (Aspectos da literatura brasileira, p. 135)

${ }^{44}$ Segundo Ruben Oliven, O Rio de Janeiro "se tornou uma cidade cosmopolita na qual as pessoas mais abastadas tentavam se comportar de uma maneira que elas supunham ser européia. Lá, mais fortemente, a difusão cultural do gênero de vida burguês, eminentemente urbano, começou a se desenvolver entre as classes altas. Outras cidades eram menores e a vida nelas era bastante simples quando comparada com a capital.” (Urbanização e mudança social no Brasil, p. 58)

45 "um Estado novo tem necessidade de todo o tipo de figuras emblemáticas e de representações simbólicas para se afirmar. No caso do Brasil, a independência monárquica, singular no contexto americano, conduziu à exacerbação do modelo português. Porém tratava-se, ainda, de fundar a legitimidade da nação em face das outra nações do mundo, ou seja, de ocupar um lugar dentre os países independentes. em síntese, não existindo a nação, o Estado promovia a sua criação, não só concentrando-a na figura do monarca, mas, também, representando-a simbolicamente por meio de cerimônias” (Maria de Barros Ribeiro. Os símbolos do poder, p. 72)

${ }^{46} \mathrm{O}$ espírito das roupas: a moda no século dezenove.
} 
quatro dias do ano.” (p. 40) ${ }^{47}$

O debate entre essas figuras também obedece a finalidades estritas: resolver contendas de ordem pessoal (papel da Madrinha de Leonardo-filho) ou oficializar pendengas no âmbito da justiça (Maria, tia de Luizinha). Além disso, assegura o ritmo agitado da narrativa, em meio às demais turbulências protagonizadas por Vidigal (ordem), Leonardo-filho (desordem), e o padre de meia-batina (síntese).

Também em $O$ Alienista, a ênfase não recai no ambiente doméstico, como se percebe na ficção dos outros escritores realistas (inclusive em algumas páginas do próprio Machado). O espaço público da vila de Itaguaí é implicitamente dado, apenas o suficiente para revelar as diferenças socioeconômicas de uns e outros e os interesses políticos que culminam na revolução. Ilustram-no as dimensões das moradias do médico Bacamarte e do albardeiro Mateus versus a presumível modesta barbearia de Porfírio.

Em Vida e morte de M. J. Gonzaga de Sá, os locais por que circula o sexagenário são aqueles que bem conhece e melhor questiona. Espaços amplos em contraste com os fechados. Reflexão generosa (o mar, a rua) em contraste com a conformação remunerada (a repartição pública) e a misantropia, (casa que divide com sua tia Escolástica).

Nas três obras as instituições sociais são configuradas para ser demolidas. Particularmente no romance de Almeida, o matrimônio (Maria das Hortaliças e Leonardo Pataca) é marcado pela força do adultério. Esse dado também pode ter contribuído para os críticos terem classificado Memórias de um Sargento de Milícias como romance pré-realista ${ }^{48}$. O escritor realista, de acordo com Massaud Moisés:

"Derrubadas as barreiras da conveniência ou das aparências, atira-se à realização dos sentidos, e com ela arrasta o casamento e, por tabela, o próprio sistema burguês. De onde, torpedear o casamento significava, para os realistas, trazer à luz as falhas das instituições que o sustentavam e nele se apoiavam: a Burguesia, como sistema de vida, a Monarquia, como sistema de governo, e a Igreja, como sistema ideológico. Romance de tese, por conseguinte, é o romance realista, tese segundo a qual a decomposição do corpo social se deve, em última análise, às instituições, que não acompanharam o progresso da Ciência e, com isso, deixaram de adaptar-se às novas situações criadas. (...) De onde os exageros, a escolha do patológico, com o fito de não deixar margem a se admitir que a sociedade, tal como se apresentava, pudesse ter esperanças de salvação.” (pp. 25-6) ${ }^{49}$

\footnotetext{
${ }^{47}$ Carnavais, malandros e heróis.

48 Segundo João Pacheco: "Manuel Antônio de Almeida apresenta uma obra com traços realistas, de tal modo patentes que parece mais lógico incluí-lo no período do Realismo do que na fase romântica” $(O$ Realismo, p. 18).

${ }^{49}$ História da literatura brasileira.
} 
No romantismo realista de Manuel Antônio de Almeida as personagens foram tratadas com certo escárnio e pouco comedimento, o que favoreceu ao autor pincelar figuras de maneira equilibrada entre a diversão e alguma seriedade: legítimo antecessor de Machado de Assis, como defende uma parcela da crítica brasileira. ${ }^{50}$

Na forma, foi uma voz que, no tom e de acordo com certos traços estilísticos, encontrou diálogo com a literatura do politicamente municiado Lima Barreto - realistamodernista, estrategicamente afastado do glamour da belle époque.

${ }^{50}$ Dizia Mário de Andrade: “Havia mesmo na maneira com que Manuel Antônio de Almeida se exprimia algo do estilo espiritual de Machado de Assis.” (Aspectos da literatura brasileira, p. 134) 
PARTE I - POTÊNCIA (Mando) 


\title{
Manuel Antônio de Almeida: recuo estratégico
}

\begin{abstract}
“Toda ciência consiste em se não largar as muletas enquanto não se tem bem segura a mitra na cabeça: o esquecimento desta regra é a desgraça de muita gente; largam-na antes do tempo, e caem então por terra os infelizes, perdendo o equilíbrio.” (Manuel Antônio de Almeida) $^{51}$
\end{abstract}

\section{Recepção}

Polígrafo por natureza e com a necessidade de sustentar os três irmãos desde muito jovem, Manuel Antônio de Almeida certamente ganharia maior mérito se sua obra fosse lida de uma forma mais coesa e organizada. ${ }^{52}$

Um dos caminhos abertos diz respeito à recepção orientada para o seu romance. Há um consenso por parte da crítica de que o escritor teria entrado para a posteridade exclusivamente em razão da publicação das Memórias. ${ }^{53}$ Opinião algo contestável, considerando-se a qualidade e pertinência de vários de seus artigos, principalmente aqueles assinados sob a condição de crítico literário.

Além de ter deixado algumas traduções, seus ensaios versavam não exclusivamente sobre literatura. Tais trabalhos poderiam ser somados às composições em verso e prosa, lembrando que Memórias de um Sargento de Milícias resultou em duas versões - a segunda, em romance, sujeita a muitos e severos cortes ${ }^{54}$.

O livro foi publicado no ano seguinte aos últimos registros da história em folhetim. ${ }^{55}$ As alterações a que a versão original foi submetida seguiram determinações do próprio escritor. A carreira do jornalista e romancista terminaria seis anos depois.

A morte de Maneco, em novembro de 1861, despertou em amigos e colegas de profissão uma espécie de zanga diante de seu trágico destino. Tal reação, que incluía a de seu antigo funcionário da Tipografia Nacional - Machado de Assis ${ }^{56}$ - era natural.

\footnotetext{
51 “As muletas de Sixto V”. Crônica publicada em 3 de setembro de 1854.

52 Retoma-se aqui a observação de Silviano Santiago a respeito do conjunto das obras machadianas.

53 A ponderação de Eugênio Gomes (Aspectos do romance brasileiro) talvez tenha colaborado na consolidação de tal posicionamento: "nenhum desses trabalhos esparsos revela de modo inconfundível o singularíssimo escritor que havia de passar à posteridade exclusivamente com um único romance” (p. 56).

${ }^{54}$ Vide a versão em folhetim, em reedição assinada por Reginaldo Pinto de Carvalho (2004).

55 “O que era um Folhetim? Há duas repostas possíveis: 1) texto ficcional (“romance-folhetim”) que se publicava em capítulos semanais ou diários num jornal, e cuja duração, indeterminada poderia ser de semanas ou anos; e 2) texto em tom de crônica, não necessariamente ficcional, que abordava assuntos diversos e não continuava necessariamente no número seguinte; era uma seção mais ou menos ‘independente’ em relação ao jornal.” (p. 28) - Mamede Mustafa Jarouche. In: Memórias de um Sargento de Milícias, 2003.

${ }^{56}$ [M. A. de Almeida] "Recebia quase que diárias queixas do chefe das oficinas sobre um rapaz aprendiz de tipógrafo, 'cujo trabalho não rendia', pois largava constantemente a ocupação para ir ler nos cantos pouco freqüentados da oficina. O rapazola foi um dia requisitado ao gabinete. Manuel Antônio de
} 
Estampava a frustração de uns e outros diante do desaparecimento de um escritor em relativo início de carreira, tido então não só como discreto romancista - como perpetuaram muitos manuais de literatura.

Do ponto de vista analítico, é curioso que a recepção das Memórias tenha dado margem a duas categorias de críticos: os defensores que, de praxe, vinculavam a estrutura da obra aos percalços de sua vida, como se pretendessem justificar certos lapsos do autor, por conta da fatura da obra. Havia também os críticos contrários, uns ainda mais severos que a média, que embasavam suas impressões de leitura em supostos ou reais equívocos de Manuel Antônio de Almeida, no manejo do vernáculo ou na estruturação do romance.

Afora os elogios ao homem, registrados nos jornais da corte nas semanas que se seguiram à morte do jovem escritor, e descontados os prefácios às duas primeiras edições póstumas do romance - deixadas por Quintino Bocaiúva (1863) e Francisco José Bethencourt da Silva (1876) - é notório o ostracismo a que foram submetidos seus precisos artigos de crítica literária.

As primeiras manifestações sobre o único romance de Manuel Antônio de Almeida chegaram muitos anos após a publicação de sua obra e se dividiam sem muita nitidez em dois grupos: uns que mais elogiavam do que depreciavam o livro, principalmente em razão da fidelidade com que o autor representara a sociedade carioca: "Quadro brilhante, painel imenso, em que há vida, graça e colorido nativo" (Franklin Távora, 1876); “um perfeito novelista, senhor dos assuntos que estudava, observador despreocupado, mas sagaz do meio em que vivia, sabendo conduzir com acerto e leveza as várias peripécias da intriga, desenhando com segurança os tipos arrancados à sociedade e ao ambiente circunstante” (Ronald de Carvalho, 1913); “[o autor] em cada passo do seu romance está nessa atitude cauta e prevenida, expressão, seja consciente ou inconsciente, de uma desconfiança interior, resignada e humorística, respeitante à fragilidade e contingência do mundo imaginário a que procura comunicar o sopro vital da arte. Valeu-lhe isso como um preservativo contra as pieguices da paixão, e manteve-o no campo do natural e do verdadeiro” (Xavier Marques, 1920).

\footnotetext{
Almeida simpatizou-se com ele e informou-se da sua vida. Soube que tinha um salário ínfimo, comia mal, morava mal, dormindo não raro nos bancos duros da oficina. Viu que se tratava de 'alguém' que precisava ser protegido e protegeu-o não só usando da rua posição de administrador, como honrando-o com sua amizade. Apresentou-o a Pedro Luiza Pereira de Souza, a Francisco Otaviano e a Quintino Bocaiúva. Foi o começo da carreira desse rapaz que se chamava Joaquim Maria Machado de Assis.” (Marques Rebêlo. Vida e obra de Manoel Antônio de Almeida, p. 95)
} 
Outros lhe fizeram mais críticas do que elogios: “Os principais méritos do livro são: naturalidade na exposição, viveza no diálogo e nas cenas descritas, graça, espírito no dizer, o nacionalismo do assunto e as cores do quadro (...) não saiu do Rio de Janeiro e limitou-se a descrever usos e costumes das suas classes plebéias dos começos do século XIX” (Silvio Romero, 1888). “O seu grande senão é a forma que não é nem artística nem bela, que não tem nem as rebuscadas elegâncias do estilo, nem essa espontaneidade que alguns espíritos de eleição sabem dar, por uma inspiração que é o dom do gênio, à forma de que revestem a sua criação” (José Veríssimo, 1900) ${ }^{57}$.

Felizmente, os estudos sobre as Memórias caminham em direção que desfavorece o dado meramente "otimista”, supostamente evidenciado na trama. A recepção da obra do escritor também está ligada à constituição do público leitor brasileiro. Hélio Seixas Guimarães lembra que:

“o censo de 1872 (...) apurou uma população de quase 10 milhões de habitantes, apenas 12 mil freqüentavam a educação secundária e havia 8 mil bacharéis no país. Esses dados indicam o leitorado potencial, o que significa que o número de pessoas efetivamente capazes de ler e escrever era certamente muito menor. Certamente muito menor era o número de leitores de literatura, o que fica indicado pelas tiragens. Os livros saíam em edições de mil exemplares, e apenas títulos muito bem-sucedidos chegavam à segunda edição, que podia demorar dez, vinte ou trinta anos. Nesse grupo incluíam-se as Memórias de um Sargento de milícias, com três edições esgotadas 'num período de vinte e poucos anos', segundo o redator da Imprensa Industrial.” (p. 66)

Embora seja apontado algo de leviano e aparentemente negligente, quando da confecção dos quase cinqüenta capítulos da obra, parece evidenciada a necessidade de se reavaliar determinados tópicos, sugeridos pelo próprio narrador - reforçados, aliás, quando se percebe a cautela com que determinados trechos foram amainados ao passar da condição de folhetim para livro.

Muito tempo foi necessário para que os ensaístas dessem conta mais especificamente de seu método de composição, incluído o terreno movediço em que circulariam as personagens. Tais figuras, aliás, mais que os costumes retratados, servem para trazer toda a força das Memórias à tona: parecem constituir o melhor atalho para se aprofundar o estudo do romance.

\footnotetext{
${ }^{57}$ Depoimentos extraídos de: Manuel Antônio de Almeida. Obra dispersa, pp. 155-68.

${ }^{58}$ Os leitores de Machado de Assis: o romance machadiano e o público de literatura no século 19. Recomenda-se a leitura do recente trabalho: Era no tempo do rei: a dimensão sombria da malandragem $e$ a atualidade das "Memórias de um Sargento de Milícias", de Edu Teruki Otsuka. São Paulo: FFLCH/USP, 2005. Tese de Doutorado. Orientação de José Antônio Pasta Junior.
} 
Talvez o artigo de Manuel Antônio Major, publicado em um periódico, em 1872, tenha sido o primeiro a destacar, ainda que brevemente, dados mais estritamente relacionados à constituição do romance de Manuel Antônio de Almeida:

"O Leonardo, cuja vida o autor escreveu desde o seu nascimento até a celebração do seu consórcio com Luisinha, é o tipo desses moços que, embora de bons instintos, ou porque lhes facultaram liberdade em demasia, ou porque faleceu-lhes educação, praticam erros $e$ entregam-se às paixões próprias de uma juventude sem guia nem consciência. O filho de Leonardo Pataca, por suas aventuras de rapaz, por seus desvairamentos de moço, interessa tanto que o leitor sente quando não o vê no primeiro plano do romance" (p. 345 [grifos meus]). ${ }^{59}$

A observação de Major interessa especificamente por encarar a trajetória do protagonista como fruto de uma espécie de predestinação. A tese, aliás, seria reelaborada um século depois por Antonio Candido - que fala em “sina”, como se verá adiante.

Ao lado da caracterização de Leonardo como "tipo”, Major revela um sintoma comum aos leitores desse romance: de certa forma, acabamos por nos identificar com Leonardo, o filho, solidariamente.

Além das personagens-tipo, haveria que se falar nos símbolos - estes, discretamente espalhados nas páginas do livro, como numa brincadeira de escondeesconde que contasse com os achados dos leitores mais avisados.

Como é sabido, somente em 1970 seria publicado um cuidadoso ensaio, balizado não somente em relevantes contribuições das décadas imediatamente anteriores, mas e principalmente nas implicações de forma e conteúdo, equilibrando num achado notável o que havia de pitoresco, mas também de sutil, no romance.

“Dialética da malandragem” pode ser considerado um marco da ensaística nacional. O trabalho de Antonio Candido resolve duas questões centrais para uma análise menos confusa da obra de Manuel Antônio de Almeida, a saber: que não se trata exatamente de um romance à moda picaresca (opinião anunciada por Walnice Galvão em 1962 e corroborada em 1979, por Roberto Schwarz); e que, além de ser uma bela crônica do Rio de Janeiro, com suas personagens-tipo mais ou menos equilibradas em manobras de poder e favor, pode ser resumido na notável fórmula traduzida em uma dialética, cujos termos são a ordem e a desordem - a primeira mais ou menos encarnada pelo major Vidigal; a segunda, empreendida, entre outros, por Leonardo-Pataca, Maria da Hortaliça e Leonardo, o filho - grupo a que escapam com relativo sucesso o padrinho e a comadre: malandros de segundo escalão porque relativamente melhor intencionados. É de A. Candido a opinião de que: 
"Leonardo pratica a astúcia pela astúcia (mesmo quando ela tem por finalidade safá-lo de uma enrascada), manifestando um amor pelo jogo-em-si que o afasta do pragmatismo dos pícaros, cuja malandragem visa quase sempre ao proveito ou a um problema concreto.” (p.23) ${ }^{60}$

Há uma manobra essencial, relacionada à forma do romance: o recuo temporal dos eventos narrados. Tal deslocamento histórico colabora no dado escapadiço do livro, mesmo porque ao fazê-lo, o narrador absorve a desculpa bem acabada de aproximar atitudes de personagens cômicas a verossímeis arbitrariedades de seres reais basicamente, o Major Vidigal e o Rei, majestade que, na versão em folhetim chega a participar de algumas cenas, como observou Reginaldo Pinto de Carvalho.

Almeida situa a história de Leonardo (o filho) no "tempo do Rei”, o que lhe permitiu pelo menos duas relevantes tarefas: 1) reconstituir um painel, ao mesmo tempo, divertido e patético dos costumes da corte e cortejadores; 2) revelar a contemporaneidade de alguns vícios na desordem instituída na capital do país, sem abrir mão do tom gracejador, inerente à concepção do romance.

O livro sugere o embate entre mandonismo (Vidigal) e anomia (Leonardo-filho); realça o gosto pela contenda (comum, como se vê, em praticamente todas as personagens do romance); expõe as relações estabelecidas sob a égide do favor; e desnuda literalmente a hipocrisia de padres e milicianos. Tudo se amarra para, num segundo momento, ser deslindado quase exclusivamente por lances de sorte, principalmente no que diz respeito a Leonardo.

Há um considerável número de ingredientes a sugerir uma outra dialética: a da identidade e seu contrário. Dialética que contagia certas figuras das Memórias e vem sintetizada na personagem ímpar que é Leonardo - filho de dois tamancudos lusitanos que teriam vindo a reboque dos escombros passadistas representados pela pomposa Corte.

A família real comandou uma verdadeira invasão dos espaços urbanos do Rio de Janeiro, completando, três séculos depois do "descobrimento" do Brasil - de forma arbitrária e violenta e em pleno século XIX, o século do racionalismo - a nova expropriação dos homens nascidos e os que já lutavam por se estabelecer aqui.

\footnotetext{
${ }^{59}$ In: Memórias de um Sargento de Milícias, 2003. (Publicado originalmente em: Revista Mensal da Sociedade Brasileira de Ensaios Literários, $4^{\circ}$ ano, n. 1, 30 de abril de 1872, pp. 683-688).

60 "Dialética da malandragem” In:

O discurso e a cidade. Recentemente, João Cezar de Castro Rocha defendeu a atualização da tese de Antonio Candido e da "dialética relacional", proposta por Roberto DaMatta, em 1978 (Carnavais, malandros e heróis) no ensaio "Dialética da marginalidade", publicado na Folha de São Paulo (Caderno Mais!) de 29/2/2004: "Já o modelo da dialética da marginalidade pressupõe uma nova forma de relacionamento entre as classes sociais. Não se trata de conciliar diferenças, mas de evidenciá-las, recusando-se a improvável promessa de meio-termo entre o pequeno círculo dos donos do poder e o crescente universo dos excluídos.” (p. 7)
} 
Na forma, o escritor apresenta recursos ora românticos, ora realistas. Procedimento que levou a crítica a classificá-lo através de termos que mais dizem sobre as estéticas que tentam margeá-lo do que sobre a fatura literária. Em função da demasiada preocupação com o aspecto híbrido do gênero ${ }^{61}$, romance folhetinesco que também é, esquecem-se algumas artimanhas. A sina de Leonardo ressente-se de um dado pseudo-histórico. Esboçava-se na trilha de seus pais.

"há (...) um hemisfério positivo da ordem e um hemisfério negativo da desordem, funcionando como dois ímãs que atraem Leonardo, depois de terem atraído seus pais. (...) Leonardo vai crescendo e participando ora de um, ora de outro, até ser finalmente absorvido pelo pólo convencionalmente positivo.” (p. 32)

As páginas dessa história, publicadas no Correio Mercantil, dividiam espaços com diversos anúncios de outra matéria e natureza - o que, se por um lado, permitiria destacar o apelo da obra para as demais chamadas do jornal, contrariamente, poderia levar o leitor a relativizar o papel do próprio capítulo seriado, encarando-o como texto diluído no leque aberto por tantos outros assuntos. Recentemente, Reginaldo Pinto de Carvalho anotou na reedição das Memórias, em sua versão em folhetim que:

"Havia entre folhetim e Pacotilha uma identificação que ia além do aspecto gráfico. Passava-se das demais matérias para o texto do romance e deste para aquelas, freqüentemente, sem nenhuma indicação gráfica, principalmente no final do folhetim. Além disso, irreverência e humor davam o tom a ambos.” (pp. 261-2) ${ }^{63}$

Marques Rebelo, gabaritado biógrafo de Manuel Antônio de Almeida, apontava em 1943 o descaso a que a leitura da obra fora submetida quando da época de sua publicação:

"tal publicação teve uma aceitação muito relativa. A tiragem foi pequena e não encontrou assinantes para esgotá-la. (...) As Memórias não se esgotaram, perderam-se no fundo da redação, comidas pelos ratos ou pelo mofo, não constituíram em livro um sucesso literário. Sucesso literário era o que conseguia José de Alencar publicando $O$ Guarani em folhetins, no 'Diário do Rio', ao tempo em que saía em livro a segunda parte das Memórias. Nenhuma revista literária falaria delas. Aquilo não era literatura, concordariam. Vinte anos depois Macedo ainda considerava as Memórias 'um estudo ameno e preciso de antigos costumes do país e de coisas nele passadas'.” (pp. 37-8) ${ }^{64}$

Se compararmos a narrativa de Almeida àquelas de Macedo e Alencar, logo

\footnotetext{
${ }^{61}$ Valem as considerações de Auerbach: "O princípio estético que está na base do Realismo moderno já tinha sido proclamado por Victor Hugo e seu grupo, por volta de 1830, um pouco antes da publicação dos primeiros romances realistas: é o princípio da mistura dos gêneros, que permite tratar de maneira séria e mesmo trágica a realidade cotidiana, em toda a extensão de seus problemas humanos, sociais, políticos, econômicos, psicológicos; princípio que a estética clássica condenava, separando claramente o estilo elevado e o conceito do trágico de todo contato com a realidade ordinária." (Introdução aos estudos literários, p. 242)

${ }^{62}$ Antonio Candido. Op. Cit.

63 “A autocensura nas Memórias de um Sargento de Milícias” In: Memórias de um Sargento de Milícias.

${ }^{64}$ Op. Cit.
} 
veremos a diferença de tom (da diversão à seriedade), o que - no primeiro caso - se explicita também nas ingerências do narrador. Em Memórias de um Sargento de Milícias o autor lança com aparente descaso, mas notável eficácia, um dos tiques adotados por Sterne ${ }^{65}$ e posteriormente traduzidos por Machado de Assis: o diálogo entre narrador e leitor.

O procedimento fazia relativizar não apenas a verossimilhança buscada pelos românticos, mas desnudar a artificiosa e exagerada distância entre ficção (a obra em si) e a recepção. A interferência do narrador, de certo modo, retira ou diminui a autoridade do leitor porque certas expectativas e conseqüentes re-interpretações são prognosticadas de antemão.

O jovem escritor chamava, assim, a atenção para a divertida e proveitosa articulação entre autor, narrador e leitor: a aproximação com Machado de Assis é inevitável, como já percebeu a crítica. É que em ambos os casos, fazer literatura de qualidade não objetivava apenas divertir os leitores - porventura acometidos pelo tédio ${ }^{66}$. Almeida e Machado deixaram numerosas pistas que nos levam para além do plano de suas obras: servem também a redirecionar nosso foco para algumas questões nacionais de cunho histórico.

O cotejo da versão das Memórias em folhetim com aquela no formato romance confirma tal procedimento. As sensíveis diferenças entre as versões revelam que o autor priorizou aspectos relacionados ao conteúdo e à linguagem. Além disso, foram abrandados alguns juízos de valor emitidos pelo narrador.

Mantiveram-se, no entanto, os constantes diálogos entre narrador e leitor ${ }^{67}$. Reginaldo Pinto de Carvalho, em seu estudo comparado sobre as duas versões da obra observou ainda que:

\footnotetext{
${ }^{65}$ Laurence Sterne parece ter sido referência para ambos os escritores. A título de ilustração, veja-se esta passagem de seu romance: "Faz tanto tempo que o leitor desta obra rapsódica se viu afastado da parteira, que é mais do que hora de mencioná-la novamente, tão-só para incutir na mente do dito leitor que ainda existe um corpo que tal no mundo, a quem, tanto quanto posso ajuizar do meu plano neste momento, --vou apresentá-lo de uma vez para sempre. Mas como pode ser abordada matéria nova, e muitos assuntos inesperados interporem-se entre o leitor e mim, assuntos que talvez exijam solução imediata, ---- seria conveniente cuidar que a pobre mulher não se perdesse, entrementes; --- visto que, quando ela se tornar necessária, de maneira alguma poderemos passar sem ela. Penso ter-vos contado que a boa mulher era pessoa de não pequena reputação e importância em nossa aldeia e em toda a região circunvizinha; --- que a sua fama se havia difundido até a orla e circunferência desse círculo de importância (...)” (Tristam Shandy, p. 71). A esse respeito, veja-se o ensaio "A forma shandiana: Laurence Sterne e Machado de Assis”, de Sergio Paulo Rouanet (Revista Teresa, 6/7, 2006).

${ }^{66}$ De acordo com Antonio Candido, as Memórias de um Sargento de Milícias "seguem uma tendência manifestada desde o decênio de 1830, quando começaram a florescer jornaizinhos cômicos e satíricos (...) [que] se ocupavam de análise política e moral por meio da sátira dos costumes e retratos de tipos característicos, dissolvendo a individualidade na categoria, como tende a fazer Manuel Antônio." (“Dialética da malandragem”, pp. 25-6).
} 
"A nova paragrafação adotada em livro atende a uma visão mais dinâmica e ágil da estrutura do texto. Nos folhetins os parágrafos são mais concentrados. Há que se considerar também as peculiaridades de cada veículo. (...) Manuel A. de Almeida procedeu também a uma considerável substituição lexical (...) O que predominou mesmo foram as substituições motivadas pela auto-censura do escritor, conseqüência das pressões do meio. (...) Os cortes foram ditados, em geral, por conveniência político-ideológica; a revisão, por concessões ao modelo retórico vigente. O caso mais eloqüente de auto-censura, quanto ao conteúdo, é o corte das referências ao rei. Em toda a obra, das vinte e tantas menções, treze foram riscadas; e referência direta, permaneceu apenas uma.” (pp. 266-7) ${ }^{68}$

\section{Recuo estratégico}

João Pacheco registrara que as intervenções desse narrador seguem paralelamente ao ideal divertido de elaborar o pseudo-testemunho de uma época, objetivo pretendido pelo autor:

"A narrativa se entrecorta de constantes vaivéns. O autor segue os passos de um personagem, a cuja companhia se entrega até as páginas tantas. De súbito, adverte o leitor (...) Passa então a apresentar-nos o outro personagem, abandonando aquele em cujo encalço viera seguindo. São numerosos os exemplos, de que me parecem desnecessárias novas citações. Anotemos o efeito irônico que o autor tira de tais recursos - a cujo emprego Machado de Assis não se esquivou. Manuel Antônio de Almeida não desconhece a onisciência de autor, a que se refere claramente (...) São comuns as suas intromissões ao longo de todo o entrecho. Aqui, para uma advertência ou uma observação. Ali, para um testemunho ou um esclarecimento. Pois o livro, em muitos pontos, tem um fundo documentário.” (p. 20) (99 $^{9}$

Texto mais ou menos encaixado nas estreitas definições dos manuais literários às vezes problematicamente acomodado sob o rótulo de romance pré-realista - é de se acreditar que as Memórias não estivessem exclusivamente aferradas ao projeto de registrar um painel de tipologia nacional.

Mencione-se a esse favor o fato de as personagens comporem uma sorte de quadro que traz os matizes que escapavam das duas ou três classes sociais, reconhecidas por aqui.

Além disso, considerando que a obra fosse em si mesma um apelo de leitura - o que também explica seu tom de "galhofa sem melancolia”, como diz Mamede Mustafa Jarouche - há que se considerar o papel do narrador: chamar a atenção do leitor recorrendo a cenas do tipo “pastelão”, abordando seres reais e outros, verossímeis, todos emaranhados em coisas sérias. Narrador e leitor dialogariam, de certo modo, por conta do estilo desbragado do romance. Lembra Berta Waldman que:

67 “O público do narrador é muitas vezes chamado de narratário. Quer os narratários sejam ou não explicitamente identificados, a narrativa implicitamente constrói um público através daquilo que sua narração aceita sem discussão e através daquilo que explica." (J. Culler. Teoria literária: uma introdução, p. 88). Adotou-se, neste trabalho, a forma narrador/leitor.

${ }^{68}$ Memórias de um Sargento de Milícias, 2004. 
"o autor adere ao tom coloquial, a um estilo de veio popular, que funciona sobretudo como carga de comicidade. É preciso lembrar que o elemento popular sempre foi cômico, sendo esse o ponto de aproximação de nosso autor com outro costumbrista da época, o comediógrafo Martins Pena. Ora, o cômico esvazia as pretensões heróicas e românticas pela eloqüência não heróica e nada romântica das ações humanas.” (p. 9) ${ }^{70}$

De uma forma ou de outra, o aparecimento das Memórias mexia com o senso comum, porque trazia um trato inovador em termos literários: lidar com o sério de forma jocosa, sem deixar de lado o retrato de paisagens e personagens, além de relembrar os vários costumes festivos praticados desde a época enquadrada pela narrativa. Segundo Eugênio Gomes:

"Nessa altura, o Romantismo, que já exercia o mais tirânico domínio sobre o meio literário brasileiro, tinha redobrado de intensidade com o recente aparecimento de José de Alencar, companheiro de Manuel Antônio de Almeida, na redação do "Correio Mercantil”, e fadado a tornar-se o mais popular e fecundo romancista de seu tempo. Assim, com a sua narrativa de presumível reação anti-romântica, o autor das "Memórias de um sargento de milícias” colocavase na situação afoita e temerária de quem quisesse nadar contra a maré... E, seja dito, maré montante, que ameaçava envolver tudo em suas rebentações”. (p. 55) ${ }^{71}$

A opinião do biógrafo Marques Rebelo é similar:

(...) tivemos um punhado de escritores que cultivaram como José de Alencar e Gonçalves Dias um indianismo de ópera, aliado a um sentimentalismo convencional e enfeitado (...) em ambiente de tamanha falta de originalidade, num meio dominado pelo espírito de Chateaubriand, Lamartine, Vitor Hugo, Longfellow, Byron e Cooper, é realmente para assombrar o aparecimento de Manuel Antônio de Almeida, corajosamente rompendo com as convenções literárias vigentes, trazendo pela primeira vez qualquer coisa de novo e original para a nossa literatura, fenômeno que infelizmente muito poucas vezes se repetiu.” (pp. 41-2) ${ }^{72}$

\section{Antonio Candido notara que seus}

“contemporâneos, embora estimassem em Manuel Antônio o homem e o jornalista, parecem não ter prezado igualmente o seu livro, meio em desacordo com os padrões e o tom do momento. De fato, o extremismo poético e o extremismo fantástico se digerem mais facilmente, numa época de exaltação sentimental e vocação retórica, do que a demonstração de cabeça fina em que ele timbrou, no seu livro de costumes urbanos. Não se havia de digerir, sobretudo, a surpreendente imparcialidade com que trata os personagens, rompendo a tensão romântica entre o Bem e o Mal por meio de nivelamento divertido dos atos e caracteres (...) deixa ver ao leitor que, no fundo, uns valem os outros: nem bons, nem maus.” (p. 195)

Afrânio Coutinho segue em mesma direção:

\footnotetext{
69 “Uma voz se antecipa” In: O realismo.

${ }^{70}$ Memórias de um Sargento de Milícias, p. 9.

${ }^{71}$ Aspectos do romance brasileiro.

${ }^{72}$ Vida e obra de Manoel Antônio de Almeida.

73 "Manuel Antônio de Almeida: o romance em moto contínuo" In: brasileira: momentos decisivos. Vol. 2. Formação da literatura
} 
"não estava o livro em acordo com a atmosfera romântica do tempo em que se publicou, o que dava lugar a certa incompreensão por parte dos leitores, acostumados aos dramas românticos ou aos personagens encharcados de lirismo e às deformações da realidade” (p. 16) ${ }^{74}$

João Pacheco chamou a atenção para o entre lugar do romance:

[A obra] "passava ela por uma manifestação antecipada do Realismo, de que seria precursora, se bem que, entre ela e a escola realista, não se encontrasse elo bastante preciso a ligá-las; do que não se duvidava é estar ela fora do Romantismo, de cujo espírito aberrava.” (p. 16) ${ }^{75}$

Cada um dos quarenta e oito capítulos contém na forma um apelo de leitura; no conteúdo, uma ou duas anedotas. E o aspecto movediço do enredo, devidamente protagonizado por personagens flutuantes, justifica - quando não favorece - o encadeamento de episódios, no romance. A tese é de Antonio Candido:

“O movimento de sarabanda é, aliás, tão vivo, constitui de tal forma o nervo da composição, que as pessoas, nele, valem na medida em que se agitam; fora de cena, desaparecem (...) Os figurantes interessam, pois, na medida em que contribuem para o acontecimento, não como unidades autônomas. É o contrário do que sucede em Machado de Assis - onde os acontecimentos só importam na medida em que contribuem para acentuar a singularidade do personagem. O método literário de Manuel Antônio implica uma subordinação deste, - que o autor vira daqui, vira dali, revira adiante, torna a virar, pela razão de que cada virada, cada nova posição acarreta nova situação da narrativa em geral. O personagem necessita, pois, mudar de posição a cada passo, a fim de que o movimento não cesse.” (p. 198) ${ }^{76}$

Transparece uma especial atenção do autor para com os espaços, que reforçam a correria das figuras. ${ }^{77}$ A aparente fugacidade da estrutura anedótica despista o leitor ou coloca-o à frente de um labirinto temático em constante atualização na própria narrativa: costumes manifestados nos retratos das figuras; dados históricos ilustrados pelas profissões e costumes da época; história e ficção enovelados por força da tradição, do amor, da autoridade e das crendices. Continuando com Antonio Candido:

"A força de convicção do livro depende pois essencialmente de certos pressupostos de fatura, que ordenam a camada superficial dos dados. Estes precisam ser encarados como elementos de composição, não como informes proporcionados pelo autor, pois neste caso estaríamos reduzindo o romance a uma série de quadros descritivos dos costumes do tempo. (...) Manuel Antônio, apesar de sua singeleza, tem uma coisa em comum com os grandes realistas: a capacidade de intuir, além dos fragmentos descritos, certos princípios constitutivos da sociedade - , elemento oculto que age como totalizador dos aspectos parciais.” (pp. 29-30) ${ }^{78}$

\footnotetext{
74 “Introdução” In: Almeida, Manuel Antônio de. Memórias de um Sargento de Milícias.

${ }^{75}$ Op. Cit.

76 “Dialética da malandragem”.

77 De acordo com Wolfang Kayser: "O romance de espaço recebe no século XIX especial colorido e, simultaneamente, uma limitação. Como finalidade surge agora a representação deste mundo atual, contemporâneo, - muitas vezes só de um setor nitidamente delimitado. O que correntemente se designa por romance de época e romance de sociedade são apenas tipos especiais do romance de espaço” (Análise e interpretação da obra literária, p. 269)

78 “Dialética da malandragem”.
} 
Mas por que, afinal, Manuel Antônio de Almeida, tendo começado a publicar a história em folhetins, no início da década de 50, aos vinte e um anos de idade, recuou cronologicamente os acontecimentos para o “tempo do Rei”? Uma explicação parcial foi apontada por Eugênio Gomes:

"As histórias do tempo do rei que o romancista recolheu, quando ainda subsistiam na cidade do Rio de Janeiro tantos de seus usos e costumes, levaram-no, por uma feliz intuição, a escolher um gênero de narrativa que, por sua técnica maleável e despachada, era o único que abria melhor possibilidade à pintura daquele tempo.” (pp. 64-5) ${ }^{79}$

Há que se considerar uma antiga tese de Nelson Werneck Sodré, retomada por Reginaldo Pinto de Carvalho, em 1999, e atualizada mais recentemente, por ocasião da reedição do folhetim:

"O recuo da história ao tempo do rei, portanto um recuo de aproximadamente quarenta anos, já que o tempo do rei compreenderia o período que vai de 1808 a 1821, revela a intenção do autor de evitar a crítica direta a seu próprio tempo. A própria determinação prévia de situar os fatos narrados no passado, mesmo que próximo, já denotava cautela. Para Sodré, esse recuo é um disfarce. Diz ele: 'A antecipação histórica, aliás, poderia ter sido uma saída natural e intencional do autor, para fazer crítica - e há muita crítica transparente nas páginas do livro - e não chocar os criticados'." (pp. 279-80). ${ }^{80}$

\section{Outra, de Mamede Mustafa Jarouche:}

"Malgrado as Memórias de um Sargento de Milícias não apresentarem uma única frase diretamente partidária, muito de seu conteúdo - as críticas aos sistemas judiciário e educacional, à polícia, ao clero, aos imigrantes portugueses, ao sistema de proteção e empenho, além do próprio comportamento 'solto' demais das personagens (a grande maioria não tem educação) pode ter sido lido como alegoria da situação presente no Brasil. (...) O que o autor pretendeu dizer? Talvez, de forma irônica, ele estivesse insinuando que o Brasil de seu tempo não seria lá muito diferente do Brasil no tempo de Dom João VI. Nesse sentido, as Memórias poderiam constituir uma espécie de sátira social” (p. 33) ${ }^{81}$

Como o romance é escrito em franco tom de mofa, a tendência é que os dados com aspecto de verdade entrem em sua grande brincadeira. Não são os tipos fictícios acometidos de algo "de verdade”; e as celebridades que de fato teriam existido são

\footnotetext{
${ }^{79}$ Aspectos do romance brasileiro. A ele se opôs Temístocles Linhares: “(...) tão viva e palpitante nele se mostra a influência da crônica que seria absurdo crer apenas na intuição poderosa de seu espírito de observação" (Histórica crítica do romance brasileiro, p. 117)

${ }^{80}$ Edição de 2004 (versão em folhetim). O próprio Reginaldo Pinto de Carvalho observa que "Além da própria biografia do autor justificar tais cuidados na revisão das Memórias (referimo-nos a sua origem humilde, à necessidade de ascensão social, à busca de proteção etc), os depoimentos (todos escritos após o desaparecimento do escritor e de pouca ou nenhuma repercussão) dos contemporâneos também apontam para um Manuel A. de Almeida injustiçado ou mesmo perseguido.” (p. 278).

81 "Galhofa sem melancolia” (ed. do romance de 2003). Mamede Jarouche lembra ainda que "em 18521853, a produção 'oficial' da história do Brasil era monopolizada pelo Instituto Histórico e Geográfico Brasileiro, fundado em 1838 sob os auspícios de Dom Pedro II. Conforme as publicações do IHGB, a época do rei tinha sido a maravilha das maravilhas, introduzindo no Brasil amplas melhorias com suas ‘sábias medidas'. Ai daquele que saísse da linha: seria pulverizado, chamado de ignorante, mal-
} 
sugadas pelo redemoinho juntamente com as figuras criadas pelo autor. Ambas as categorias tornam-se definitivamente caricatas, de forma que uns e outros participam de uma nova coletividade - esta, indistinta, fabricada com um toque de realismo e outro de piada.

Para que a narrativa leve ao riso, o autor retira o peso do gênero histórico, como se confirmasse a tese de que a história não está tão distante da ficção, ou vice-versa. Por outro lado, sugere o preenchimento, pois feito de forma verossímil, de algumas supostas lacunas, ignoradas pela historiografia.

Estando o autor abrigado pela distância temporal e a ficcionalidade do registro dos eventos, teoricamente transcorridos no "tempo do rei” (ou seja, na segunda invasão do Brasil pelos portugueses), ainda assim o livro põe em xeque a imparcialidade objetivada pela história oficial - ciosa por ocultar os detalhes da vida doméstica, tão de agrado do narrador da crônica romanceada.

Dois motivos justificariam o apego do narrador aos assuntos eminentemente domésticos: o primeiro diz respeito à própria comicidade, despertada pelo contato mais próximo do leitor com os costumes e certas intimidades de determinadas personagens. O segundo pode estar na intenção do autor de desmistificar os assuntos levados em pouca conta pela história oficial. Daí ser duplamente engraçado o papel do narrador que discursa com modos de imparcial, mas, ao mesmo tempo, leva o leitor ao julgamento das figuras, sempre em benefício do próximo episódio.

Em suma, Manuel Antônio de Almeida bem sabia que uma das características da matéria histórica é a repetição. O foco do escritor é a sua contemporaneidade, o que implica dizer que falar do de ontem permitiria deduzir o de hoje - ainda que de maneira abrandada pelo riso que despertasse. $\mathrm{O}$ autor tinha em mira a continuidade aprimorada de determinadas arbitrariedades: causas e/ou resultados das intermináveis contendas.

Os confrontos são ilustrados pelas rixas entre vizinhos, mas também na disputa maior pela moça prendada. Luzinha está colocada justamente a meio caminho entre o malandro por acaso, Leonardo, e o malandro por ofício, José Manoel - casamenteiro interessado no dote de moças bem-nascidas.

A existência de uma personagem situada à meia distância entre dois "tipos" irresponsáveis revela as nuanças entre os malandros da Corte. Não parece por acaso que o nome do pretendente rival $^{82}$ de Leonardo remeta a outro território: trata-se de

intencionado e outras amabilidades. Pois bem: quem ler as Memórias de um Sargento de Milícias com atenção notará que a sociedade ali representada não é nenhuma maravilha.” (p. 39) 
concorrente desleal, com nome de origem eminentemente portuguesa. Portugal versus Brasil.

\section{Um brasileiro}

Filho do acaso, Leonardo-filho, como se naturalmente contaminado pelo desinteresse de ambos os pais, sugestivamente terá seu nome (sem sobrenome $=$ sem responsabilidade?) revelado praticamente na metade do livro, dado que não pode ser ignorado, uma vez que esse herói do avesso também personifica um instintivo desapego às instituições sociais, religiosa e militar. Portanto, não são poucos os pilares desequilibrados, dentre aqueles tratados no romance. Nas palavras de Walnice Nogueira Galvão:

"Embora Leonardo seja fortemente caracterizado, o autor não nos esclarece mais profundamente a seu respeito. Leonardo arrasta a nossa adesão por sua verve, seu desapego às convenções, seu espírito aberto a todas as aventuras." (p. 31) ${ }^{83}$

O leitor não deve se eximir de procurar na trajetória de Leonardo-filho algumas curiosas implicações estreitamente ligadas a sua origem. Os dois ou três primeiros capítulos do romance, em particular, fornecem praticamente todas as pistas para a presente interpretação.

Servem inclusive de contraponto aos capítulos restantes, que estão lá mais para ilustrar certo fatalismo histrião que contagia a carreira e as correrias do herói e antiherói. $^{84}$

\footnotetext{
82 "Figure o leitor um homenzinho nascido em dias de maio, de pouco mais ou menos trinta e cinco anos de idade, magro, narigudo, de olhar vivo e penetrante, vestido de calção e meias pretas, sapatos de fivela, capote e chapéu armado, e terá idéia do físico do Sr. José Manuel, o recém-chegado. Quanto ao moral, se os sinais físicos não falham, quem olhasse para a cara do Sr. José Manuel assinalava-lhe logo um lugar distinto na família dos velhacos de quilate. (...) Se tinha alguma virtude, era a de não enganar pela cara.” (Memórias de um Sargento de Milícias, pp. 186-7). Com Walnice Galvão: "Manuel Antônio de Almeida é intransigente na fidelidade ao estilo baixo. Recusa-se a uma visão romanesca ou embelezadora do real, encara resolutamente o ridículo do homem e de suas obras. Homens e mulheres são gordos demais ou demasiado magros, muito altos ou muito baixos, os trajes são cômicos, os rostos grotescos, os hábitos e costumes risíveis." ("No tempo do rei”, p. 30). Efeito similar ao que W. Kayser notou em A cidade e as serras, de Eça de Queirós, em Milícias: "Há uma situação vaga e solene que é interrompida pela realidade crua e iminente” (Op. Cit., p. 198, Vol. 2).

${ }^{83}$ Op. Cit.

${ }^{84}$ Fato pouco aprofundado pela crítica é a menção “Um Brasileiro”, em lugar do nome do autor, quando da publicação das Memórias em folhetim. A assinatura, de acordo com a opinião corrente, seria um pseudônimo de Manuel Antônio de Almeida. Entretanto, não seria produtivo considerar "Um brasileiro" a um só tempo como seu pseudônimo e subtítulo do próprio romance, numa tentativa de pré-definir a trajetória de Leonardo-filho? O argumento corroboraria a idéia de que a criança gerada em alto-mar fosse, mesmo, uma personificação de nosso país, nação ansiosa por sugar a essência portuguesa (alimento espiritual), para nutrir-se enquanto enfraquecesse a condição da corte: “(...) formidável menino de quase três palmos de comprido, gordo e vermelho, cabeludo, esperneador e chorão; o qual, logo depois que nasceu, mamou duas horas seguidas sem largar o peito. E este nascimento é certamente de tudo o que temos dito o que mais nos interessa, porque o menino de quem falamos é o herói desta história.” (p. 68)
} 
Mas, numa dinâmica peculiar, também faz as vezes de anti-herói que se torna herói, subindo na hierarquia social para assumir o posto de sentinela público e perpetuar à sua maneira o “jeitinho" do próprio Vidigal. O alerta é sério e pode ser contextualizado. Segundo Raymundo Faoro:

"A patente das milícias correspondia a um título de nobreza, que irradiava poder e prestígio, cifrando-se nas promoções e graus de oficiais as prometidas mercês do rei aos paulistas que abrissem as minas escondidas nos sertões. A patente embranquece e nobilita: ela está no lugar da carta de bacharel, no Império. (...) A organização militar constitui a espinha dorsal da colônia, elemento de ordem e disciplina, auxiliar na garantia da cobrança dos tributos e dos privilégios reais. O caráter, a postura vertical, os padrões europeus de ética foram infundidos pelo padre, sobretudo pelo jesuíta. O missionário encontrou duas tarefas diante de si: a conquista espiritual do indígena e o domínio do branco, contendo o deslumbramento do português diante da presa sexual e da presa apta ao trabalho não pago.” (pp. 222 e 228) ${ }^{85}$

Leonardo, o filho, é patentemente rejeitado por seus pais. Sua inopinada vinda ao mundo ilustra as circunstâncias de uma gestação por acidente. Fruto da "pisadela e do beliscão” - do amor de passagem - o filho reproduz a história que não se efetiva, o aborto em vida, a vivência à deriva, como se reafirmasse em terra as oscilações do barco que liga a colônia ao Império.

Ora, o Oceano que une Portugal ao Brasil é uma ponte tênue que empresta a Leonardo-Pataca $^{86}$ e Maria das Hortaliças a volubilidade (talvez derive daí o sentimentalismo de um e a infidelidade da outra). Volubilidade, aliás, que norteia pelo avesso o fado do filho, vivendo rigorosamente na instabilidade frente às regras.

Por isso, parece difícil seguir a convenção, respeitar os costumes, a religião dominante, manter o emprego fixo, ou obedecer a questionável autoridade policial. Leonardo filho revoluciona sem disciplina, o que anula ambos os $\operatorname{conceitos}^{87}$. O seu

\footnotetext{
${ }^{85}$ Os donos do poder. De acordo com Gilberto Freyre: “o indivíduo, durante sua existência romanesca (...) pode ser, com relação ao seu meio e ao seu tempo sociais, normal ou anormal, com essa normalidade ou anormalidade sugerida por símbolos que o identifiquem como 'imoral' ou 'anti-social'." (Heróis e vilões no romance brasileiro, p. 11). Segundo Massaud Moisés, o aparecimento do anti-herói "resultou da progressiva desmitificação do herói, ou seja, de sua crescente humanização: com o despontar do romance, no século XVIII, os representantes de todas as classes sociais entraram a substituir os seres de eleição, semidivinos, que antes povoavam as tragédias e epopéias.” (Dicionário de termos literários, p. 29).

${ }^{86}$ Segundo Mário de Andrade, havia um “sargento veterano que contava ao Maneco Almeida casos do tempo do rei velho. Melo Morais Filho conheceu este sargento quando já desengajado, era diretor de escritório no Diário do Rio, após ter exercido estas mesmas funções no Correio Mercantil. Português de nascimento, chamava-se Antônio Cesar Ramos e viera como soldado para a guerra Cisplatina, em 1817, no Regimento de Bragança. Depois chegara a sargento de milícias, ainda na Colônia, sob o mando do major Vidigal.” (Op. Cit., pp. 128-9).

87 “o menino tem para a reza, e em geral para tudo quanto diz respeito à religião, uma aversão decidida” (Memórias de um Sargento de Milícias, p. 125). A postura de Leonardo-filho permite um questionamento do papel das instituições sociais estanques, incluída aí a religião, que, para Terry Eagleton é "por todas as razões, uma forma extremamente eficiente de controle ideológico. Como todas as ideologias de sucesso, ela age muito menos pelos conceitos explícitos, ou pelas doutrinas formuladas, do que pela imagem, símbolo, hábito, ritual e mitologia (...) pelo menos em suas formas vitorianas, é uma influência
} 
desapego pelo trabalho é notório. A grande ironia é que o jovem receberia um posto miliciano justamente no momento em que se preparava o seu casório com a bem nascida Luzinha. Para Roberto Schwarz, em adendo ao ensaio de Antonio Candido:

"Trata-se, noutras palavras, da formalização estética de um ritmo geral da sociedade brasileira da primeira metade do século XIX. Paradoxalmente, a apreensão deste ritmo está ligada às limitações do romance enquanto documento. Com efeito, ao suprimir o escravo, o romancista suprimia quase totalmente o trabalhador; e suprimindo as classes dirigentes, suprimia os controles do mando. Ficava-lhe um setor intermédio e anômico da sociedade, cujas características serão decisivas para a ideologia dela. Um setor em que a ordem só dificilmente se impunha e mantinha” (p. 132)

Os procedimentos de Leonardo filho revelariam um sintoma dos filhos mal nascidos e, permanecendo aqui, malcriados. Parece plausível interpretar a nomeação do jovem traquinas como sargento, bem como seu casamento com a amada moça prendada, como a vitória da malandragem sobre a compostura. Significa que uma se equipararia à outra, e permitira ler de forma invertida as “súcias” em que se mete o herói: sintomas do desajuste do seio de onde vem.

O final feliz, apesar de combinar com o tom geral do romance, aceita outra interpretação, menos otimista e festiva da trajetória de Leonardo, filho. Prosseguindo com Berta Waldman:

“o 'destino’ o reaproxima de Luisinha, já viúva, e ele retoma o namoro que o levará direto ao casamento, para viverem a felicidade cinzenta e neutra que a pena de Manuel Antônio de Almeida se recusa a descrever, finalizando-se nesse ponto o romance.” (pp. 10-11) ${ }^{89}$

Aliás, qual a garantia de que o emprego associado à autoridade policial e a ligação a uma mulher - obedecido o estrito sacramento religioso - dessem conta da natureza sabidamente instável de Leonardo?

A volubilidade contagia não somente os pais do menino chorão, mas também a segunda paixão de Pataca: a Cigana que tem um caso com o Padre, este o primeiro empregador de Leonardo-filho.

Se de um lado, o padre, que personifica a religião oficial, recrimina o paganismo, por outro, divide a cama com uma mulher não-batizada e revela as brechas dissimuladas pela retórica sacramentada - é claro, com as folgas permitidas pelas tradições que para cá vieram transplantadas sem raiz.

pacificadora, que estimula a humildade, o auto-sacrifício e a vida interior contemplativa.” (Teoria da literatura: uma introdução, pp. 30-1).

${ }^{88}$ Que horas são?

${ }^{89}$ Op. Cit. Mário de Andrade referiu-se à "burguesia cinzenta” de Leonardo-filho, quando passa ao posto de Sargento: “O livro acaba quando o inútil da felicidade principia” (Op. Cit., p. 135) 
A postura do padre relembra uma das chaves para compreender a movediça trajetória de outro malandro. Para Mário de Andrade: "Filho de uma pisadela e um beliscão de reinóis imigrantes, Leonardo nasce ilegítimo para viver vida ilegítima até o fim do romance.” (p. 129)

Não é desprezível o fato de os pais (Pataca e Hortaliça) serem dois empregados modestos, algibebe e quitandeira: representam a emigração de grandes remessas de pequenos burgueses lusitanos para a colônia - pedaço de terra com que não nutriam vínculo ou afeição.

Leonardo é fruto, portanto, de um encontro furtivo efetivado enquanto o navio promovia a ligação dos pais à sua terra de nascimento. Em solo semi-brasileiro, seria gradativamente rejeitado, primeiro pela mãe - pouco afeita à fidelidade, à vida conjugal e seu apaixonado marido -; depois, pelo pai, Leonardo meirinho, Leonardo-Pataca, Leonardo de valor nenhum.

"Os meirinhos desse belo tempo (...) não se confundiam com ninguém; eram originais, em tipos: nos seus semblantes transluzia um certo ar de majestade forense, seus olhares calculados e sagazes significavam chicana. Trajavam sisuda casaca preta, calção e meias da mesma cor, sapato afivelado, ao lado esquerdo aristocrático espadim, e na ilharga direita penduravam um círculo branco, cuja significação ignoramos, e coroavam tudo isto por um grave chapéu armado. Colocado sob a importância vantajosa destas condições, o meirinho usava e abusava de sua posição.” (p. 66)

Enquanto a mãe, Maria da Hortaliça, retoma os caminhos que motivaram a sua vinda para o Brasil, - uma quitandeira na terra das oportunidades - o pai-Pataca troca a antiga função de algibebe de Portugal ironicamente pela de meirinho do Rei num território, por extensão, ainda lusitano.

"Entre os termos que formavam essa equação meirinhal pregada na esquina havia uma quantidade constante, era o Leonardo-Pataca (...) Sua história tem pouca coisa de notável. Fôra Leonardo algibebe em Lisboa, sua pátria; aborrecera-se porém do negócio, e viera ao Brasil. Aqui chegando, não se sabe por proteção de quem, alcançou o emprego de que o vemos empossado, e que exercia, como dissemos, desde tempo remotos. Mas viera com ele no mesmo navio, não sei fazer o que, uma certa Maria da Hortaliça, quitandeira das praças de Lisboa, saloia rochonchuda e bonitona. Quando saltaram em terra começou a Maria a sentir certos enojos: foram os dois morar juntos: e daí a um mês manifestaram-se claramente os efeitos da pisada e do beliscão” (pp. 67-8)

De certa forma, cada um dos sintomas percebidos na sociedade provinciana vem rigidamente marcado, nomeado por figuras pictóricas, tão evidentemente engraçadas que fazem desconfiar do tom de puro divertissement da obra.

\footnotetext{
${ }^{90}$ Op. Cit.

${ }^{91}$ Citações de: Memórias de um Sargento de Milícias. São Paulo: Cotia, 2003. De acordo com Nelson Omegna "o estrato das profissões militares [era] bastante largo, sendo certo que alguns postos e patentes outorgam situação de prestígio social, ainda que economicamente os indivíduos necessitem de outras profissões para o sustento.” (A cidade colonial, p. 124)
} 
Assim, Maria (contenda), Hortaliça (infidelidade), Regalada (favorecimento sexual), Vidigal (mando e desmando), Leonardo-Pataca (volubilidade), o Padrinho (herança imprópria), a Comadre (astúcia) e Leonardo-filho (malandragem) constituem um painel de personagens que, tipificadas sob a pena aparentemente leve do autor, respondem em conjunto por um levantamento aproximado de certas características comportamentais do brasileiro - ao modo de Leonardo-filho, sem sobrenome, sem pais, sem identidade única.

O romance alia à descrição de tipos sociais, politicagens do favor que fazem dançar todas as personagens no intervalo entre a compostura e a malícia. Tomando a observação de Mário de Andrade:

"Mesmo na descrição mais exata e séria que faz dos costumes, chega a ser um bocado angustiosa a maneira com que ele se priva de admiração, cuidando sempre de retirar a beleza possível das imagens que pinta. (...) Por vezes se eleva sobre o caricato, mas é pra empunhar o estilete mais sutil do humorismo.” (p. 138) ${ }^{92}$

Ora, Leonardo é filho de um instante de grosseria ("beliscão”), comum ao casal de tamancudos portugueses; da falta de compromisso (daí o casamento sem regras de seus pais) e seu destino parece ondear como o navio em que foi gerado, na falta de rumo. O desgoverno, aliás, combina-se à linguagem absolutamente direta de seu autor. Para Afrânio Coutinho:

"Uma tônica do romance é a sua linguagem. Pela primeira vez na ficção brasileira, a língua falada é utilizada por um escritor sem a menor reserva e com toda a dignidade e naturalidade. A isso deve-se o caráter espontâneo da narrativa, que corre despretensiosa, tal como é falada pelo personagem, sem os artifícios a que a submetem ainda os escritores do tempo.” (p. 17) ${ }^{93}$

Darcy Damasceno já havia pinçado a inovação formal aportada pelo romance como recurso a ser considerado na própria constituição das numerosas tramas e figuras escorregadias:

“A exemplo do que no teatro fizera Martins Pena, Almeida renovou no romance a expressão formal, embora, como é óbvio, também aqui passasse despercebida a importância do fato. (...) núcleo social que se impõe, unido e interdependente, fazendo-se personagem coletiva e primeira. Outras figuras que aí aparecem, se fogem à condição social daquelas, ou são de modesto valor (...) ou surgem na trama para atestar a ligação entre distintos níveis sociais, como D. Maria, velha abastada e litigante, que tanto freqüentavam o barbeiro e a parteira como o almofadinha José Manuel. A tais figuras dispensa o autor tratamento diferente, laivado de ironia, ao contrário da afeição - disfarçada, mas comprovável - regalada aos principais tipos do grupo-personagem. Se tais figuras, pela razão mesma de sua elevação à categoria de personagens, deviam comportar-se lingüisticamente como na realidade, ao narrador, não menos, impunha-se o manejo de um instrumento idiomático bem diverso do utilizado na expressão literária de seu tempo, ou seja a "linguagem chã" levantada contra os "trejeitos da retórica".

\footnotetext{
${ }^{92}$ Aspectos da literatura brasileira.

93 “Introdução” In: Memórias de um Sargento de Milícias.
} 
Graças a essa linguagem, poderíamos dizer que o maior mérito das Memórias é ser um livro onde o descuramento formal se fez traço estilístico.” (p. 159) ${ }^{94}$

Parece plausível atribuir ao então jovem e talentoso escritor a intenção de estabelecer uma divertida composição, arquitetada a partir de alguns elementos combinados, cujos rastros, como já dito, transparecerem nos capítulos iniciais: a) na composição das personagens, a tipificação social, a fixar desde cedo os caminhos por que trilharia o desencaminhado Lenardo-filho bem como o rei, o major, os meirinhos, a quitandeira, a parteira e o barbeiro; e b) na forma, o enredo em ritmo folhetinesco. Não custa lembrar que, historicamente:

“o rebelado, o valentão, o boêmio, o feitor maldoso, o Don Juan pachola, o chefe mesquinho, o cangaceiro perigoso nascem quase sempre da mesma matriz da marginalidade que começou a se elaborar nos quadros de uma sociedade cuja estrutura, fundada na estratificação econômica, embaraçava a promoção de quem não queria ser mão-de-obra barata e não podia ser proprietário poderoso.” (p. 186)

Não há dúvida quanto ao relevante papel dos pais postiços do malandro Leonardo-filho, não por acaso padrinhos de batismo - sacramento que inaugura suas diabruras:

"Chegou o dia de batizar-se o rapaz; foi madrinha a parteira; sobre o padrinho houve suas dúvidas: o Leonardo queria que fosse o Sr. Juiz; porém teve de ceder a instâncias da Maria e da comadre, que queriam que fosse o barbeiro de defronte, que afinal foi adotado.” (p. 68)

Ora, o “chorão” Leonardo nasceu quase por acaso, tendo sido encomendado não em solo firme, mas oscilante, já que em alto-mar. O oceano que une para instantaneamente desunir dois portugueses é o mesmo que estabelece a já tênue ligação entre a metrópole e a colônia. É pelo mar ainda que os aventureiros vêm ao Brasil; e, no caso, não parece coincidência desprezível o fato de Leonardo (herdeiro do nome e dos trejeitos do pai) ter sido rejeitado pelos progenitores.

Aqui, alguma alegoria: Leonardo-filho é um estorvo para os pais, assim como a colônia Brasil tornava-se um fruto pesado para a matriz Portugal. O pai, LeonardoPataca, encarna a numerosa parcela de lusitanos que para cá vieram a assumir os postos medianos distribuídos pelo reino: um dos fatores que marcou, como é sabido, o antilusitanismo dos brasileiros, igualmente ávidos por ocupar sua boquinha na generosa e dispendiosa administração, cujos numerosos componentes cercavam por intermédio de

\footnotetext{
94 “Afetividade lingüística nas Memórias de um Sargento de Milícias”. Revista brasileira de filologia. V. 2, tomo II.

${ }^{95}$ Nelson Omegna. Op. Cit.
} 
uma aparente rígida obediência à longa fila hierárquica, o umbigo do rei e sua corte. Jamil Haddad havia intuído a idéia há algumas décadas:

"Pai lusitano não deu nunca ao Brasil filho lusófilo; pelo contrário, deu-o lusófobo, como entre numerosos casos, o de nosso romancista pode evidenciar. A par da aludida lusofobia, aparece nele outra idiossincrasia peculiar também ao século décimo-nono brasileiro: o horror ao clero. Em parte, diga-se de passagem, justificada, pois que os sacerdotes longe estavam de constituir modelos de peregrina virtude. O Leonardo destinado à carreira eclesiástica é bem uma sátira inclusive aos processo de recrutamento dos padres (quando não das freiras) e que se processava longe por completo de qualquer sugestão mística.” (p. 10)

Talvez à “dialética da ordem e da desordem”, meio-termo flutuante a que ninguém quer ou pode escapar - nem mesmo o ordeiro Vidigal e os padres pudéssemos acrescentar uma outra. A trajetória de Leonardo-filho reside na dinâmica entre $a$ identidade e seu contrário: movimento intermitente a retratar não só a constante oscilação do herói, mas a aproximá-lo de um território, este, que estava politicamente no estágio intermediário entre a colonização e a independência e que, territorialmente, constituía um longo e bom pedaço de terra, servindo, à época, como mera extensão do decadente Império português.

Leonardinho não obedece ao papel duplo que se espera dos homens: individualidade + parte da unidade social ${ }^{97}$. A falta de identificação dessa personagem com qualquer instituição de ordem reguladora parece impregnar a própria fatura, numa poética “oscilante”. Berta Waldman reparou no ritmo da narrativa que:

"na segunda metade, a feição do livro altera-se, pendendo mais para o romance, porque a linha do filho passa a prevalecer na narrativa, diminuindo a inclusão de usos e costumes que só aparecem dissolvidos na dinâmica dos acontecimentos.” (p. 8) ${ }^{98}$

\footnotetext{
96 "Prefácio” In: Memórias de um Sargento de Milícias. De acordo com Boris Fausto: “Ao transferir-se para o Brasil, a Coroa não deixou de ser portuguesa e favorecer os interesses portugueses no Brasil. Um dos principais focos de descontentamento nas forças militares. Dom João chamou tropas de Portugal para guarnecer as principais cidades e organizou o Exército, reservando os melhores postos para a nobreza lusa.” (História do Brasil, p 127). Os padres eram figuras obrigatórias nas festas públicas. Segundo Rodriguez Lopes: "os sermões estavam presentes em todas as comemorações dessa época, e muitas vezes eram a parte mais importante dos festejos, pois dependendo da ocasião só se realizava uma missa para celebrar determinado evento.Especialmente nos grandes festejos, como as Aclamações, um dos objetivos do sermão era o de articular discurso e arquitetura efêmera dando-lhe maior inteligibilidade. (...) A arquitetura efêmera e os sermões vinculavam-se a uma cultura marcada pela oralidade, visto que se entrelaçavam elementos visuais, orações pronunciadas na Igreja e leitura de panfletos ou de outros escritos em praça pública." (Festas públicas, memória e representação: um estudo sobre manifestações políticas na Corte do Rio de Janeiro, 1808-1822, pp. 69-70).

${ }^{97}$ Conforme Ralph Linton: "A fim de funcionar bem como unidade social, o indivíduo deve assumir certas formas estereotipadas de comportamento, ou melhor, certos padrões culturais." ("O indivíduo, a cultura e a sociedade” In: O homem e a sociedade, p. 101)

98 "O romântico fruto de uma pisadela e de um beliscão". In: Memórias de um Sargento de Milícias, 1992. A opinião da pesquisadora retoma um dos argumentos de Antonio Candido, segundo o qual "a primeira metade tem mais o aspecto de crônica, enquanto a segunda é mais romance, fortalecendo a anterior, preservando o colorido e o pitoresco da vida popular, sem situá-la, todavia, num excessivo primeiro plano.” (“Dialética da malandragem”, p. 30)
} 
Aceita a hipótese de que Leonardinho fosse uma personificação do Brasil ou do arquétipo "brasileiro", vale lembrar que o filho nasce e vive sem o referencial dos pais. É um jovem que se forma sem receber educação; que cresce sem amadurecer. É praticamente um órfão, apesar de os pais estarem vivos, bem vivos: a mãe, arranjada com um novo parceiro português; o pai, abraçado ao posto de meirinho. Como herdar caráter? ${ }^{99}$

\section{O vagal e o mandão}

É sugestivo que em 1856, ano seguinte à primeira edição das Memórias, Manuel Antônio de Almeida, por ocasião de uma publicação de seu amigo Francisco Pinheiro Guimarães (autor de $O$ Comendador), manifestasse sua revelia pelo típico mandão brasileiro:

"O tipo hediondamente original dos nossos mandões de aldeia, essa torpe idealização da perversidade, perversidade estúpida, grosseira, esquálida que traz sob a pressão de suas numerosas torpezas todo o interior de nosso país, amparada e sustentada pela outra perversidade inteligente, polida, dourada, que de longe a açula em seus maus instintos para fazê-la servir a seus fins mais indireta porém não menos friamente criminosos, de há muito que devia ter sido trazida às páginas imparciais e eloqüentes do romance. (...) o romance que os trouxer em toda a verdade de sua hediondez ao tribunal da consciência pública, será, quando não mais, uma página de santa vingança.” (p. 51)

No papel de crítico literário, o escritor se aproveita da resenha sobre o romance O Comendador para disparar, sem rodeios, severas restrições à articulação dos poderes em nossa sociedade, avizinhando-se de outro problema de feições similares: o coronelismo. $^{101}$

Ao ressalvar alguns esboços (desenhos mal formulados no romance que criticava) Almeida - numa manobra audaz - não só reconstruiu o atalho para a reescrita daquele. Lembra imediatamente suas próprias Memórias - romance que sofreu vários decréscimos na forma e alterações no conteúdo, comparado à versão em folhetim.

De certo modo, a resenha de 1856 vai ao encontro de seu romance, notadamente por abordar o papel dos “mandões de aldeia”, num ensaio de poucas páginas e muito fôlego, escrito a sério, sem a necessária (e aparente) leveza folhetinesca.

\footnotetext{
99 Segundo Walnice Nogueira Galvão, Leonardo-filho seria um “ancestral de Macunaíma”. Seu autor foi "o primeiro a fixar em literatura o caráter nacional brasileiro, tal como terá longa vida em nossas letras" ("No tempo do rei" In: Saco de gatos, p. 32).

${ }^{100}$ Correio Mercantil, 20/07/1856 (Obra dispersa, 1991).

${ }^{101}$ O ensaio de Manuel Antônio de Almeida valeria por si só, pelo que representa em forma e conteúdo, mas aqui interessa indicar outros dois fatores: 1) a possibilidade de dialogá-lo com seu próprio romance; 2) a probabilidade de estabelecer uma aproximação estilística com os escritos de Lima Barreto, como se pretende na terceira parte deste trabalho.
} 
Os estudos mais relevantes sobre seu romance, parecem focados mais estritamente sobre o tom de divertissement. Por esse motivo, embora tenham levantado teses empolgantes sobre a obra do escritor - em que é abordado o estilo de linguagem, a estruturação satírica do enredo, a caricatura radiografada nas personagens etc - não estudam com maior seriedade o que haveria de trágico nas patuscadas (para empregar um termo da época) do herói de avessos e demais figuras tamancudas e de baixa extração social. Acima de tudo, o romance foge intencionalmente às convenções romanescas da época. Na opinião de Berta Waldman:

"isento de qualquer traço idealizante, no romance não há lugar para as tintas sentimentais e heróicas nem para o abuso de peripécias inverossímeis, tão do gosto do romance romântico da época, que se comprazia em representar a vida do Rio de Janeiro enobrecida por uma retórica elevada e florida" (p. 9) $)^{102}$

De volta à apreciação da história. Numa bem urdida trama, Pataca e Hortaliça geram Leonardo, adotado por seus padrinhos de batismo. Não por acaso, Leonardo-filho seria criado por dois legítimos simplórios representantes da classe oscilatória de uma terra sem donos. País que não era nação e que, por isso mesmo, comportava um povo miscigenado em conseqüência dos feitos colonizadores (tráfico externo e interno, dependência econômica e política etc). Leonardo filho, sem país, sem pais, sem identidade. Testemunha dos desentendimentos entre seus inventores apressados, fora de hora.

“- Ó compadre, disse, você perdeu o juízo?... - Não foi o juízo, disse o Leonardo em tom dramático, foi a honra!... A Maria, vendo-se protegida pela presença do compadre, cobrou ânimo, e altanando-se disse em tom de zombaria: - Honra!... honra de meirinho... ora! O vulcão de despeito que as lágrimas da Maria tinham apagado um pouco, borbotou de novo com esse insulto, que não ofendia só um homem, porém uma classe inteira! Injúrias e murros à mistura caíram de novo sobre a Maria, das mãos e da boca de Leonardo. O compadre, que se interpusera, levou alguns por descuido; afastou-se pois à distância conveniente, murmurando despeitado por ver frustrados seus esforços de conciliador: - Honra de meirinho é como fidelidade de saloia.” (pp. 75-6)

Um dos ingredientes que embalam a leitura das Memórias é o gosto dos leitores pela peripécia - prazer que se reanima a cada reviravolta de nossas expectativas, sempre em favor de Leonardo-filho, por quem acabamos torcendo, de modo a escapar de Vidigal.

O major, aliás, protagoniza apenas dois ou três capítulos, na narrativa; mas é justamente a sua discreta menção por parte do narrador que não permite ao leitor esquecê-lo. É bem verdade que quando essa personagem aparece, Leonardo-filho

${ }^{102}$ Op. Cit. 
transparece: tem sua participação desbotada. A malandragem cede lugar ao marcapasso.

As estripulias de um e as prisões efetuadas pelo outro se alternam com episódios mais amenos, em que reinam a fofoca desbragada e as comemorações em torno de símbolos e personalidades tradicionais.

"Nesse tempo ainda não estava organizada a polícia da cidade, ou antes estava-o de um modo em harmonia com as tendências e idéias da época. ${ }^{103} \mathrm{O}$ major Vidigal era o rei absoluto, o árbitro supremo de tudo que dizia respeito a esse ramo de administração; era o juiz que julgava e distribuía a pena, e ao mesmo tempo o guarda que dava caça aos criminosos; nas causas da sua imensa alçada não havia testemunhas, nem provas, nem razões, nem processo; ele resumia tudo em si; a sua justiça era infalível” (p. 91)

O autoritarismo de Vidigal, é claro, diz respeito a uma marca da polícia, naquele tempo. Nesse sentido, o major acumula o papel de simbolizar os desmandos que os senhores da lei estavam autorizados a executar com a roupagem da manutenção da ordem.

A fluidez antevista nos processos de condenação (do cárcere ao exílio) estava ligada a uma sorte de anomia, esta mal escondida num dos vários tentáculos da confusa e onerosa administração real: o braço da proteção à ordem e, ao mesmo tempo, a manutenção do poderio de el-rei.

No livro, as intervenções de Vidigal, surpreendendo até mesmo o eterno fugitivo Leonardo-filho, não só dizem algo do sistema policial de verdade; relembram ao leitor, de tempos em tempos, a figura onipresente do poderoso chefe da guarda local.

No capítulo VIII, além de apontar a continuidade - na época da publicação do próprio romance - de certos elementos do tempo do rei (vide a construção do parágrafo inicial, em destaque) é revelada uma das causas para as falhas do policiamento, no Rio de Janeiro:

"Ainda hoje existe no saguão do paço imperial, que no tempo em que se passou essa nossa história se chamava palácio del-rei, uma saleta ou quarto que os gaiatos e o povo com eles denominavam o Pátio dos Bichos. Este apelido lhe fora dado em conseqüência do fim para que ele então servia: passavam ali todos os anos três ou quatro oficiais superiores, velhos, incapazes para a guerra e inúteis na paz, que o rei tinha a seu serviço, não sabemos se com mais alguma vantagem de soldo, ou se só com mais a honra de serem empregados no real serviço.” (p. $109)^{104}$

\footnotetext{
${ }^{103}$ O folhetim tinha redação diferenciada: “(...) ou antes estava-o de um modo que bem denotava o caráter da época” (p. 44, 2004).

${ }^{104}$ Para Nelson Omegna: "É impressionante o hábito de ser dar apelido ao homem da colônia (...) Essa freqüência de atar o homem ao ofício indica uma preocupação de grifar o contorno de classes.” (Op. Cit., pp. 137-8)
} 
Como se vê, a brincadeira de Manuel Antônio de Almeida, recuada um par de décadas, diz algo de verdadeiro sobre as rachaduras do jovem país-colônia. Seu alerta poderia ser esmiuçado na notável percepção de Faoro a respeito de outra confusão, esta na hierarquia luso-brasileira:

"A dispersão em todos os graus se agrava com o vínculo frouxamente hierárquico: todos se dirigem ao rei e ao seu círculo de dependentes, atropelando os graus intermediários de comando. Duas fontes de fluidez do governo: os órgãos colegiados e a hierarquia sem rigidez. O quadro metropolitano da administração como que se extravia e se perde, delira e vaga no mundo caótico, geograficamente caótico, da extensão misteriosa da América. Os juristas e burocratas portugueses, pobres de inspiração criadora - ao contrário dos escolásticos espanhóis, enredados na subtileza de especulações pouco práticas, e o dos colonizadores ingleses, desvinculados da teoria rígida - transplantam mais do que adaptam, exportam mais do que constroem. Flexibilidade colonizadora e hierática fixação de pensamento - esta a característica da armadura colonial, imposta ao flutuante, mutável e rebelde mundo atlântico. Vinho novo lançado em odres velhos, mas vinho sem capacidade para fermentar e romper os vasilhames tecidos por muitos séculos. O arbítrio, a desobediência, a rebeldia das autoridades coloniais, ao lado da violência, terão um papel criador, ajustando o vinho novo aos odres antigos, não raro desfigurados pelas pressões locais.” (pp. 203-4) ${ }^{105}$

Leitores simpáticos ao herói e anti-herói, às vezes esquecemos as mensagens do narrador, que ali cumpre o papel de dinamizar a história, mas também apontar os tênues limites entre o mando e o desmando, entre a vadiagem sem força e o poder da guarda que pouco protege e menos defende. Nas palavras de Mário de Andrade:

"se todos os personagens principais são estupendamente estudados com luz perversa, há que observar a sutil delicadeza, a verdadeira simpatia com que o artista expõe o Leonardo em sua personalidade curiosa de vadio perfeito e burro satisfeito.” (p. 135) $)^{106}$

Se Leonardo burla a ordem teórica das coisas, lá, as formas de poder - da repressão policial às demandas judiciais - estão vinculadas às desordenadas relações de amizade, amor e compadrio. Mas nem mesmo as rixas entre os habitantes (vide o barbeiro e sua vizinha) são elementos meramente risíveis: servem a ilustrar o gosto pela contenda. Sintoma da mania de pisarem uns sobre os outros tão logo surjam as oportunidades. Como observou Roberto Goto:

"O tom geral é de ironia branda, de censura simpática, favorecendo a leitura nos termos das mútuas compensações, sem todavia anular ou reverter os valores morais (...) A ambivalência moral deste narrador reflete uma ideologia do meio termo cujo foco atravessa o romance em vários níveis (...) o narrador esboça uma crítica social lembrando que já 'naquele tempo' (e dizem que é defeito do nosso) o empenho, o compadresco, eram uma mola real e de todo o movimento social, crítica que não chega a se completar no entrecho, ao qual todo tipo de empenho parecer ser bem vindo, e se legitima porque é o que resolve os problemas, impede a assunção de violências e manifesta a geral camaradagem que embala o romance e seu leitor.” (pp. 56-7) $)^{107}$

${ }^{105}$ Os donos do poder.

${ }^{106}$ Op. Cit.

107 “O narrador malandro" In: Malandragem revisitada. Segundo Miécio Táti: “Talvez Manuel Antônio de Almeida ainda tenha sido, pelo temperamento, o mais fiel representante do espírito do povo 
Ora, o poder de todos é flutuante, em reforço às ironias do narrador. Assim procedendo, ele se antecipa ao narrador machadiano de $O$ Alienista, pois como este “escapa à necessidade de descrever os objetos com propriedade e nitidez: a ironia não existe exclusivamente por existir (como tal traduz uma atitude de crítica a todo o pensamento e sentimento-clichê). Neste estilo, a ironia tem simultaneamente a função de ser um meio para ocultar, manter distância, e não marca posição.”108 Tudo a flutuar: Leonardo nasce num instante temporal e no intervalo físico, sugestivamente no mar, como se portasse desde sua concepção o dado da mobilidade, outro nome para a “reversibilidade” de que fala Antonio Candido.

A oscilação nos humores das figuras do romance - todos são personagens temperamentais - é realçada pela onipresença de Vidigal, mandão cuja tipificação parece intencionalmente abrandada pelo tom humorístico do escritor.

Leonardo-filho é cria sem pais; não reconhece o limite pátrio (pai, país) porque tem mais de uma mãe (outro papel da Comadre Parteira) e uma dupla de pais (Pataca e o Barbeiro). É o barbeiro sem muita instrução que lhe ensinará pela metade os rudimentos da escrita e de sua própria profissão, outro item a que Leonardo não se aplica. Será também seu principal aliado, inclusive na tramitação do amor do jovem ocioso pela prendada Luizinha - sobrinha da viúva D. Maria, mulher de posses amiga de seu padrinho humilde, mas não pobre, pois herdara impropriamente a fortuna de um marítimo.

No papel de mãe vem a Comadre, que, além de trazer o menino ao mundo é quem mais intercede no encaminhamento de determinados sucessos do afilhado sem rumo. As correções na rota do menino são manobradas pela sabida parteira e, é claro, acontecem pelo avesso, porque baseadas em novas burlas à ordem vigente, já que a ordem é por si mesma sempre passível de ser relativizada.

Ora, Leonardo sem-caráter, refratário à fixidez, apático diante da necessidade de ofício, é personagem que pode servir de representação do sujeito sem-lugar, Brasil. País que sobrevivia na lógica sem razão da colônia, num progresso a reboque, e de cara com o nosso provincianismo, re-atualizado a cada necessidade de colocarmos o famigerado “caráter nacional” à prova. Marques Rebelo induzira a questão de forma precisa:

"É interessante constatar que no Brasil, quem queira conhecer pormenorizadamente os nossos costumes e ambiente social do século XIX, tenha de apelar sistematicamente para o depoimento dos visitantes estrangeiros (...) porque os escritores patrícios nada nos mostram da vida real.

carioca, comunicativo, vivo, simpático e irreverente, sem a amargura racial que ressumbra das páginas de Lima Barreto.” (Estudos e notas críticas, p. 215)

${ }^{108}$ Wolfgang Kayser. Op. Cit., p. 201, Vol. 2 
Todos eles pairam numa atmosfera de sonho, de febril fantasia, de mataria cenográfica ou de alcovas de cetim escondendo virgens pálidas. Como única exceção temos Manuel Antônio de Almeida, que parece completar a obra de Debret.” (p. 49) ${ }^{109}$

A aproximação entre Pataca e Chiquinha (sobrinha da Comadre), sua terceira parceira em solo brasileiro, favorece novo trauma no reencontro com o filho, Leonardo, consolidando a definitiva incompatibilidade entre o meirinho português e o vadio brasileiro.

Se quando pequeno, o filho fora arremessado pelo chute do pai, quando adolescente sairá corrido de casa sob a espada erguida do próprio - espada de meirinho cuja inutilidade tenta saldar pelo avesso a incompetência do poder pátrio. Pai que não é; filho sem país. $^{110}$

As relações amorosas de Leonardo-filho não ficam atrás. Luizinha contrasta com Vidinha (cognome de mulher fácil?) e se aproxima, com as devidas ressalvas, de certas figuras femininas encontradas nos contos machadianos. Convencional, ela se casa placidamente com José Manuel, sorte de boa-vida sem escrúpulos que caíra nas graças e de boca nas finanças de D. Maria. A esse respeito remarcou Antonio Candido que:

"se Luisinha pode vir a ser uma esposa fiel e caseira, o mais provável é que Leonardo siga a norma dos maridos e, descendo alegremente do hemisfério da ordem, refaça a descida pelos círculos da desordem, onde o espera aquela Vidinha ou outra equivalente (...) Ordem e desordem, portanto, extremamente relativas, se comunicam por caminhos inumeráveis, que fazem do oficial de justiça um empreiteiro de arruaças, do professor de religião um agente de intrigas, do pecado do Cadete a mola das bondades do Tenente-Coronel, das uniões ilegítimas situações honradas, dos casamentos corretos negociatas escusas.” (p. 35) ${ }^{111}$

Providencialmente, o narrador enterra o primeiro marido da moça abastada e, não por acaso, a agora senhora prendada se unirá a Leonardo filho, brigado com Vidinha. Mas o casamento se dará somente quando este ocupar o posto de Sargento das milícias - obra máxima de Vidigal - absolutamente empenhado na soltura e recolocação do jovem desordeiro em paga à mancebia prometida por Maria Regalada, capricho, regalo seu.

Regalada, a terceira Maria da história, é mais fiel que a das Hortaliças e mais liberal que D. Maria, a tia de Luizinha. As mulheres, convém lembrar, é que “endireitam” os desvios de rota de Leonardo, através de atalhos nem sempre retos. ${ }^{112}$

\footnotetext{
109 Op. Cit.

${ }^{110}$ A “espada”, que aqui marca a drástica separação entre o poder pátrio e o filho rebelde, reaparece em $O$ Alienista, sob a forma de navalha. Cf. Chevalier: "a espada é o símbolo do estado militar e de sua virtude, a bravura, bem como de sua função, o poderio (...) emblema do rei.” (Dicionário de símbolos, p. 392)

111 “Dialética da malandragem”.

${ }^{112}$ Como observou Roberto Goto: “o itinerário do herói envolve a trajetória prosaica do pequeno burguês que ao mesmo tempo fica rico e se casa com moça branca, direita e boa herdeira, não sem antes aprender
} 


\section{Festival simbólico}

Ao reunir as numerosas personagens de seu romance, Manuel Antônio de Almeida aproveitou-se da descrição de várias celebrações populares. Tudo é motivo para festa, naquele romance - sejam elas procissões cristãs (sob as ordens do padre infiel a Deus e amigado da Cigana) ou celebrações pagãs (sob a desordem dos ciganos) - o que contribui para revelar o caráter híbrido das crendices e o tom de bandalheira dos eventos, em tese levados a sério, com direito aos tapetes nas fachadas, ramos de arruda e o infalível terço na ponta dos dedos.

Tais festas populares preenchem o ócio das classes de baixa extração e apontam para o poder da cultura popular - talvez como alternativa à cultura erudita artificialmente importada. Permitem ao narrador marcar os territórios em correspondência com as figuras de diferentes extrações sociais; tipificar as personagens do romance num valioso jogo de resgate e estabelecer rupturas entre uma época e outra.

A opulência das festas, como se vê, destaca também o pernicioso contraste entre o luxo do poder real e a simplicidade dos enfeites populares.

A comadre, que deu luz a Leonardo - aquele sem pais e sem país, porque concebido no vácuo histórico e geográfico entre Portugal e o Brasil - é uma personagem-chave do livro. Mulher que entre um parto e outro se ocupa de missa, reza e fofoca, iguala-se às figuras femininas de seu tempo, não somente devido ao apego estrito à religião e à vida alheia, mas de forma caricata, pela estrutura física, completada pela vestimenta, mais especificamente a mantilha.

"Era a comadre uma mulher baixa, excessivamente gorda, bonachona, ingênua ou tola até um certo ponto, e finória até outro, vivia do ofício de parteira, que adotara por curiosidade, e benzia de quebranto; todos a conheciam por muito beata e pela mais desabrida papa-missas da cidade.” (p. 103) ${ }^{113}$

De fato, a mantilha da comadre simboliza o costume de transplantar objetos e modas para o Brasil. Tendência de supervalorizar o que houvesse para ser importado. Costume artificial e artificioso que serve, em tom ameno, a advertir o leitor para o fato de que não somos mais do que caricaturas - é bem verdade que uns com maior

\footnotetext{
a lidar com o sexo oposto através de aventuras com mulheres de outra composição étnica e extração social mais baixa." (Malandragem revisitada, p. 61).

113 “Em 1775, Martins Lopes Lobo de Saldanha, governador de São Paulo, se implica com os disfarces das baetas usadas como rebuço, que Luccock afirma ser em Diamantina, um instrumento de nivelação social, pois debaixo delas não se consegue saber a categoria e condição econômica da mulher. (...) a moda persistiu, mudada só a baeta em mantilha. Novas ordens são enviadas, em 1780, a diversas vilas, como Santos, Campinas e Sorocaba, proibindo terminantemente andarem as paulistas de mantilhas e josezinhos ‘cobrindo o rosto, inteiramente rebuçadas. (...) a mantilha resiste e prossegue até 1810.” (Nelson Omegna, Op. Cit., pp. 141-2)
} 
capacidade de imitação que outros.

"Este uso da mantilha era um arremedo do uso espanhol; porém a mantilha espanhola, temos ouvido dizer, é uma coisa poética que reveste as mulheres de um certo mistério, e que lhes realça a beleza; a mantilha das nossas mulheres, não; era a coisa mais prosaica que se pode imaginar, especialmente quando as que traziam era baixas e gordas como a comadre. A mais brilhante festa religiosa (que eram as mais freqüentadas então) tomavam uma aspecto lúgubre logo que a igreja se enchia daqueles vultos negros, que se uniam uns aos outros, que se inclinavam cochichando a cada momento.” (p. 105)

Como tudo caminha na oscilação entre a ordem e a desordem, nem o local sagrado impede o falatório, outro, o da vida alheia. E é no espaço público (na rua ou na Igreja) que os mesmos fofoqueiros fora de lugar recorrem à palavra de Deus, ao sagrado com força de religião, para justificar determinados atos ou tentar brecar certas atitudes em desacordo com a opinião pública.

E como tudo é incerto, não é à toa que Leonardo, apesar de viver desde cedo sob as parcas instruções do barbeiro, mais atrapalha o padrinho que aprende o ofício. Ser barbeiro exigiria responsabilidade de profissional e precisão no manejo da navalha elementos que o garoto não sabe ou não deseja manipular. Acima de tudo, a barbearia está ligada à tradição, como comprovam as circunstâncias relacionadas à origem do próprio barbeiro:

"Se alguém perguntasse ao compadre por seus pais, por seus parentes, por seu nascimento, nada saberia responder, porque nada sabia a respeito. Tudo de que se recordava de sua história reduzia-se a bem pouco. Quando chegara à idade de dar acordo da vida achou-se em casa de um barbeiro que dele cuidava, porém que nunca lhe disse se era ou não seu pai, ou seu parente, nem tampouco o motivo por que tratava da sua pessoa.” (p. 113)

Como se percebe, não é somente Leonardo - de cujos pais temos alguma notícia - que vive sob o regime da semi-orfandade. Embora o narrador revelasse um dado de época (filhos humildes que desconheciam a identidade dos pais, estes em geral lusitanos), e em apoio à idéia de que Leonardo filho pudesse ser uma alegoria do Brasil, uns e outros viveriam entre a identidade e a falta de identidade, devido à falta de referencial. Se não se sabe da origem, o que esperar do caminho que emenda a seguir?

Por seu turno, a comadre não só era talentosa nos partos, mas detinha uma poderosa memória, devotada aos eventos de cunho religioso. Se o barbeiro era destro no uso da navalha e apto a fazer uma boa sangria, a comadre tem lá outro dote precioso:

"Era a folhinha mais exata de todas as festas religiosas que aqui se faziam; sabia de cor os dias que se dizia missa em tal ou tal igreja, como a hora e até o nome do padre; era pontual à ladainha do terço, à novena, ao setenário; não lhe escapava Via Sacra, procissão, nem sermão; trazia o tempo habilmente distribuído e as horas combinadas”. (p. 103)

\footnotetext{
${ }^{114}$ Para Nestor Duarte: "É, porém, a Igreja, ainda assim, a única que consegue, por vezes, preencher o espaço vazio entre a família e o Estado no território da Colônia." (A ordem privada e a organização política nacional, p. 76)
} 
Ora, a navalha está ligada diretamente à profissão de barbeiro. A título de curiosidade, vale lembrar a notável polissemia que a palavra "sangria” adquire ao longo do romance, particularmente no capítulo dedicado ao “Arranjei-me do compadre". Morto o marujo a que servira durante uma longa viagem em alto-mar, o barbeiro decide herdar impropriamente a fortuna deixada pelo marítimo, devolvendo no próprio gesto de apropriação indevida os serviços de sangria que prestara à tripulação do navio.

De qualquer forma, são as rendas dos ofícios de compadre e comadre que, bem ou mal, amparam Leonardo-filho, durante sua criação postiça. E como sua criação fora promovida à prestação - porque mais ou menos de acordo com os intervalos (ou seja, quando o jovem não estava metido em peraltices) - é de se observar que Leonardo opera a sua própria “descriação”, o que faz balançar mais uma vez a noção de família.

É que não se constitui família, no romance. Provam-no o pronto relacionamento enjeitado por Maria da Hortaliça que, tão logo encontrada em terra firme, abandona o já traído marido e enamora-se de um marujo lusitano. Comprovam-no os sucessivos concubinatos do Pataca, que assiste a mais de um de seus relacionamentos serem rompidos pelos mesmos motivos.

Nem mesmo Luizinha escapa a dois casamentos, o primeiro com José Manoel que ganhara a confiança de Maria, a tia, e de quebra a aliança, por obra de sua retórica de velhaco; o segundo, com o recém empossado sargento de milícias (e, a julgar pelo andamento de Leonardo, nada assegura que o jovem traquinas tivesse feito as pazes com as instituições, de um modo geral).

A mantilha da comadre estava ligada à vestimenta de sair à rua, no caso, para visitar os outros e assistir a missas. Como imitamos a religião e os modos dos europeus, e aqui as coisas funcionam de forma canhestra, não parece tão distante um fato do outro. Já que não somos cópia infiel do original, nosso modelo permite o deslize. Por isso, não só a mantilha não assenta no físico da comadre, como ilustra o meio-termo a que são submetidos até mesmo os rituais sagrados. Segundo Carmen Lúcia de Figueiredo:

"o uso deslocado [da mantilha] é extremamente conveniente, necessário para uma sociedade cujas regras, valores e instituições pautam-se pelo dúbio, ambíguo. Viver nesse contexto exige a sabedoria de transitar entre perigosos opostos - razão/desrazão, lei/marginalidade, ordem/caos sem se deixar tragar nem pelo ridículo, nem pelo trágico. Uma sabedoria que o narrador machadiano colocará em prática e a observação do exercício dessa sabedoria, na vivência dos brasileiros comuns, marcará o perfil dos personagens de Lima Barreto.” (p. 55) ${ }^{115}$

Outra peça do vestuário que ganha relevo, no romance, são as ceroulas com que é surpreendido o major Vidigal, quando da visita da Comadre, na comissão cujo papel

\footnotetext{
${ }^{115}$ Trincheiras do sonho - ficção e cultura em Lima Barreto.
} 
central é desempenhado por Maria, a Regalada (caso do policial). Ser pego de calças curtas, no caso de Vidigal, literalmente falando, implica que a autoridade - maior quando o major se encontra fardado - tenderia a escorregar. Se o representante do poder supremo falha, tudo volta ao início.

E, para reforçar a idéia de que a vida é ciclo, o narrador encerra o romance comunicando a morte da comadre e do compadre barbeiro, como se dissesse que os caminhos de Leonardo seriam traçados, a partir de então, ao lado de Luzinha: raro símbolo de correção. ${ }^{116}$

Já que tudo pode oscilar, a própria leitura do romance está sujeita a uma constante reavaliação. Em prefácio à edição francesa do romance, Paulo Rónai comentou com agudeza que:

"comme il se pique de ne pas donner dans les exagérations du romantisme, qui regrette toujours le passé, il explique son intérêt pour lê vieux temps d'une manière plutôt inattendue, en alléguant à plusieurs reprises que, s'il evoque les anciennes coutumes, ce n'est que pour prouver qu'elles n'ètaient pas supérieures aux coutumes nouvelles.” (p. 10) ${ }^{117}$

Enquanto na absoluta maioria dos romances do período romântico o amor apresentava-se como tema associado ao patrimônio e a forma romanesca vinha respaldada nas longas descrições de personagens e respectivos ambientes, nas Memórias de Manuel Antônio de Almeida a afeição entra em meio às manobras e peraltices para desnudar o desequilíbrio ou a falta de solidez das novas instituições. Conforme Josué Montelo:

"Numa época em que era de bom tom falsear a realidade para embelezá-la, Manuel Antônio de Almeida pinta os seus tipos e descreve as suas cenas sem as deformações do Romantismo ainda em moda em nossa literatura" (p. 39) ${ }^{118}$

Curiosamente, é o amor - bem ou mal resolvido - que motiva as três uniões de Pataca (Hortaliça, Cigana e Chiquinha), as duas de Leonardo-filho (Vidinha e Luizinha), o segundo casamento de Luizinha (José Manoel e Leonardinho) e o jeitinho (via Maria-Regalada) com que o Major anula os impedimentos para o casamento de Leonardo-filho, agora sargento por conveniência e pouco mérito, ao agrado de nossa torcida. Parece haver uma correspondência entre o novo sargento Leonardo e os trajes

\footnotetext{
116 “Leonardo”, do alemão antigo: de coração valente; “Luizinha”, do germânico: sábia, eminente.

117 "Préface” In: Mémoires d’um sergent de la milice. Versão para o francês, de Paulo Rónai. (*como ele se gaba de não se levar pelos exageros do romantismo, que habitualmente se queixa do passado, explica seu interesse pelos velhos tempos de uma maneira inesperada, alegando em várias tomadas que se ele evoca os costumes antigos é justamente para provar que não eram superiores aos novos costumes.”)

118 “Um precursor: Manoel Antônio de Almeida” In: Afrânio Coutinho; Eugênio Gomes e Barreto Filho. A literatura no Brasil, 1955.
} 
com que se veste muito à vontade o Vidigal $^{119}$, dono de seu destino. Leonardo vive ao sabor dos relativos censores alheios, como disse Eliane Zagury em uma apresentação ao romance:

“O protagonista Leonardo é um indivíduo de personalidade muito pouco marcada. Guiado por certa habilidade intuitiva, desempenha seus atos, que são mais confusos que problematicamente conflitados. Abandonado de pai e mãe, parece ter a compensação de ser o bem-amado de todos os demais, por gratuita simpatia. Não é bom nem mau, como todos no livro.” (p. 6) ${ }^{120}$

É o amor mais e menos volúvel que, por fim, direciona o sem-norte percebido por Antonio Candido em meio à “dialética da ordem e da desordem”. E é o amor, ainda, que favorece o passe-livre de Leonardo-filho por entre as diferentes classes sociais: da barbearia à sacristia; da casa da rica viúva à ucharia real; da fila de soldados à prisão; da prisão para as milícias.

O percurso instável de Leonardo tem gosto e cor de fatalismo, como percebeu Antonio Candido e confirmou Roberto Goto: "Ser flexível, no caso do malandro Leonardo, é um dado de temperamento mas também uma imposição das circunstâncias e do aprendizado social, e esta flexibilidade não deixa de carregar um aspecto de mutilação do indivíduo” (p. 72)

Leonardo, feito quase por acaso, em valente disposição contra a estabilidade. Sorte de alegoria de um país que vive em situação controversa. Nome de "um brasileiro", possível segundo significado do subtítulo colocado na capa, na primeira edição do romance.

\footnotetext{
${ }^{119}$ A certa altura, Leonardo (o pai) também se veste em desacordo com o ambiente: “o Leonardo, instado pelas senhoras, decidiu-se a romper a parte lírica do divertimento. Sentou-se num tamborete, em um lugar isolado da sala, e tomou uma viola. Fazia um belo efeito cômico vê-lo, em trajes de ofício, de casaca, calção e espadim, acompanhando com um monótono zunzum nas cordas do instrumento o garganteado de uma modinha pátria.” (MSM, p. 69). Segundo Roberto DaMatta: “o traje formal, como a farda, opera por meio de uma individualização ou de um modo analítico, segregando rígida e nitidamente um papel de outros (desempenhados por uma mesma pessoa), ao passo que a fantasia opera sinteticamente, por união, somando um papel imaginário (expresso na fantasia com os papéis 'reais' que a pessoa desempenha no mundo cotidiano)." (Op. Cit., p. 61)

120 “Apresentação” In: Memórias de um Sargento de Milícias.

${ }^{121}$ Op. Cit.
} 
PARTE II - PREPOTÊNCIA 


\section{Machado de Assis: capítulo à parte}

"[A comicidade] é um fenômeno que entra na classe de todos os fenômenos artísticos que denotam no ser humano a existência de uma dualidade permanente, a faculdade de ser ao mesmo tempo um e outro.” (Charles Baudelaire) ${ }^{122}$

\section{Dois focos}

O Alienista $^{123}$ ocupa lugar de destaque na ficção machadiana, malgrado a existência de claras controvérsias por parte da crítica, quanto a sua recepção: é que muitos leitores tendem a dividir o enfoque e por vezes perder o eixo diante do mirabolante enredo e seu potencial histórico-alegórico. Dizia Augusto Meyer:

"toda a arte de Machado está concentrada nas reticências, no magnetismo das sugestões que enfeitiçam o leitor. O Alienista, sob a sua aparência leve e um tanto caricata, encobre a sátira mais feroz de toda a sua obra e, ultrapassando pelo sentido íntimo os seus modestos limites, dando uma ressonância inédita ao humour” (p. 62)

A trama é das mais rocambolescas, o que pode levar a depreciar os vários recados do autor, mal escondidos no estilo de seu narrador. Eugênio Gomes advertia, em $1958^{125}$, que [Machado] "não foi um praticante da arte pela arte (...) nesse escritor, o contista explica o romancista, no qual por vezes se desdobra”. ${ }^{126}$

O Alienista é perfeita amostra da cuidadosa elaboração envolvida em suas composições de maior fôlego. Concordo com a opinião de Candido Jucá Filho:

"Psicólogo profundo, ele soube aproveitar da maneira mais inteligente as diversas atitudes e as diversas situações de suas personagens. Afetando a máxima simplicidade, os seus livros são extremamente complexos. Os capítulos afiguram-se-nos às vezes fragmentários. Mas são 'manchas' de impressionista, que se hão de casar pela crítica psicológica e pela ironia que encerram.” (p. 119)

\footnotetext{
${ }^{122}$ Lo cómico y la caricatura, p. 51

123 Segundo Luiz Costa Lima (1976): “O Alienista alcançou repercussão quase imediata. Inquérito realizado entre setembro de 1893 e janeiro de 1894 indicava-o candidato - é certo que menos votado - ao posto de melhor conto brasileiro.” (p. 26) - Revista José, n. 3.

${ }^{124}$ Machado de Assis.

${ }^{125}$ Aspectos do romance brasileiro, p. 84.

${ }^{126}$ José Emílio Major Neto, em Introdução à novela, raramente mencionada pelos estudiosos, acertara a mão ao afirmar que: "O primeiro aspecto relevante desta obra (...) é o seu enredo cheio de peripécias e suas reversões. O tempo todo a máquina narrativa posta em circulação por Machado nos absorve, desejamos avidamente atingir a sua conclusão, o que a torna ainda mais desconcertante e impactante. Além disso, nossas expectativas básicas em relação ao desfecho e condução esperável da ação narrativa vão sendo desfeitas por uma série de reviravoltas extraordinárias, e por demais estranhas, apesar do agudo sendo de humor que percorre a obra como um todo, submerso na dicção entre afetada, pernóstica e arcaizante do narrador." ("O Alienista de Machado de Assis” In: O Alienista, p. 67). Conforme Raymundo Magalhães Júnior, a novela "é antes de tudo, movimento, ação, vida que flui e, exatamente como ocorre nas peças de teatro, os acontecimentos é que explicam o caráter das personagens, em vez de ser esse caráter que os explica.” (A arte do conto, p. 177). Segundo Kayser: “a novela tende à concentração. Como o drama, mostra-se interessada na tensão horizontal e no decurso, do princípio ao fim, dum acontecimento.” (Op. Cit., p. 277)
} 
Em tom de anedota pseudo-histórica, a narrativa se assemelha a um ensaio literário, um aparente divertissement que ganha maior relevo justamente por tratar de forma brejeira temas absolutamente envolventes, como o poder da ciência, as arbitrariedades políticas, mais loucura, vaidade e egoísmo. Como se vê, tópicos muito produtivos na ficção machadiana. A suposta isenção moral deste narrador em terceira pessoa só se repetiria no romance Quincas Borba. Como observou Antonio Candido:

"se a fantasia funciona como realidade; se não conseguimos agir senão mutilando o nosso eu; se o que há de mais profundo em nós é no fim das contas a opinião dos outros; se estamos condenados a não atingir o que nos parece realmente valioso -, qual a diferença entre o bem e o mal, o justo e o injusto, o certo e o errado? Machado de Assis passou a vida ilustrando esta pergunta." (p. 33)

A opinião de Candido corrobora a impressão de Massaud Moisés:

"O certo é que o conto nos varre a mente e a sensibilidade como se fosse um golpe de vento que nos desalinhasse, obrigando-nos a recompor as vestes desarrumadas, ao mesmo tempo que nos dá uma sensação irreprimível de ridículo, pois não podemos fugir de nos ver retratados nas personagens que passeiam sua loucura mansa ao longo do conto. (...) O mistério que ronda uma história de absurdos permanece depois que a história se esgota (...) E, ao fim, tudo quanto é modo de ser, para melhor ou para pior, merece um rótulo, o que significa que ninguém está isento de ter alguns desvios de personalidade” (pp. 174-5) ${ }^{129}$

Dada a expressiva quantidade de sugestões, o leitor pode perder a mira e esquecer alguns fulcros. A novela combina os eventos de Itaguaí à Revolução Francesa $^{130}$ e não permite descartar os possíveis vínculos pelo avesso entre as figuras da vila e o elenco da Conjuração Mineira, por exemplo; ou ainda, a aproximação de Simão Bacamarte de várias personalidades da história universal. Dando razão a Dirce Côrtes Riedel:

"Na paródia, a palavra tem uma orientação dupla - em direção ao objetivo da narrativa, enquanto que palavra comum, e em direção a uma outra palavra, o falar de um outro. (...) $\mathrm{O}$ texto de Machado é quase sempre baseado na paródia. No entanto, o narrador, sempre ambíguo, parodia ao mesmo tempo que negaceia o conflito das duas vozes. Fica ambivalentemente, entre a paródia e a estilização, sem se pronunciar por uma nem por outra.” (p. 6) $)^{131}$

O escritor trazia em forma de piada alguns dos arbítrios da psiquiatria oficial ${ }^{132}$, como observou Alfredo Bosi. Por outro lado, a dupla Simão/Crispim constitui provável

\footnotetext{
${ }^{127}$ O pensamento e a expressão em Machado de Assis.

128 "Esquema de Machado de Assis” In: Vários escritos. Para Flávio Loureiro Chaves “a falência dos valores éticos é um núcleo estrutural subjacente à ideologia machadiana.” ( $O$ mundo social do Quincas Borba, p. 46)

129 “Notas preliminares” In: Memorial de Aires/O Alienista.

${ }^{130}$ O próprio título dos capítulos (“O Terror” e “Restauração”) assim o revela.

${ }^{131}$ Metáfora, o espelho de Machado de Assis.

${ }^{132}$ Bem observou José Leme Lopes a esse respeito que: “Ao classificar os doentes em furiosos e mansos, ao relatar as subclasses e ao relacionar, na segunda fase da atividade científico-doutrinária de Simão
} 
paródia das duas famosas figuras de Cervantes, como percebera Massaud Moisés, já em 1961. O tom é brando, a comicidade é evidente, mas a brincadeira desvela o absoluto poder de excluir, selecionar e julgar, inclusive a si mesmo. Cabe a advertência de Foucault:

"Sem dúvida, entre as formas da razão e as formas da loucura, grandes são as semelhanças. E inquietantes: como distinguir, numa ação prudente, se ela foi cometida por um louco, e como distinguir, na mais insensata das loucuras, se ela pertence a um homem normalmente prudente e comedido? (...) Não há razão forte que não tenha de arriscar-se à loucura a fim de chegar ao término de sua obra.” (pp. 34-5)

As referências mais ou menos explícitas à Revolução Francesa ${ }^{134}$ permitem suspeitar que o narrador se vale dos dados históricos como estratagema para satirizar a canhestra revolução mal conduzida em Itaguaí, inócua e sob a liderança de uma espécie de Tiradentes interiorano às avessas, obcecado por qualquer posto - de vereador a líder revolucionário - que lhe possibilitasse degustar sensações e poderios algo próximos daqueles assegurados por Bacamarte a si mesmo. Tem razão Barreto Filho:

“O poder público sufoca as reações populares, em nome da ciência, aliando-se ao delírio raciocinante do sábio. A religião, encarnada no Padre Lopes, desempenha em vão o seu papel de lutar pelo bom senso, afrontando os excessos do racionalismo, mas a tragédia coletiva prossegue (...) Quem conhece a nossa complacência por tudo o que se revista de uma aparência científica, a nossa facilidade em nos empenharmos em tentativas improváveis, quem observa a fragilidade de nossas resistências em face das teorias improváveis (...) o nosso gosto pelas panacéias, sabe o que Machado de Assis queria estigmatizar na forma alegórica dessa novela.” (pp. 112-3)

A recepção da novela, razoavelmente numerosa, pode ser re-agrupada em três ou quatro focos de leitura mais relevantes: as de Luiz Costa Lima e Alfredo Bosi - este a resgatar a leitura de teor psicológico de Augusto Meyer bem como as teses da biógrafa Lúcia Miguel Pereira, ao traçar interpretações sobre as perspectivas de cada tipo social, conforme seu posto de observação; de Pierre Brunel ${ }^{135}$, em ensaio especialmente

Bacamarte, os modestos, os tolerantes, os verídicos, os símplices, os leais, os magnânimos, os sagazes e os sinceros, não estaria o espírito satírico de Machado de Assis reproduzindo o exagero e a relativa arbitrariedade do furor classificatório da medicina mental do século XIX?” (p. 26) (A psiquiatria de Machado de Assis). A opinião do estudioso brasileiro seria reformulada por Pierre Brunel, por ocasião da tradução do conto para a língua francesa, em 1984 (L’Aliéniste). De acordo com Boris Schnaiderman: "Há passagens no conto que fazem pensar numa clarividência histórica assombrosa em Machado. É o caso daquela atitude da Câmara Municipal de Itaguaí, aprovada por instigação do cientista, que autorizava o uso de um anel de prata no polegar da mão esquerda a todo habitante que declarasse ter sangue godo nas veias. Ora, O Alienista é contemporâneo da teorização racista de Chamberlain, Gobineau e certos antropólogos alemães. (...) O espantoso, realmente, é a sensibilidade com que Machado percebeu aonde essa preocupação ‘científica’ poderia levar.” (“O Alienista, um conto dostoiveskiano?” Revista Teresa, 6/7, 2006, p. 272).

${ }^{133}$ História da loucura na Idade Clássica.

${ }^{134}$ Afirmação de Pierre Brunel: “Les Canjicas sont les sans-culotte de la raison menacée” (Op. Cit., p. 20

* “Os Canjicas são os sem-culote da razão ameaçada”).

${ }^{135}$ As observações de Brunel fazem coro à advertência de Luiz Ribeiro do Valle em Psicologia mórbida na obra de Machado de Assis: "O alienista é de todo indiferente ao que não se relaciona à sua 
dedicado ao texto publicado na França, concedendo a Itaguaí o estatuto de palco para a representação do teatro de todo o mundo; de Roberto Schwarz e Raymundo Faoro, que aproximam o comportamento oscilatório das personagens ao padrão das classes brasileiras; de John Gledson ${ }^{136}$, que elegeu certas obras machadianas para ilustrar de determinados períodos históricos brasileiros. Cabe a síntese de Faoro:

“Todos, para encenar o papel exterior, se mascaram (...) Todos renegam e todos se vingam. A ordem social se apura, filtra-se e se decanta, no fundo, com o exercício da vingança (...) o temor da obscuridade, o abismo da obscuridade é um dos motivos-chaves de Machado, coerentemente com a concepção da sociedade como alma exterior, animada de glória e brilho.” (pp. 340 e 501).

Incluam-se as leituras de outros críticos: militantes como Astrojildo Pereira ${ }^{137}$; médicos como José Leme Lopes e historiadores da literatura, entre eles Massaud Moisés - que estabeleceu a produtiva aproximação entre O Alienista e Dom Quixote -; mais Brito Broca, um dos primeiros a defender com riqueza de argumentos a posição político-histórica de Machado. A analogia de Bacamarte e o boticário Crispim com a dupla Quixote e Sancho Pança foi também sintetizada por Manuel Cavalcanti Proença: "É no cenário de uma cidade pequena, onde o convívio obrigatório revela o lado egoístico e mesquinho dos atos humanos, que pratica e expande a sua ciência o Dr. Simão Bacamarte, de loucura mansa como o Quixote, mas por antonímia, pois que o racionalismo, e não o devaneio é que o leva ao desatino. Nem lhe falta o Sancho, na figura do farmacêutico, que se aproveita da amizade para empregar parentes e insinuar a própria esposa e um sobrinho na comitiva de madame Bacamarte, em viagem de recreio.” (p. 13) ${ }^{138}$

Se não temos clara a noção dos limites entre nossos domínios e o dos outros, como reconhecer-nos e classificar os demais? A loucura, em O Alienista, aponta uma síndrome que cuida do limiar entre a identidade e seu contrário - aplicável não exclusivamente ao universo miniaturizado de Itaguaí.

O mesmo tema parece sugerido no romance de Manuel Antônio de Almeida e seria motivo de cenas patéticas, quando não trágicas, na pena de Lima Barreto. A questão não é ser ou deixar de sê-lo; é manter-se.

especialidade, isto é, à sua idéia fixa” (p. 143). Para o crítico francês, "tudo gira em torno do próprio alienista”.

${ }^{136}$ Diz John Gledson: "Machado encontrou (...) saídas menos drásticas, que quase sempre implicam não levar as coisas a sério, tratando-as com desrespeito bem-humorado ou sarcástico: é o caso, inclusive, do próprio tema da loucura naquele que talvez seja seu melhor conto, O Alienista." (Contos: uma antologia, p. 28)

${ }^{137}$ Astrojildo terá sido um dos primeiros a destacar duas balizas do estilo machadiano: "O seu método de composição é um misto de cálculo e de espontaneidade: a trama de ficção, o desenvolvimento das situações, o encadeamento dos caracteres, a reação psicológica dos personagens, o desenlace dos conflitos - tudo isso se processa obedecendo a cálculos minudentes e seguindo ao mesmo tempo uma linha de absoluta espontaneidade na fixação da narrativa no papel." (Machado de Assis - ensaios e apontamentos avulsos, p. 110).

138 “Introdução” In: O Alienista e outras histórias. Ediouro, s/d. 


\section{Quatro loucos}

O período de 1881-1991 reúne quatro figuras machadianas das mais relevantes. Tanto Memórias Póstumas de Brás Cubas, quanto O Alienista e Quincas Borba convidam o leitor não só a se deliciar com os enredos, mas a reexaminar as articulações ainda mais complexas tramadas ou sofridas por suas personagens, tentando-nos, por vezes, a repetir a pergunta sugerida por Constancio Alves: afinal, porque há tantos loucos nas páginas de Machado ${ }^{139}$ Augusto Meyer intuíra uma reposta convincente, ao abordar O Alienista:

"quem entra no reino do absurdo, não pode afirmar coisa alguma, porque o absurdo é um petardo formidável que acaba com este mundo e os outros, despedaçando a lógica, seu fundamento. Todos nós somos pobres escravos do princípio de identidade. (...) O humorista transcendente não grita, ele ri. Mas o seu riso será outra forma de protesto, um modo de refugiar-se na loucura do absurdo, dinamitando este universo criado pela nossa fatalidade determinista. (...) O humorismo transcendente desconhece as limitações do mundo ético, está muito além do mal e do bem, pois cortou as amarras que o prendiam à solidariedade humana." (pp. 58-9) $)^{140}$

Se nos primeiros quatro romances e dois livros de contos o autor dedicara maior atenção à caracterização das personagens, a partir das Memórias Póstumas de Brás Cubas e da coletânea Papéis Avulsos, temas mesquinhos como a sede de nomeada, o bovarismo fora de hora e lugar e o enriquecimento por todos os meios convertem-se em particularidades que não só tipificam determinadas personagens - mais refinadas e cruéis que aquelas da fase anterior - mas inauguram a ambição do escritor em tratar de forma burlesca determinados vícios e virtudes em escala universal. ${ }^{141}$ Segundo Eugênio Gomes:

“Alguns contos de Papéis avulsos (1882) e de Histórias sem data (1884) (...) revelam que, no período iniciado com as Memórias póstumas, o escritor estava, em conseqüência daquele vezo, excessivamente dominado pela preocupação de filosofar, embora quase sempre com intuito humorístico ou simplesmente irônico. Sua ficção desde aí regorgita de idéias e teorias.” (p. $99)^{142}$

Talvez por esse motivo, temas como o adultério, a loucura, a ganância, o egoísmo e o ciúme caminhem de forma tão coesa. Some-se aos pequenos grandes vícios

\footnotetext{
139 “Todos são mais ou menos loucos. Maluco é Braz Cubas. Maluco é Quincas Borba. Maluco é Rubião. A obra do romancista parece-me que poderia sem impropriedade, ser representada em resumo por aquele hospício de Itaguahy (...) Doidos, doidos, todos doidos. Mas porque a Machado de Assis repugnava a violência, o alarido, o excesso, mesmo na loucura, todos os seus loucos são mansos” (Figuras, p. 45)

${ }^{140}$ Machado de Assis.

${ }^{141}$ Nas palavras de Oscar D’Ambrósio: "Itaguaí é apenas o microcosmo criado por Machado para desnudar aspectos do ser humano presentes em todas as cidades e países" (p. 121). ("O desalienante realismo de Machado de Assis” In: Almeida, Arlenice et al. A supremacia do conto). Pierre Brunel, dez anos antes cognominara Itaguaí como "teatro do mundo".

${ }^{142}$ Aspectos do romance brasileiro.
} 
a petulância divertida de um Brás Cubas, ${ }^{143}$ que pode bem representar a sociedade imatura, por se formar - sociedade refletida na própria inconstância política, como induzia Brito Broca:

"Tudo nos seus romances e contos está ligado a uma realidade concreta, às flutuações do meio fluminense, aos usos e costumes da época, sob o signo das instituições. Como admitir num espírito em tais condições, num ficcionista que só trabalhava na matéria viva do ambiente social, a indiferença pelos acontecimentos políticos?” (p. 13) ${ }^{144}$

As sagas de advogado sem banca (Brás Cubas), psiquiatra internado (Simão Bacamarte) e professor desumanizado (Rubião) parecem tomar por empréstimo um recurso, na forma similar àquele empregado por Manuel Antônio de Almeida. Ponto em comum, a expectativa das reviravoltas é que motiva a atenção dos leitores. Reviravoltas que parecem se contrapor ao estilo elevado de Machado. Paródias de temas graves: ingredientes a desmoralizar as picuinhas sociais e politicagens em solo brasileiro, tomando a própria arte literária, refém de si mesma.

Logo, o tom de Machado não é puramente jovial ou folhetinesco. O potencial alegórico mereceu diversas abordagens por parte da crítica especializada. ${ }^{145}$ Mas, dentre as vias de acesso à obra machadiana, pouca atenção foi dada à simbologia, recurso que também se pretende explorar neste capítulo.

A personagem doutor-cientista nasceu praticamente na mesma época do advogado Brás Cubas e do filósofo Quincas Borba. Com eles integra um trio multifacetado, já que constituído por um rico ocioso (Cubas), um filósofo sem renda certa que defende a luta pela sobrevivência às expensas alheias e um médico que se aliena: conjunto que, a bem da verdade, mais faz pseudo-teoriza do que trabalha e, coincidência ou não, parece viver num patamar acima das misérias subumanas, seja em razão dos bens deixados por amigos e parentes ou donativos do governo.

Mais tarde, Machado escala o professor-capitalista Rubião e (por que não?), o advogado Bento Santiago, perfeitamente encaixáveis em matéria de desocupação. O tempo para pensar é também índice de distinção social, como remarcou Raymundo Faoro:

"Nem o branco português, nem o branco natural do país podem apanhar a enxada ou tocar no arado. O trabalho braçal degrada e o equipara ao escravo - a esta infâmia é preferível a ociosidade, o parasitismo, o expediente da busca de proteção dos poderosos. O funcionalismo, já enorme em número, absorve essa leva de desprotegidos, com cargos civis e militares. (...) Na

\footnotetext{
${ }^{143}$ Vale a ironia de José Veríssimo: “A vida é boa, mas com a condição de não a tomarmos muito a sério. Tal é a filosofia de Brás Cubas, decididamente homem de muitíssimo espírito.” (História da literatura brasileira, p. 354).

${ }^{144}$ Machado de Assis e a política e outros estudos.

${ }^{145}$ Refiro-me especialmente a Roberto Schwarz, John Gledson e, mais recentemente, Gilberto P. Passos.
} 
base da pirâmide, o escravo negro, sem nenhuma oportunidade de elevação social. O negro, para se qualificar, não lhe bastaria a liberdade, se não a posse de outro escravo. Bem sentiu essa realidade, a um tempo sombria e cômica, Machado de Assis, ao notar que o moleque Prudêncio, negro alforriado, em pleno Valongo, batia furiosamente num escravo seu: nas pancadas nascia o status de senhor.” (p. 254) ${ }^{146}$

Já Brás Cubas é um filho mimado submetido a adornos e caprichos que só a ociosidade permite. A exemplo de outros tantos ilustrados machadianos, como o próprio Bacamarte, forma-se em Coimbra e ingressa na política sem muito poder de persuasão, termina por fazer alguma caridade em tom oficioso e morre vitimado indiretamente pela idéia fixa. A formação coimbrã, como se vê, é tema recorrente em Machado. Não só reproduz um dado verídico, comum entre bem-nascidos e malcriados durante o Segundo Império; alerta para o gosto do diploma com buquê europeizado, aval de papel.

\section{II}

O poderoso Simão Bacamarte instala-se convenientemente numa pequeníssima vila do Rio de Janeiro, sabendo que lá terá ao alcance da mão todos os abusos do reino auxiliado, é claro, pelo evidente desnível entre a sua tão estrita colaboração e os confusos conhecimentos que encontra nos trabalhadores itaguaienses: campo aberto para encontrar um meio termo entre o vício e a virtude dos outros. A descrição do sábio estóico, oferecida por Erasmo de Rotterdam, ajusta-se ao médico provincianocosmopolita:

"surdo à voz dos sentidos, não sente nenhuma paixão; o amor e a piedade não causam qualquer impressão ao seu coração empedernido como diamante; nada lhe foge, jamais se perde, pois têm um olho de lince; pesa todas as coisas com extremada exatidão, não perdoa coisa alguma; acha em si próprio a completa ventura e acredita-se o único rico na terra, o único sábio, o único com liberdade, em suma, pensa que ele apenas é tudo, e o mais interessante é que ele é o único a se julgar desse modo. Amigos? É sua preocupação derradeira, porque não tem nenhum.” (p. 50) ${ }^{147}$

Simão morre em função da busca de uma auto-cura ${ }^{148}$, pois alienista de um homem só, dono de uma faraônica instituição, como a espelhar pela grandeza e imponência seus vazios, ou as faltas em si mesmo - amostra custosa de sua megalomania coimbrã. A percepção de José Carlos Garbuglio é digna de registro:

“(...) em 'O Dicionário’ foi o tanoeiro que se viu guindado à condição de ditador (não esquecer que dicionário e ditador têm a mesma raiz), em O Alienista é um barbeiro que de repente se vê em posto de direção (...) como um caudilho vencedor que tem a cidade e os cidadãos em suas

\footnotetext{
${ }^{146}$ Os donos do poder.

${ }^{147}$ Elogio da loucura.

${ }^{148}$ Para Alfredo Bosi: “A coerência mais pura está no próprio alienista, fiel, do começo ao fim, à miragem da verdade” (O enigma do olhar, p. 91). Nota Paul Dixon, na caracterização das figuras de O Alienista: “Trata-se do médico Simão Bacamarte, por um lado, e todos os demais personagens, pelo outro. Bacamarte é o tipo do homem racional, que não se desvia nunca da eficiência metódica. (...) Assim como a função de Bacamarte é a demonstrar tal consciência racional, a função dos outros é o contrário, pois todos têm desvios lógicos de algum tipo.” (Revista Teresa, 6/7, 2006, p. 194).
} 
mãos. Curiosamente os dois contos são da década de 80, quando os movimentos republicanos se intensificavam e aproximavam do poder com a derrubada da Monarquia, pondo o país nas mesmas condições das republiquetas sul-americanas, entregues à sanha e caprichos de caudilhos sem preparo e sem a menor condição para dirigi-las.” (pp. 475-6) ${ }^{149}$

Quincas Borba, antigo colega dos tempos de colégio de Brás Cubas, só será admitido à residência do amigo quando protegido pelas roupas e botas ${ }^{150}$ que a herança deixada por um parente permitira comprar. É Brás Cubas, um ocioso em busca do elixir para curar os males da humanidade, quem primeiro mal ouve as suas explanações a respeito da teoria de "Humanitas", à hora das fartas refeições. As pseudo-filosofias e teorias, em Machado, acontecem quase sempre em meio a eventos sociais, sejam eles almoços ou bailes.

Rubião é um modesto professor de Barbacena que acaba enlouquecendo por uma confusão de motivos: a herança da loucura especulativa de Quincas Borba e a incapacidade de se adequar ao ritmo de seus espoliadores. O legado financeiro converteo em capitalista deslumbrado, a ponto de julgar possível a aquisição do amor de Sofia, ainda que em prestações habilmente dilatadas pelo amigo deste e comparsa daquela, Palha. Paul Dixon notou que:

“O importante para Machado no romance (e, a meu ver, no projeto literário inteiro) é o contraste das personalidades. A caracterização não é uma questão de traçar realidades psicológicas individuais; não consiste na construção de sujeitos únicos. A prioridade está no exame da relação entre os indivíduos. Machado parece perceber que a verdadeira psicologia do personagem (ou pelo menos de seus personagens) só se revelará na medida em que este participa da interação social. Parece intuir o que o antropólogo urbano, Roberto DaMatta, vai propor um século depois - que a essência da cultura ou da 'personalidade' brasileira está não nos indivíduos, mas sim nas relações entre os mesmos.” (p. 188) ${ }^{151}$

Tal como acontece na novela, o narrador das desventuras de Rubião está na posição de observador. Seu ponto de vista, embora formalmente distanciado, não impede que a leitura de Quincas Borba seja, no conjunto de seus romances, um dramático exercício. Diante desse romance, o leitor não apenas gastava o seu tempo, assim como fazia com os jornais de família; resvalava na indiferença de uns (papel que incluía o narrador e o próprio leitor) sobre outros (Rubião, por excelência). ${ }^{152}$

\footnotetext{
149 “A linguagem política de Machado de Assis” In: Afredo Bosi et al. Machado de Assis.

${ }^{150}$ Conforme Nelson Omegna: “É curioso que a roupa e a casa se unam na composição da mentalidade das gentes. Talvez por isso que casaco e casa, e cabana e capa tenham origens etimológicas nas mesmas raízes.” (Op. Cit., p.143)

151 Op. Cit.

${ }^{152}$ Como observou Maria de Freitas: “O narrador, como artista dos contrastes, focaliza com crueldade o fato de que muitos ascendem na vida social graças às misérias dos outros. (...) cria uma alegoria implacável da indiferença humana e do aproveitamento da situação da miséria alheia. (...) E no seu processo demolidor das falsas atitudes humanas, disfarça os seus fantoches em objetos de consumo, pois
} 
A julgar pelo étimo de seu primeiro nome, Bacamarte - sorte de Napoleão com saberes de grego na província colonial portuguesa - vem, sim, cumprir um voto. Não precisamente com as religiões orientais ${ }^{153}$ ou a ocidental - cujas obras empilha e consulta juntamente com as fichas dos pacientes - mas com a ciência, ou mais especificamente, a louca ciência da razão, una e excludente, que justifica qualquer ato: poder censor desmedido, quase irracional. É que, apesar dos exageros, a única personagem com poder de análise é o próprio médico, alienista exclusivo de si mesmo. Personagem e enredo são atípicos. Lembrando Eugênio Gomes:

"Como expressão humorística a anedota machadiana apresenta comumente duas facetas: a anedota episódica a frisar algum aspecto curioso da personagem ou o sentido da ação, e a anedota estranha à narrativa e nela enxertada para o desenvolvimento de uma idéia ou reflexão filosófica (...) o espírito anedótico colabora às claras na criação de alguns tipos na ficção machadiana.” (p. 18)

A postura dogmática do doutor está bem de acordo com a teoria de apertadas medidas do filósofo Quincas Borba - não por acaso, aclamado por dois desocupados financistas substancialmente egóticos: um rico que nunca trabalhou, Brás Cubas; o outro, um novo rico: Rubião. Na opinião de Antônio Paulo Graça:

"Palha continua adequado ao modelo (...) mas Rubião distancia-se do modelo que lhe foi imposto. Evidentemente ele não é um capitalista típico. Entretanto não o é por ter objetivos maiores, digamos assim, iluministas. Mas por pura mediocridade (...) O horror de Rubião é sua incapacidade de integrar-se a valores, sejam quais forem, os do capitalismo arrivista ou os do iluminismo nobre e autêntico. Rubião é tão somente um elemento levado de roldão pelo natural processo de seleção.” (p. 121)

Em apresentação ao romance Quincas Borba, José Carlos Garbuglio expõe o empecilho que condenara o patético Rubião, numa notável apreciação que condensa o sem-lugar do professor de Barbacena:

"Colocado de chofre no topo da pirâmide, ele ignora os passos que conduzem até lá, facilita o envolvimento e o assalto, densificando o impacto do leitor que se vê cúmplice no projeto sem poder modificar as regras que, em geral, conhece pela própria experiência. (...) Ao herdar as posses de Quincas Borba, herda o cão, uma espécie de consciência que prolonga no presente a lembrança do passado, e também, principalmente, herda os germes da loucura do falecido. Pelo que é e pelo que traz é elemento estranho ao meio a que foi guindado, por isso não pode compreendê-lo mas apenas sofrer-lhe a pressão.” (p. 6) ${ }^{156}$

nos seus relacionamentos há uma verdadeira troca de pessoas e sentimentos ao nível do objeto.” ( $O$ grotesco na criação de Machado de Assis e Gregório de Matos, p. 22).

153 Parece haver paralelos entre Bacamarte e Maomé. De acordo com Félicien Challaye, Maomé “Consegiu fortuna com seu casamento com uma viúva quinze anos mais velha que ele [no conto, Evarista tem quinze a menos que o médico arabista] (...) mais ou menos aos quarenta anos [idade de Simão], foi tomado pelo desejo de reformar, simplificar e vivificar as crenças anteriores”. (As grandes religiões, pp. 241-2).

154 O enigma de Capitu.

${ }^{155}$ A catedral da impureza.

156 “A composição e a decomposição” In: Quincas Borba. 
Gilberto Pinheiro Passos encontra outra explicação para o desajustamento de Rubião, frente à sábia Sofia e o espertalhão Palha:

"Nesse Rio de Janeiro, Rubião, proveniente de Barbacena, sem falar francês, é quase estrangeiro. Não seria ele, portanto, mais exótico do que se imagina? Não podendo se integrar ao Brasil (Barbacena), ou ainda, não conseguindo integrar o Brasil do interior à Corte, nossa elite tenta um encaixe simbólico na França. Daí se poder entender que a posse de um corpo (Sofia) - impossível na vida 'real' - só se torna possível via França, isto é, por intermédio do delírio que estabelece a passagem para outras terras e nossa imbricação no mundo 'civilizado'.” (p. 30) $)^{157}$

\section{O poder dos símbolos}

Na narrativa tudo é sorrateiramente dosado: o vício e a virtude; a cobiça e o desprendimento; a beleza e a feiúra; o discurso e a prática; a religião católica e a árabe (nunca mais Machado tornaria a fazer uso de tantos vocábulos de origem árabe).

Mesmo a dupla empreitada revolucionária fracassa, desnudando as controversas intenções de dois barbeiros que procedem em meio a duas ou mais divergências, embora chegando a objetivos através de protocolos similares.

Porfírio Caetano das Neves ${ }^{158}$ seria uma espécie de sábio de terceiro escalão misto de médico do povo, sangrador e reparador de caras - perdendo em eloqüência e coerência para o Padre Lopes ${ }^{159}$ (outro cordeiro de Simão, arabista) e a suprema conduta lógica de Bacamarte, principal obstáculo para a assunção do sangrador. Nem seu ofício parece a salvo de elucubrações: Porfírio encarna o papel de empunhar a navalha para remendar os arbítrios do médico; mas o faz bem de acordo com o meio-termo, buscando a conciliação, garantia de melhor se amparar no poder político. Para Luiz Costa Lima:

“(...) depois de despertar para a 'ambição do governo', o barbeiro aprende que também a retórica tem limites. (...) O capítulo pretende a colaboração da ciência, mesmo porque o novo governo ainda não tinha 'a confiança dos principais da vila'. (...) De seu lado, Bacamarte não se afasta da paixão classificatória e cogita nos novos casos de loucura que o episódio lhe revelava.” (pp. 29-30) $)^{160}$

\footnotetext{
157 “Quincas Borba e as ambigüidades francesas” In: D. O. Leitura, outubro de 1999.

${ }^{158}$ Com Paul Dixon: "O personagem machadiano, como o brasileiro de DaMatta, vive na negociação das dicotomias.” (Op. Cit, p. 189).

${ }^{159}$ A conduta do Padre, buscando interferir nas posturas de Bacamarte através da esposa Evarista parece ter correspondência em nossos costumes. Segundo Nestor Duarte: “A nossa ordem privada é apanágio do varão, do orgulho masculino, do mando e da hierarquia do marido e do pai. Uma Igreja associada a essa ordem não consegue modificar essa moda ou estilo religioso do varão. Sem ferir o orgulho que o senhoriato infunde, ela se volta por isso com mais frequiência e tato sutil para a mulher e a criança e obtém por ambos, sem tocar na hierarquia da casa-grande, atingir o homem.” (Op. Cit, p. 78)

160 "O palimpsesto de Itaguaí". Para Octávio Ianni: "Aos poucos, o manto monárquico recobriu muitas inquietações e desigualdades, criando a ilusão de que o poder moderador resolvia de forma benigna a maior parte dos problemas criados com o escravismo, as nações indígenas, a questão agrária, as diversidades regionais. Muitas inquietações se apagaram em diferentes lugares, dando oportunidade aos arranjos da conciliação pelo alto.” (A idéia de Brasil moderno, p. 13)
} 
A revolução dos Canjicas não vinga porque pouco fôlego tem, menos coerência guarda e, simbologia não desprezível, é feita não sob o regime da espada, como na Bastilha, mas à base da navalha. Navalha contra o bacamarte: lâmina de pouco alcance versus arma que atira em todas as direções, combinando religiões e demais teorias. ${ }^{161}$

As razões para tal representação, na novela, ligam-se a um dado histórico. Segundo Octávio Ianni: no tempo do Império "Uma solução muito freqüente, no pensamento e na prática, era a combinação de diversas correntes de idéias e distintas práticas, em um singular amálgama de alguma eficácia.” (p. 18) ${ }^{162}$

A barba e o ofício do barbeiro são empregados por Machado em O Alienista e em Quincas Borba. Porfírio não é Tiradentes; mas um tira-barbas que faz relativizar o alcance das insurreições de verdade. Sua existência poderia ser comparada à do barbeiro Luciano, aquele que aproximaria os traços de Rubião ao Imperador Napoleão III, no romance.

O narrador de $O$ Alienista, por sua vez, não se furtou a relatar as oposições entre os espaços de Itaguaí (da Câmara à Casa de Orates, com a barbearia de permeio); tampouco na relação entre a vila e a modernizada corte, cujos parques se fizeram à base do aterro de locais inóspitos: firme contraposição à comarca atrasada da província, que tão de acordo com a série de dicotomias, serve de palco do mundo em miniatura para o maior médico dos reinos de Portugal e Espanha, nichos da fé verdadeira, porque possante, e dos avanços da ciência dogmática.

Itaguaí é pequena, se pensarmos nas dimensões do reino ibérico; mas absolutamente espaçosa para servir de clínica ao ar livre, bem como para abrigar a faraônica Casa Verde. É aplicável aqui o dado ligado à sociedade de corte, estudada por Norbert Elias:

"a magnificência da Casa não era um sinal de riqueza, mas um distintivo de classe. O aspecto exterior da grande casa de pedra é para o grande senhor e para toda a sociedade senhorial o símbolo da posição, da importância, da hierarquia da Casa através dos tempos” (p. 31) ${ }^{163}$

Contrastar tantos dados é aventura quase puramente conceitual. O fim dos extremos é igualmente único: afinal a ciência, importada na biblioteca e no imaginário de Bacamarte, é a única a não admitir questionamentos ou controvérsias. Porta-voz de teorias absolutistas, a ciência é tratada como única área que deve obedecer rigidamente a duas etapas, teórica e prática, tendo como guardião um médico que detém o saber da Ilustração e as práticas reformuladas às pressas pelo Marquês de Pombal.

\footnotetext{
${ }^{161}$ A barba está associada à sapiência desde a Antigüidade, conforme Chevalier \& Gheerbrant e Lurker. 162 Op. Cit.
} 
Autêntico herdeiro de Hipócrates, mensageiro da boa nova, como o arauto Maomé; revolucionário terapeuta ao modo de Pinel $^{164}$ ou Charcot, o mais poderoso brasileiro traz de longe, do velho mundo, o novo saber.

Ardiloso político, lembra certos feitos de Dom Pedro ${ }^{165}$ - líder controverso anunciado com duas décadas de antecedência na assinatura de Porfírio, empolgado com o efeito de seu próprio discurso: original para os itaguaienses, mas repleto de lugarescomuns, perante a história oficial. ${ }^{166}$

No âmbito de sua ciência de tese ou antítese, cada hipótese vale por outra. Daí a impossibilidade de sintetizar na prática os conhecimentos, já que embasados em saberes dicotômicos. Simão oscila precisamente entre o vício e virtude, o que tenta os leitores a ancorá-lo através de recepções maniqueístas - poderoso louco ou “tecnocrata”"167 mal intencionado - representando uma possível perda na interpretação da novela.

Bacamarte é protocolarmente normal ${ }^{168}$ : casado, médico, formado em Coimbra. Mas seu poder, formalizado por dois reinos e saberes, é fato inédito que beira a inverossimilhança e só poderia mesmo ser obliterado pela sede desmedida pela liderança política de dois barbeiros. O sábio bem poderia ser o dono da afirmação de Descartes:

"Inexiste no mundo coisa mais bem distribuída que o bom senso, visto que cada indivíduo acredita ser tão bem provido dele que mesmo os mais difíceis de satisfazer em qualquer outro aspecto não costumam desejar possuí-lo mais do que já possuem. E é importante que todos se enganem a esse respeito; mas isso é antes uma prova de que o poder de julgar de forma correta e discernir entre o verdadeiro e o falso, que é justamente o que é denominado bom senso ou razão, é igual em todos os homens; e, assim sendo, de que a diversidade de nossas opiniões não se

\footnotetext{
${ }^{163}$ A sociedade de corte.

${ }^{164}$ Para Foucault: “é difícil precisar o papel de Pinel. Ele assumiu suas funções a 25 de agosto de 1793 [época em que se haviam recém iniciado as obras do Passeio Público, visitado por D. Evarista e comitiva]. Pode-se supor, como sua reputação de médico já era grande, que ele tinha sido escolhido justamente para 'desmascarar a loucura' (...) Num certo sentido, pode-se dizer que Pinel viu-se investido de um extraordinário poder moral (...) o louco, libertado da animalidade à qual as correntes o obrigavam só se reunia à sociedade através do tipo social” (Op. Cit., pp. 473-4)

${ }^{165}$ Major Neto reparou que: "várias figuras históricas da nobreza luso-brasileira de fins do século XVIII e início do século XIX - D. Maria I, D. João VI, D. Pedro I - poderiam ser aproximadas à figura emblemática de Simão Bacamarte. Cumpre lembrar que D. Maria I, avó paterna de D. Pedro I cognominada de A Louca (...) - foi tratada por um famoso alienista inglês, o 'Dr. Willis' e seus 'evacuantes'.” (Op. Cit, p. 71)

166 Tobias Monteiro, em História do Império, atentou para os comportamentos imaturos de Dom Pedro I, afirmando que o imperador sofria de algum tipo de demência.

${ }^{167}$ A expressão é de Raymundo Faoro (A pirâmide e o trapézio).

168 “Normal” também no sentido de que segue as normas nas quais, a princípio, não interfere. Vale a definição de Ferdinand Tönnies: “a essência da norma pode ser compreendida como uma negação ou uma proibição, ou seja, como uma limitação da liberdade humana (...) [o] homem normal é (...) capaz de se dominar.” (“Normas sociais: características gerais” In: Homem e sociedade, pp. 92 e 96)
} 
origina do fato de serem alguns mais racionais que outros, mas apenas de dirigirmos nossos pensamentos por caminhos diferentes e não considerarmos as mesmas coisas.” (p. 35) ${ }^{169}$

O manifesto de Porfírio aos itaguaienses é um protocolo. Guia-se pela forma, mas a nega ao mesmo tempo, porque composto meramente para oficializar a ocupação do posto de "Protetor da vila" e velar suas intenções de demasiado alcance e pouca lâmina.

Também a escolha da cor verde pode ser significativa: novidade (a primeira casa não verde, mas de janelas verdes, na vila); espaço para experiências em amadurecimento e, coincidentemente ou não, matiz que se equilibra entre o "vermelho infernal e o azul celeste”, nos termos de Chevalier e Gheerbrant (p. 372). Verde ainda “é a cor da expectativa, da esperança, do estar a caminho”, segundo Lurker (p. 747).

Se Bacamarte não teve filhos, gerou a Casa Verde. Obra cuja imponência aproxima criador de seu asilo para loucos: Simão Casa Verde; Simão Bacamarte, agarrado ao asilo até o fim. A morte do médigo; o encerramento da terapêutica.

Sobram a esposa sem sal e infértil, o padre escorregadio, a dupla de barbeiros posicionados estritamente em cima do muro e os vereadores sem posição fixa; o albardeiro endinheirado e os dragões que se aliam aos conjurados contra a revolução científica personificada em Simão Bacamarte.

Há outros níveis de aparente incompatibilidade, no nível da expressão. O discurso mirabolante do barbeiro; a fatuidade da esposa do sábio médico: sem atrativos, contagiada pela pompa trazida a reboque de seus trinta e sete vestidos e os elogios desmesurados de Martim Brito; a soberba de Mateus, albardeiro cujas posses não condizem com as possibilidades usuais de seu ofício. Luiz Costa Lima refaz o percurso de Machado:

"O palimpsesto machadiano responde à conjuntura específica de uma sociedade em que a palavra ‘intelectual' é quase sinônimo de pecado solitário. Por isso é que o exercício intelectual no tempo de Machado consistia - e neste ponto pouco mudamos - em fazer de conta que se pensava, em fingir-se que se admirava a inteligência, quando na verdade, dela se tinha mais medo que do diabo.” (p. 26)

\section{Duelos de palavras vazias}

"Daí a nada o barbeiro, acompanhado de alguns de seus tenentes, entrava na sala da vereança e intimava à câmara a sua queda. A câmara não resistiu, entregou-se e foi dali para a cadeia. Então os amigos do barbeiro propuseram-lhe que assumisse o governo da vila em nome de Sua Majestade(...)

$$
\text { 'Itaguaienses! }
$$

\footnotetext{
169 Discurso do método.

${ }^{170}$ Revista José, 3.
} 
Uma Câmara corrupta e violenta conspirava contra os interesses de sua Majestade e do povo. A opinião pública tinha-a condenado; um punhado de cidadãos, fortemente apoiados pelos bravos dragões de Sua Majestade, acaba de a dissolver ignominiosamente, e por unânime consenso da vila, foi-me confiado o mando supremo, até que Sua Majestade se sirva ordenar o que parecer melhor ao seu real serviço. Itaguaienses! não vos peço senão que me rodeeis de confiança, que me auxilieis em restaurar a paz e a fazenda pública, tão desbaratada pela câmara que ora findou às vossas mãos. Contai com o meu sacrifício, e ficai certos de que a coroa será por nós.

O protetor da vila em nome de Sua Majestade e do povo

Porfírio Caetano das Neves '. ”(p. 274) ${ }^{171}$

Eis um dos episódios mais interessantes da novela de Machado: a leitura da carta pelo barbeiro revolucionário ao tomar de um só gole o poder da vila de Itaguaí. O acontecimento ilustra, bem de acordo com o gosto do escritor, a irrelevância da mera oficialização de feitos: grandes ou pequenos, conforme a perspectiva - fosse do bando de governados, dos pretensos líderes de fachada ou do próprio alienista. Pseudo-alvo que a revolução, por ser de meia-força e meia verdade não derruba, mas corrobora.

Apoiado pela população da vila de Itaguaí, que sofria os desproporcionais caprichos de um cientista revestido de absoluto desinteresse, Porfírio também é favorecido pela indecisa guarda real, com que destitui a vereança: primeiro passo para a derrubada do médico brasileiro cosmopolita, formado no exterior. Simão, sábio grego; Bacamarte, tirano francês: cultura e poder mal encaixados nos dilemas tacanhos da província.

O discurso do barbeiro ${ }^{172}$ é permeado de referências à Majestade. Além disso, é proferido no interior da Câmara $^{173}$, consolidando o simbólico apelo político do local. Não é ocioso lembrar que os revoltosos se servem do mesmo espaço, outrora reservado aos políticos inconsistentes, para protocolar seu novo estatuto perante a comunidade. Novela de contendas ambientadas, não por acaso, em uma vila:

"nas vilas, os ofícios, profissões e encargos eclesiásticos, burocráticos, eletivos ou militares, definindo a variedade de status, oferecendo às diferentes atividades preços dados pelo mercado,

\footnotetext{
${ }^{171}$ O Alienista In: Obra completa. Rio de Janeiro: Nova Aguilar, 1992, Vol. II.

172 O episódio envolvendo a derrubada da Câmara reproduz outro costume de raízes históricas: “o nosso jurismo como o amor a concepções doutrinárias, com que modelamos nossas constituições e procuramos seguir as formas políticas adotadas são bem a demonstração do esforço por constituir com a lei antes dos fatos, uma ordem política e uma vida pública que os costumes, a tradição e os antecedentes históricos não formaram, nem tiveram tempo de sedimentar e cristalizar. (...) as leis e práticas políticas (...) pressupõem e vêm sendo antes a concretização de experiências, tentativas e esperanças por vezes ingenuamente convencidas em face de uma realidade negativa, para construir a estrutura de um Estado.” (Nestor Duarte, Op. Cit., pp. 117-8). Quanto ao papel aglutinador dos espaços, é ilustrativo o registro de Luiz Beltrão: "Nas cartas e relatórios redigidos por um português anti-pernambucano, espião a serviço do governo, delatando feitos e fatos da Revolução de 1817 e descrevendo a situação em Pernambuco no ano seguinte, consta que: "as lojas de fazenda, e as boticas são os lugares onde ordinariamente se falam de todas as novidades, nelas eu compareço a certas horas do dia ou da noite.” (Op. Cit., pp. 38-9)

${ }^{173}$ Segundo Nelson Omegna, “As leis de El-Rei se reverenciavam, mas não se cumpriam, por decisão das Câmaras, quando estas as julgassem desserviço à colônia e ao Estado.” (Op. Cit., p. 98)
} 
emprestando prestígios desiguais aos ocupantes de postos e aos encarregados de serviços os mais distintos, vão elaborando uma complexa estratificação estrutural ou funcional dentro da qual as competições contínuas, a concorrência cotidiana, os conflitos freqüentes franqueiam aos indivíduos, na medida de seus sucessos, o nicho compatível com seu mérito ou com sua ambição.” (pp. 35-6) ${ }^{174}$

Desse modo, suas palavras são falaciosas, mas indispensáveis para que lograsse persuadir a população em que se escorava, para formar um também pseudo-firme caráter político, baseado num pedaço de papel. Para Luiz Costa Lima:

"Na luta entre as retóricas, a sua [a de Porfírio] é a vitoriosa. A multidão se põe em movimento e teria alcançado sua meta caso a técnica de retardamento da narrativa não fizesse aparecer os dragões da ordem” (p. 29) ${ }^{175}$

Os discursos da câmara e o panfleto completam, assim, um quadro de fachada, numa retórica que ilude redondamente aqueles que investiram o líder barbeiro em posição temporária, porque incerto e de motivações incoerentes, se cotejadas com as do próprio alienista. ${ }^{176}$

Em lugar de concretizar o que prometiam suas belas palavras vazias, o barbeiro propõe um pacto com o médico a fim de solidificar seu poderio entre os habitantes. $\mathrm{O}$ analista percebe a trama do líder caprichoso e no momento seguinte à recepção da diligência comandada pelo barbeiro, providencia com que Porfírio e revoltosos sejam encarcerados em sua bastilha: ato que reafirma a imunidade de seu posto, bem acima da Inquisição de Lopes ou do apelo popular irmanado às classes baixas e médias. Aceitando o raciocínio de Luiz Costa Lima:

"Ao assumir o poder, [Porfírio] percebe que necessita de uma legitimação simbólica, que a ciência lhe poderia fornecer. Não por acaso que não emprega a 'teoria da matraca', i. e., não se limita a divulgar quais seriam seus feitos reais ou fantásticos, mas procura prepará-los de fato, por meio de uma discussão cordata e discreta com o depositário de outro poder, Bacamarte. (...) o tema central de 'O Alienista' - que é a loucura? - não pode ser desconstituído sem que se apreenda a articulação tramada entre três variáveis: ciência, linguagem e poder.” (pp. 30-1)

Frente ao protagonista, o antagonista, Porfírio. No segundo plano, gravitam a esposa do médico e o padre Lopes, assim como o boticário Crispim Soares.

Os epítetos favorecem uma tipificação de dois níveis, na narrativa. Enquanto Simão Bacamarte é tratado por cientista, médico e doutor por obra do narrador, os

\footnotetext{
${ }^{174}$ Nelson Omegna, Idem.

175 Op. Cit. J. G. Merquior aponta para a manutenção do torneio lingüístico como algo inerente ao estilo machadiano: "Machado não se limita a ornar de leve o discurso narrativo: visivelmente, ele se compraz em desenvolver os ornatos. Em sua obra, a ausência de ‘declamação' nos diálogos e descrições só tem paralelo na ostensividade retórica da linguagem. Retórica, é claro, no melhor, no verdadeiro sentido, ou seja: de consciência da natureza artificial e técnica da frase literária. Machado, o 'antitropical', tem realmente horror a toda ênfase - menos, porém, à ênfase do estilo.” (Op. Cit., p. 173)

${ }^{176}$ Para DaMatta: “inverter não é liquidar a hierarquia ou a desigualdade, mas apenas submetê-las, como numa experiência controlada - caso das festividades - a uma recombinação passageira” (Op. Cit., p. 177).
} 
demais são imediatamente evocados pela univocidade de sua função. Mas, embora tipificados, às vezes fogem ao "script" e aprontam das suas, invertendo trejeitos de acordo com as necessidades.

Há, de fato, um jogo de Machado com relação às convicções de cada personagem. Ao médico Bacamarte importa-lhe a idéia fixa, aqui travestida de ciência; ao padre Lopes, a religião; ao barbeiro Porfírio Caetano das Neves, o poder político (vereança); ao boticário Crispim Soares, dosar a sua participação nos eventos dúplices em Itaguaí. Por fim, a Evarista ${ }^{177}$, assumir maior autoridade. Caso pseudopatológico: mais futilmente procedeu à medida que aumentou o poderio de seu marido na vila.

A primeira mulher, no sentido que quer a religião, concilia no nome outras posições: a de principal mulher da vila - algo equivalente à primeira dama (sem contar que é a primeira personagem feminina apresentada pelo narrador). Mas é mulher que não parece completa (Adão sem Eva?), já que supostamente incapaz de atender aos apelos do marido, com ganas de prolongar a dinastia dos Bacamarte.

Eva que não é; mulher distinta que não escapa à Bastilha do próprio marido. Ao longo da narrativa, o que a consorte do médico ganha em relevo perde em significado, principalmente quando comparada aos demais alienados.

A relevância do papel de Evarista aumenta principalmente após sua viagem ao Rio de Janeiro - episódio não comentado pela voz do narrador que se combina à primeira reformulação do cientista. Pela primeira vez, Bacamarte titubeia (claro, só no campo teórico; jamais na aparência) e o regresso da comitiva, com a mulher renovada, que estivera na Corte, encaixa-se temporalmente no burilar da segunda teoria do médico: louco é ser normal; ser louco é normal.

Talvez por esse mesmo motivo, sob os olhos sempre bem postos do marido clínico, é que gradativamente Evarista passa de consorte sem sal (“nem bonita, nem feia”) a alienada apimentada - sublime cobaia da mais nova experiência do marido que, diga-se de passagem, não vinha fazendo o papel que ela lhe pedia.

É a teoria científica que absorve Bacamarte. É o mundo abstrato que motiva as atitudes concretas do médico, sem direito à apelação por parte das vítimas de doença, porque não há como advogar em sua defesa. Autoritarismo e arbitrariedade máximos: não há como recorrer de uma condenação sem julgamento ou sentença.

\footnotetext{
${ }^{177}$ Evarista é uma das poucas figuras com aspecto mais convencional, na novela. Mas, a ironia recomeça em seu nome: Eva (do hebraico Hawwâh = vida, a que dá vida; a mãe de todos os vivos; a primeira mulher) + Aristeu (do grego Aristéus = ótimo, que se distingue). Vide M. Lurker (Dicionário de simbologia) e R. Obata (O livro dos nomes).
} 
Não é por acaso que o único júri, embora de peso relativo, fosse constituído a mando do próprio médico, justamente nas últimas linhas da novela, tendo por função votar a própria reclusão do cientista.

Quando o narrador diz ignorar se Simão Bacamarte chegara à verdade, quando internado, aumenta o desejo do leitor de saber o que se passava na mente do médico; reafirma que seu papel, como narrador, termina com a alienação do protagonista.

\section{Da visão de longo alcance}

Quem mais colabora nas questionáveis apertadas medidas arbitradas por Bacamarte é o narrador, que volta e meia combina o testemunho dos cronistas ao sabor das anedotas, criando uma atmosfera que combina o verossímil a seu oposto, contagiando a própria definição do gênero: sorte de novela ${ }^{178}$ que ultrapassa o conto e beira o romance. ${ }^{179}$

Como em $O$ Alienista, o que está em jogo não é exatamente a trajetória do cientista provinciano de mentalidade européia atrasada, o narrador pouco tem a informar sobre o lapso de tempo que atravessa e vive o protagonista.

Casado aos quarenta e tendo dedicado seis anos aos estudos da psiquiatria (teorizar para depois internar), as lacunas temporais não permitem precisar o momento em que Simão abandonou Itaguaí, a vila, enfurnando-se na clínica faraônica - sorte de embaixada bacamartiana.

É que, de fato, há na própria fatura da novela uma mensagem: fugir à convenção ficcional. Se é impreciso o protagonista, se são contraditórias as ações de uns e outros e de uns em relação aos outros, as noções teóricas convencionais (tempo linear, narrador onisciente e relativamente isento, hierarquia das personagens) tudo entra no redemoinho especulativo de Simão Bacamarte, servo de uma pseudociência particular - ainda assim,

\footnotetext{
${ }^{178}$ De acordo com Raymundo Magalhães Junior: "Pelo nome de conto ficaram (...) conhecidos os breves relatos de episódios imaginários geralmente transmitidos ao leitor como fatos conhecidos. Entre o conto e o romance, passou a ser colocada a novela, considerada em termos de duração do tempo de leitura. Tal denominação passou a ser dada tanto a contos excessivamente longos como a romances excepcionalmente breves. Dentro de tal conceituação, podem ser consideradas novelas O Alienista, de Machado de Assis (...)" (Op. Cit., p. 11)

${ }^{179}$ Talvez nem a quantidade de capítulos (XIII) seja casual. O número treze foi apontado como índice de má fortuna desde a Antigüidade: "corresponderia a um recomeço, com a nuança pejorativa de que seria antes um refazer do que um renascer de algo. Representaria, por exemplo, a eterna escalada do rochedo de Sísifo ou o tonel que não se pode encher, das Danaides.” (Chevalier \& Gheerbrant. Dicionário de símbolos, pp. 902-3). Conforme Lurker: "Considerado número de mau agouro entre culturas com sistema duodecimal (divisão do círculo, relógio, antigos sistemas de medida) por seguir-se ao doze perfeito.” (Dicionário de simbologia, p. 731).
} 
acima das picuinhas alocadas no barbeiro ou pelos vereadores, secos pelo poder, e nesse caso, à custa dos colegas de profissão: corrompidos pelo posto que permite legislar.

Bacamarte é colocado pelo narrador num nível superior ao das contendas fortuitas, das fatuidades, porque é um homem sem-lugar. De tanto saber percebe o trágico de se ver apartado, alienado do seio por que trafega com a liberdade máxima, a sua. Ele é uma autoridade, porém autorizado pelo respeito não ao seu saber (questionável), mas pelo título que ostenta e o poder que representa: doutor, braço da autoridade suprema, espécie de delegado do rei na colônia.

Talvez por esse motivo, o capítulo mais significativo seja mesmo o XIII - Plus Ultra, “a vez da terapêutica”, nas palavras do narrador. Aqui têm início e fim as novas e mais revolucionárias soluções de Bacamarte. Para o poeta incurável, Simão inaugura a Academia dos Encobertos, o que não só relativiza a seriedade de todas as “curas”, como estabelece novo vínculo entre a criativa solução do médico à sabida explosão de academias literárias, no país, no século XVIII: imitações em menor nível das arcádias européias. Espelho Brasil, colônia dependente das teorias e sapiências alheias. ${ }^{180}$

O cientista é tão sábio que encontra, enfim, um meio termo: a virtude, mais ou menos interposta entre as faltas e acertos de cada asilado. $\mathrm{O}$ auge do enredo, entretanto, coincide com a impotência do médico.

A narrativa é fruto de depoimentos pseudo-históricos que resvalam para as contendas essencialmente domésticas: obras-de-arte de um anti-narrador ${ }^{181}$ que ora enaltece o caráter e os procedimentos do psiquiatra, ora lança dúvidas sobre sua probidade. Tudo conduz ou deixa-se conduzir pelas meias-tintas, pelo meio termo, pelo talvez.

\footnotetext{
180 "a idéia de Brasil Moderno freqüentemente tem algo de caricatura. Primeiro, caricatura resultante da imitação apressada de outras realidades ou configurações históricas, freqüentemente implicadas em idéias, conceitos, explicações, teorias. Segundo, caricatura tornada ainda mais grotesca porque supõe conceitos e temas a realidades nacionais múltiplas, antigas e recentes, nas quais se mesclam os 'ciclos' e as épocas da história brasileira, como em um insólito caleidoscópio de realidades e imitações.” (Octávio Ianni. A idéia de Brasil moderno, p. 46). Dentre as diversas agremiações culturais sediadas no Brasil colonial, a "primeira delas foi a Academia Brasílica dos Esquecidos, fundada na Bahia pelo vice-rei Vasco Fernandes César de Meneses, em 1724, cuja inspiração decorreu da solicitação de D. João V. (...) Apesar de a produção dessas academias estar quase sempre impregnada pelo espírito áulico e pela retórica excessiva, elas constituíram o primeiro esboço de uma esfera pública intelectual na colônia” (Dicionário do Brasil Colonial, pp. 14-5)

${ }^{181}$ Não se pode esquecer que Machado cultivou a atuação de seus narradores nos jornais, antes mesmo de dar início a sua obra ficcional propriamente dita. Como atesta Lúcia Granja: "uma vez que nos deparamos com a sua produção jornalística, uma questão de fundamental importância é o reconhecimento do grande prosador que Machado se nos apresenta ali, já desde os tempos da juventude. (...) em Machado, a citação dos textos literários, os recursos narrativos de que se utiliza para recontar a semana e, dentro disso, os outros recursos que cabem 'a construção de ironias, humor, ao enquadramento do tempo presente em uma comédia divertida cujo espectador é o leitor, guiado pelas mãos hábeis do narrador da crônica, tudo isso
} 
E, num jogo que elege o cômico para tratar de temas de inegável importância, torna-se complexo afirmar os limites entre a verossimilhança e a inverossimilhança. Certos contos e romances de Machado, de acordo com Hélio Seixas Guimarães, “também podem ser lidos como dramatização da relação do escritor com seu público.”"182

Se Bacamarte traduz-se em Sim ou Não, como sugere o nome, os itaguaienses obedecem ao seu movimento de Sim $e$ Não, agindo rigidamente em dois tempos, em razão mesma da variável expectativa de alçar maior poder próprio ou fugir à escolha de cada nova teoria, poderosa em suas inatingíveis maneiras simiescas.

Bacamarte não se encaixa no tipo acabado de Palha, tampouco se emparelha à ingenuidade de Rubião. Personagem que foge à regra machadiana de compor figuras de extremo arroubo ou discrição, o médico-monstro-sábio-símio obedece estritamente aos desígnios da ciência cega e auto-esclarecida; nega os favores do rei, engana o padre e corresponde aos interesses de seu amigo ourives. Do geral ao particular.

É justamente por seguir tão fielmente os dogmas pseudocientíficos em que crê excessivamente, que manda compor uma assembléia particular com o único fim de confirmar as próprias deliberações sobre seu confinamento na Casa Verde.

A casa-hospício de Simão Bacamarte - verde: casa da esperança (de quem?) na cura dos alienados - comporta uma "vasta sala, onde fulgurava a mais rica biblioteca dos domínios ultramarinos de Sua Majestade” (p. 286) e uma nada modesta sala de visitas: "cerca de cinqüenta convivas sentavam-se em volta da mesa de Simão Bacamarte”.

As dimensões internas da casa revelam uma proporção entre os amplos espaços de leitura e estudos (aspecto particular/profissional) e o de visitas (dado social), o que implica dizer que a mania do médico de tudo equilibrar, reflete-se na própria arquitetura.

Sabe-se que visão mais panorâmica das coisas pode ser conquistada de acordo com a altura em que os olhos estão colocados. A “Casa de Orates” não só é a segunda maior de Itaguaí. O fato de perder em tamanho somente para a casa de um albardeiro, revela em si o sintoma da suposta demência de Mateus: aponta o senso comum, cujo rigor está sob a mira, do ponto de vista do cientista.

transporta para bem perto do leitor a experiência literária em versão íntima e cotidiana.” (Machado de Assis, escritor em formação (à roda dos jornais), p. 22).

${ }^{182}$ Hélio Guimarães afirma ainda que: "Essa procura de um status para a figura do leitor constitui um dos esportes favoritos do narrador machadiano, que se dedica a ele com assiduidade e afinco não só na crônica, mas também na crítica, no conto e no romance.” (Op. Cit., p. 26. Citação anterior: p. 29). 
A Casa Verde é alta - com direito à varanda (duas, na falta de uma) ${ }^{183}$ - posto onde o médico se posiciona para disputar verbalmente com Porfírio certas arbitrariedades: discursos necessariamente dúplices, para dizer quase a mesma coisa: um à base da retórica da fria exatidão científica; outro, embasado na retórica passional dos injustiçados.

“- Abaixo a Casa Verde! bradavam os Canjicas.

O alienista caminhou para a varanda da frente, e chegou ali no momento em que a rebelião também chegava e parava, defronte, com as suas trezentas cabeças rutilantes de civismo e sombrias de desespero.” (p. 272)

Em outras palavras, ambos os discursos tratam a matéria psiquiátrica com ares de poder político, de forma imprecisa: assiste-se à medicina de psiquiatra versus de barbeiro - este, preciso como Bacamarte, mas longe da cabeça, mais próximo da emoção e mais estritamente na carne, experiente sangrador.

A altura da Casa Verde aproxima-a de uma espécie de castelo, conhecido símbolo da autoridade concentrada em duas mãos (historicamente, a mão dos reis). $\mathrm{O}$ cabeça de fato é instalado no espaço de maior altura e amplitude. Está bem protegido, portanto, além de se tratar do homem culturalmente mais bem guarnecido da vila.

Tendo a visão de cima (fisicamente) e apoiando seu olhar investigador no conhecimento superior e prévio (sintoma da pré-potência, aliás), não é de se estranhar a miopia doutoral do médico.

Seu conhecimento longínquo entra em simetria com sua miopia provinciana: é formado em Pádua e Coimbra - esta, cidade do Reino de verdade que o médico se recusa a administrar por saber-se dominador de outro reino de que trata a ficção: a província.

Razão e visão ganham maior relevo, dado o apelo simbólico de a Casa Verde ter sido construída em sete dias, sob as ordens do demiurgo reinol, na vila. O porém está no fato de que a mesma suposta visão de longo alcance, favorecida pela posição física e política em que está alçado o médico, não permite enxergar - ao menos, a princípio - os detalhes implicados nas manias de uns, de outros e as suas próprias.

De fato, é só quando “descura” os supostos virtuosos que Simão Bacamarte, sem pacientes a tratar, tendo abandonado o aparato técnico-cientificista, para se reaproximar dos amigos (ou seja, ao rés do chão da província) dá-se conta da proximidade que mantivera o tempo inteiro em relação aos seus pacientes, aqui em duplo sentido.

\footnotetext{
${ }^{183}$ Para Roberto DaMatta: “A própria divisão espacial da casa brasileira já sugere a possibilidade da gradação (e do compromisso, e da mediação), já que a varanda é um espaço ambíguo, entre a casa e a rua
} 
Bacamarte percebe que a visão do alto, por ser panorâmica, enfocara o alvo errado. Não é a loucura o mal que assola Itaguaí; são os homens. E como não se pode “delimitar os limites entre razão e insânia” - o que seria um procedimento teoricamente racional, e por isso humano - não se pode chegar, com a visão de cima, ao comezinho, ao solo em que estão plantados os vícios, as virtudes dos homens, não exclusivamente os leigos. José Guilherme Merquior salientou que:

“ ' $O$ alienista', obra-prima da ironia machadiana, fere magistralmente um dos leitmotive da sua fase madura: o tema da irracionalidade, da imoralidade do universo humano. No velho prisma clássico do desconcerto do mundo, Machado vê principalmente o triunfo da insensatez sobre a razão, a revelação da arbitrariedade das normas sociais e, com esta, da escassez e fragilidade da virtude. Bacamarte é grotescamente vencido pela realidade, porque, perseguindo a loucura, identificou-a com a constelação dos vícios humanos: do ponto de vista moral, a humanidade é incurável. Verdade e moralidade são simples produtos da opinião, movida pelos apetites e interesses.” (p. 164) ${ }^{184}$

Além do caráter arbitrário do médico e de alguns habitantes - conforme a perspectiva de cada um sobre os componentes da fórmula - é de se notar que a assembléia que reúne antes de sua própria reclusão necessariamente fugiria ao escopo. Constituída de notáveis em justa medida - todos já curados ou descurados - amigos e inimigos simbolizam facções equilibradas na figura do padre com nome de lobo: figura de personalidade estável, por isso, o maior rival da ciência reta de Simão.

Ao lobo restam as sobras do poder do médico e, autorizado pelos protocolos do saber eclesiástico, acrescenta ao auto-julgamento do sábio perante a platéia-assembléia um não providencial: providencial em duplo sentido.

De acordo com o líder espiritual - reinvestido na posição usual frente ao grupo convocado pelo cientista - além de isento de defeitos, Bacamarte teria o “dom da modéstia”: veredicto igualmente questionável que consolida o caráter ambíguo dos presentes e derruba a magnificente razão, ironicamente em novo acordo com os critérios estatísticos do médico.

É também por esse motivo que o narrador afirma não ter conhecimento se Bacamarte chegara à cura de si mesmo: afinal como curar o que já se supunha remediado, ainda que por critérios duas ou três vezes contrários? Lembrando algo da súbita lucidez de Dom Quixote, à beira da morte, se o cientista portou-se como louco durante toda a sua estadia na vila de Itaguaí, o reconhecimento da necessidade de sua

(ficando, em geral, de frente para a rua), ao passo que a sala de visitas é também um espaço intermediário, mas dentro da casa.” (Op. Cit., p. 92)

184 "Machado de Assis e a prosa impressionista” In: De Anchieta a Euclides: breve história da literatura brasileira - I. 
própria internação pode completar a auto-análise feita por Brás Cubas, aproveitada a interpretação de Alfredo Bosi:

"O fluxo de consciência de Brás mostra o direito e o avesso da coisificação social, fazendo-o ouvir, em meio a vozes famliares e cúmplices, as censuras do leitor sensível, como ouvirá o narrador de 'O espelho' os cochichos do nada. Por esse movimento de sentido a resposta do sujeito ao mundo e a si mesmo diz ora sim, ora não, oscilando na dúvida e desarmando com aparente isenção o cotidiano moral fluminense que é o contexto de sua aparência.” (p. 45) ${ }^{185}$

Tudo que se relaciona à virtual razão escora-se em viciadas virtudes (aqui em sentido aristotélico, para reforçar também a origem grega do nome do médico). Daí a aparente primeira conclusão de que ser normal é ser medíocre. O único homem de extremos é Bacamarte, por isso mesmo, trancafiado como louco pelas próprias mãos de relativas medidas: desmedidas. Como afirma Bosi:

“afora esses casos já apontados ao ridículo pelo bom senso das gentes, o que haveria de anormal na atitude dos outros recolhidos à Casa Verde? Apenas um extravasamento qualquer da subjetividade, uma afirmação mais forte de caráter, um gesto do eu que se aparta da média, cuja conduta Bacamarte supõe conhecida e regulada pela rotina, sem um traço sequer de diferenciação. (...) O 'institucional' sem surpresas, esta é a essência da razão que se impõe como critério de sanidade na cabeça do alienista.” (p. 91)

Suas providências radicais são justificadas pela devoção algo religiosa à ciência, matéria única e superior que faz recuar inclusive os políticos diante do compromisso de representação popular. Conhecimento inatingível que leva o barbeiro a temer algum trunfo extra do alienista, ainda que o psiquiatra fosse aprisionado sob o regime da navalha.

Navalha como guilhotina reduzida: metonímia que aproxima ironicamente as dimensões da pseudo-revolução do barbeiro, no âmbito da ficção, à polêmica ascensão burguesa na França, evento histórico. O movimento de província é mal aclimatado, mas não evita pensarmos nas divergências que se combinaram originalmente no entorno da Bastilha, espelho maior da Casa Verde.

Se falarmos em ideologias, na novela, poderemos apor três territórios nítidos: o novo, mas conduzido de forma autoritária, representado por Simão Bacamarte; o antigo e conservador, apregoado pelo padre Lopes, em cima do muro do princípio ao fim da dinastia Bacamarte, em solo terreno; e o revolucionário, liderado pelo barbeiro Porfírio, devidamente corrompido pelo poder.

Curiosamente, o que os motiva é o recurso ao abstrato como expediente para defender, numa retórica vazia, as atitudes mais que concretas: a suposta isenção da ciência; os inabaláveis votos da fé; a contestação inerente à revolta de fachada. E o que

${ }^{185}$ Brás Cubas em três versões. 
são o conhecimento, a crença e a ambição, se não algumas das marcas universais inerentes ao homem? Itaguaí: universo não só de Bacamarte.

Em $O$ Alienista quase todos andam em caminhos tripartites. A um só tempo temos três pontas: as três teorias de Simão Bacamarte; as três posturas de Evarista (submissa, fátua e alienada); Crispim Soares (escudeiro, adversário, alienado) e de Porfírio (barbeiro, líder da revolução, alienado).

E se há três matrizes, na novela (ciência, religião e política), há que se pensar por extensão em outras, por exemplo, num transplante do ideário positivista - ainda mais nítido no romance Memórias póstumas de Brás Cubas. Tradição, propriedade e família; ou, na concepção original: pátria, família e religião: Porfírio (patriota bem brasileiro); Bacamarte (pai sem filhos) e Lopes (padre lobo).

Ninguém resiste a três instâncias, na novela. Perpassando todos os níveis sócioeconômicos e ideologias está a assustadora normalidade; ser normal é portar mediocridade: tema que possibilita o diálogo de Machado com seu controverso "sucessor”, Lima Barreto - que supostamente não teria conseguido dar aos itens polêmicos o trato de uma posição esteticamente mais resguardada, frente ao desejo de panfletar. Lúcia Miguel Pereira notou que:

“Ambos usaram do romance como da expressão mais espontânea e legítima para traduzir a sua posição em face da vida, o que equivale a dizer que o violento Barreto e o dubitativo Machado precisaram igualmente desse recurso para se realizarem. Criadores autênticos, se não pudessem escrever ficariam como mutilados, privados no seu meio de comunicação. Para eles - e foram neste ponto, como em outros, únicos cada um em seu tempo - a literatura foi mais uma servidão do que um dom, uma fatalidade do temperamento mais do que uma graça do espírito. (...) Mas ao passo que a vida de Machado de Assis descreveu uma harmoniosa curva ascendente, a de Lima Barreto se desenvolveu em ritmo catastrófico.” (pp. 276-7) ${ }^{187}$

Com ela concordou H. Pereira da Silva, nos anos 70:

“a solidariedade de Lima Barreto pelos negros e mulatos tem raízes psicológicas mais profundas que a propalada indiferença do outro mulato bem sucedido entre os brancos: Machado de Assis. Ambos, cada qual a seu modo - um omitindo, o outro, expondo - foram vítimas do mesmo estigma racial, obstinadamente negado ao povo brasileiro, tão racista quanto a inconsciência deliberada por tal problema o faz crer o inverso.” (pp. 54-5)

Sérgio Buarque de Holanda também ressaltou, de outro ponto de vista, as diferenças entre um e outro:

"Machado de Assis aristocratizou-se por esforço próprio e da disciplina que para isso se impôs, ficou em seu temperamento e em sua obra uma vertente inumana, que deveria desagradar a espíritos menos capazes de contensão. Desagradaria como se sabe, a José do Patrocínio e desagradou a Lima Barreto. Deste pode-se dizer que não conseguiu forças para vencer, ou

\footnotetext{
${ }^{186}$ Machado de Assis: o enigma do olhar.

${ }^{187}$ Prosa de ficção.

${ }^{188}$ Lima Barreto - escritor maldito.
} 
sutilezas para esconder, à maneira de Machado, o estigma que o humilhava. (...) a mágoa da frustração, longe de esconder-se sob uma aparência de placidez, ou aguçar-se na malícia de uma sutil, agridoce, ironia, encrespa-se, ao contrário, e exaspera-se e fere quando reduzida à palavra escrita. Para ele a literatura constituiu, quase uma forma de vingança.” (pp. 135 e 142) ${ }^{189}$

Discretamente posicionado em relação às idéias e fatos, por vezes Machado foi apenas parcialmente compreendido, inclusive pelo próprio Lima, conterrâneo cujo reconhecimento - diferentemente do que sucedeu ao primeiro - só veio tardiamente, quando os seus romances já haviam perdido a tônica do contexto original, convertendose com relativa facilidade e a justiça devida, em textos suscetíveis de leituras artísticas, ainda que anacrônicas e, por vezes, ingênuas.

189 “Em torno de Lima Barreto” In: Cobra de vidro. 
PARTE III - IMPOTÊNCIA 


\section{Lima Barreto: lúcidos e marionetes}

“a maior força do mundo é a doçura” (Gonzaga de Sá)

Possivelmente, as críticas mais densas e equilibradas sobre a obra de Lima Barreto situam-se num intervalo aproximado de quatro décadas - dos anos 1950 aos 90 - o que significa que o escritor levou pelo menos trinta anos para ser mais justamente avaliado, e de um ponto de vista não exclusivamente estético.

José Veríssimo talvez tenha sido o primeiro historiador literário a mencionar o nome do escritor, em $1907^{190}$, em razão do aparecimento da revista Floreal e do então recém publicado romance Recordações do escrivão Isaías Caminha. Mais tarde, o mesmo Veríssimo teceria severas críticas ao autor, apegado principalmente à suposta negligência do escritor quando da revisão de seus romances.

Um dos críticos partidários de Lima Barreto - raros, naquela altura - foi o entusiasta Tristão de Ataíde. Em 1919, ano de lançamento do romance, afirmava que a personagem Gonzaga de Sá seria:

“(...) um velho irmão do Conselheiro Aires, que encara o mundo sem preconceitos, com um amor entranhado pelos humildes e sofredores, e uma íntima queda pelo paradoxo engenhoso.” (p. 15) $)^{191}$

Uma das características da obra barretiana, vista de uma perspectiva algo panorâmica, é que ao escritor pareciam interessar tanto ou mais os temas que a fatura literária propriamente dita - fato que o aproximava, como crítico literário e político, de Manuel Antônio de Almeida, com as necessárias ressalvas de conteúdo e método de composição.

\footnotetext{
${ }^{190} \mathrm{O}$ artigo de José Veríssimo, de cujo título não disponho, foi publicado no Jornal do Comércio, em 9 de dezembro de 1907, segundo a informação de Astrojildo Pereira registrada em Crítica impura, conforme nota da página 36, daquele.

191 “Um discípulo de Machado”. Rio de Janeiro: O Jornal, 18/6/1919. A aproximação proposta por Tristão de Ataíde não é totalmente aceitável, porque Aires, o Conselheiro machadiano, não é tão isento como Gonzaga de Sá, como pretendia o referido crítico. Vida e morte de M. J. Gonzaga de Sá pode ser definido como uma fusão do "romance de personagem" ao "romance de drama", respeitando a "divisão proposta por Edwin Muir (The structure of the novel, 1929): 1) romance de ação, quando a intriga ressalta mais do que os demais componentes da obra, como de hábito na ficção romântica; 2) romance de personagem, quando a ênfase é posta nos protagonistas e, por seu intermédio, na comunidade social, como, por exemplo, o romance realista e o naturalista; 3) romance de drama, quando a personagem e a ação se fundem num corpo só, de tal forma 'que temos dificuldade em achar termos para descrevê-la sem dar a aparência de exagerar’.” (Massaud Moisés, Dicionário de termos literários, p. 456). Para Wolfang Kayser "Há três elementos que criam o mundo e por isso representam os elementos estruturais das formas épicas: personagem, espaço e acontecimento.” (Op. Cit., p. 248). Aplica-se à narrativa barretiana o que Márcia Lúcia Guidin reparou sobre o estilo do narrador Aires, em acordo com a idade do conselheiro: "Machado de Assis propunha um 'estilo da velhice' (...) o tom do diário vem dum poderoso freio desses excessos estilísticos.” (Armário de vidro, p. 78)
} 
Dentre os temas que obsedavam o escritor, estava a falta de solidariedade entre os homens de seu tempo. Tal aspecto negativo - segundo Lima, também reflexo de uma mentalidade atrasada que aceitava sem ponderação os costumes e leis dos países em estágio sócio-econômico e cultural mais avançado - nortearia, implícita ou explicitamente, as complexas relações de interesse entre suas personagens. Algo que sobrepujava, muitas vezes, o dado eminentemente estético. Antonio Arnoni Prado, um de seus principais estudiosos, é preciso:

[De seus] "romances, Vida e Morte de M. J. Gonzaga de Sá é talvez o que melhor se enquadre naquela vertente que um autor como Mário de Andrade chamou um dia 'romances de desistência', ou seja: romances claramente marcados pela recusa da ação, pela distância crítica amadurecida nos bastidores da elocução, mais que pelo pitoresco da matéria narrada e pela animação épica” (p. 3) ${ }^{192}$

Entretanto, o tópico (falta de solidariedade) apareceria ainda mais explicitamente nas crônicas e, principalmente, em sua irregular colaboração em jornais de pequeno e médio porte, sediados não exclusivamente no Rio de Janeiro - principalmente no que se refere à produção concentrada entre 1918 e 1922. Astrojildo Pereira observaria, no início da década de 1960, que:

[Lima Barreto] "Sem ser um panfletário profissional, imprimia a muitos dos seus artigos a feição de áspera crítica política e social, e fazia da sátira de costumes uma arma permanente de combate. São as mesmas características que se encontram na sua obra de ficção e que nos seus artigos aparecem, naturalmente, de modo mais direto e desnudo. E eu acredito que não se pode aprofundar o conhecimento e a compreensão da sua obra de ficção sem se conhecer e compreender as reflexões e memórias que nos deixou sob a forma de artigos e crônicas de jornal.” (pp. 37-8) $)^{193}$

Em 1976, Antonio Candido seguiu o mesmo raciocínio, considerando que:

“(...) nos escritos pessoais e nos artigos a sua concepção de literatura se realiza às vezes melhor, porque é mais adequada a eles. O seu ideal declarado é a representação direta da realidade; e no fundo os recursos expressivos lhe parecem intermediários incômodos. Tanto assim que, quando comenta um romance de outro autor, ele o trata como se fosse documento, não ficção, e o condena ou louva exclusivamente por este lado, mostrando desinteresse pelos aspectos formais, sobretudo os inovadores.” (p. 41) $)^{194}$

No mesmo ensaio, o crítico menciona o recorrente emprego por parte de Lima Barreto dos "olhos”, que funcionariam "em mais de um sentido como apoio simbólico da narrativa”195. Tal aproximação é similar à interpretação dada por Cavalcanti Proença, por ocasião do lançamento da obra completa de Lima Barreto, em 1956. Para este, “o

\footnotetext{
192 “Ilusões da modernidade em tom irreverente” In: Lima Barreto. Vida e morte de M. J. Gonzaga de Sá.

193 “Posições políticas de Lima Barreto” In: . Crítica Impura.

194 “Os olhos, a barca e o espelho” In: A educação pela noite \& outros ensaios.

195 Idem, p. 43.
} 
olhar” correspondia, como descrição dos aspectos exteriores, à índole de determinadas personagens.

“(...) os olhos são o traço físico, por assim dizer, obsedante. Em Machado de Assis eram os braços femininos, a que chegou a dedicar um soneto; outros escritores fixaram neste ou naquele detalhe da figura humana a síntese de uma personalidade; Lima Barreto fará dos olhos o centro de interesse de seus personagens” (p. 24) ${ }^{196}$

Detalhes mais estritos, verificáveis nos conteúdos de seus escritos, podem ser um contraponto às severas anotações de alguns críticos. Muitos estiveram mais preocupados com a forma, incluídos aí os cuidados com a linguagem e a correção gramatical, o que os levava a esquecer o alvo (a obra) e, muitas vezes, a pertinência dos temas ou mesmo a habilidade do escritor.

Por muito tempo, foi uma tentação para a crítica literária priorizar, em suas análises, o fato de Lima ser também dono de certo azedume - o que acabou se confirmando numa das marcas de sua personalidade, já estereotipada, mesmo porque $o$ homem Lima tinha perdido lugar para o esteta.

De qualquer forma, ainda assim um azedume que vinha supostamente associado à forma e matéria de suas narrativas, quando não transposto para a ficção sob a forma de registro. Registro útil, pois ilustrava e permitia questionar as conveniências em sociedade, a aparência, a leviandade das coisas.

Um dos poucos estudiosos que logrou conciliar um cuidadoso e extenso levantamento das qualidades da obra, sem enfatizar as supostas deficiências na composição de Lima Barreto, foi Francisco de Assis Barbosa. Sua biografia, aliás, talvez tenha inaugurado uma crítica menos afeita ao rigoroso exame de cunho formal.

Barbosa também demonstrou habilidade ao sensibilizar os leitores diante dos percalços que o escritor atravessou: as dificuldades enfrentadas com as questões familiares (agravadas com a internação de seu pai); o fracasso no ensino superior; o inconformismo como homem de posto burocrático; o insucesso nas letras; o reduzido círculo de amizades e demais relações afetivas que fossem duradouras.

Acrescentem-se os problemas com o alcoolismo e a falta de recursos financeiros, aliados à discreta recepção e comercialização de seus romances (Vida e morte de M. J. Gonzaga de Sá, aliás, foi o único romance feito sob encomenda e em função das benesses do amigo Monteiro Lobato, então proprietário da Editora Brasiliense).

\footnotetext{
196 “Prefácio” In: Lima Barreto. Impressões de leitura.
} 
Para a crítica, constituía verdadeiro chamariz estudar a obra pelo homem Lima Barreto e vice-versa, porque costumava acontecer certa indistinção entre os objetivos da literatura que ele pretendia e os seus próprios. Como salientou Antonio Candido:

"Para Lima Barreto a literatura devia ter alguns requisitos indispensáveis. Antes de mais nada, ser sincera, isto é, transmitir diretamente o sentimento e as idéias do escritor, da maneira mais clara e simples possível. Devia também dar destaque aos problemas humanos em geral e aos sociais em particular, focalizando os que são fermento de drama, desajustamento, incompreensão. Isto, por que no seu modo de entender ela tem a missão de contribuir para libertar o homem e melhorar a sua convivência.” (p. 39) ${ }^{197}$

Do ponto de vista mais estritamente estético, talvez o que de melhor se tenha escrito sobre Lima Barreto encontre-se reunido no ensaio do também romancista Osman Lins $^{198}$, publicado na década de 1970.

As principais contribuições de seu estudo tratam do "ilhamento" e "da inoperância dos atos de cada personagem sobre o próximo e sobre o meio"199. O isolamento das figuras se combina a uma espécie de "crise" do narrador. Ao "insulamento" das personagens barretianas soma-se a impossibilidade de se comunicarem $^{200}$, o que revela algo do mundo à margem em que viveu o próprio Lima Barreto. Nas palavras de Osman Lins:

"Lima Barreto inaugura na ficção brasileira, sem dar-se conta disso, segundo tudo indica, o tema da incomunicabilidade, tão caro à arte contemporânea, surgindo como um antecipador, um anunciador do nosso tempo e das nossas criações.” (pp. 34-5) $)^{201}$

No plano narrativo, percebe com notável acuidade que os conflitos não se efetivam, já que são sistematicamente abrandados:

"temos por vezes a impressão, com os hábitos formados em outras leituras e no teatro, de que algo se prepara contra a personagem e que esta dentro em breve será arrebata numa intriga. Ameaças, no entanto, que logo se desfazem. (...) Há sempre qualquer coisa de solitário nos dramas; jamais se adensam e explodem” (pp. 51 e 54$)^{202}$

\footnotetext{
197 Op. Cit.

${ }^{198}$ Lima Barreto e o espaço romanesco.

199 Op. Cit, p. 37.
}

${ }^{200}$ A seguinte observação de Bakhtin, a respeito de Dostoievski, parece aplicável a Lima Barreto: "Em Dostoievski, todas as qualidades objetivas estáveis da personagem, a sua posição social, a tipicidade sociológica e a caracteriológica, o habitus, o perfil espiritual e inclusive a sua aparência externa, ou seja, tudo de que se serve o autor para criar uma imagem rígida e estável da personagem - o 'quem é ele', tornam-se objeto de reflexão da própria personagem e objeto de sua autoconsciência; a própria função desta autoconsciência é o que constitui o objeto da visão e representação do autor.” (Problemas na poética de Dostoievski, p. 40). Segundo Bakhtin: "A consciência do autor é a consciência da consciência, isto é, a consciência que abrange a consciência e o mundo da personagem” (Estética da criação verbal, p. 11)

201 Op. Cit.

202 Idem. Lembrando Chklovski: "Se não há solução, não temos a impressão de nos encontrar diante de uma trama” (“Construção da novela e do romance” In: Toledo, Dionísio de Oliveira (org.) Teoria da literatura - formalistas russos, p. 208) 
Em 1954, Alceu de Amoroso Lima fizera constar de nova edição de Vida e morte de M. J. Gonzaga de Sá a informação de que, embora iniciado em 1906, com um de seus capítulos publicado na imprensa, em 1910, o romance foi mantido em poder do próprio Lima Barreto, que o revisou várias vezes, antes de enviar os originais, na forma que conhecemos, a Monteiro Lobato, em 1919.

A razão para tal resguardo teria afirmado o próprio Lima, que considerava desde o começo, como seu romance mais bem acabado, o mais “cerebrino” - o que não causaria o costumeiro impacto entre os leitores ${ }^{203}$, devido ao enredo de tom menos trágico e à linguagem mais moderada que aquela observada nos demais.

\section{Vida e morte: o panfleto em fogo brando}

As coisas diferem dos homens. Em primeira instância, estes atingem os outros com ou através das primeiras - que podem ser valores louváveis ou interesses tacanhos. Essa é, muito resumidamente, a filosofia do narrador Augusto Machado. Moço de vinte anos, de certa forma, recriado intelectualmente pelo resignado Gonzaga de Sá, este quase um Montaigne carioca: “Não se corre nem para a morte a quem amo” (p. 23) 204

O estóico Gonzaga de Sá comporta-se de forma que combina a sede de um jornalista (Isaías Caminha) à descrença do famoso major desiludido do romance publicado anteriormente (Policarpo Quaresma). Não tem a frustração precoce do primeiro e já perdeu o elemento visionário do segundo. É um experiente servidor público - ofício que não o afasta de ser uma espécie de Sócrates, recriado em território fluminense.

Um andarilho que nada espera, em ninguém deposita confiança e pouco sentimento extravasa - como se percebe nas conversas com seu confidente e narrador que faz as vezes de um Platão de empréstimo.

A mais machadiana das figuras de Lima Barreto ${ }^{205}$ lega ao amigo Augusto Machado uma série de reflexões bem postas sobre o poder da imprensa, o preço dos êxitos e a implacável mediocridade. Esta, um requisito cuja trilha poderia ser

\footnotetext{
${ }^{203}$ Segundo Alceu de Amoroso Lima: “(...) como o romancista desejava aparecer com 'escândalo’, optara pelo livro que ele próprio julgava desigual, propositalmente mal feito, brutal por vezes, mas sincero sempre', ou seja, o Isaías Caminha, deixando na gaveta o 'cerebrino' Gonzaga de Sá, por ser 'muito calmo e solene, pouco acessível, portanto’ (p. 19). “Nota prévia” (1954)

${ }^{204}$ Vida e morte de M. J. Gonzaga de Sá, 1997.

${ }^{205}$ Depoimento do próprio Lima Barreto, registrado em O Cemitério dos Vivos: "As minhas leituras literárias eram poucas. Em menino, lia os autores nacionais: Alencar, Macedo, Manuel Antônio de Almeida, Aluísio, Machado de Assis; e também os poetas (...) Depois de dezesseis anos, pouco procurei literatura, a não ser o Paulo e Virgínia, o D. Quixote, o Robinson” (p. 132).
} 
palmilhada tanto no interior da repartição pública quanto nos espaços abertos em que acontecem os eventos, inclusive, comemorativos (como a celebração da República) tão enfatizados por Manuel Antônio de Almeida - e seus respectivos rituais, adorados pela sociedade de homens que necessitavam lustrar o seu verniz.

Apatia e impotência são os substantivos que estabelecem a principal característica comum a Augusto e Gonzaga. O próprio Augusto observa a analogia de sua pessoa com a natureza: “o sol causticante do seu verão ensinou-me a sofrer com resignação e a me curvar aos ditames das coisas, sempre boas, e dos homens, às vezes maus” (p. 22)

Mas não se pode esquecer o papel de outras personagens, principalmente o de Escolástica, tia de Gonzaga de Sá. Assim como a Luizinha de Manuel Antônio de Almeida representa o caminho de acesso à ordem aparente (emprego, mulher e filhos) para Leonardo-filho, agora fardado sob os favores do major Vidigal; assim como Evarista é o contrapeso fútil à intelectualidade do machadiano Bacamarte - Adão sem filhos - na ficção de Lima Barreto, as mulheres foram empregadas também como item de realce ou opacidade das figuras masculinas. ${ }^{206}$

Particularmente em Vida e morte de M. J. Gonzaga de Sá, as personagens femininas são relegadas ao plano de categoria social emergente. D. Escolástica, a plácida tia de Gonzaga, e Alcmena, motivo do fuxico de Augusto, quando no velório, contrastam com as figuras masculinas.

Fátuas ou rudes, as mulheres teriam o papel de "nos polir" - séria ironia de Gonzaga de Sá - por meio da imitação dos modismos estrangeiros. É que o velho metaforiza a identificação da experiência particular com a história, fugindo ao típico homem simples, rude e mal-informado de nossas parcas letras.

Malgrado o tom machista presente na obra barretiana, percebido na representação de certas cenas, os juízos deferidos por Gonzaga contemplam uma contraparte mordaz. Com muita freqüência os modelos não podem se aclimatar ao país que os imita de forma capenga. Revelação da componente postiça e canhestra deste solo de todos os donos, fecundo em "idéias fora do lugar" - tomando de empréstimo a idéiasíntese de Roberto Schwarz. Nas palavras de Alfredo Bosi, o romance é uma:

"Pintura animada e crônica mordente da sociedade carioca, esse livro constitui, com o seu visível desalinhavo, a mais curiosa síntese de documentário e ideologia que conheceu o romance brasileiro antes do Modernismo. Gonzaga de Sá vem a ser o espectador a um tempo interessado e cético daquele Rio dos princípios do século, onde os pretensos intelectuais macaqueavam as

\footnotetext{
${ }^{206}$ Embora o tema não seja aprofundado neste trabalho, sugere-se o livro de Eliane Vasconcellos: Entre a agulha e a caneta: a mulher na obra de Lima Barreto. Rio de Janeiro: Lacerda, 1999.
} 
idéias e os tiques da cultura francesa sem voltar os olhos para os desníveis dolorosos que gravitavam ao seu redor; onde a Abolição, sem realizar as esperanças dos negros, prolongou as agruras dos mestiços; onde, enfim, a República, em vez de preparar a democracia econômica, instalou solidamente os oligarcas do campo no tripé de uma burocracia alienada, um militarismo estreito e uma imprensa impotente, quando não venal. A obra é participante e aguerrida desde o título, em que avulta um cacófato ostensivo a desaforar o estilo oficial, purista, dessa época áurea de gramáticas normativas e sonetos neoparnasianos.” (pp. 320-1) 207 $^{207}$

O livro, publicado três anos de sua morte (1919), é a obra em que Lima Barreto talvez melhor tenha conciliado o tom de protesto contra a mediocridade e o egoísmo com a sua técnica de composição. Ou seja, em que logrou reunir de forma mais equilibrada as motivações de cunho ideológico ao poder de fogo da estética. É a primeira ou segunda obra mais refinada de sua produção. E tal consórcio entre “panfletagem” e ficção pode converter o romance - ao lado de Triste fim de Policarpo Quaresma - em seu projeto provavelmente mais bem acabado, como ele mesmo acreditava.

Uma das razões para o predomínio do tom “panfletário” sobre a sua arte, propriamente dita, pode ter sido respondida por Cavalcanti Proença, já que, contrariamente ao estilo ornado de Machado de Assis, em Lima Barreto:

"Raríssimo será o uso da retórica no sentido de ornamento puro e simples. Muitas vezes o estilo se liberta de tal maneira das convenções obedecidas pelos contemporâneos, que se apresenta desataviado como palestra mansa, cheia de parênteses, os parênteses em que o autor pede a palavra no meio de um parágrafo para críticas de ordem geral, a propósito de uma falha do personagem, ou de ocorrências do entrecho.” (p. 40) (208 $^{20}$

Não se deve ignorar o fato de Lima ter publicado a versão definitiva do romance com a idade aproximada de quarenta anos - faixa etária, aliás, em que tem início a famigerada segunda fase de Machado de Assis. Seu estilo, particularmente nesta obra, por vezes se aproximava do romance machadiano, como defende Bosi:

"um encontro mais íntimo com o seu estilo uma que outra semelhança com o andamento da frase machadiana, cuja velada ironia se entremostra nas restrições, nas dúvidas, nas ambíguas concessões à mentalidade que deseja agredir: é a linguagem do 'mas', do 'talvez', do 'embora', sistemática nos romances de Machado, dispersa e isolada na urgência polêmica e emocional desta Vida e morte de M. J. Gonzaga de Sá.” (p. 321) 209 $^{20}$

\footnotetext{
${ }^{207}$ História concisa da literatura brasileira.

208 Op. Cit. A observação de C. Proença poderia ser justificada no prólogo de Lima Barreto ao apresentar sua palestra "O destino da literatura”, em São Paulo, no ano de 1920: "Estão bem a ver que nunca quis fazer uma ou mais conferências, não por orgulho nem por pretender ser mais profundo que os meus confrades que as fazem; mas, só e unicamente, pelo fato de conhecer a minha cidade natal, de alto a baixo, e de estar convencido de que, no tocante a elas, palestras ou conferências, a minha organização literária tinha falhas. De resto, o discurso nunca foi o meu forte.” (Impressões de leitura, p. 53.)
}

${ }^{209}$ História concisa da literatura brasileira. 
O jovem Augusto Machado conhece o velho Gonzaga de Sá numa repartição da multifacetada Secretaria dos Cultos, por ocasião da contenda interposta por um bispo de Tocantins que recebera uma salva de canhão aquém das dezoito a que faria jus, de acordo com os protocolos eclesiástico-militares.

O trecho é longo, mas essencial para apreender um romance que trata de dois amigos unidos não apenas pelo conjunto de afinidades: união como recurso diante da falta de solidariedade alheia. Em destaque, alguns trechos a revelar as sutis ironias do escritor:

“(...) A reclamação foi presente ao ministro dos Cultos, cuja secretária, na longa informação que deu, aludiu à questão das investiduras, à dos bispos no tempo do Império e ao direito canônico, ainda por cima sem nada resolver de definitivo. Ouviu-se o Ministério do Exterior e $o$ protocolo, carinhosamente interpretado e sabiamente, nada adiantava ao caso. Recorreram, então, ao estabelecido na legislação dos países civilizados ou não. (...) Na linda repartição das delicadas coisas internacionais, fizeram sábias transposições de uma religião para outra, de modo a se estabelecer equivalências das respectivas autoridades. Foi organizado um quadro, muito bem feito, bem riscadinho, em que os nomes dos sacerdotes de cada religião foram escritos, respeitando-se a índole ortográfica de suas línguas próprias. O catolicismo, o budismo, o judaísmo, o bramanismo e as seitas protestantes encontravam-se placidamente no terreno das conveniências burocráticas e protocolares. (...) Estava a decidir-se a questão de um modo geral e de vez, quando surge a angustiosa dúvida do cardeal. Seria Sua Eminência uma autoridade eclesiástica brasileira? Devia receber só salvas de arcebispo ou mais outras? Se era autoridade eclesiástica estrangeira, que salvas devia ter? Se era nacional, quais? etc. E assim as interrogações se sucediam nas seções do ministério, quando o meu diretor, para evitar delongas, resolveu mandar-me à Secretaria dos Cultos submeter aos competentes a angustiosa questão cardeal. Pouca gente conhece a Secretaria dos Cultos e tem notícia dos seus serviços. É de admirar que aconteça isso, porquanto, penso eu, se há secretaria que deva merecer o respeito $e$ a consideração da nossa população é a dos Cultos.” (pp. 17-9) ${ }^{210}$

Da mediania de idéias e ineficiência profissional à sabedoria. É nesse conflito que vive a figura que nomeia o romance. Por que ser mais ágil ou demonstrar mais competência que os demais? De que serve refletir e não resolver?

Gonzaga era um bacharel em letras que completara seus estudos no Colégio Dom Pedro II e findaria sua vida, abruptamente, diante de uma flor, após sofríveis quinze anos de convivência com o ambiente medíocre da repartição.

Dono de projetos relativamente ambiciosos - como o de publicar um escrito em que um homem tenta sem êxito fazer decolar uma aeronave - conhecia toda a cidade por suas pernas: experiência possibilitada pela existência inteiramente vivida no Rio de Janeiro, paisagem que amava; cidade cujos hábitos e habitantes, porém, fazia e desfazia sob certeiros juízos de valor.

"Gonzaga de Sá dizia-me: - A mais estúpida mania dos brasileiros, a mais estulta e lorpa, é a da aristocracia. Abre aí um jornaleco, desses de bonecos, e logo dás com uns clichês muito negros... Olha que ninguém quer ser negro no Brasil!... Dás com uns clichês muito negros

\footnotetext{
${ }^{210}$ Vida e morte de M. J. Gonzaga de Sá.
} 
encimados pelos títulos: 'Enlace Sousa e Fernandes (...). Julga que se trata de grandes famílias nobres? Nada disso. São doutores arrivistas, que se casam muito naturalmente com filhas de portugueses enriquecidos. Eles descendem de fazendeiros arrebentados, sem nenhuma nobreza e os avós da noiva ainda estão à rabiça do arado na velha gleba do Minho e doidos pelo caldo de unto à tarde.” (p. 32) $)^{211}$

Cidade com cidadãos aferrados ao projeto de civilização de outrem. Ante o arrivismo, o bovarismo e o atavismo de um bando de homens de civilidade artificial e muito nova para que se sustentasse, Gonzaga de Sá tratava sem dó as feridas expostas pela mediocridade, consolidadas diariamente nas repartições públicas e ainda mais nítidas no caráter compulsório das modas e modismos mal transplantados para o país. Nas palavras de Gilda de Mello e Souza:

“(...) entre todos os elementos que entram em jogo no exibicionismo da festa, a moda é um dos mais eficientes. Uma conexão íntima sempre a ligou às reuniões sociais, pois juntamente com a força física, as armas, a inteligência e os ardis, é a vestimenta um instrumento de luta, quer ela se trave entre os grupos ou entre os sexos.” (p. 151) ${ }^{212}$

Contrariamente aos homens desligados de sua própria origem e história, Gonzaga passara a vida caminhando, como se só em movimento fosse possível alcançar uma maior identidade, numa identificação primária com o território, ainda que asfaltado e repisado por bondes - símbolos de um progresso instantâneo sem tempo de deixar registro, não-histórico. O dado é sério e pode ser resumido nas palavras de Nestor Duarte:

“A nossa idéia de pátria como de nação é, antes de tudo, um complexo geográfico (...) [de] um lirismo exaltado que canta a terra, os rios e as montanhas, [em que] não se encontra quase nunca o elemento histórico.” (p. 125)

Se as palavras do homem Gonzaga contrastam inclusive com relação às suas próprias atitudes, a figura - de acordo com a descrição oferecida por Augusto Machado - não parece destoar tanto da natureza de seu ofício burocrático.

Um conjunto de atividades rotineiras e despachos prolixos o confinam, espremido que está entre a escrivaninha e a janela; entre a terra dos homens novos e o mar - este, único reduto pouco afetado pelo homem sem cultura dos novos tempos. Mar, elemento mais puro, embora associado à tradição e seu peso histórico, com ares de colonizador.

"Foi, por ocasião de desempenhar-me da incumbência do meu diretor, que vim a conhecer Gonzaga de Sá, afogado num mar de papéis, na seção de 'alfaias, paramentos e imagens', informando muito seriamente a consulta do vigário de Sumaré, versando sobre o número de setas que devia ter a imagem de São Sebastião. Era Gonzaga um velho alto, já não de todo

\footnotetext{
${ }^{211}$ Idem.

212 Op. Cit.

213 Op. Cit.
} 
grisalho, mas avançado em idade, todo seco, com um longo pescoço de ave, um grande 'gogó', certa macieza na voz grave, tendo uns longes de doçura e sofrimento no olhar enérgico. A sua tez era amarelada, quase dessa cera amarela de certos círios. Tratei com ele cheio do respeito que, acima da beleza, merece a velhice. Ele me pareceu agradecer a deferência, olhando-me com mal disfarçado interesse, por debaixo do pince-nez, do fundo do abismo da sua banca burocrática.” (p. 19) $)^{214}$

A apatia de Gonzaga favorece a especulação. Prova disso é a poderosa capacidade de reflexão demonstrada pelo narrador, Augusto - segundo degrau de uma escala de valores encimada por um Lima Barreto, que disserta aproveitando a boca das duas personagens. Mecanismo de duas vias que, na ordem inversa, reproduz a necessidade do próprio narrador de falar de si mesmo, citando o inspirador amigo e mestre Gonzaga de Sá. Anoar Aiex lembra que Lima Barreto:

"De Brunetière aceita (...) a noção de que a função social da literatura consiste em orientar a conduta humana e que isso deve ser feito através de uma forma condizente com o conteúdo que pretende expressar. (...) Retomando, pois, a tendência sociológica da literatura brasileira, Lima Barreto desvia-se do caminho mais seguido pelos seus contemporâneos, restabelece a continuidade entre o passado e o presente e mostra a via a ser seguida pelo romance do período modernista." (pp. 46 e 52)

A exemplo do que se pode ler nos demais romances barretianos, em Vida e morte de M. J. Gonzaga de Sá a burocracia é tratada sem piedade. Gestos pomposos e morosos, hábitos enraizados, retomados nos intervalos entre o horário do café. O aparato burocrático só perde terreno para as discretas, mas sublimes relações de amizade, ilustradas neste romance como poucas vezes visto em sua ficção - como bem comprova a especial ligação entre Gonzaga de Sá e o servente-amigo Romualdo.

\section{Morte e vida}

Augusto Machado, narrador-personagem, representa o novo -, não aquele ligado aos homens sem idéias ou ideais. É uma espécie de propagador das idéias do amigo Gonzaga de Sá. Este, tocado negativamente pelos caminhos tortuosos que segue a República, é uma espécie de velho bastião do inconformismo. Fonte de questionamentos pertinentes, converte-se numa espécie de preceptor ideológico do amigo nas vestes de um providencial narrador.

É curioso que, embora o registro seja tarefa de um rapaz de vinte anos, não tenhamos notícia de seus amigos, sequer de seus parentes. Também a ausência de seus pais, em certa medida, favorece o desempenho de Gonzaga de Sá - amigo contraído em

\footnotetext{
${ }^{214}$ Op. Cit.

${ }^{215}$ As idéias sócio-literárias de Lima Barreto.
} 
uma diligência que os vincula pela função pública. Companheiro de caminhadas e reflexões, adquirido por acaso, logo convertido em pai de empréstimo, mais intelectual que afetivamente.

Amizade e paixão. Vida e morte. Dos doze capítulos há um que, embora em aparente discrepância em relação aos demais, sintetiza os principais ingredientes apresentados no romance. É o nono ( $I X-O$ padrinho). Augusto Machado é chamado pelo amigo mais velho a participar da cerimônia funerária de Romualdo de Araújo, servente da Secretaria de Cultos, cujo filho - Aleixo - fora apadrinhado por Gonzaga.

O narrador não fica imune às tentações de Alcmena - figura com nome e cheiro de flor - como se percebe, numa leveza absolutamente contrastante com a atmosfera grave e pesada do cerimonial.

Enquanto Romualdo jaz na caixa funerária - símbolo acabado de desistência e finitude - Augusto experimenta todo o frescor da vida em um discreto erotismo, não de todo interrompido com a saída de Alcmena, mas pela censura de Gonzaga de Sá e a dura frieza do cadáver. Episódio inusitado, em que sobe a temperatura de Augusto pela vida (Alcmena), na mesma proporção que seu descaso em relação ao morto:

"Demais, senti também, era o cadáver que me impelia, que me empurrava para a moça; era a sua mudez de fim que me ditava o único ato da minha vida capaz de fugir à lei a que ele se curvara. Vivente, tinha vivido, pois tanto é forte em nós viver, que só em nós mesmos encontramos a razão e o fim da vida, sabendo nós que devemos continuá-la a todo o transe, custe o que custar, em nós mesmos e nos nossos descendentes. Tive ainda uma ponta de arrependimento, apesar de tudo, pois não sei o que me dizia que fora longe demais...” (p. 72)

A morte não comove Augusto, já que fora convocado às pressas e se trate do enterro de um ente distante. Antes, o contrário. A julgar por seu depoimento, a morte serve de fatalidade que faz pensar e querer viver melhor as oportunidades terrenas.

O velho repara a ausência dupla do jovem convidado, que responde à discreta provocação com um adjetivo (“quente”) revelador de seu estado dicotômico - entre o protocolo sem graça da morte e a iminência do flerte, da beleza e do amor em vida. Como de costume, Gonzaga aproveita o que seria uma constrangedora reprimenda ao rapaz para tratar das coisas mal adaptadas às caras do Brasil:

“- Tens estado pouco na sala.

- Está muito quente...

- Deves ir, não só porque é conveniente à tua mocidade o espetáculo da morte, como também dá campo para se ver como os etnólogos são falsos e maus. Ele tirou uma longa fumaça do cigarro e continuou:

- Ultimamente, disseram que os feitios de sentir eram tão diferentes em cada raça humana, que era o bastante para fazer não se entendessem elas...(...) Ora, em face do nosso povo, tão variado, eu tenho reparado que nada há que as separe profundamente. E nós nos entenderíamos e

${ }^{216}$ Op. Cit. 
preencheríamos facilmente o nosso destino, se não fora a perturbação que trazem os diplomatas viajados, acovardados da opinião americana, querendo deitar esconjuros e exorcismos...” (pp. $72-3)^{217}$

Embora pareça destoar do tom geral do romance, o episódio imprime no leitor uma marcante sensação de falência, antecipando, de certo modo, o tom patético, alinhavado no encerramento do livro. Do ponto de vista de Augusto Machado, o velório poderia ter lhe sido de melhor serventia, já que prenunciava a morte do próprio Gonzaga de Sá - morte, a completar o título do romance.

Esse capítulo é, sem dúvida, o mais denso. Não só pela extensão (empata em número de páginas apenas com o XI), mas pela variedade de assuntos tratados. Nas frases de abertura, o narrador detém-se no tópico "mulheres": principal referencial daquela sociedade, segundo o próprio.

Em seguida, menciona os poucos amigos - na ocasião, reunidos no Café de costume - cuja conversação, presumivelmente animada, é contrastada pela ruptura provocada pela chegada de um Gonzaga de Sá mais abatido que de costume, devido à morte do amigo Romualdo.

Sua sobrecasaca é preta (cor preferida pelos homens daquele tempo, contrários ao advento da República, esta marcada pelos tons mais claros). Revela não só o luto, mas a gravidade redobrada do sexagenário. Não por acaso, é a partir deste capítulo que a narrativa deixa transparecer a gradativa e crescente apatia do amigo de Augusto, quarenta anos mais velho.

No trem, a caminho do local do velório, Augusto Machado reparava no fácil riso dos medíocres e, entre um silêncio e outro, é aconselhado por Gonzaga de Sá a namorar, cultivar o amor. “A doçura é o maior poder da Terra.”

Há ainda espaço para especulações do próprio narrador sobre o papel dos homens (lá comparados a animais de carga). Tais assuntos, aparentemente alheios ao motivo que os leva ao enterro, preparam o destoante interlúdio entre Augusto e Alcmena - a jovem que desperta desejos teoricamente incompatíveis, mas conciliados por ambos com a cerimônia de despedida do servente falecido.

A morte de Romualdo é antecedida pelo encontro de Augusto e Gonzaga, no Café Papagaio. Assim, o contraste entre o sepultamento e a postura de Augusto parece delineado na confrontação entre os espaços. Café, local para jogar conversa fora com os amigos próximos e vivos; velório, espaço de silêncio e boca fechada em respeito ao amigo que se foi. Entretanto, as "visitas e as reuniões sociais não constituem ponto de

\footnotetext{
${ }^{217}$ Idem.
} 
partida para quaisquer eventos”, como observou Osman Lins ${ }^{218}$ a respeito dos romances anteriores.

Retomada a conversa com Gonzaga, este lhe fala das teses equivocadas que importamos e se alastram nos meios de imprensa, ganhando foros de autenticidade, ainda que sem maior fundamentação.

Encerra o capítulo não o enterro de Romualdo (completado no capítulo seguinte, o X), mas a preocupação de Gonzaga de Sá em relação ao futuro de Aleixo, filho do servente falecido. Mirando o presente, volta-se para a criança, símbolo de esperança no futuro. Vale retomar a análise de M. Cavalcanti Proença, a respeitos dos olhos na ficção barretiana, especialmente nesse romance:

“Todas as personagens boas que andam nos seus livros são doces pessoas de olhos doces: é Gonzaga que se vai fanando. 'Os olhos, seus doces olhos perdiam o brilho, apareciam mortiços e ganhavam uma estranha auréola'. Quando lhe morre o compadre, chega ao bar e 'os seus grandes olhos macios e lentos nas órbitas, de uma curvatura regular e suave, estavam vermelhos'." (p. 27) ${ }^{219}$

Vida, morte e vida. Há lugar para todo o tipo de vida; mas como ou o que dizer sobre os mortos? De uma forma ou de outra, os diálogos entre Gonzaga e Augusto, bem como suas especulações, resvalam ou vão dar na sociedade. Nesse sentido, o romance de Lima Barreto se serve do comovente final de vida de um e início do outro: trata-se de apelo duplo que busca assegurar ao escritor chamar a atenção do leitor para questões de fundo que integravam o ideário do próprio Lima Barreto ${ }^{220}$.

Ao paradoxal clima de morte e vida corresponde, no nível narrativo, um enredo que não corresponde ao que se espera de um enredo. Enredo não-enredo. ${ }^{221}$ Mas nem só de enredo carece o romance. Como decorrência, não há uma conclusão, um fecho que envolva os amigos e demais conhecidos do protagonista.

Algumas coisas ficam. Há algo que não se pode concluir, malgrado todas as doses de reflexão semeadas ao longo do livro. Não há exatamente uma razão que demonstre o que implica - nem mesmo para Augusto Machado - a morte de Gonzaga.

\footnotetext{
${ }^{218}$ Op. Cit, p. 38.

219 “Prefácio”, Op. Cit.

${ }^{220}$ Para Antonio Arnoni Prado: “Esse tom paradoxal do narrador solitário que manipula as máscaras, sob as quais autor e personagens se confundem, foi na verdade o traço novo que o livro acrescentou à produção literária brasileira naquele ano de 1919, a ponto de inclusive merecer o prêmio dado pela academia (Op. Cit., p. 4).

${ }^{221}$ Segundo Edward Forster: “Numa estória diríamos - ‘e depois?’; num enredo - 'Por quê?’ Essa é a diferença fundamental entre esses dois aspectos do romance (...) personagens, para serem reais, devem deslizar suavemente, mas um enredo deve causar surpresas.” (Aspectos do romance, pp. 69 e 73)
} 
Parece não ser relevante ao narrador traduzir as conseqüências da morte. A partida de Gonzaga de Sá não acomete as demais personagens - não por acaso, pouco envolvidas afetivamente tanto com Gonzaga quanto com Augusto. Tanto faz viver apaticamente ou ir. Ninguém será atingido porque não se sente a sua perda.

O que sentiu ou fez Augusto Machado, após a morte de Gonzaga de Sá? Não sabemos. Não há exatamente uma trama, senão aquela mal escondida (intencionalmente?) nos vícios dos homens, de uma forma geral. O livro é cheio de meios, mas não parece ter um fim. Não segue a linearidade, por exemplo, do romance de Manuel Antônio de Almeida - este, sorte de romance de formação subvertido -; nem configura uma linha, um centro onde gravitem as ações, como acontece na novela $O$ Alienista. As ações pouco se manifestam, apesar de serem um dos pressupostos de um romance-padrão. ${ }^{222}$

Gonzaga de Sá é não só uma criação a partir do tédio e da somatória de outras insatisfações de Lima Barreto. É refúgio, mas pode ter servido de voz paralela à do próprio autor. O protagonista é um burocrata filosofante - imagem que o escritor talvez perseguisse ou com que se identificasse, de maneira a tornar mais palpável lidar com a configuração de si mesmo.

\section{Injustiçados e oportunistas}

Isaías Caminha, Policarpo Quaresma, Gonzaga de Sá e Augusto Machado são as personagens mais interessantes da ficção barretiana. O jovem com esperanças de tornarse doutor ou jornalista; o homem maduro e ingênuo, cuja repentina lucidez vem assolada pela insanidade e assombrada pela violência do regime político; o velho que desperdiçou sua sabedoria na repetitiva repartição pública; um aprendiz.

Todos representam, em contextos e graus diferenciados, homens desiludidos cujas forças se voltam de maneira desconfiada para o poder da imprensa e os desmandos do governo. Hierarquia via burocracia.

O jornalista frustrado, o ingênuo otimista e os funcionários públicos pouco empregam seu potencial transformador e percebem-se revestidos da indumentária tosca do favor pessoal, convivendo com homens recheados de positivismo de segunda ordem, a par de idéias e modas importadas nos trajes a rigor pelo país agrário e sem escolas.

\footnotetext{
${ }^{222}$ Conforme Álvaro Guerra: [Na novela] "O entrecho deve ser concatenado de um modo mais ou menos lógico e atraente, despertando cada vez mais a curiosidade do leitor até o desfecho que deve encenar sempre uma surpresa. É necessário, nesta espécie do gênero histórico, dar à narração e muito especialmente ao seu desenlace um caráter de novidade para justificar a designação que se lhe aplicou de novela (do francês nouvelle).” (Introdução ao estudo da literatura, p. 40).
} 
Há um nítido agrupamento entre as personagens justas - mais próximas e identificadas ao próprio escritor - e as oportunistas - em geral, bem sucedidas política ou financeiramente. Nas palavras de Cavalcanti Proença, em seu já citado "Prefácio":

"Lima Barreto, parece, dividia as pessoas em boas e más. (...) os que lhe inspiravam ternura, ele os queria sempre iguais e os caracterizava quase pelas mesmas palavras. Doçura e mansuetude, gestos de aves, luz no olhar. Mas a doçura é a grande qualidade, a constante que assinala, ao longo de todos os seus livros, os personagens bons, fictícios ou reais, as coisas, as paisagens, as idéias nobres.” (p. 30)

Na outra mão está, para citar um exemplo, o famigerado professor de Javanês: doutor pouco letrado que obtém com o pomposo e nulo título o respeito dos demais e o perdão de sua dívida. No conto $O$ homem que sabia javanês é relativizado o conhecimento dos homens pseudotitulados, principalmente quando adotados por figuras ligadas ao “generoso” Império.

“- Senhor Castelo, quando salda a sua conta? Respondi-lhe então eu, com a mais encantadora esperança:

- Breve...Espere um pouco...Tenha paciência...Vou ser nomeado professor de javanês, e...

Por aí o homem interrompeu-me:

- Que diabo vem a ser isso, Senhor Castelo?

- É uma língua que se fala lá pelas bandas do Timor. Sabe onde é? Oh! Alma ingênua! O homem esqueceu-se da minha dívida (...)” ${ }^{223}$

Poderia completar esse quadro de avessos, Numa Pompílio de Castro - político carreirista em franca ascensão, cujos atalhos não o levam a outros êxitos; pelo contrário, parecem implicar o nulo valor do casamento de aparências bem como do rodízio de seus aliados políticos.

Personagem comparável ao Palha (Quincas Borba) de Machado, convive pacificamente com o adultério (aqui efetivado), encarnando do modo mais incisivo as maneiras com que Lima Barreto expunha as idéias de utilidade questionável, a desnudar os homens sem escrúpulos de seu tempo.

Campo tirânico num intrincado nicho: aquele das formas canhestras e sem conteúdo, num mote articulado por figuras ávidas por se verem bem instaladas nos bastidores da política ou da notícia - esta, a principal via de acesso da carreira pública ou literária: “quem não aparece no jornal, não aparecerá nem no livro, nem no palco, nem em parte alguma - morrerá. É uma ditadura”224, assinalava o sábio andarilho Gonzaga de Sá.

Figura que nomeia o romance publicado quatro anos antes da pseudobiografia de M. J. Gonzaga de Sá, o major Policarpo namora pateticamente a loucura - via de acesso

\footnotetext{
${ }^{223}$ Lima Barreto. A nova Califórnia - contos, p. 24.

${ }^{224}$ Vida e morte de M. J. Gonzaga de Sá, p. 53.
} 
que o aproxima de certas personagens machadianas vitimadas pela doença-recurso, fruto da lucidez, como Rubião. Dispositivo patológico que permite adentrar, mas não sair sem maiores lesões, dos meandros que sustentam a hipocrisia dos homens.

"Esse encerramento em si mesmo deu-lhe não sei que ar de estranho a tudo, às competições, às ambições, pois nada dessas coisas que fazem os ódios e as lutas tinha entrado no seu temperamento. Desinteressado de dinheiro, de glória e posição, vivendo numa reserva de sonho, adquirira a candura e a pureza d'alma que vão habitar esses homens de uma idéia fixa, os grandes estudiosos, os sábios, e os inventores, gente que fica mais terna, mas ingênua, mas inocente que as donzelas das poesias de outras épocas. É raro encontrar homens assim, mas os há, e quando se os encontra, mesmo tocados de um grão de loucura, a gente sente mais simpatia pela nossa espécie, mais orgulho de ser homem e mais esperança na felicidade da raça. (...) Se os jornais tinham recebido o requerimento com facécias de fundo inofensivo e sem ódio, a repartição ficou furiosa. Nos meios burocráticos, uma superioridade que nasce fora deles, que é feita e organizada com outros materiais que não os ofícios, a sabença de textos de regulamentos e a boca caligrafia, é recebida com a hostilidade de uma pequena inveja.” (p. 54) ${ }^{225}$

Paradoxo cruel, a partir de sua proposta "visionária” - para referir o termo com que Floriano Peixoto, personagem, classifica Policarpo - o major sem experiência de guerra se avizinha de uma inédita e pungente lucidez; estado que divide suas concepções a respeito dos homens, refletindo o severo trânsito de sua existência sem par: Policarpo em tempo de Quaresma.

"Policarpo Quaresma, cidadão brasileiro, funcionário público, certo de que a língua portuguesa é emprestada ao Brasil; certo também de que, por esse fato, o falar e o escrever em geral, sobretudo no campo das letras, se vêem na humilhante contingência de sofrer continuamente censuras ásperas dos proprietários da língua; sabendo, além, que, dentro do nosso país, os autores e os escritores, com especialidade os gramáticos, não se entendem no tocante à correção gramatical, vendo-se diariamente, surgir azedas polêmicas entre os mais profundos estudiosos do nosso idioma - usando do direito que lhe confere a Constituição, vem pedir que o Congresso Nacional decrete o tupi-guarani, como língua oficial e nacional do povo brasileiro. (...)

Demais, Senhores Congressistas, o tupi-guarani, língua originalíssima, aglutinante, é verdade, mas a que o polissintetismo dá múltiplas feições de riqueza, é a única capaz de traduzir as nossas belezas, de pôr-nos em relação com a nossa natureza e adaptar-se perfeitamente aos nossos órgãos vocais e cerebrais, por ser criação de povos que aqui viveram e ainda vivem, portanto possuidores da organização fisiológica e psicológica para que tendemos, evitando-se dessa forma as estéreis controvérsias gramaticais, oriundas de uma difícil adaptação de uma língua de outra região à nossa organização cerebral e ao nosso aparelho vocal - controvérsias que tanto empecem o progresso da nossa cultura literária, científica e filosófica.

Seguro de que a sabedoria dos legisladores saberá encontrar meios para realizar semelhante medida e cônscio de que a Câmara e o Senado pesarão o seu alcance e utilidade P. e E. deferimento. ${ }^{226}$

O documento encaminhado por Policarpo Quaresma - um dos militares nãomilitares brasileiros - revela, portanto, uma das duplicidades inerentes a suas ações. Dicotomias. A exemplo de inúmeras figuras de Machado, o major pertence oficialmente

\footnotetext{
${ }^{225}$ Triste fim de Policarpo Quaresma, 1994.

${ }^{226}$ Idem, pp. 52-3.
} 
ao exército nacional, mas nunca exercera de fato a profissão. Segundo Carmen Figueiredo:

"o hábito de leituras e estudos, a pontualidade e o método contracenando com uma vasta biblioteca já configuram ao leitor algo mais que o ridículo de atitudes; sem dúvida Policarpo é um intelectual movido pelo desejo de conhecimento e saber e isto contradiz o lugar-comum que explica a função do estudo, num país de analfabetos: no Brasil, estudar, conhecer traduz-se por um finis operantis, isto é, reverte-se para uma finalidade prática de projeção e ascensão social. No entanto, o personagem não era doutor e assim para que livros e estudos 'Se não era formado, para quê? Pedantismo!' comentavam os seus vizinhos, como ele também moradores de subúrbio.” (p. 26) 227

Trata-se de pseudo-diplomata sem a malícia requerida pelo poder da persuasão; homem apegado à agricultura, à leitura e à modinha de viola que circula por entre fardados decadentes, artistas frustrados e a desprezada arraia miúda.

Obedece a horários e hábitos rígidos, mas é dono de mentalidade que serve a parodiar os exageros da corrente positivista, francamente apoiado pelos julgamentos negativos do narrador. Menos discreto que Quaresma é o pomposo colega Albernaz:

"O general nada tinha de marcial, nem mesmo o uniforme que talvez não possuísse. Durante toda a sua carreira militar, não viu uma única batalha, não tivera um comando, nada fizera que tivesse relação com a sua profissão e o seu curso de artilheiro. (...) Os seus hábitos eram de um bom chefe de seção e a sua inteligência não era muito diferente dos seus hábitos. Nada entendia de guerras, de estratégia, de tática ou de história militar; a sua sabedoria a tal respeito estava reduzida às batalhas do Paraguai, para ele a maior e a mais extraordinária guerra de todos os tempos." (p. 31) 228

No caso de Policarpo, as contradições de forma e composição começam no nome: homem de fecundos trabalhos e ideais que convive com a melancolia de seu segundo nome; existência mal equilibrada entre o conservadorismo do Império e o novo regime, violentada pelo poder de Floriano - exemplar a personificar a nova ordem sem o mesmo progresso.

Mesmo nas ocasiões em que lhe era reservado o direito à diversão, ao alheamento dos problemas que gradativamente convertem-se no objeto central de sua existência, mal equilibrada entre o nacionalismo ingênuo e a crença nas reformas prometidas pela República, Policarpo parece sentir o peso da manutenção da ordem não aquela sugerida pelo ranço positivista, mas a sua, o equilíbrio pessoal.

No episódio em que veste a máscara para encarnar uma figura da dança Tangolomango, Quaresma passa mal e cai, o que parece revelar o seu desconforto frente à utilização de uma máscara de outra época, marcando seu "encontro com as imagens

\footnotetext{
${ }^{227}$ Trincheiras do sonho - ficção e cultura em Lima Barreto.

${ }^{228}$ Triste fim de Policarpo Quaresma.
} 
desprendidas de suas conexões primitivas”, segundo Carmen Figueiredo ${ }^{229}$. Alceu de Amoroso Lima pontuou o papel das personagens e o tom sombrio das obras do escritor:

"Dos livros de Lima Barreto se evola um grande desencanto de viver. Vencido na vida, inadaptável, comunica à sua literatura um acre perfume de tédio e amargor. Sua obra é uma galeria de caricaturas sociais, magistralmente traçadas. O criador de Policarpo Quaresma, tipo nacional por essência, estiliza o ridículo. Mais do que um ironista, um céptico, ou um revoltado, Lima Barreto é um caricaturista. Ainda nos seus tipos preferidos, aqueles que falam por suas palavras, não desfalece a feição do autor, a quem não escapam os defeitos, os tiques, as fraquezas dos melhores. São homens, e tanto basta (....)” (pp. 14-5) ${ }^{230}$

Deparar com a trajetória de Policarpo leva-nos a aproximá-lo de uma figura quixotesca $^{231}$, mais tarde reformulada no próprio Gonzaga de Sá - ainda mais apático que o primeiro. Como o cavaleiro espanhol, é a partir dos livros que o major Quaresma obtém e reformula seus conhecimentos; é através das modinhas de viola que mantém a proximidade com o elemento popular - raiz da suposta desordem que o novo regime viria regulamentar, taxar, burocratizar.

Na agricultura, entretanto, é que percebe a cruel conjugação entre os mais e menos favorecidos - fato que relembra a necessidade da reforma agrária. Num carrossel incessante, aos momentos de otimismo, sobrevêm os fatos, a realidade. Segundo Osman Lins:

“o herói, ao mesmo tempo que abandona o cenário da sua desastrada experiência, vai empreender uma nova forma de ação, voltada agora simplesmente para a terra e não mais para a sociedade. Mas os desastres também não tardam nessa outra conjuntura: a terra não produz e as saúvas aferroam o lavrador improvisado com uma violência que evoca a reação geral ao seu infeliz requerimento.” (pp. 38-9)

Quando se dá conta do pouco caso a que foi submetida a sua petição para o emprego do tupi-guarani como língua oficial do Brasil, Policarpo - em eterno tempo de Quaresma - volta-se para outra crença batida: a da fertilidade de nossos solos, talvez como forma simbólica de compensar a infertilidade de idéias mal colocadas na mente estreita dos homens que, paradoxalmente, encabeçam a pátria e sobre tudo legislam.

\footnotetext{
${ }^{229}$ Trincheiras do sonho - ficção e cultura em Lima Barreto, p. 60.

230 “Introdução” In: Lima Barreto. Vida e morte de M. J. Gonzaga de Sá. Ediouro, s/d.

${ }^{231}$ Segundo Oliveira Lima: “o Major Quaresma viverá na tradição, como um Dom Quixote nacional. Ambos são tipos de otimistas incuráveis, porque acreditam que os males sociais e sofrimentos humanos podem ser curados pela mais simples ao mesmo tempo mais difícil das terapêuticas, que é a aplicação da justiça da qual um e outro se arvoraram paladinos.” (Op. Cit., p. 9)
} 


\section{Sobre o mar}

Mal acomodada à apagada carreira pública, a pacatez de Gonzaga caminha pelos pés de andarilho, redescobrindo lugares discretos da cidade, arejando também a mente de Augusto Machado, narrador que faz suas as reflexões do amigo sexagenário. Sua necessidade de caminhar talvez fosse uma maneira de compensar o aprisionamento no gabinete e reencontrar a si mesmo, solitário, afastado dos forçosos assuntos limítrofes de seus colegas de ofício.

Em seu horizonte, contrafeito diante das mesquinharias com que, bem ou mal, resolveu conviver empregando-se na burocracia, o mar. De fato, a visão do oceano é freqüente, nesse romance. $\mathrm{O}$ mar $^{232}$, em seu caso, de dupla feição: repetitivo, dia e noite, perfazendo uma das mais instigantes rotinas da natureza. Mas os movimentos de inda e vinda, apesar de perenes, jamais se repetem no desenho. Ciclo e inovação, substantivos que se refletem no burocrata e revolucionário Gonzaga.

Ao longo da orla, chega-se às ruas que levam à Secretaria onde Gonzaga de Sá trabalha. Críticas à burocracia e aos consideráveis períodos de ócio que caracterizavam determinados cargos na carreira pública são colocadas no caldeirão aceso por um e outro, Gonzaga e Augusto, como se a imutabilidade de certas coisas se perpetuasse de uma geração à(s) seguinte(s):

"Quando fui à Secretaria dos Cultos tratar da questão do cardeal, falei em primeiro lugar, como era natural, com o diretor-geral dos cultos católicos, o barão de Inhangá. Era um velho funcionário do tempo do Império que se fizera diretor e barão, graças ao seu nascimento e à sua antigüidade de funcionário. Homem inteligente, mas vadio, nunca entendera daquilo nem de coisa alguma... Entrara como chefe de seção e durante as horas de expediente o seu máximo trabalho era abrir e fechar a gaveta da sua secretária. Foi feito diretor e, logo que repimpou no cargo, tratou de arranjar outra atividade. Em falta de qualquer mais útil aos interesses da pátria, o barão fazia a toda hora e a todo instante a ponta do lápis. Era um gasto de lápis que nunca mais se acabava; mas o Brasil é rico e aprecia o serviço de seus filhos. (...) Reparei que, antes de escrever, o magnífico chefe das 'Alfaias e Paramentos' meneou a caneta ao jeito de um esgrimista e pareceu-me que a tinta lhe ia pingando do nariz úmido e vermelho. O seu cursivo, ao fim de minutos, naquelas minguadas letras, surgiu caprichoso, floreado e abundante de uma respeitabilidade de escritura caldaica.” (pp. 45-6) ${ }^{233}$

O repetir burocrático; o abrir-e-fechar de gavetas de um; a assinatura à base de torneios de outro; os modos de falar e escrever, na hora de despachar os processos. Toda a mesmice remunerada contrasta com os espaços abertos. Essa parece ser uma das razões para a constante referência do narrador ao mar, que se estende e contagia a paisagem.

${ }^{232}$ Cavalcanti Proença (1956) e Antonio Candido (1976) também chamaram a atenção para a embarcação (barco ou barca): “símbolo de evasão”, segundo o primeiro; “'poderosa nau’ e seu correlativo terrestre, a 'grande casa solarenga'”, conforme o segundo. 
Ver o mar é deixar aos competentes destrinchadores a fixidez da escrivaninha, um dos símbolos do emprego público. Daí o relevante papel de um Xisto Beldroegas, por exemplo: personagem que revela o avesso, na ótica de Augusto e Gonzaga. A observação de Carmen Figueiredo é notável:

“A situação em que se insere Xisto Beldroegas dá à burocracia uma aura de cientificidade, a partir do princípio de que os fatos podem ser verificáveis pela sua repetição e constância, daí adquirem valores absolutos e verdadeiros. A prática deste personagem pretende dar legitimidade ao falso. Esta concepção nega uma das ricas características humanas: a capacidade de influir, poderosamente, transformando o rumo das coisas. Torna os homens meros repetidores de fórmulas, ao mutilar-lhes o pensamento e a ação.” (p. 54) ${ }^{234}$

O temperamento de Gonzaga de Sá lembra o do cronista Machado de Assis, com o seu gosto de "catar o mínimo e o escondido”. De certo modo, o diplomata barretiano não ignora que nos detalhes é que se imiscuem determinadas chaves que auxiliam na percepção da rudeza inerente aos jogos sociais.

"Lembrei-me então duma frase de Gonzaga de Sá. Disse-me ele uma vez no Colombo: - Estás vendo estas mulheres? (...) - Estão se dando o trabalho de nos polir. De fato, elas nos traziam as modas, os últimos tiques do boulevard, o andar dernier cri, o pendeloque da moda - coisas fúteis, com certeza, mas que a ninguém é dado calcular as reações que podem operar na inteligência nacional. A sua missão era afinar a nossa sociedade, tirar as asperezas que tinham ficado da gente dada à chatinagem e à veniaga dos escravos soturnos que nos formaram, era trazer aos intelectuais as emoções dos traços corretos apesar de tudo, das fisionomias regulares e clássicas daquela Grécia de receita com que eles sonham (...) continuadoras de algum modo da missão dos conquistadores.” (p. 62)

Andar desacompanhado é trocar o coleguismo forçado e hierarquizado da repartição (espaço que divide, a começar pelo nome) pela segurança da solidão honesta. Estar só para melhor absorver a brisa, o vento que renova e chega pelo mar, à margem do elemento fixo, urbano.

Estar só para mais rápido se desvencilhar dos conhecimentos que se repetem e desvendar os recantos menos visitados da cidade que poucos conhecem como o próprio amanuense. De Gonzaga para o próprio Lima:

“(...) eu, apesar de ser um sujeito sociável e que passo, das vinte e quatro horas do dia, mais de quatorze na rua, conversando com pessoas de todas as condições e classes, nunca fui homem de sociedade: sou um bico-do-mato" (pp. 54-5) ${ }^{236}$

Como autêntico irradiador das idéias do amigo falecido, também Augusto Machado volta e meia destila o travo contra determinadas instituições, alimentando-se de alguns comportamentos percebidos nas repartições públicas, nos bondes etc: “Gente

\footnotetext{
${ }^{233}$ Op. Cit.

${ }^{234}$ Lima Barreto e o fim do sonho republicano.

${ }^{235}$ Op. Cit.
} 
fácil de rir-se, pensei eu. Enfim, o riso brota de acordo com a inteligência de cada um.” (p. 65) $)^{237}$

A sabedoria de Gonzaga de Sá capta de forma certeira particularidades presentes em determinados comportamentos universais, revelando o seu gosto pelas máximas, relembrando determinados narradores machadianos.

"Morto um preconceito ou uma superstição, nasciam outros. Tudo na Terra concorre para criálos: a Arte, a Ciência e a Religião são as suas fontes, são as matrizes de onde saem, e só a morte dessas ilusões, só o esquecimento dos seus cânones, dos seus delírios e dos seus preceitos, trariam à humanidade o reino feliz da perfeita ausência de todas noções entibiadoras. Seria assim? Não ficariam algumas? Não era mesmo da essência da natureza humana ter cada grupo o seu stock para opor às do vizinho?” (p. 85) ${ }^{238}$

Com energia superior àquela empregada em abordar os temas mais abrangentes, o sábio se volta contra a limitação de seus colegas de ofício e ócio, perfazendo o percurso inverso - da inépcia particular de uns para a mediocridade: esta, em escala que parece escapar ao âmbito nacional:

“- Quem te disse que eu estava doente?

- Já te disse... O Xisto Beldroegas.

- Que idiota! Com aquela voz de castrado, com aquele passo de jabuti... Tenho-lhe nojo, nojo da sua burrice... Imagina que, para me moer, ele se propôs um dia a discutir filosofia com o

Baltar... Sabes o que discutiram?

- Não.

- Ouve, Beldroegas diz ao outro, olhando de esguelha para mim, 'Baltar, vamos discutir filosofia.' Baltar tosse, Beldroegas faz um esforço para falar, cacareja e pergunta: 'Como morreu Sócrates?'. Felizmente, eu escapei de ser doutor...” (p. 90) $)^{239}$

É sintomático: na ficção barretiana, onde existir um grupo de amigos haverá uma oportunidade em que se perceberá o gosto pelo grau, pelo poder de deter e domar, tomando para si, a razão e o conhecimento sobre determinados assuntos.

Em tais reuniões - ainda que nos locais a que também têm acesso os mais pobres - é freqüente a alusão de uns e outros ao anel que carregam no dedo. Ao anel de grau corresponde, de forma caricata, o gosto pelos epítetos que servem a elogiar o próprio portador de títulos e favores.

Uns e outros parecem motivados quase que exclusivamente por reafirmar, ainda que de forma a contrastar com o mar de misérias a que consideram como cerco, sua casta, sua classe social, tomando como discurso de defesa a manutenção da ordem,

\footnotetext{
${ }^{236}$ Palestra "O destino da literatura”, Op. Cit.

${ }^{237}$ Op. Cit.

${ }^{238}$ Op. Cit.

${ }^{239}$ Op. Cit.
} 
muitas vezes confundida com o abuso da autoridade, o mandonismo sem contestação e o poder, também assegurado na fina hierarquia.

Em oposição aos grupos reunidos no bonde ou na repartição, a solidão nas ruas, o encantamento propiciado pelo mar. As caminhadas de Gonzaga de Sá não seguem em direção à multidão, por isso mesmo. Assim como o "promeneur solitaire” de Rousseau, em lugar de procurar eventuais companhias para uma prosa sem rumo, o amanuense perambula só, como se apercebido de que para melhor captar a essências das coisas fossem elas paisagem ou pessoas - era mais produtivo contar com as próprias pernas, a própria percepção, evitando, assim, o alarde, o ruído, a interferência do olhar alheio. ${ }^{240}$

Por conhecer sobremaneira a cidade em que vive, Gonzaga exerce uma espécie de domínio sobre o espaço; não o domínio exploratório, característico da re-urbanização que atravessava o Rio de Janeiro, na virada do Império para a República. É também a opinião assinalada por Anoar Aiex:

"Vivendo em pleno regime republicano, Lima Barreto sente certa nostalgia da época imperial, mostrando desconfiança com respeito aos políticos da República, considerados por ele oportunistas e inferiores aos do Império. Serve-se, pois, dessa visão idealizada do passado, para atacar a urbanização do Rio iniciada durante a República, por considerá-la imitativa da arquitetura estadunidense.” (p. 49) ${ }^{241}$

O livro não apresenta uma trajetória linear. Aparentemente ninguém chega a lugar nenhum. Mas, cada diálogo ou pensamento formulado é registrado e incorporado à narrativa, como necessidade, como parte desta, autêntico protesto, panfleto em fogo brando. “Não há enredo”, afirmaria Paulo Rónai, em "Prefácio” a uma das edições do romance.

Se Gonzaga de Sá é grave e sisudo, o que condiz com o seu modo de andar contemplativo e os trejeitos especulativos; se é perceptível o cuidado do autor na composição dessa e das demais personagens principais, não deixa de se evidenciar a forma rude e grotesca com que é introduzido um batalhão de medíocres, todos

\footnotetext{
240 "Só, incompreendido, amargo, mantendo a custo a máscara do riso, desaparelhado para a luta social, Gonzaga fala pelo autor.” (p. 15). A opinião é de Tristão de Ataíde. Palavras do próprio Gonzaga de Sá: “O gênio é Rousseau, não são os suíços.” (Op. Cit., p. 44).

${ }^{241}$ As idéias sócio-literárias de Lima Barreto. As seguintes palavras de Gonzaga de Sá condizem com a opinião do crítico: “- Pense que toda a cidade ter a sua fisionomia própria. Isso de todas se parecerem é gosto dos Estados Unidos; e Deus me livre que tal peste venha a pegar-nos. O Rio, meu caro Machado, é lógico com ele mesmo, como a sua baía o é com ela mesma, por ser um vale submerso.” (p. 37). Op. Cit. Conforme Boris Fausto: "O ideal republicano (...) teve livre curso nos dois movimentos pela Independência, a partir de fins do século XVIII, associando-se à idéia de revolução e de algum tipo de reforma da sociedade." (História do Brasil, p. 227).
} 
devotados à lei das aparências, quesito essencial ${ }^{242}$, como se percebe em Xisto, colega de Gonzaga de Sá. Nas palavras de Carmen Figueiredo:

"Uma figura de trejeitos ridículos e, no mínimo, tão esquisita quanto o seu nome - Xisto Beldroegas -, é projetada no espelho deformante, cuja moldura nada mais é que a ordem burocrática. Para realizar seu intuito demolidor de falsas concepções, oriundas do monopólio da instituição burocrática, o satirista recorre à ironia através da provocante denominação de 'Secretaria dos Cultos'. (...) Xisto Beldroegas representa, portanto, uma realização caricatural, sem ingenuidade, de típico teor satírico.” (p. 53) 243

Mediocridade, conceito da maioria. Enquanto nas Memórias de um sargento de milícias, o ambiente urbano de certa forma se justifica (ou se vê justificado) pelos eventos festivos, visitas entre comadres, aventuras e perseguições de Vidigal; enquanto na novela de Machado, a vila serve de modesto palco a contrastar com a nada discreta Revolução dos trezentos Canjicas, em Vida e morte de M. J. Gonzaga de Sá, o espaço urbano $^{244}$ favorece o realce dos elementos naturais - notadamente o mar - cuja imensidão remete às reflexões de Gonzaga, duplamente sujeito: subordinado e sem espaço na nova ordem de velocidade e pedra.

O mar de Gonzaga, vale lembrar, é o mesmo que serviu de berço flutuante a Leonardinho; e é também por via marítima que a vila, ocupada e dominada pelo Dr. Bacamarte, liga-se cultural e politicamente à sede do Reino que lhe emprestara o poder de mandar para curar.

Se o hábito de Gonzaga de caminhar também resultava da necessidade de se ver circulando num espaço aberto, em oposição à opressora repartição pública - ao abrigo de companhias conformadas à manutenção da hierarquia burocrática -, a contemplação do mar implica valorizar a natureza como elemento "histórico", através de uma nostálgica vinculação à própria fundação da cidade que ele, um Sá, domina. Seres reflexivos não combinam com as festas. Para Gilda de Mello e Souza:

"Nas sociedades urbanas do século XIX, os indivíduos se acotovelam na aproximação física das cidades; contudo, a hierarquização limita cada indivíduo à existência em sua classe, fazendo-o perder o contato com o resto da comunidade. E, se a festa adquire importância, é por anular de

\footnotetext{
${ }^{242}$ Tais personagens, segundo Carmen Figueiredo, são: “Em síntese, profundamente coerentes com o seu tempo, conhecem a importância da imagem sobre o real. É preciso fazer de conta que, dialogar com a noção de valor inculcada em nosso imaginário, transitar entre a representação e a realidade, ser um misto de feiticeiro, adivinho diante dos inúmeros fetiches do cotidiano, para fabricar a imagem.” (p. 66) In: Trincheiras do sonho - fiç̧ão e cultura em Lima Barreto.

${ }^{243}$ Lima Barreto e o fim do sonho republicano.

244 Segundo Rodriguez Lopes: “O espaço urbano ganhava novas significações com as alterações promovidas pelos festejos públicos e representava simbolicamente uma sociedade em que poucos tinham acesso ao poder e às benesses da Coroa, em um momento em que ficava evidente o processo de concentração de renda no âmbito da cidade. O espaço vivido estava marcado pelo espetáculo, onde prevalecia prosperidade, luxo e riqueza, mas também exclusão espacial e simbólica da maior parte da população.” (Op. Cit., p. 67)
} 
certa forma os afastamentos no espaço social.” (p. 156) $)^{245}$

Mar em oposição à terra firme: solo, tablado das convenções sociais mal imitadas a partir dos moldes europeus, sob o disfarce das conservadoras novas idéias do regime republicano. Nesse sentido, as embarcações avistadas por Gonzaga - que relembram o descobrimento do litoral brasileiro - simbolizam uma autêntica contraposição às novidades de então; de passagem, feito os bondes.

Ponto de fuga, a imensidão do Oceano não condiz com a burocracia estreita, que começa na repartição pública, irradia-se por entre as pessoas e contamina as ruas da capital em formação: vitrines em que roupas e idéias, num relativo acordo com os novos tempos, circulam mais por afetação que por propriedade, direito ou dever.

Em lugar de correr, vagar. Divagar. Caminhar num ir e vir feito o mar. Caminhar também é resistir já que, em tese, permite uma ponderação mais calma e melhor apurada das coisas, numa época em que refletir talvez soasse incompatível com a velocidade dos bondes, a modernização feita às pressas e a atualização sócio-cultural forçada, abrupta, no país-fragmento.

O caminhar solitário serve igualmente a burlar não só a companhia dos demais colegas burocratas de rotina única e trajeto imutável. Constitui uma reação simbólica (o eu contar consigo mesmo) ao aparente súbito despertar do espírito de intensa sociabilidade em território urbano. Postura, esta, também aportada pelos bondes apinhados de ternos brancos, vestidos sem armação e chapéus dançantes, em lugar das antigas casacas sombrias, vestidos armados e cartolas. Império a cavalo; República em ritmo de bonde.

A temporalidade, nesse romance, vincula-se à caracterização e à postura das personagens. A Gonzaga - possível símbolo do declínio, do passado, do banzo, da tibieza e do pessimismo - ajusta-se pela contraposição o jovem Augusto, símbolo do futuro, da força, do otimismo. Gonzaga, finitude. Augusto, apogeu.

\section{Três tempos}

Se o “jeitinho" resumiria as peripécias vistas nas Memórias de um Sargento de Milícias, e o “abuso de poder” define os jogos presentes em O Alienista, “solidariedade” é o mote perseguido tanto por Gonzaga de Sá quanto Augusto Machado, no romance barretiano.

\footnotetext{
${ }^{245}$ Op. Cit.
} 
Enquanto Manuel Antônio de Almeida mais descreveu e Machado de Assis mais aprofundou os "fatos" mencionados em suas histórias, o romance de Lima Barreto tende ao subjetivismo, fugindo ao passeio panorâmico porque concentrado na ruptura com os protocolos sociais. $^{246}$

A essa diferença de conteúdos correspondem estruturações diversas, associadas aos gêneros também diferenciados. Nas crônicas do Rio de Janeiro e Itaguaí (caso dos dois primeiros) relativiza-se a seriedade da disputa e manutenção do poder. Nas memórias pessoais apresentadas por Augusto Machado adensa-se a preocupação em desvelar a severa limitação imposta pela convivência em sociedade.

As personagens-símbolo de cada livro estão mais ou menos envolvidas com as formas de poder. Ao peralta de Manuel Antônio de Almeida sucede o louco de Machado e o sábio barretiano. Em certa medida, o folião carnavalesco é uma imagem parcialmente despertada por Leonardo-filho, quando acompanha as comemorações religiosas promovidas no centro ${ }^{247}$ da capital do país.

Folia é igual à loucura, lembra Roberto DaMatta (p. 110). Assim sendo, é plausível associar a cata da loucura, motivação maior de Simão Bacamarte, às folias da vila que domina (mesmo porque ninguém leva seus papéis a sério, em Itaguaí).

Todos os habitantes - travestidos em insanos da ala do barbeiro ou dos dragões da guarda real - mascaram-se, atuam, com vestes e discursos sérios, como se formulassem, de uma perspectiva contrária, uma festa "de entrudo". De acordo com Rodriguez Lopes:

"os vários festejos de cunho religioso e/ou civil, organizados durante o período joanino, ocorreram no mesmo espaço em que se entrelaçavam negócios e tensões sociais. As diversas comemorações da monarquia significaram a reapropriação política e simbólica dos traçados e da ambiência urbanos. (...) os festejos da monarquia apresentavam duplo caráter: lugar de debate político e lugar de interlocução social, especialmente entre monarca e súditos. Mas há ainda a dimensão do espetáculo e da sedução: meio eficaz tanto para a celebração da monarquia e da figura do Rei, como 'cabeça do corpo político', quanto para que segmentos sociais, na maior parte das vezes em torno do Rei, possam ganhar ou reforçar sua legitimidade.” (pp. 28-9) ${ }^{248}$

Se Leonardo-filho não se fixa em lugar algum, Bacamarte e Gonzaga convertem suas casas em verdadeiras fortalezas de sentidos diferentes, o que favorece uma analogia entre a forma internalizada de seu saber (os estudos do médico; as leituras dos

\footnotetext{
${ }^{246}$ H. Pereira da Silva observou a respeito de Lima Barreto que: "Sua aversão ao anel de grau tem raízes psicológicas ligadas ao seu status social não alcançado. (...) Lima Barreto desejou o anel de grau vistoso no dedo anular da mão esquerda, mais que as suas negativas refletem essa frustração.” (Lima Barreto escritor maldito, p. 33)

${ }^{247}$ Emílo C. Rodriguez Lopes lembra que "No centro da cidade encontravam-se a administração pública e os quartéis.” (Festas públicas, memória e representação, p. 25)

${ }^{248}$ Op. Cit.
} 
jornais de província do andarilho) e a própria morada. ${ }^{249}$

Ao rememorar a trajetória compartilhada com o admirado amigo Gonzaga de Sá, Augusto Machado aproveita a oportunidade para interpor às reflexões do sexagenário, pensamentos tão ou mais densos, de sua própria autoria, esta explicitamente barretiana.

"Durante meia hora, fiz um detido exame dos meus atos passados e fui colhendo as suas analogias com o meu ambiente pátrio. Tinha sido vário em seus aspectos e descuidoso como a irregularidade do meu solo natal. Sorrira com a baía, entre triste e alegre; e tive debaixo desse sorriso uma réstia da energia daquelas rochas antiqüíssimas. Diante da serra dos Órgãos, cujo grandioso anseio de viver em Deus fui sentindo desde menino, aprendi a desprezar as fofas coisas da gente de consideração e a não ver senão a grandeza de suas inabaláveis agulhas que esmagam a todos nós. Fui bom e tolerante como o mar da Guanabara, que recebe o bote, a canoa, a galera e couraçado; e, como ela, tranqüila sob a proteção de montanhas amigas, fiz-me seguro à sombra de desinteressadas amizades. Quis viver muito, tive ímpetos e desejos, nas suas manhãs claras de maio, mas o sol causticante do seu verão ensinou-me (antes que M. Barrés mo dissesse) a sofrer com resignação e a me curvar aos ditames das coisas, sempre boas, e dos homens, às vezes maus.” (p. 22) 250

O narrador Augusto Machado mais parece um repórter que entrevistando o próprio autor (no papel da personagem Gonzaga de Sá) de quebra deixasse escapar considerações, na maior parte das vezes, complementares às do "entrevistado" (aspas minhas), por mero gosto de Lima Barreto de ilustrar, deixar claro o que se pretendeu dizer de sério, aproveitando-se ideologicamente do campo ficcional. ${ }^{251}$

Tendo se servido das vozes do jovem e do idoso, ambos inconformistas, o escritor possivelmente intitulou o romance de modo a contemplar o saber equilibrado entre a força do jovem e o desespero rebocado pela velhice. Vale a observação de Osman Lins:

"biografado fictício e seu fictício cronista (...) viriam ambos de um molde comum, seriam ambos o mesmo indivíduo impreciso, dividido, extraviado num mundo indiferente e por vezes reconhecendo-se, num lampejo, fora de si, no outro, em que este reconhecimento de modo algum restaure a sua unidade.” (p. 45) $)^{252}$

\footnotetext{
249 "Como a cidade, como o templo, a casa está no centro do mundo, ela é a imagem do universo." (Chevalier, Op. Cit., p. 196).

${ }^{250}$ Op. Cit.

${ }^{251}$ De acordo com T. Eagleton, no final do século XVIII, duas eram as percepções sobre o papel da literatura: "Na Inglaterra, um utilitarismo grosseiramente filisteu passa rapidamente a ser a ideologia predominante da classe média industrial, que toma como fetiche o fato, reduz as relações humanas a trocas de mercadorias e rejeita a arte como ornamento pouco lucrativo. A cruel disciplina do início do capitalismo industrial (...) não aceitou nada que, no mercado aberto, não pudesse ser transformado em mercadoria. (...) Frente a essas forças, o privilégio concedido pelos românticos à 'imaginação criativa' pode ser visto como algo consideravelmente mais importante do que o escapismo ocioso. Pelo contrário, a 'literatura' surge agora como um dos poucos encraves nos quais os valores criativos expurgados da face da sociedade inglesa pelo capitalismo industrial podem ser celebrados e afirmados (...) A própria arte literária passa a ser vista como uma unidade orgânica misteriosa, em contraste com o individualismo fragmentado do mercado capitalista: ela é espontânea e não calculada racionalmente, criativa, e não mecânica.” (Op. Cit., p. 26)

${ }^{252}$ Op. Cit.
} 
O título ganha, assim, um significado poderoso: na vida e na morte, de uma à outra, de Augusto a Gonzaga; uns, ao modo do primeiro; outros, à maneira do segundo; finalmente, os demais a operar a síntese entre o proceder do antigo e do novo. Novidade relativa: entre a República e o Império, nos intervalos mais ou menos previstos pela rotina do funcionário público - não por acaso, um amanuense, cargo ocupado pelo próprio Lima Barreto, até o fim de sua vida.

"Manuel Joaquim Gonzaga de Sá era bacharel em letras pelo antigo Imperial Colégio Dom Pedro II. Possuía boas luzes e teve sólidos princípios de educação e instrução. Conhecia psicologia clássica e a metafísica de todos os tempos. Comparava opiniões do visconde de Araguaia com as do senhor Teixeira Mendes. Sua história sentimental é limitada. Não foi casado, esqueceu-se disso; embora tivesse amado duas vezes: a primeira, à filha de um visconde, num baile de um marquês; a outra, uma sua lavadeira, não sabe em que ocasião. (...) Aliava a tudo isso uma estóica despreocupação da notoriedade, ou melhor, da posição fácil e barulhenta. Filho de um general titular do Império, podia "ser muita coisa"; não quis. Era preciso ser doutor, formar-se, exames, pistolões, hipocrisias, solenidades... Um aborrecimento, enfim....Não quis; fez-se praticante e foi indo. Foi empregado assíduo e razoável trabalhador. A República veio encontrá-lo quase só na seção, redigindo um decreto do Defensor Perpétuo e, ao lhe avisarem: "Seu" Gonzaga, hoje não se trabalha; o Deodoro, de manhã, proclamou a República no Campo de Sant’Anna: - Mas qual? - perguntou. (...) (p. 26) ${ }^{253}$

A sapiência de Gonzaga de Sá resvala no estilo de vida de um modesto funcionário público, sem perspectivas. Aparentemente entregue à velhice em fogo brando, é ao fim da vida que pode exteriorizar seu inconformismo frente à pomposa mediocridade vigente. A exemplo do Conselheiro Aires machadiano, Gonzaga lida com a “imobilidade do lugar vitalício”, de que fala Márcia Lúcia Guidin. ${ }^{254}$

É que a hierarquia - conceito que ultrapassa os valores morais e quesitos individuais (idade, experiência e sabedoria) - constitui um dos ingredientes que preside às formas de poder, sejam elas estabelecidas na política, na profissão etc.

"Há muita gente que, sem queda especial para médico, advogado ou engenheiro, tem outras aptidões intelectuais que a vulgaridade do público brasileiro ainda não sabe apreciar, animar e manter. São filósofos, ensaístas, estudiosos dos problemas sociais e de outros departamentos da inteligência, para os quais a nossa gente que lê não se voltou e de que são amadores poucos da elite, e sem eco na nação, em virtude dessa pasmosa diferença de nível que há entre a inteligência dos grandes homens do Brasil e da sua massa legente. Certos de que as suas aptidões não lhes darão um meio de vida, os que nascem tão desgraçadamente dotados, se pobres procuram o funcionalismo, fugindo ao nosso imbecil e botafogano doutorado. Não são muitos; são raros em cada repartição, mas consideráveis em todo o funcionalismo federal. (...) O futuro escriturário não dava para o rodapé; declarou-se 'besta', e fez um concursozinho de amanuense, e foi indo. Ficou como um escolar que sabe geometria a viver numa aldeia de gafanhotos; e, quinze anos depois, veio a morrer, deixando grandes saudades na sua repartição. Coitado, diziam, tinha tão boa letra!” (pp. 26-7) $)^{255}$

\footnotetext{
${ }^{253}$ Op. Cit. "em 1822, o presidente do Senado exprimiu à S.M.I. o desejo unânime de celebrar esse dia memorável, oferecendo-lhe, por aclamação do povo, o título de Imperador Constitucional e de Defensor Perpétuo do Brasil. [O conteúdo do] discurso correspondia a um momento histórico preciso, o do nascimento de uma monarquia que não de direito divino.” (Maria E. de B. Ribeiro, Op. Cit., p. 77)

${ }^{254}$ Armário de vidro: a velhice em Machado de Assis, p. 59.
} 
A ficção barretiana aponta para um traço de nossa constituição, socialmente falando. Como afirma Roberto DaMatta: “o maior temor social no Brasil é o de estar fora de lugar, estar deslocado, especialmente quando esse deslocamento implica se fazer passar por algo diferente do que se é realmente.” (p. 171) ${ }^{256}$

Em Vida e morte de M. J. Gonzaga de Sá, não fosse a companhia de Augusto Machado - sorte de aprendiz de mente quase tão fértil quanto o mestre - Gonzaga não teria a quem deixar os seus posicionamentos para a posteridade. Dado o eixo sóciopolítico e cultural em que se centram as considerações das personagens, ambos os sábios pouco falam em dinheiro ou amor: capítulos discretos, como se sabe, na vida do próprio autor. O tom do romance é de solidão e impotência. O que melhor se pode sozinho? Daí a fina consideração de Osman Lins:

"Gonzaga de Sá, nas últimas páginas do livro, faz confidências a Machado. Coisa notável: a confidência, ato anormal nesta ficção de seres ilhados em si mesmos, é interpretada como sinal de fraqueza. (...) Ressurge portanto neste romance a lei que estabelece entre as personagens um vácuo intransponível, impermeável, segregador, isolando-as em si mesmas. Apresentaria tal norma, no romance (...) uma variação, expressa nas cambiantes correspondências e fusões entre o biografado fictício e seu fictício cronista: viriam ambos de um molde comum, seriam ambos o mesmo indivíduo impreciso, dividido, extraviado, num mundo indiferente e por vezes reconhecendo-se, num lampejo, fora de si, no outro, sem que este reconhecimento de modo algum restaure a sua unidade.” (p. 45)

Se em Manuel Antônio de Almeida e Machado de Assis percebe-se que a obra pode ilustrar detalhes de sua vida, em Lima Barreto ocorre praticamente o inverso: em boa parte, é a vida que faz a obra. Por isso, na maioria dos casos, aqueles que se dedicam ao estudo de sua obra, terminam por vincular ficção e verdade.

Não parece um exercício descabido, mesmo porque particularmente em Vida e morte de M. J. Gonzaga de Sá há muito de Lima Barreto no narrador e na personagem que nomeia um romance consideravelmente diverso dos padrões romanescos da época. Segundo Antonio Arnoni Prado, principalmente nesse livro:

“(...) é que se amplia a mobilidade narrativa da impressão e do fragamento como atributos elocutórios da memória, procedimentos que despontaram em Lima Barreto já em seu romance de estréia, as Recordações do escrivão Isaías Caminha, de 1909, em que se manifesta claramente a intenção de não fazer romance à maneira tradicional.” (p. 5) ${ }^{258}$

Lima Barreto ressente-se dos homens, também porque a recepção a sua produção é em boa parte prejudicada pela conformação de um público cuja apreciação,

\footnotetext{
${ }^{255}$ Vida e morte de M. J. Gonzaga de Sá.

${ }^{256}$ Op. Cit.

${ }^{257}$ Lima Barreto e o espaço romanesco.

${ }^{258}$ Op. Cit.
} 
orientada pela crítica, supervalorizava a estética - critério, esse, filtrado pelas mãos de estudiosos e historiadores espalhados nos periódicos de renome e manuais literários, inclusive os contemporâneos ao escritor.

Na opção pelo suposto bem-escrito em detrimento dos conteúdos, eram os critérios formais - sintáticos e estilísticos - que norteavam as leituras e as análises, estas muitas vezes desdenhosas (por melhores e autênticas que fossem as intenções civilizadoras do escritor).

Os livros de Lima Barreto seriam reconsiderados mais tarde: mas, como se sabe, somente após decorrido o prazo de intervenção da crítica predominantemente formalista. Em seu tempo, o escritor demonstrava uma franca mágoa frente aos seus comentadores e alvejava os autores então mais divulgados e mais lidos - não por acaso, mais rebuscados na forma, praticamente inócuos no que diz respeito ao conteúdo de seus livros, só ficção.

Se um Coelho Neto, um de seus principais alvos, especializava-se em melhor tornear do que escrever em seus livros, Lima Barreto irradiava certo saudosismo pela época do Império, claro que a partir da voz dada a suas personagens. Carmen Lúcia Figueiredo apontou algumas dentre as prováveis causas para o descompasso entre o escritor e a República, que repudiava:

"Nos primeiros anos da República, evidenciam-se mundos de valores distintos na contradição entre as mentalidades e a elaboração do sonho republicano. De um lado, o mundo dos valores e idéias dos intelectuais, em pleno processo de desilusão com o novo regime; do outro, as classes pobres, que nunca haviam sido tocadas pelas promessas dos republicanos. Para o grosso da população, o ideal republicano traduziu-se em atitudes repressoras, como prisões, deportações, destruição de cortiços e favelas, para atender aos apelos do progresso e da ciência.” (p. 28) ${ }^{259}$

O fato é que a todo momento opiniões pessoais do homem Lima Barreto parecem migrar para a sua ficção e vice-versa: dado que levou a crítica a procurar sistematicamente em sua obra, inclusive com apoio da considerada não-ficcional, registros de suas idéias, de modo a aclarar a maneira como pensam e os meios pelos quais agem, ou principalmente reagem, seus protagonistas. Segundo Anoar Aiex:

"Lima Barreto considera os políticos do Império superiores aos da República. No Império, os políticos não visavam aos cargos públicos ou às funções governamentais, apenas pelos seus benefícios econômicos, eram também atraídos pela manutenção de tradições familiares ou simplesmente pela 'glória' ligada a determinado cargo. Ao passo que os políticos da República, corrompidos pelo dinheiro e pelo poder, encaravam os cargos públicos como meios para se beneficiarem mais depressa e com mais facilidade, ao mesmo tempo não agiam livremente, ou não podiam fazê-lo, pois seus interesses estavam ligados aos da burguesia.” (p. 26) ${ }^{260}$

\footnotetext{
${ }^{259}$ Lima Barreto e o fim do sonho republicano.

${ }^{260}$ As idéias sócio-literárias de Lima Barreto.
} 
Do regime de governo para os ambientes de trabalho, notadamente a imprensa, uma série de compadrios ${ }^{261}$ é que faria subir ou descer determinados nomes e obras. A esse respeito, o fato de Lima Barreto ter colaborado a maior parte das vezes em jornais de pequeno e médio porte seria revelado pelo gosto da personagem Gonzaga de Sá pelos periódicos menos conhecidos do público.

${ }^{261}$ Carmen Figueiredo observou que: “À medida que se comercializa, a partir do século XIX, a imprensa se torna manipulável, pois se estabelece a correlação entre a venda da parte de anúncios e a venda da parte redacional. (...) Esses procedimentos davam ao jornal o caráter de uma empresa de economia privada destinada a obter lucros.” (Op. Cit., p. 29) 


\section{Bastidores}

Os bruzundangas: "Só querem a aparência das coisas. Quando (em geral) vão estudar medicina, não é a medicina que eles pretendem exercer, não é curar, não é ser um grande médico, é ser doutor; quando se fazem oficiais do exército ou da marinha, não é exercer as obrigações atinentes a tais profissões, tanto assim que fogem de executar o que é próprio a elas. Vão ser uma outra coisa, pelo brilho do uniforme.” (p. 24) ${ }^{262}$

Os caminhos e atalhos para o poder convertem-se em expedientes narrativos que desmistificam a própria fatura literária, levando muitas vezes o leitor a refazer seu percurso como receptor, ao modo de um transgressor.

Traço que os distingue na ficção brasileira, Almeida, Machado e Lima Barreto manipularam nosso bovarismo sem piedade, sabedores do grau de artificialismo a que se submetia por conta própria uma nação composta por uma enorme margem de analfabetos. Segundo Lúcia Miguel Pereira:

"Vestindo, comendo, morando e pensando à européia, não tardaram os brasileiros a se iludir sobre si mesmos, a se acreditar em tudo e por tudo um povo mediterrâneo, transplantado para a América. Um povo velho habitando uma pátria nova. Esse estado de espírito talvez explique em parte a rápida assimilação do romantismo, que é, em última análise, o predomínio dos valores subjetivos. (...) o bovarismo, se foi típico do Império, com ele não morreu de todo, embora já antes do fim deste começasse a declinar. É esta uma das dificuldades da história literária, e certamente de qualquer história: as tendências não cessam repentinamente, não têm limites marcados, antes se prolongam e quase se confundem. (...) Ao bovarismo da era imperial ia sucedendo o cosmopolitismo da era republicana que, nas letras, começou mais ou menos na década de oitenta.” (pp. 21-2) ${ }^{263}$

A vigência do pro forma seria ou ainda é um sintoma do comportamento escapadiço do brasileiro? ${ }^{264}$ A malandragem de que fala Antonio Candido constitui matriz ou reflexo das práticas mal definidas, rotuladas por aqui ainda sob o generoso rótulo de espírito conciliador? ${ }^{265}$ De qualquer forma, como percebeu Carmen

\footnotetext{
262 Lima Barreto. Os Bruzundangas.

${ }^{263}$ Prosa de ficção.

${ }^{264}$ Segundo Dante Moreira Leite: "parece evidente a impossibilidade de falar em caráter nacional. De fato, se a classe alta brasileira tem maior afinidade com as classes correspondentes de vários países contemporâneos do que com a classe operária brasileira, parece difícil falar em caráter nacional que englobe as várias classes sociais brasileiras. Vale dizer, se não se pode, a rigor, falar em cultura brasileira, seria muito difícil imaginar o estabelecimento de uma relação entre essa suposta cultura e a personalidade modal do brasileiro." (O caráter nacional brasileiro, p. 127). Recentemente, Bosi alertava que: "Para nós, brasileiros, tão acostumados com as teorias do caráter nacional, e que ainda repetimos, às vezes automaticamente as definições prestigiosas que dele fizeram Gilberto Freyre e Sérgio Buarque de Holanda, acreditando que ambos tenham descoberto peculiaridades nossas, e apenas nossas, não deixam de impressionar as descrições que Gustave Lanson fez dos traços do caráter francês: 'a falta de paciência e de tenacidade, o inopinado e a mobilidade das resoluções, o amor da novidade, um certo senso prático e a disposição de se meter nos negócios dos outros por amor à justiça, o gosto da aparência e da ostentação, o da palavra e da eloqüência, tudo isto é francês e, se quiserem, tanto quanto inglês'.” (Literatura $e$ resistência, p. 8).
} 
Figueiredo, é o “jeitinho” que aproxima a ficção de Manuel Antônio de Almeida da obra de Lima Barreto:

“a concretização (...) [da] prática do arranjo pode ser percebida entre os muitos personagens de Triste fim de Policarpo Quaresma, doutores que não estudam, sábios ignorantes, almirantes sem navios, generais sem guerra, líderes apáticos, etc, cujas contradições se tornam nítidas pela manifestação do riso. O espocar dos risos sob controle na construção romântica, concretiza-se nas esquinas, ruas e becos onde vivem os personagens nada estáticos de Memórias de um Sargento de Milícias, de Manuel Antônio de Almeida. Movimentando-se entre o poder absoluto e a escravidão, esses personagens sobrevivem com saídas criativas, (o 'arranjei-me', o 'jeito') ao reproduzir, no seu dia-a-dia o comportamento da elite: a combinação esdrúxula de partes díspares num mesmo conjunto. Em outras palavras, dançam (reproduzem) a seu modo o minuete da corte. Assim, enquanto dançam não apenas parodiam a matriz, mas sugerem que a tal corte é também um conjunto esdrúxulo, anedótico, porque destoante, 'enviesado'.” (pp. 35$6)^{266}$

Talvez por sua tão relativa independência e maturidade, o Brasil ainda continuasse preocupado, até meados do século XX, em retratar a si mesmo, ora positiva ora negativamente. Nas palavras de Márcia Naxara:

"A principal característica que se encontrou para o brasileiro foi justamente a descaracterização: a ausência como traço fundamental. Daí a nação por formar-se; a nação por vir-a-ser. O Brasil e o brasileiro, retomemos, ocuparam um lugar privilegiado no cenário e no pensamento na virada do século XIX para o XX. Não apenas de um ponto de vista estritamente apegado à formação do mercado de trabalho mas, e principalmente, como ponto central da procura de uma identidade nacional. Uma identidade que vinha sendo construída no decorrer do século XIX e que foi tomando forma em múltiplas representações que, freqüentemente, contribuíram para a ambigüidade no tratamento da questão. Ambigüidade proveniente ora do descompasso entre o arcabouço teórico a partir do qual se pensou o nacional e a realidade com que se deparou, ora das discrepâncias entre os diferentes tipos sociais e as variadas formas com que se olhou para essa gente. Um olhar posto no futuro, que encontrou um presente, que se assemelhava ao passado" (p. 75) ${ }^{267}$

\section{Luiz Felipe Alencastro demonstrou a relevância da preocupação entre os}

brasileiros e portugueses, em meados do século XIX, com a configuração de sua imagem, fosse na rua ou no ambiente doméstico:

"Horas e minutos da regularidade diurna dos trópicos, cuja medida costumava parecer aleatória e desnecessária aos luso-brasileiros, começaram a poder ser marcados passo a passo, de cebolão na mão, nas casas, nas fazendas, nas estradas, nos rios, nos portos do litoral. Com a inauguração, a partir de 1850, de uma linha regular de navio a vapor entre Liverpool, na Inglaterra, e o Rio de Janeiro, o tempo imperial entra em sincronia com o tempo da modernidade européia." (p. 38) "De alto valor agregado e de imediato efeito ostentatório - as duas características que fazem desde então a felicidade respectiva dos importadores e dos consumidores brasileiros de renda concentrada -, o piano apresentava-se como o objeto de desejo dos lares patriarcais. Comprando um piano, as famílias introduziam um móvel aristocrático no meio de um mobiliário doméstico incaracterístico e inauguravam - no sobrado urbano ou nas sedes das fazendas - o salão: um espaço privado de sociabilidade que tornará visível, para observadores selecionados, a representação da vida familiar.” (p. 47)

\footnotetext{
${ }^{265}$ O mesmo Dante Moreira Leite afirma que somente no início dos anos 50 o país deixou a pretensão de buscar seu caráter de lado. Aparentemente, a literatura acompanhou a marcha. O próprio enredo de Macunaíma prenunciou o descrédito do conceito que tentava definir nosso caráter.

${ }^{266}$ Trincheiras do sonho - ficção e cultura em Lima Barreto.

${ }^{267}$ Estrangeiro em sua própria terra - representações do brasileiro: 1870/1920.
} 
Ora, Almeida, Machado e Lima criaram diversas figuras que bem ilustram a demasiada preocupação de determinados seres com a opinião alheia. Aqui se incluem aquelas que de tanto se ocupar dos outros aproveitavam o ensejo para lhes roubar o crédito, responder pela autoria de idéias supostamente originais ou frases lapidares. $\mathrm{O}$ problema é sério e espelha outro velho hábito nacional. Roberto Schwarz retomou a questão, associando-a à descontinuidade histórico-cultural característica que preside o discurso dos homens que se destacam na intelectualidade brasileira:

“Tem sido observado que a cada geração a vida intelectual no Brasil parece recomeçar do zero. $\mathrm{O}$ apetite pela produção recente dos países avançados muitas vezes tem como avesso o desinteresse pelo trabalho da geração anterior, e a conseqüente descontinuidade da reflexão. Conforme notava Machado de Assis em 1879, 'o influxo externo é que determina a direção do movimento’ (A nova geração). (...) Percepções e teses notáveis a respeito da cultura do país são decapitadas periodicamente, e problemas a muito custo identificados e assumidos ficam sem o desdobramento que lhes poderia corresponder.” (pp. 30-1) ${ }^{268}$

Os comportamentos de algumas personagens, bem como a transcrição de seus documentos (elogios à mesa, discussões, discursos e requerimentos) foram sistematicamente tratados de forma zombeteira. Nesses casos, a representação da linguagem comportada, “oficialesca”, vem quase sempre acompanhada da sátira político-social.

A Manuel Antônio de Almeida e Machado de Assis é aplicável a consideração de Carmen Figueiredo a respeito da estereotipia, esta semeada na obra de Lima Barreto: "Por que a caricatura? Justamente pelo objetivo que a constitui, isto é, o de apreender o característico. Com isso, torna-se num meio eficaz à revelação dos fetiches do cotidiano cujo conteúdo possui um sentido violento, absurdo e grotesco. Em outras palavras, o sentimento de frustração, que pairou sobre a Primeira República, não poderia admitir o formalismo e o lugarcomum na Literatura, nem tampouco o fantasioso.” (p. 114) 269 $^{26}$

Não é por acaso que tais escritores criaram figuras de extração social mediana. A classe média - camada essencialmente matizada -, comporta sem forma fixa, teorias e ideologias antagônicas que bem poderiam ser refletidas no caminho do avesso com que Leonardo-filho chega ao posto de sentinela, Porfírio, ao poder político e Gonzaga compensa sua sincera desmotivação no serviço público.

Assim como Manuel Antônio de Almeida e Machado de Assis, Lima Barreto não fixou datas exatas. Preocuparam-lhe certos episódios de nossa história, principalmente os de natureza política. Interessava tratar do cotidiano: manobra que, em seu caso, concedeu à ficção um maior tom de agressividade que na de seus antecessores.

\footnotetext{
${ }^{268}$ Que horas são?

${ }^{269}$ Lima Barreto e o fim do sonho republicano.
} 
Se nas Memórias de um sargento de milícias existe um protagonista cujas ações correm ao sabor do vento, contracenando com vários “comparsas”, em O Alienista, praticamente todos são antagonistas de Bacamarte. Já em Vida e morte de M. J. Gonzaga de Sá, a coexistência de dois protagonistas talvez tivesse por objetivo contagiar o leitor, convidando-o a atuar como terceiro convidado para compartilhar a visão de Augusto Machado e Gonzaga de Sá.

Reconhecido por questionar a falta de solidariedade em seu tempo, com a manobra Lima talvez visasse a uma franca interação - não somente artística, como também se vê nos dois escritores predecessores - entre narrador e leitor.

As personagens de extração mediana, desenhadas por Manuel Antônio de Almeida, Machado de Assis e Lima Barreto não levam a vida estável dos típicos heróis romanescos românticos ou realistas. O compadre barbeiro e a comadre parteira (Memórias de um Sargento de milícias), os barbeiros (O Alienista) e os funcionários públicos (Vida e morte de M. J. Gonzaga de Sá) representam, ainda que de forma caricata, a escorregadia classe intermediária. ${ }^{270}$

Trata-se de histórias de homens que fogem às regras, como Leonardo-filho; que as promovem, a exemplo de Bacamarte, ou que a elas se conformam, vegetando no emprego público, como Gonzaga de Sá.

Homens de ofertas vazias ou sem alcance, mas cheios de idéias fixas, como os machadianos Brás Cubas (o fetiche do emplasto) e Rubião (o fetiche por Sofia). O primeiro, com a pretensão de se tornar famoso; o segundo, convencido do êxito contido na fórmula beleza e amor por dinheiro: falsa sabedoria, sabedoria de Sofia. ${ }^{271}$

O tom mais incisivo de Lima Barreto talvez denunciasse o pedantismo geral de homens ocos; mas apontava também alguns dos sintomas da dupla frustração dele mesmo: o abandono dos estudos de engenharia e o cargo mediano na longa carreira pública.

\footnotetext{
${ }^{270}$ Para Darcy Ribeiro: “As classes intermediárias demonstram seu 'caráter ambíguo', apesar de em oposição às 'dominantes', no papel de perpetuadores da ordenação social que as privilegia; as dominadas, à condição histórica de força virtualmente insurgentes. Situado entre essas grandes classes antagônicas, o estrato intermediário opera como atenuador ou agravador das tensões sociais e é levado a exercer, ora o papel de agente da manutenção da ordem instituída, ora o de ativista de suas alterações revolucionárias. Não é propriamente uma classe, mas um conglomerado ocupacional cujos interesses não estão necessariamente em causa face à oposição principal. Seus membros podem, por isto, pender para uma ou outra posição em cada conflito concreto e até assumir as posições mais radicais” (Os brasileiros: teoria do Brasil, p. 92).

271 “Ce que la raideur de l' idée fixe est à l'esprit, certains vices ne le seraient-ils pas au caractere?” (Le rire, p. 11). * “O que o rigor da idéia fixa é para o espírito, certos vícios não seriam para o caráter?”
} 
É possível que as motivações artísticas estivessem associadas ao seu mal disfarçado complexo de inferioridade socioeconômica, principalmente em razão de sua etnia e condição financeira. As descrições sobre o comportamento surreal dos "bruzundangas” antecipariam estas notas de Sérgio Buarque de Holanda:

"no vício do bacharelismo ostenta-se também nossa tendência para exaltar acima tudo a personalidade individual como valor próprio, superior às contingências. A dignidade e importância que confere o título de doutor permitem ao indivíduo atravessar a existência com discreta compostura e, em alguns casos, podem libertá-lo da necessidade de uma caça incessante aos bens materiais, que subjuga e humilha a personalidade. (...) a origem da sedução exercida pelas carreiras liberais vincula-se estreitamente ao nosso apego quase exclusivo aos valores da personalidade. (...) Não é outro, aliás, o motivo da ânsia pelos meios de vida definitivos, que dão segurança e estabilidade, exigindo, ao mesmo tempo, um mínimo de esforço pessoal, de aplicação e sujeição da personalidade, como sucede tão freqüentemente com certos empregos públicos.” (p. 157)

Para romper com os protocolos sociais que testemunhavam em suas épocas, os criadores também deram luz a esposas, amantes, filhas, mães e irmãs, cuja existência funciona nos episódios aqui comentados como pilar: ponto de relativização frente às polêmicas decisões dos líderes masculinos.

Luizinha, a prendada sobrinha de D. Maria, contrariando as expectativas romanescas do período, não obedecerá ao protocolo da mulher que se entrega por amor e dote. Na verdade, casa-se com José Manuel e só se vai unir a Leonardo-filho por ter perdido o marido que não amava. Mesmo seu segundo casamento só se efetiva quando Leonardo-filho é favorecido pelo até então inimigo, o ordeiro absoluto major Vidigal.

A Simão Bacamarte, o inflexível cientista dono de Itaguaí, coube Evarista, mulher submissa, frívola e de pouco brio, exceto quando diante da engenhosa tarefa de optar entre um colar e outro. A patologia da Eva infértil reside em sua postura afetada de provinciana com fumos de nobre, certamente contagiada pela posição em que o marido fora investido.

Escolástica, a tia de Gonzaga de Sá, permite entender a postura e os comportamentos do sobrinho. Mulher de modos tranqüilos e emocionalmente equilibrada, seu nome evoca uma linha de pensamento que, do ponto de vista filosófico, pode-se denominar escolar, racional: dialética. ${ }^{273} \mathrm{E}$ não é dialeticamente que se dão as conversas entre Gonzaga e Augusto?

A personagem aparece no romance justamente quando seu sobrinho, Gonzaga, recebe o amigo Augusto em casa. No papel de narrador-testemunha, Augusto registra a

\footnotetext{
${ }^{272}$ Raízes do Brasil.

${ }^{273}$ Atlas de la philosophie, p. 65.
} 
aparência de Escolástica - "linda figura de velha”, ressaltada a "candura” (p. 50) - e a lógica que preside o diálogo estabelecido entre tia e sobrinho.

\section{III}

Nas três obras, o que diz respeito ao aspecto exterior (roupas e habitações) é salientado justamente para, entre outras coisas, derrubar pretensas convenções e posturas de classe, artificialmente remontadas no país. A moda, por aqui, é transplantar, imitar, ainda que com décadas de atraso, certos procedimentos das refinadas castas do mundo europeu - berço dos reinóis de pompa, no comando de Portugal e domínio sóciocultural do Brasil. ${ }^{274}$

De maneira similar àquela apresentada em Memórias de um sargento de milícias, o narrador de $O$ Alienista faz questão de referir, ainda que de forma pouco precisa, o momento histórico a que se refere. Nas Memórias, o recuo temporal fixa o ponto de partida do enredo e chama a atenção do leitor para alguns traços que remontam à nossa colonização.

Talvez tanto Manuel Antônio de Almeida quanto Machado de Assis e o próprio Lima Barreto necessitassem revelar o traço colonialista de nosso “espírito", explicitando-o através de personagens e matreiros narradores que ressaltassem detalhes de nossa postura teoricamente pacífica, em meio às práticas conciliatórias. Gente provinciana, subserviente e dependente, mas algo violenta, quando voltada para as antigas e ainda pendentes questões de classe e disputas pelo poder.

Além das características externas, tanto no romance de Almeida como na novela de Machado, a maioria das personagens recebe nomes incompletos ou epítetos, como a revelar a intimidade dos respectivos narradores com as histórias relatadas. Um narra com base no relato oral; outro, no documento (as crônicas da Vila). Em Vida e morte de Gonzaga de Sá, não é o que sucede: depoente e protagonista foram configurados para serem interpretados a sério.

Motivo de chacota ou recriminação sem disfarce, acima de tudo, a ordem $e$ a desordem; o poder $e$ seus abusos, por vezes associados à falta de um nome por inteiro, impossibilitando que se atribuíssem responsabilidades ou se assumissem as posturas que

\footnotetext{
${ }^{274}$ Segundo Renato Janine Ribeiro: “O que funda a qualidade de nobre é um estilo de vida desde que reconhecido por longo tempo. Nada, por sinal, mais barroco: o ser de um homem se confunde com sua aparência. Quem age como nobre é nobre. O problema, porém, é que pelas boas maneiras não é possível discernir com precisão os graus da sociedade: elas marcam apenas uma ruptura, entre o refinamento e a rudeza. Além disso, como são fáceis de copiar, as fronteiras se apagam. Por isso é importante no Antigo Regime outra função da vida social - a moda.” (A etiqueta no Antigo Regime, p. 19)
} 
demonstrassem firmeza de caráter ou retidão de propósitos. Hélcion Ribeiro estudou o tema, ilustrando bem o conceito de cordialidade de Sérgio Buarque de Holanda:

"Nos relatos dos viajantes estrangeiros dos séculos passados, nos comentários atuais e, na verdade, na prática brasileira, a unidade básica é a pessoa e suas relações. O subjetivismo é algo maior e mais importante que as instituições. $E$ a fidelidade às pessoas supera todos os impasses entre ela e a lei, entre ela e a justiça. Tal relação só não vale para os inimigos, sobretudo se eles são de classes subalternas: é a lei cultural que afirma 'para os amigos tudo, para os inimigos a lei’. A unidade básica é a pessoa caracterizada pelo nome ou por apelidos (só raramente pejorativos) e não pelo sobrenome de família. O costume europeu de identificar pessoas pelo sobrenome não consegue se estabelecer entre nós porque Pedro é Pedro e não o Sr. Souza. Reconhecer pelo nome aproxima as pessoas e, inclusive, força uma democratização social, que aproxima a autoridade e o súdito. Se entre ambos há a inicial distância respeitosa, logo passa a haver um respeito cordial. Se entre ambos há a inicial distância respeitosa, logo passa a haver um respeito cordial. A intimidade com a autoridade e com a lei reestrutura as relações entre a pessoa e a família, entre a família e os grupos de parentesco e amizade. Este elemento, afora a timidez individual, transforma espaços públicos e oficiais em familiares, onde o jeito (que pode até ser gorjeta) logo se instala, criando uma relação de favor e dependência.” (pp. 78-9) 275 $^{275}$

Alguns protocolos do poder receberam tratamentos diversos. Enquanto Machado de Assis desnudava-os em ricas e complexas tramas, envolvendo interesses e ingenuidades de forma sutil - alfinetando com algodão determinados profissionais ou desocupados -, o menos diplomático Lima Barreto levava seus personagens a falar dos vícios percebidos no país, bem como das polêmicas correntes de pensamento que aqui criaram herdeiros altivos e orgulhosos por nada e contra tudo aquilo que lhes representasse perda de controle (sobre o quê?) ou o poder de nada fazer. ${ }^{276}$

\section{IV}

A sátira e a ironia podem servir à literatura e fazer-nos leitores-reféns de um prazer que não cura. Machado dedicou vários escritos à descrição de bons maus modos. Há oradores de beira de mesa (As bodas de Luís Duarte); discursadores falaciosos ( $O$ Alienista); namoradeiras casadas (Virgília); enrustidas (Sofia); boas-vidas (Brás Cubas);

\footnotetext{
${ }^{275}$ A identidade do brasileiro. Nestor Duarte atestou a raiz histórica do privatismo no Brasil: "Tanto quanto a luta do costume contra a lei, do hábito contra o novo, essa ordem privada é a velha rodem formando um mundo moral e um mundo sentimental, com outro sentido humano para viver e resistir contra a outra ordem, mais seca, sem riqueza emocional e tão mais perigosamente abstrata, como é a do Estado em si mesmo.” (Op. Cit., p. 112). Roberto DaMatta afirmava que: "No caso brasileiro (...) não deveria causar surpresa ou polêmica o fato de que o povo que faz o carnaval ser precisamente o povo de Sete de Setembro; o chefe ‘boa-praça' ser o homem do ‘sabe com quem está falando?’; o homem cordial ser capaz de violência; e o malandro e o caxias serem igualmente admirados.” (Op. Cit., p. 67)

${ }^{276}$ Da ficção para a vida: ironia cruel, o nome Lima Barreto foi explorado comercialmente tão logo faleceu o escritor, como comprova o registro de Francisco de Assis Barbosa: "Estas crônicas sobre a República das Bruzundangas começaram a aparecer em janeiro de 1917 no semanário ABC, dirigido por Paulo Hasslocher e Luís Moraes, onde se encerra boa parte da colaboração de Lima Barreto na imprensa. (...) O prefácio de Bruzundangas (é importante lembrar) é datado de 2-9-1917. O editor, porém, esqueceu o livro. E só lembrou de publicá-lo depois da morte de Lima Barreto, anunciando-o com espalhafato (...) Era um truque de publicidade. Morto em novembro, Lima Barreto não tivera tempo nem sequer de ler as provas (...) livro que contém os piores erros de revisão. A atitude do livreiro Jacinto provocou, por isso mesmo, protestos na imprensa, como o de Raimundo Magalhães, n’A Tribuna, de 12-12-1922. (“Explicação necessária” In: Lima Barreto. Bruzundangas, pp. 5-6).
} 
negociantes (Palha, Camacho)... E tudo - do flerte ao grande negócio - principia ou se resume na habilidade em se comportar na mesa ou no palanque, ao discursar, no vestir.

O que o romance-anedotário de Manuel Antônio de Almeida intuíra, Machado refinara e Barreto explorava sem meias palavras ${ }^{277}$ : assim, é o tom de negligência geral que se percebe nas ações de algumas personagens das Memórias de um sargento de milícias; da peripécia, entre os habitantes de Itaguaí, e da gravidade sem maiores efeitos práticos - ao menos, nos domínios da ficção - no romance de Lima Barreto.

A ação predomina no romance de Almeida; os acontecimentos norteiam a novela de Machado; já a construção do pensamento das personagens ${ }^{278}$ parece ser a razão de ser do romance de Lima. Na própria indistinção entre os gêneros ${ }^{279}$ de que se servem os escritores (romance-folhetim, conto-novela e romance-novela) parece haver uma pista do caráter escapadiço, mais que maleável, das figuras e de seu nicho social. Figuras que, vez ou outra, não parecem tão afastadas daqueles seres emblemáticos, encontráveis no mundo de verdade. Da imitação à afetação um pequeno passo.

Os indícios de novas posturas de país novo, refletidos por seus jovens habitantes, demonstram o desconforto frente à necessidade de aparentar o que não se é. Nicolau Sevcenko percebe a passagem do Império para a República (tempo em que sucede o encontro de Gonzaga de Sá ${ }^{280}$ e seu admirador, Augusto Machado) como a investidura de novos costumes fora de hora ou prazo, utilizados por aqui:

“(...) acompanhar o progresso significava somente uma coisa: alinhar-se com os padrões e o ritmo de desdobramento da economia européia. (...) O novo cenário suntuoso e grandiloqüente exigia novos figurinos. Daí a campanha da imprensa, vitoriosa em pouco tempo, para a condenação do mestre-de-obras, elemento popular e responsável praticamente por praticamente toda edificação urbana até aquele momento, que foi defrontado e vencido por novos arquitetos de formação acadêmica. (...) Também com relação à vestimenta verifica-se a passagem da tradicional sobrecasaca e cartola, ambos pretos, símbolos da austeridade da sociedade patriarcal e aristocrática do Império, para a moda mais leve e democrática do paletó de casemira clara e

\footnotetext{
${ }^{277}$ Segundo Cavalcanti Proença, Lima Barreto "Não só nas citações, mas, ao narrar um fato, ao expor uma idéia, aos transmitir uma informação de leitura, timbra em ser preciso, fiel, honesto.” (p. 35)

${ }^{278}$ Cf. a classificação quanto às obras “de espaço”, “de acontecimento" e "de personagem”, proposta por Wolfang Kayser. "O romance de personagem diferencia-se estruturalmente do romance de ação já pela figura principal única, enquanto que no outro caso é o uso serem duas” (Op. Cit., p. 265). Conforme Georg Lukács: "o que nos interessa é ver como [as personagens] reagem diante dos grandes acontecimentos de suas vidas, como enfrentam os perigos, como superam os obstáculos, e como os traços que tornam interessantes e significativas as suas personalidades se desenvolvem sempre mais ampla e profundamente na ação.” (Ensaios sobre literatura, p. 58)

${ }^{279}$ Segundo Raul Castagnino: "A partir do século XVIII - sobretudo com o aparecimento do periodismo vai-se registrando um aumento de camadas sociais em condições de abordar diretamente a obra literária impressa. Aparecem, como conseqüência, certas formas literárias 'especializadas', convenientes a determinados setores da sociedade. (...) Significa isto, também, a especialização dos receptores.” (Análise literária, pp. 71-2)

${ }^{280}$ Não custa lembrar que Gonzaga de Sá é um saudosista admirador do Império e, como tal, veste-se de casaco e sobrecasaca - ambos pretos.
} 
chapéu de palha. O importante agora é ser chic ou smart conforme a procedência do tecido ou do modelo.” (pp. 28-31) 281

Nelson Werneck Sodré, concentrado nos aspectos histórico-econômicos refletidos nos hábitos sociais urbanos a partir de meados do século XIX, havia mencionado a predisposição cultural dos brasileiros para a veloz e, por isso, canhestra assimilação de modismos e moldes alheios:

"Técnicas novas faziam o seu aparecimento no quadro brasileiro: técnicas de transporte, com as ferrovias; técnicas de comunicações, com o telégrafo. Aparelhavam-se os portos, difundia-se a imprensa, que perdia a característica de transitoriedade para surgirem os primeiros jornais de vida permanente, crescia o interesse por diversões urbanas, do tipo do teatro, a rua começava a ter um papel na vida social, e uma sociedade velha, que alterava rapidamente os seus padrões, começava a provar os salões, a interessar-se pelas modas, a conviver, a aparentar e a influir. A classe dominante, que realizara a autonomia e lhe dera a sua marca, sente-se na necessidade de exercer o poder público e para isso se adestra, nas academias, no parlamento, na imprensa, na vida política, no convívio dos salões.” (p. 341) ${ }^{282}$

Quatro décadas após a publicação de O Alienista, Mário de Andrade deslocaria o eixo de representação: em Macunaíma não é sobre a personagem/anti-herói que recaem os caracteres; mas sim, nos expedientes percebidos em sua trajetória, incluindo a carta destinada às Amazonas. O episódio não só diverte pela conjunção entre formalidade e subversão de valores, mas também por estabelecer uma sofrível ponte entre a maior metrópole brasileira e os longínquos confins do país.

Tal conjunção cultural parece clamar sub-repticiamente pela valorização do elemento nacional, ainda mais descaracterizado com o advento da acelerada urbanização e afetação de modos entre os habitantes de São Paulo - a exemplo do que já ocorrera no Rio de Janeiro, nas épocas de Manuel Antônio de Almeida, Machado de Assis e Lima Barreto. A ostentação tem e faz história. Luiz Felipe Alencastro observa que:

"Cessado o tráfico, ocorre um retorno das divisas obtidas nas vendas de produtos de exportação e até então reservadas para financiar a compra de africanos. O efeito na balança comercial e na balança de pagamentos do Império é imediato. Comparando-se o qüinqüênio de 1845-50 ao de 1850-5, constata-se que o valor das importações do Rio de Janeiro cresce uma vez e meia. (...) Cavalos ingleses e de raça árabe, próprios para passeios, foram importados da Inglaterra. (...) No item relativo a jóias e objetos de ouro e prata, o crescimento é de quase três vezes. Os artigos classificados como não especificados - nos quais devem estar incluídos pianos e toda sorte de novas mercadorias de consumo - tomam proporções consideráveis na pauta de importações. De um qüinqüênio ao outro (...) sete vezes.” (p. 37)

\footnotetext{
${ }^{281}$ Literatura como missão - ilusões sociais e criação cultural na I República.

${ }^{282}$ História da Literatura Brasileira.

283 “Vida privada e ordem privada no Império” In: Fernando A. Novais (coord.) História da vida privada no Brasil: Império [Vol. 2].
} 
A publicação do romance de Mário de Andrade não parece totalmente desvinculada do quadro de questionáveis avanços e recuos, sob a égide dos militares, mal disfarçada na virada do século XIX para o XX. Nos termos de Werneck Sodré:

"A influência do positivismo nos meios militares, na época, tão condizente com o moralismo e demais posições éticas peculiares à pequena burguesia, assinala (...) a possibilidade de adoção de impulsos renovadores sem rompimento com os valores tradicionais. (...) As tentativas de industrialização eram tolhidas por todas as formas. Ficava estabelecida a doutrina a que todos deveriam obediência. Seu formulador fora o próprio presidente da República: 'É tempo de tomar o caminho certo; o que nós devemos fazer para esse fim é nos esforçarmos para exportar tudo quanto pudermos produzir em melhores condições do que outros países, e importar tudo quanto eles possam produzir em melhores condições do que nós' (Campos Sales, em 3 de março de 1899). Era a própria teoria da estagnação, consagrada como lei, e fora da qual não havia saída.” (pp. 8-11)

\section{$\mathbf{V}$}

Documentos, carimbos e chancelas, discursos e demais protocolos vinculam de forma tênue pessoas que fazem uso da aparentemente segura linguagem pré-construída. É aí que entra o elemento cômico, chamando atenção para o que há de sério na escrita. É que o riso quebra sem aviso. Rompe o intervalo entre o exercício da escritura (da anedota ao panfleto) e a sensaboria do contexto burocrático vivenciado por seus autores: suspensão sob forma de arte.

A inovação assusta. Às vezes, determinadas atitudes corajosas soam como sintomas de negligência. Escritores e obras são alvos de críticas inflexíveis - a exemplo do aconteceu com Almeida e Lima, este defendido por Pereira da Silva:

"O fato é que o descobridor de A República dos Estados Unidos dos Bruzundangas seria açoitado como um escravo rebelde. Veriam desleixo onde há proposital forma de não parecer parente do pesadão Alexandre Herculano, ou por procuração, ainda menos válida, de Corneille, sem levar em conta os alemães.” (p. 58)

\section{Tablados e protagonistas}

“Quem tem ambições deve andar bem informado” (Saint-Simon)

As trajetórias de Leonardo-filho, Simão Bacamarte e Gonzaga de Sá revelam traços comuns à fatura das histórias que protagonizam. O fato de se tratar de historietas ambientadas na cidade parece ajustado a composições que enfatizam figuras cujos ofícios estão ligados ao domínio social urbano.

Todos vivem nas ruas. Daí as arruaças de Leonardo-filho em meio aos demais habitantes, os passeios de Bacamarte com os alienados ao ar livre e as reflexões solitárias de Gonzaga à beira-mar.

\footnotetext{
${ }^{284}$ Literatura e história no Brasil contemporâneo.

${ }^{285}$ Lima Barreto - escritor maldto.
} 
Seus descaminhos aproximam tais ficções do gênero biográfico. Mas por que os protagonistas não enunciam sua própria trajetória? Porque os autores pretendiam colocar em evidência não um discurso explicitamente dramático ou confessional. Porque, embora protagonistas, Leonardo-filho, Simão e Gonzaga devem funcionar como objetos de seus respectivos narradores: dois anônimos e Augusto, testemunha.

O paradoxo se evidencia. Leve-se em conta que é sobre os protagonistas sabichão, doutor e funcionário público - que giram as narrativas. O fato de os relatos serem registrados em terceira pessoa, no entanto, evidencia a presença de enunciadores que cumpririam o papel romanesco esperado por um público ávido por leitura: permitir alguma neutralidade na história que contam. Mas o distanciamento afetado pelos narradores sem nome das Milícias e de O Alienista é só aparente.

Uma das razões para Memórias de um Sargento de milícias e O Alienista terem sido escritos em terceira pessoa é que poderia ser mais brando abordar certas questões ligadas aos vícios nacionais mais perversos sob o abrigo da voz indireta do narrador. Para tais narradores, portanto, é uma situação relativamente mais confortável, aceitando-se que levassem em conta a recepção dos leitores.

A manobra permite o cultivo mais livre do dado estético, já que os assuntos a serem levados a sério teriam sido devidamente amainados pela anedota, restando ainda espaço para o exercício da forma. Terceira voz: misto de biografia (vozes) e crônica (feitos).

As três biografias (de Leonardo-filho, Simão Bacamarte e Gonzaga de Sá) compõem-se de registros na forma de crônica, sob o enfoque da autoridade policial e política, respectivamente no caso de Almeida e Machado; da burocracia, mais nítida na abordagem de Lima Barreto. Em seu caso, aliás, aplicam-se as considerações de Bakhtin:

"Um acontecimento estético pode realizar-se apenas na presença de dois participantes, pressupõe duas consciências que não coincidem. Quando a personagem e o autor coincidem ou estão lado a lado diante de um valor comum ou frente a frente como inimigos, termina 0 acontecimento estético e começa o acontecimento ético que o substitui (o panfleto, o manifesto, o discurso acusatório, o discurso laudatório e de agradecimento, o insulto, a confissão-relatório etc).” (p. 20) ${ }^{286}$

Os narradores nos colocam à meia distância dos biografados. Dois deles fingem relatar de longe suas diabruras (Leonardo) e teorizações (Bacamarte). Outro registra os protestos (Gonzaga) com os quais alimenta seus próprios questionamentos. Volta e meia inserem elementos da vida particular dos protagonistas e, nesse sentido, se a rua e os

\footnotetext{
${ }^{286}$ Estética da criação verbal.
} 
espaços públicos servem de tablado para as estripulias e reflexões do malandro, do louco e do sábio, o ambiente doméstico favorece o contraponto, a suspensão das ações. Em lugar de expansão, introspecção. Não é por acaso que Simão Bacamarte e Gonzaga de Sá só apareçam lendo quando em casa, distantes da rua, ambiente em que o mascaramento se faz mais necessário.

Quanto à forma, em Almeida e Machado há o predomínio de trechos mais narrativos do que descritivos. No romance de Lima Barreto são os períodos dissertativos que vêm intercalados ou associados aos períodos descritivos.

\section{II}

Muitos dos temas presentes nas obras foram tratados sob o véu de uma hierarquia nem sempre evidente, que tais narrativas colocam sutilmente em questão, apelando para a comicidade ou a melancolia. É a hierarquia de um Rio de Janeiro no tempo de el-rei que Leonardo-filho desbanca e na qual Bacamarte toma o principal assento. É a hierarquia burocratizada que Gonzaga questiona, ao longo de suas caminhadas compartilhadas com Augusto Machado.

Além do elemento biográfico, a proximidade com o registro do cotidiano. À crônica de costumes e dados históricos (Milícias) sucede a crônica política (O Alienista) e a abordagem que pondera a sério a burocracia e a afetação em sociedade (Gonzaga de Sá).

Os aspectos temporais também são diversos em cada um dos casos. Em Almeida, há um quê intencional de “passadismo" - embora o romance tenha a vivacidade do presente - relembrado a todo instante por expressões que remetem a outra época, o tempo de el-rei.

Leonardo-filho nasce, como ficou dito, por obra de um instante de volúpia de dois portugueses rumo ao Brasil, no tempo do rei. Sem lar fixo, pátria ou patrimônio, as peripécias do jovem parecem provocadas pela falta de pulso familiar e domicílio certo e a situação politicamente indefinida do próprio país de berço.

Sua vida social, se não obedece aos padrões da época, é absolutamente intensa, favorecida a todo instante pelas intermináveis festividades ligadas ao calendário cristão: tremenda ironia.

Desse modo, o malandro escorrega entre três instituições: a família que não tem (representada vicariamente pelos padrinhos), a lei que não segue (incorporada pelo major Vidigal) e a religião que só lhe serve como motivo para festejar e estabelecer 
relações com os demais traquinas. Malandro desfavorecido, sem dados de origem ou perspectiva. Como ser responsável sem identidade? ${ }^{287}$

Os três pilares rachados ilustram as falhas na manutenção dos poderes, no romance. E por estar envolvido com pessoas de diversas camadas, o círculo social de Leonardo-filho é relativamente amplo (do padrinho remediado a Maria, tia abastada de Luizinha). Pode ilustrar a ductilidade de sua personalidade e do próprio meio - também móvel porque dilui, em favor da personagem, a noção de limite entre os espaços públicos e privados. Nos termos de Roberto da Matta:

"Quando se trata de rejeitar o mundo, rejeita-se no Brasil o universo das relações pessoais para se cair de quatro no universo das leis impessoais, essas regras que esfolam e submetem todos os desprotegidos (ou seja, gente sem relações, gente indivisa). (...) aos bem relacionados, tudo; aos indivíduos, (os que não têm relações), a lei”. (p. 24) ${ }^{288}$

As posturas de Leonardo-filho ${ }^{289}$ desequilibram sem querer a ordem vigente e, em última instância, constituem manifestação - ainda que involuntária - contraposta à dominação absolutista. É que Leonardo, filho do meirinho (outro oficial da lei, na escala que segue até o rei), põe à prova o poder real, representado nos domínios da cidade pelo major Vidigal, braço da guarda real.

O destino de Leonardo-filho reserva-lhe, no entanto, a acomodação trazida pelo casamento com Luizinha e o posto de sargento, pré-requisito com as benesses do próprio Vidigal. Sem mais estripulias, o malandro consumado até a noite anterior, acaba assimilado à cidade colonial com ares de uma Paris aportuguesada em solo tropical.

O jovem está à beira da convenção, já que o matrimônio e o emprego público necessariamente reduzem as atividades em seu antigo meio social. Implica contar com posses decorrentes de dois compromissos com peso de instituição, fixidez, estabilidade

\footnotetext{
${ }^{287}$ Diz Alfredo Bosi: "aquela busca ansiosa e recorrente de auto-imagem que os intelectuais brasileiros, e não só brasileiros, realizaram no afã de responder à interrogação 'quem somos nós enquanto nacionalidade?’ não pode ser satisfeita nem pela sociologia, nem pela antropologia, nem pela psicologia, mas só por um 'saber' sob suspeita, entre emotivo e dogmático, que se chama ideologia.” (Céu, inferno, p. 268)

${ }^{288}$ Op. Cit.

289 De acordo com Antonio Candido, "Na formação histórica dos Estados Unidos houve desde cedo uma presença constritora da lei, religiosa e civil, que plasmou os grupos e os indivíduos, delimitando os comportamentos graças à força punitiva do castigo exterior e do sentimento interior de pecado. Daí uma sociedade moral. (...) Esse endurecimento do grupo e do indivíduo confere a ambos grande força de identidade e resistência; mas desumaniza as relações com os outros, sobretudo os indivíduos de outros grupos. (...) No Brasil, nunca os grupos ou os indivíduos encontraram efetivamente tais formas; nunca tiveram a obsessão da ordem senão como princípio abstrato, nem da liberdade senão como capricho. As formas espontâneas da sociabilidade atuaram com maior desafogo e por isso abrandaram os choques entre a norma e a conduta, tornando menos dramáticos os conflitos de consciência. (...) a sociedade brasileira se abriu com maior largueza à penetração dos grupos dominados ou estranhos. E ganhou em flexibilidade o que perdeu em inteireza e coerência.” (“Dialética da malandragem”, p. 43)
} 
inédita. Esposa e salário: patrimônios para um sucessor de ninguém, que nada herdara de seus pais. Nas palavras de Alfredo Bosi:

“A instituição é, afinal, o espaço histórico já delimitado onde se obrigam e se satisfazem as necessidades básicas dos grupos humanos. É, em todas as acepções do termo, o seu lugarcomum. O lugar-comum não precisa ser belo nem sublime, basta-lhe a utilidade, como ao papelmoeda.” (p. 81)

Na novela machadiana, o leitor é tentado a se perguntar o que teria sucedido, de fato, ao médico, desde seu confinamento na Casa Verde. Presente com saldo para o futuro.

Simão Bacamarte nasce no Brasil, forma-se em Pádua e Coimbra; faz-se protegido do rei e pelas mesmas mãos reais regressa à colônia para aplicar na longínqua e obscura Itaguaí os conhecimentos teóricos de medicina, as anotações da religião e os conceitos da filosofia árabe. Calhamaços para leituras de teor eminentemente hermético, bem ao gosto da vila escolhida e em acordo com o futuro do próprio médico: ilhado por loucos no abrigo da faraônica Casa Verde.

Os estudos sobre psiquiatria impossibilitam que faça um grande número de amigos ou aliados, o que se combina ironicamente à sua discreta austeridade de homem maduro, beirando os quarenta anos, casado e instalado na segunda maior residência da modesta vila.

Desde o regresso ao Brasil, portanto, Simão possui um "lar": território de grandes dimensões que não só imprime prestígio à sua imagem, como simboliza o desnível entre o líder e os demais provincianos. Itaguaí é, nesse sentido, um braço da recém instituída capital do país, ou seja, está ligada cultural e politicamente a Portugal, através do também provinciano Rio de Janeiro.

Três são os grupos sociais que habitam a vila: o clero (Lopes), os políticos e o médico (nobres) e os pequenos comerciantes (o albardeiro, os dois barbeiros e o boticário). Simão Bacamarte clinica sob um regime que se mostra ditatorial, aos olhos dos habitantes de Itaguaí. É, emprestando novamente a terminologia de Weber, um dominador carismático cuja grandeza vem reconhecida - ainda que sob certas contingências, pelos indivíduos da própria comunidade - com o franco suporte do absolutismo real.

Obstinado, o psiquiatra chega à premissa maior: percebe como outra a postura de si mesmo, o que coloca em questão a sua função naquela sociedade: versão em miniatura do universo, também só seu. A inutilidade das práticas do cientista, na vila,

\footnotetext{
${ }^{290}$ Machado de Assis: o enigma do olhar.
} 
permite questionar a validade do poderio concedido sem amarras pelo reino a um médico sem pacientes de fato.

Já na narrativa barretiana, o dado concreto marca as palavras de Gonzaga e o testemunho do narrador. Experimenta-se uma forte sensação de tempo presente. Não há maiores alusões ao pretérito ou ao amanhã, mesmo porque as personagens pouco fazem referência ao passado e menos acreditam no futuro.

Gonzaga de Sá é descendente de uma tradicional família de colonizadores de sua terra. Aos sessenta e poucos anos, divide a casa com a tia Escolástica e o "Café Papagaio”, com os amigos - basicamente, os colegas adquiridos ao longo de sua planificada vida na repartição pública.

Conservador no aspecto, sisudo e vestindo roupas sóbrias, revela no íntimo, convicções opostas ideologicamente à tradição aristocrática. Sua moradia é “funcional”291: serve para repousos, cafés e leituras. No romance não há menção à religião, e muito pouco o narrador poderá extrair sobre a vida afetiva do amigo. Restam a Augusto Machado os assuntos que despontam nas caminhadas, já que reforçam as teorias de Gonzaga bem como permite ao mais jovem tecer suas próprias críticas aos costumes dos conterrâneos.

Gonzaga era um homem lúcido, mas desiludido, sem o toque da ambição ou a força do otimismo. Embora estivesse relativamente acomodado à carreira pública, viveu a questionar o artificialismo que presidia as relações sociais na capital da recente República.

Contestador sem grandes feitos, suas contínuas caminhadas não só o levam a conhecer todos os cantos da cidade. Constituem um recurso para que ele "domine" o espaço que com ele cresceu, mas foi apropriado pelos homens inescrupulosos. O espaço público é por ele convertido em território particular. Privacidade que os pés reconhecem, desafiando ao mesmo tempo o progresso representado na velocidade dos bondes e das reformas sem maturação social ou política. Pés que registram com vagar em lugar de devorar o solo de piche.

\footnotetext{
${ }^{291}$ Conforme Norbert Elias: “As camadas sociais inferiores não têm necessidade de se 'representar', não têm deveres de classe. $\mathrm{O}$ aspecto das suas habitações é determinado por estruturas que não estão obrigatoriamente ausentes nas outras mas que, nestas, desaparecem sob os dispositivos de representação e de prestígio.” (Op. Cit, pp. 33-4).
} 


\section{Rubricas}

Almeida, Machado e Lima trabalham com personagens da cidade. Em Itaguaí ou no Rio de Janeiro, o que se vê são profissionais ligados a ocupações de baixo e médio escalão. É no ambiente urbano que acontecem as negociatas entre as famílias, a contenda judicial, o aporte das incontáveis festas públicas, explorados nas Memórias.

Na novela de Machado, o provincianismo converte-se em um dos sintomas diagnosticados pelo alienista: ser louco é ser medíocre. Eu, Bacamarte, sou nobre e instruído: logo serei recluso para isolar não a mim, mas o resto. Nas palavras de Rotterdam:

"Tudo quanto os homens fazem está cheio de loucuras. São loucos tratando com loucos. Conseguintemente, se existir sequer uma cabeça que deseje impedir a torrente da multidão, apenas um conselho posso dar-lhe: que, imitando o exemplo de Timão, retire-se para um deserto, para aí gozar à vontade dos frutos de sua sabedoria” (pp. 42-3) ${ }^{292}$

As referências à Casa Verde (a novidade da Rua Nova), bem como à Câmara dos Vereadores, à barbearia e à casa do albardeiro Mateus não dizem respeito apenas ao elemento urbano. Marcam as diferenças entre uma camada social e outra ${ }^{293}$. Caberia averiguar o porquê de o escorregadio Padre Lopes não ter sua paróquia sequer mencionada. Ao narrador interessam suas palavras e não sua ocupação, como pároco.

O andarilho Gonzaga de Sá, embora ligado historicamente à própria capital da República, de certo modo, nega o procedimento típico de um idoso tradicional saudoso do Império. Em lugar de requerer as certezas durante os diálogos com Augusto Machado, expõe suas “teorias” sobre nossa sociedade com a despretensão de um sábio, sobrinho que é de Escolástica. A esse respeito, aliás, observe-se o tom professoral, didático do romance.

Sua aversão ao pedantismo pediu um registro breve, filiado ao gênero mais próximo do trato cotidiano: a crônica. Várias podem ser as razões para a estruturação do romance que emprega diálogos concentrados nas vozes de Gonzaga e Augusto:

“durante o discurso direto, o narrador já não tem o privilégio de impor o seu 'tempo', mas é obrigado a seguir uma ordem temporal mais objetiva. O que ganha em troca? Vê-se logo que o discurso direto dá mais vivacidade e tensão à narrativa. No encurtamento da perspectiva que vai, no discurso direto, até à sua completa anulação, reside uma variedade que agrada e que impede toda a monotonia. O público gosta também de ouvir, ocasionalmente, a voz de uma outra personagem diferente da do narrador. (...) o discurso direto exerce ainda outras funções além das

\footnotetext{
292 Elogio da loucura.

293 Conforme Nelson Omegna: "Há uma característica comum no conspecto urbanístico dessas pequenas e pobres vilas da colônia - o artificialismo manifesto na pompa das edificações oficiais ou eclesiásticas, em contraste com a modéstia das residências e a importância do povoado." (p. 42) "Esse mal de ostentar não é responsável tão somente pelo excesso de certas edificações, mas também pela desproporção entre o vulto e aparato da obra e o seu real sentido de utilidade.” (Op. Cit., p. 47).
} 
da variedade. Já na vida quotidiana se observa que, por mais pormenorizados que sejam os relatos dos nossos melhores amigos sobre determinada pessoa, nos vale mais um encontro pessoal com ela para chegar a uma idéia clara sobre o seu caráter.” (pp. 308-9) ${ }^{294}$

\section{II}

Em Milícias, O Alienista e Gonzaga de Sá a linguagem dos convivas ou do pessoal de gabinete revela indícios da visão que desde então fazíamos de nós mesmos. Entretanto, enquanto os dois primeiros recorreram à cena, o último se valeu do panorama, de acordo com a terminologia de Percy Lubbock. ${ }^{295}$

Recorde-se que, para Lubbock, a cena (o mostrar) leva a priorizar a descrição, ao passo que o panorama (o contar) é empregado preferencialmente para referendar o drama Desse modo, a cena se ajusta ao diálogo, o contato imediato do leitor com o movimento e uma forte sensação do curso do tempo. Já o quadro (ou panorama) privilegia a descrição e a estaticidade, dois traços marcantes do romance barretiano. É que em Gonzaga de Sá o destino do protagonista não parece interessar tanto quanto as idéias que lega ao amigo Augusto.

A respeito de Augusto Machado, diga-se ainda que se trata de um "narrador enquadrado”, tomando a definição de Wolfgang Kayser. ${ }^{296}$ Dispomos de seu nome e sobrenome, hábitos e profissão. É plausível darmos maior confiança a um narrador identificado e claramente situado, socialmente, do que a narradores anônimos que eventualmente deixam brechas entre os episódios que narram.

Vê-se que Augusto e Gonzaga foram configurados como entidades mais próximas, inclusive temporalmente, do universo do leitor, diferentemente do que acontece com o vagal Leonardo-filho de Almeida e o médico quase surreal de Machado - elaborados como figuras de tempos remotos, tão afastados temporalmente que ganham contorno de sujeitos lendários, apesar de certa sensação de "presente” vivaz.

Possivelmente Lima Barreto valeu-se de tais características, ao enformar narrador e protagonista para, sem recorrer aos expedientes dos naturalistas, aclarar a mensagem que desejava transmitir aos leitores, fugindo, por outro lado, à costumeira ambigüidade dos narradores machadianos, por exemplo.

\footnotetext{
${ }^{294}$ Wolfang Kayser. Op. Cit., Vol. 1.

${ }^{295}$ A técnica da ficção.

296 “A narrativa enquadrada é um meio técnico excelente para satisfazer uma exigência basilar que o leitor reclama da arte de narrar: isto é, a credibilidade do que se narra. Formam uma exceção as 'histórias de patranhas' (Lügengeschichten), existentes em todas as literaturas. Mas precisamente o fato de este tipo de narrativa ser constituído como tal pelo seu caráter 'mentiroso', mostra que em todos os outros casos inexoravelmente se impõe a credibilidade.” (Op. Cit., pp. 311-2).
} 
No que diz respeito à forma, Almeida e Machado estão mais próximos: narradores anônimos em terceira pessoa que intervêm nas cenas que descrevem e ações que narram; caracterização cômica de personagens e respectivas posturas. Desmoralizar para julgar: o desejo de "verdade” de Manuel Antônio de Almeida e Machado de Assis difere do modo barretiano porque naqueles, a intenção implícita é comunicar verdades mal escondidas na trajetória das figuras, remetidas para além dos domínios ficcionais.

O gosto pela oratória e o elemento burocrático, fortemente enraizado com o advento da corte brasileira postiça, parece ter levado os três escritores a adotar a representação bem-humorada das formalidades, servindo a disfarçar o desconforto frente à inadiável necessidade de privilegiar ou re-valorizar os referenciais que caracterizaram nossa cultura, em constante por fazer. Daí um dos papéis da literatura, nas palavras de Lima Barreto:

“a arte literária se apresenta com um verdadeiro poder de contágio que a faz facilmente passar de simples capricho individual, para traço de união, em força de ligação entre os homens, sendo capaz, portanto, de concorrer para o estabelecimento de uma harmonia entre eles, orientada para um ideal imenso, em que se soldem as almas, aparentemente mais diferentes” (p. 62) ${ }^{297}$

\section{III}

Há um tanto de mandonismo, dominação e impotência na fatura das três narrativas: arbitrariedades dos homens da lei no Reino e na República de anomias. Marginal e herói podem ser epítetos complementares, se não equivalentes.

O mandonismo cede terreno ao potente Leonardo-filho; a dominação de Bacamarte não contava com a sua impotência de cunho teórico; e a impotência de Gonzaga questiona a dominação legalmente instituída, emparelhada com o mandonismo de igual teor burocrático.

De uma forma ou de outra, a potência de Vidigal cede para a de Leonardo-filho. A impotência teórica de Bacamarte perde para sua prepotência revestida de ciência pura. E a impotência de Gonzaga de Sá choca-se com a prepotência de seus conterrâneos ao mesmo tempo em que as convicções do sexagenário ganham amplitude no jovem, e presumivelmente mais potente, Augusto Machado.

Nos três casos, fachadas. Nada mais apropriado e convincente aos olhos alheios, ao exercer o mando ou reafirmar o domínio, que a cara pensante, o gesto demorado e as vestes de um pretenso equilíbrio de tons e caimento, condizentes com o ambiente de representação social.

\footnotetext{
297 "O destino da literatura”.
} 
Por isso, é só no final do romance que a troca das peças de roupa de Vidigal são referidas. Só quando pego de surpresa (mora sugestivamente na “Rua da Misericórdia”), sem o aparato da "alma exterior", é que o major, de certo modo, cede parte do mando que detinha a Leonardo-filho. Uma confusão do representante máximo da lei, entre a suposta retidão de caráter (a face pública, encarnada no mando) e o "jeitinho" desmedido (o lado privado, motivado pelo desejo por laços carnais com Maria, a Regalada):

"O major recebeu-as de rodaque de chita e tamancos, não tendo a princípio suposto o quilate da visita; apenas porém reconheceu as três, correu apressado à camarinha vizinha, e envergou o mais depressa que pôde a farda; como o tempo urgia, e era uma incivilidade deixar sós as senhoras, não completou o uniforme, e voltou de novo à sala de farda, calças de enfiar, tamancos, e um lenço de Alcobaça sobre o ombro, segundo seu uso.” (p. 321) ${ }^{298}$

Por motivo similar é que a indumentária de Simão Bacamarte - a única descrita com riqueza de detalhes, na novela - é desenhada no derradeiro capítulo: aquele em que sua aparência de douto, sábio e bem posto socialmente serve de contrapeso ao veredicto de que curar é pretensão somente viabilizada porque autorizada pela lei, o costume e a força dos dragões reais. A minuciosa descrição da roupa - em associação aos gestos caricatos do "sábio", espalhados na narrativa - demarca na forma a supremacia do que é (fachada teórica) sobre o que parecia ser (cura):

"Um amplo chambre de damasco, preso à cintura por um cordão de seda, com borlas de ouro (presente de uma Universidade) envolvia o corpo majestoso e austero do ilustre alienista. A cabeleira cobria-lhe uma extensa e nobre calva adquirida nas cogitações quotidianas da ciência. Os pés, não delgados e femininos, não graúdos e mariolas, mas proporcionados ao vulto, eram resguardados por um par de sapatos cujas fivelas não passavam de simples e modesto latão.” (p. 286)

Com Gonzaga de Sá acontece algo parecido, nos capítulos finais do romance. Ao replicante e impotente combina-se o peso da idade e a frustração manifestada num discurso amargo que refere os quinze anos transcorridos lentamente na função pública, em atribuições de utilidade questionável.

"Gonzaga de Sá trajava rigorosamente de preto, conforme seu hábito, mas, em vez do paletósaco, trazia a grave sobrecasaca. Era a primeira vez que eu o via com esse traje, tão querido dos doutores e comendadores; e o meu despretensioso amigo aparecia-me, assim, com a respeitabilidade precoce de um jovem ministro.” (p. 64)

\section{IV}

No fim das contas, o que parece estar em questão é a ordem, o funcionamento das coisas (política, polícia, costumes, cultura). Quem diz ordem refere-se à manutenção das formas de poder. O poder, portanto, depende de constante exercício. Serve de

\footnotetext{
298 é a "psicologia especial a que [o vestir-se de acordo com a tendência dominante] dá origem (...) a vestimenta confundindo-se com a própria vida em sociedade”. Gilda de Mello e Souza, Op. Cit., p. 141.
} 
parâmetro social tanto aos mandões quanto aos impotentes, já que é através das suas manifestações que autoriza uns a agir em detrimento de outros e outros a reagir contra alguns.

Mandar, caso de Vidigal, difere de dominar porque se liga a certos modos de execução sob o nome da ordem, o amparo das leis e costumes. Dominar, postura de Bacamarte, significa exercer a autoridade não só no sentido vertical (de cima a baixo), mas também na horizontal, inclusive - às vezes, em mesmo nível hierárquico dos dominados. Dominar está ligado a julgar - outra vez com o respaldo de uma prévia autorização política e cultural que vem além do Oceano.

Já a impotência de Gonzaga de Sá constitui uma postura paradoxal porque se trata de uma atitude passiva ante o predomínio de certas arbitrariedades, autorizadas pelo hábito e a lei. Inclua-se aí a burocracia - eixo de sustentação e manutenção da hierarquia. Esta, supostamente justificada sob formas fixas: mais nos costumes que nas regras.

\section{$\mathbf{V}$}

À primeira vista, Manuel Antônio de Almeida, Machado de Assis e Lima Barreto podem parecer escritores inconciliáveis. Além de pertencerem a períodos literários diferentes, seu estilo é notadamente diverso.

Mas os três, a um só tempo, negaram a forma convencional a que o público leitor de sua época estava afeito, trazendo para o centro de seus dramas assuntos varridos para baixo do tapete pelos demais escritores, que contavam com o aval de nossa elite política e intelectual. Entretanto, a manobra perdurou sem maiores rebuliços até a revolução levada a cabo pelos escritores modernistas.

Enquanto na ficção dos demais escritores as festas são oportunidades oficiais para os contratos comerciais ou os eventuais enlaces matrimonias entre as famílias da mocinha bela e prendada e do galã de posses, repare-se o tratamento dado a esses encontros, em Milícias, O Alienista e Gonzaga de Sá.

Nas Memórias, Leonardo-filho não é introduzido à casa de Luizinha com o apoio das vestes ou o "glamour" de uma festa de alta roda. Trata-se de uma visita de seu padrinho, o compadre barbeiro, a D. Maria, amiga rica que cuida da sobrinha. Em lugar das formais festas de salão, a visita rápida que só a amizade de dois velhos amigos permitiria. Mas a moça de dotes e prendas não ficará à espera de seu amado irresponsável e sem posses. Influenciada pela tia, Luzinha simbolicamente perde a pureza com o velhaco José Manuel, enquanto se resolvem as coisas para o lado de Leonardo-filho, malandro reformado. 
Na novela machadiana, Bacamarte não se casa com uma beldade virginal menor de idade, mas com a experiente Eva, já viúva de um juiz-de-fora. Fato curioso, por outro lado, porque revela alguma proximidade de Evarista Mascarenhas com dois homens de cargos ligados à administração lusa. Primeiro, com o oficial que fiscalizava o transporte de mercadorias em Minas Gerais; segundo, com o sábio de conhecimento “imarcessível” formado em Pádua e Coimbra. Ambos ocupantes de cargos eminentemente políticos e dotados de amplos poderes outorgados pela coroa.

No romance barretiano, basta relembrar o fato de Gonzaga de Sá fazer raras alusões a sua vida pessoal. Não parece haver espaço para muitas cortesias, em Vida $e$ morte de M. J. Gonzaga de Sá. Aqui, como acontece no romance de Almeida e, em menor medida, na novela de Machado, impera o diálogo entre figuras de diversas extrações sociais. Nos termos de Wolfgang Kayser:

"A conversa como unidade fechada em si, como parte relativamente independente do conjunto, aparece sobretudo no romance de sociedade dos séculos XIX e XX. Serve então para concretizar e realizar uma determinada camada social ou grupo de pessoas, e assim é um processo adequado ao fim do romance de sociedade.” (p. 343) ${ }^{299}$

Fugindo aos padrões literários de seu tempo, Almeida, Machado e Lima são autores cujas obras poderiam ser lidas não apenas em função de demarcar a periodização literária. Trata-se de manifestações esporádicas, mas talvez complementares, principalmente do ponto de vista ideológico.

Por que escrever contra a convenção? Para conquistar um novo mercado de leitores? Para refletir sua postura autocrítica, tendo em vista o processo de maturação do país? Para municiar os leitores ainda acostumados a uma literatura produzida principalmente para preencher o ócio dos consumidores de jornais? Como afirma Jonathan Culler:

"A literatura não apenas fez da identidade um tema; ela desempenhou um papel significativo na construção da identidade dos leitores. O valor da literatura há muito tempo foi vinculado às experiências vicárias dos leitores, possibilitando-lhes saber como é estar em situações específicas e desse modo conseguir a disposição para agir e sentir de certas maneiras.” (p. $110)^{300}$

Por que as Memórias de um Sargento de Milícias viraram romance? Para escapar ao âmbito da imprensa e obter maior espaço para a divulgação de certas idéias, imiscuídas à narrativa? Para abranger outro público e gerar divisas ao escritor, que imaginava reeditar o relativo sucesso da versão editada no periódico?

\footnotetext{
${ }^{299}$ Op. Cit., Vol. 1

${ }^{300}$ Teoria literária: uma introdução.
} 
“O século XIX lia pelo prazer da leitura”, lembra Erich Auerbach. ${ }^{301}$ Almeida, Machado e Lima enfrentaram os padrões estéticos de seu tempo, resistindo às fórmulas mais brandas, vistas em nosso Romantismo e Realismo. Em lugar de escrever com a finalidade estrita de servir de passatempo aos leitores, abordaram o sério, ainda que de forma alegre e divertida - como acontece nas Memórias de um Sargento de Milícias e em O Alienista - ou sóbria e ligeira, como se percebe na Vida e morte de M. J. Gonzaga de Sá.

\title{
“A vida é uma ópera”
}

\begin{abstract}
"Satanás suplicou ainda, sem melhor fortuna, até que Deus, cansado e cheio de misericórdia, consentiu em que a ópera fosse executada, mas fora do céu. Criou um teatro especial, este planeta, e inventou uma companhia inteira, com todas as partes, primárias e comprimárias, coros e bailarinos.” (Dom Casmurro, p. 818)
\end{abstract}

Aceitando-se o fato de que na cidade urbanizada as relações sociais se ressentem de uma maior complexidade, o peso das instituições coletivas aumenta na mesma proporção. Nas Memórias de um Sargento de Milícias, O Alienista e em Vida e morte de M. J. Gonzaga de Sá, o que está em jogo são justamente as instituições, sejam elas entendidas como manutenção da ordem (Vidigal X Leonardo-filho), critério de normalidade (alienista X alienados) ou índice de modernidade (arrivistas X Gonzaga de Sá).

O Rio de Janeiro de Manuel Antônio de Almeida é um território bem guardado, favorecido pelo trabalho das milícias reais. Mas, se a proteção das tropas e dos meirinhos é colocada em evidência, serve justamente a realçar o efeito das aparências. Nem o numeroso efetivo dos milicianos é capaz de conter o sujeito escorregadio que é Leonardo-filho.

Machado de Assis centra as ações em Itaguaí, vila que, apesar de modesta no tamanho e de população reduzida, está em mesmo nível de ostentação que a capital do país-colônia - vide o recém inaugurado Passeio Público e seu vistoso Chafariz das Marrecas, visitado pela comitiva liderada pela esposa de Simão Bacamarte.

Já o Rio de Lima Barreto está marcado pela acelerada modernização e reurbanização. Republicano e novo por fora; Imperial e conservador, no íntimo, mas ao abrigo das fachadas de um mundo cosmopolita. No Brasil, “europeizar” também significou ordenar sem lei, ostentar sem distribuir e modernizar sem avançar.

\footnotetext{
${ }^{301}$ Introdução aos estudos literários, p. 237.
} 
Certos detalhes assentados na trajetória de figuras, atípicas por dentro e quase típicas por fora, permitem questionar as motivações dos respectivos protagonistas.

Leonardo-filho subverte a ordem pelo gosto da baderna ou para desafiar as instiuições luso-brasileiras? Simão Bacamarte estuda a loucura por vaidade ou pelo amor desinteressado à ciência? Gonzaga de Sá filosofa para abreviar o tempo até sua morte ou para formar as opiniões do jovem Augusto, símbolo da mocidade?

Pode-se dizer que o que os aproxima formalmente é um desejo de realismo. Não o estritamente literário, percebido na coerência interna de sua obra, mas o anticonvencional, no sentido de que se colocavam entre o "velho romantismo idealista", e o objetivismo estrito, o “realismo utilitário”302, também estimado pelos naturalistas.

A intenção de comunicar "realismo" encontra modos diferenciados nesses escritores. Almeida renega o traço idealizador e edificante dos prosadores românticos; Machado satiriza os valores científicos do período positivista e Lima Barreto, sem recorrer a aventuras ou teorias surreais, vale-se de um velho funcionário público para lidar com os temas mais espinhosos vinculados a nossa formação sociocultural.

Memórias de um Sargento de Milícias é "realista” na medida em que se ocupa da descrição aparentemente fiel dos costumes e das figuras envolvidas em festividades e demais aventuras. Mas é principalmente anti-idealista, pois se serve do ponto de vista em terceira pessoa para, contrariamente aos românticos, mostrar que leitor e narrador talvez não estivessem tão distantes dos mesmos fatos históricos e suas implicações.

O tom de gracejo contribui decisivamente para contrapor-se ao romance de seus contemporâneos, embora sua narrativa repleta de aventuras originalmente se destinasse ao público que também lia as obras de Alencar ou Macedo - estes caracterizados pelo tom solene e o respaldo moralizante.

O Alienista é “realista” não na forma, mas na intenção de embaralhar a percepção do leitor. Dono de um enredo rocambolesco e fantasioso, o narrador age de forma similar ao das Memórias de um Sargento de Milícias. Sua meta parece ser desmistificar a leitura convencional de ficcão.

A narrativa poderia levar o leitor a questionar as intenções do próprio narrador e, em conseqüência, o seu próprio papel de consumidor de literatura. Leio para me divertir com o enredo repleto de peripécias ou com o fato de uma novela revelar em sua fatura de enredo incomum e narrador fuxiqueiro quão tênue é o limite entre o universo literário e o meu, de leitor?

\footnotetext{
${ }^{302}$ Termos de Alfredo Bosi em O enigma do olhar, p. 81.
} 
A idéia de "realismo", no sentido de mimese da realidade, é mais evidenciada no romance de Lima Barreto. Ao enredo nada hiperbólico, construído basicamente sobre os diálogos de duas personagens de classe mediana, combina-se o tom grave, favorecido pela linguagem simples e direta do narrador-testemunha, cujo estilo parece contagiado pelo desânimo do velho amigo falecido. O livro dispensa os torneios descritivos, as paixões mal resolvidas ou os golpes financeiros. O que interessa a Lima, mais que distrair, é instrumentar ideologicamente o seu leitor.

Considerando os contrapontos entre realidade e fantasia, Milícias combina um e outro aspecto, aproveitando-se em parte da história de nossos costumes e apoiado nos testemunhos das possíveis fontes do autor - habilidoso em inventar estripulias. A novela de Machado é fantasiosa no tema, mas verossímil na forma. E o romance de Lima parece mais fincado na realidade, ancorado na credibilidade também concedida pelo testemunho de Augusto, jovem íntimo das idéias de Gonzaga.

É que, diferentemente do que acontece nas Memórias de um Sargento de Milícias e, de forma mais evidente, em O Alienista, em Vida e morte de M. J. Gonzaga de Sá não parece haver espaço para a fantasia, mas só o fato, a sinceridade e a contundência. Quando muito, há raros e breves devaneios por parte do narrador.

Aceitando a síntese de Raúl Castagnino ${ }^{303}$, o romance de Almeida e a novela de Machado aproximam-se do gênero épico, já que nessas narrativas a ênfase recai nos feitos dos homens. Além disso, nos dois casos as ações se localizam no pretérito, em uma estranha combinação com certo otimismo que o tom anedótico transmite.

Já o romance de Lima Barreto estaria mais próximo do drama, uma vez que o alvo não está no enredo, mas nos conflitos. Contrariamente às obras de Almeida e Machado, o pessimismo marcado pelas soturnas reflexões de Gonzaga e Augusto é quase um contrapeso ao anseio por um futuro melhor, levemente sugerido nas páginas finais.

Trata-se de três narrativas biográficas que giram em torno de protagonistas. A ênfase na trajetória das personagens está em acordo com a particularização que caracteriza a ficção pós-romântica. Em lugar da experiência coletiva, as peripécias ou as reflexões individuais, nos termos de Ian Watt: “certamente o romance se diferencia dos outros gêneros e de formas anteriores de ficção pelo grau de atenção que dispensa à individualização das personagens e à detalhada apresentação de seu ambiente.”(p. 19) ${ }^{304}$

\footnotetext{
${ }^{303}$ Op. Cit., p. 60.

${ }^{304}$ A ascensão do romance.
} 
A pormenorização dos caracteres das personagens bem como de suas trajetórias não impediu que temas universais fossem desnudados nas três narrativas. $\mathrm{E}$ ao enfrentar tais questões, os três escritores revelaram algo de moralizante em suas obras, ainda que para contradizer um outro "moralismo" apolítico, idealizante e mitificador, percebido nos românticos e realistas convencionais.

Viver intensamente o presente (Leonardo), antecipar teorias do futuro (Simão) e agarrar-se ao pretérito (Gonzaga): o malandro é um ser de atitudes que só revertem em benefício próprio; o médico está fora de tempo e lugar e Gonzaga é um anacrônico, saudoso assumido do Império.

Manuel Antônio de Almeida, Machado de Assis e Lima Barreto compõem uma tríade de escritores especializados em abordar determinadas posturas dos homens de uma sociedade em formação, ministrando literatura como remédio, ora doce ora amargo, sempre com altas doses de sarcasmo e ironia, mas nenhuma complacência. 


\section{Bibliografia}

\section{De Manuel Antônio de Almeida}

ALMEIDA, Manuel Antônio de. Memórias de um sargento de milícias. Cotia: Ateliê Editorial, 2003 (Edição de Mamede Mustafa Jarouche).

. Memórias de um sargento de milícias. São Paulo: Globo, 2004 (Edição de Reginaldo Pinto de Carvalho).

. Obra dispersa. Rio de Janeiro: Graphia, 1991 (Edição de Bernardo de Mendonça).

\section{Sobre Manuel Antônio de Almeida}

ANDRADE, Mário de. "Memórias de um sargento de milícias”. In: Aspectos da literatura brasileira. 5ªed. São Paulo: Martins, 1974.

CANDIDO DE MELLO E SOUZA, Antonio. "Manuel Antônio de Almeida: o romance em moto contínuo" In: Formação da literatura brasileira (momentos decisivos). $6^{\text {a }}$ ed. Belo Horizonte: Itatiaia, 2000. $2^{\circ}$ Vol.

. "Dialética da malandragem” In: O discurso e a cidade. São Paulo: Duas Cidades, 2004.

CARVALHO, Reginaldo Pinto de. "A autocensura nas Memórias de um sargento de milícias" In: ALMEIDA, Manuel Antônio de. Memórias de um sargento de milícias. São Paulo: Globo, 2004.

CARVALHO, Ronald. Pequena história da literatura brasileira. $10^{\mathrm{a}}$ ed. Rio de Janeiro: F. Briguiet, 1955.

COUTINHO, Afrânio. "Introdução" In: ALMEIDA, Manuel Antônio de. Memórias de um sargento de milícias. Rio de Janeiro: Tecnoprint, s/d.

DAMASCENO, Darcy. “Afetividade lingüística nas Memórias de um sargento de milícias”. Revista brasileira de filologia. V. 2, tomo II. Rio de Janeiro: Livraria Acadêmica, 1956.

GALVÃO, Walnice Nogueira. "No tempo do rei” In: Saco de gatos: ensaios críticos. São Paulo: Duas Cidades/Secretaria da Cultura, Ciência e Tecnologia do Estado de São Paulo, 1976.

GOMES, Eugênio. "Manuel Antônio de Almeida” In: Salvador: Universidade da Bahia/Progresso, 1958. . Aspectos do romance brasileiro.

GOTO, Roberto. “O narrador malandro” In: Malandragem revisitada. São Paulo: Pontes, 1988.

HADDAD, Jamil Almansur. "Prefácio” In: ALMEIDA, Manuel Antônio de. Memórias de um sargento de milícias. $4^{\mathrm{a}}$ ed. São Paulo: Melhoramentos, 1962.

JAROUCHE, Mamede Mustafa. "Galhofa sem melancolia: as Memórias num mundo de Luzias e Saquaremas”. In: ALMEIDA, Manuel Antônio de. Memórias de um sargento de milícias. Cotia: Ateliê Editorial, 2003. 
LINHARES, Temístocles. "Um fenômeno de criação literária” In: História crítica do romance brasileiro. Belo Horizonte: Itatiaia; São Paulo: Edusp, 1987.

MONTELO, Josué. “Um precursor: Manuel Antônio de Almeida” In: COUTINHO, Afrânio; GOMES, Eugênio e BARRETO FILHO. A literatura no Brasil. Rio de Janeiro: Livraria São José/Editorial Sul Americana, 1955.

REBÊLO, Marques. Vida e obra de Manuel Antônio de Almeida. Rio de Janeiro: Ministério da Educação e Saúde/Instituto Nacional do Livro, 1943.

RÓNAI, Paulo. "Préface” In: ALMEIDA, Manuel Antônio de. Mémoires d'um sergent de la milice. Tradução para o francês de Paulo Rónai. Rio de Janeiro: Atlántica, 1944.

SCHWARZ, Roberto. "Pressupostos da Dialética da malandragem salvo engano” In: Que horas são? São Paulo: Companhia das Letras, 1997.

TÁTI, Miécio. Estudos e notas críticas. Rio de Janeiro: MEC/INL, 1958.

WALDMAN, Berta. "O romântico fruto de uma pisadela e de um beliscão" In: ALMEIDA, Manuel Antônio de. Memórias de um sargento de milícias. São Paulo: FTD, 1992.

ZAGURY, Eliane. "Apresentação" In: ALMEIDA, Manuel Antônio de. Memórias de um sargento de milícias. $10^{\mathrm{a}}$ ed. São Paulo: Ática, 1980.

De Joaquim Maria Machado de Assis

MACHADO DE ASSIS, Joaquim Maria. Obra completa. Rio de Janeiro: Nova Aguilar, 1992. vol. 2.

Sobre Machado de Assis

ALVES, Constancio. "Machado de Assis” In: Brasil, 1921.

Figuras. Rio de Janeiro: Annuario do

BARRETO FILHO, José. Introdução a Machado de Assis. Rio de Janeiro: Agir, 1980.

BOSI, Alfredo. Machado de Assis: o enigma do olhar. São Paulo: Ática, 1999.

Brás Cubas em três versões: estudos machadianos. São Paulo: Companhia das letras, 2006.

BOSI, Alfredo; GARBUGLIO, José Carlos; CURVELLO, Mario e FACIOLI, Valentim Aparecido. Machado de Assis. São Paulo: Ática, 1982.

BRITO BROCA. Machado de Assis e a política: mais outros estudos. São Paulo: Polis; Brasília: INL, 1983.

BRUNEL, Pierre. "Itaguaí ou le grand thêatre du monde” In: Machado de Assis. L'Aliéniste. Paris: Métailié, 1984.

CANDIDO DE MELLO E SOUZA, Antonio. "Esquema de Machado de Assis” In: Vários escritos. $3^{\mathrm{a}}$ ed. São Paulo: Duas Cidades, 1995.

CANDIDO JUCÁ FILHO. O pensamento e a expressão em Machado de Assis. Rio de Janeiro: Civilização Brasileira, 1939. 
CAVALCANTI PROENÇA, Manuel. "Introdução" In: MACHADO DE ASSIS. O Alienista $\boldsymbol{e}$ outras histórias. Rio de Janeiro: Tecnoprint, 1996.

CHAVES, Flávio Loureiro. O mundo social do Quincas Borba. Porto Alegre: Movimento, 1974.

D’AMBROSIO, Oscar. "O desalienante realismo de Machado de Assis” In: ALMEIDA, Arlenice et al. A supremacia do conto. São Paulo: Selinunte, 1994.

DIXON, Paul. "Modelos em movimento: os contos de Machado de Assis". Revista Teresa, n. 6/7. São Paulo: FFLCH/USP, 2006.

FAORO, Raymundo. Machado de Assis: a pirâmide e o trapézio. São Paulo: Companhia Editora Nacional, 1974.

FREITAS, Maria Eurides Pitombeira de. O grotesco na criação de Machado de Assis e Gregório de Matos. Rio de Janeiro: Presença, 1981.

GARBUGLIO, José Carlos. "Apresentação” In: Machado de Assis. O Alienista. $13^{\mathrm{a}}$ ed. São Paulo: Ática, 1988.

. “A composição e a decomposição” In: Machado de Assis. Quincas Borba. $7^{\mathrm{a}}$ ed. São Paulo: Ática, 1988.

GLEDSON, John. Machado de Assis: ficção e história. Tradução: Sônia Coutinho. Rio de Janeiro: Paz e Terra, 1986.

. "Os contos de Machado de Assis: o machete e o violoncelo". In: Machado de Assis. Contos completos. São Paulo: Companhia das Letras, 1998. V. 1.

GOMES, Eugênio. O enigma de Capitu. Rio de Janeiro: José Olympio, 1967.

. "Machado de Assis" In: . Aspectos do romance brasileiro. Salvador: Universidade da Bahia/Progresso, 1958.

GRAÇA, Antônio Paulo. A catedral da impureza: crítica da razão liberal. São Paulo: Imaginário, 1992.

GRANJA, Lúcia. Machado de Assis, escritor em formação (à roda dos jornais). Campinas: Mercado de Letras/Fapesp, 2000.

GUIDIN, Márcia Lígia. Armário de vidro: a velhice em Machado de Assis. São Paulo: Nova Alexandria, 2000.

GUIMARÃES, Hélio de Seixas. Os leitores de Machado de Assis: o romance machadiano e o público de literatura no século 19. São Paulo: Nankin Editorial/Edusp, 2004.

LIMA, Luiz Costa. “O palimpsesto de Itaguaí” In: José, nº 3. Rio de Janeiro: Fontana, 1976.

LOPES, José Leme. A psiquiatria de Machado de Assis. 2ª ed. Rio de Janeiro: Agir, 1981.

MAJOR NETO, José Emílio. “O Alienista de Machado de Assis” In: Machado de Assis. $\boldsymbol{O}$ Alienista. São Paulo: Princípio, 1993. 
MERQUIOR, José Guilherme. "Machado de Assis e a prosa impressionista" In: De Anchieta a Euclides: breve história da literatura brasileira - I. Rio de Janeiro: José Olympio, 1977.

MASSA, Jean-Michel. A juventude de Machado de Assis - 1839-1870: ensaio de biografia intelectual. Tradução: Marco Cornélio de Moura Matos. Rio de Janeiro: Civilização Brasileira, 1971.

MEYER, Augusto. “Na casa verde” In: Machado de Assis. 2a ed. Rio de Janeiro: Simões, 1952.

MOISÉS, Massaud. "Notas preliminares” In: Machado de Assis. Memorial de Aires / O Alienista. São Paulo: Cultrix, 1961.

. Machado de Assis: fiç̧ão e utopia. São Paulo: Cultrix, 2001.

PASSOS, Gilberto Pinheiro. O Napoleão de Botafogo: presença francesa em Quincas Borba de Machado de Assis. São Paulo: Annablume, 2000.

PEREIRA, Astrojildo. Machado de Assis - ensaios e apontamentos avulsos. $2^{\mathrm{a}}$ ed. Belo Horizonte: Oficina de Livros, 1991.

PEREIRA, Lúcia Miguel. Machado de Assis: estudo crítico e biográfico. $6^{\text {a }}$ ed. Belo Horizonte: Itatiaia; São Paulo: Edusp, 1988.

RIEDEL, Dirce Côrtes. Metáfora, o espelho de Machado de Assis. Rio de Janeiro: Francisco Alves, 1974.

SCHNAIDERMAN, Boris. “O Alienista, um conto dostoieviskiano?” Revista Teresa, n. 6/7. São Paulo: FFLCH/USP, 2006.

SCHWARZ, Roberto. Um mestre na periferia do capitalismo: Machado de Assis. São Paulo: Duas Cidades, 1990.

. Ao vencedor as batatas. $4^{\mathrm{a}}$ ed. São Paulo: Duas Cidades, 1992.

SOARES, Maria Nazaré Lins. Machado de Assis e a análise da expressão. Rio de Janeiro: INL, 1968.

VERÍSSIMO, José. “Machado de Assis” In: de Janeiro: José Olympio, 1954. História da literatura brasileira. $3^{\mathrm{a}}$ ed. Rio

\section{De Afonso Henriques de Lima Barreto}

LIMA BARRETO, Afonso Henriques de. Vida e morte de M. J. Gonzaga de Sá. São Paulo: Ática, 1997.

. Triste fim de Policarpo Quaresma. 12ª ed. São Paulo: Ática, 1994.

. Os Bruzundangas. São Paulo/Belo Horizonte: Garnier, 1998.

. A nova Califórnia - contos. São Paulo: Brasiliense, 1979.

Impressões de leitura: crítica. São Paulo: Brasiliense, 1956. 


\section{Sobre Lima Barreto}

AIEX, Anoar. As idéias sócio-literárias de Lima Barreto. São Paulo: Vértice/Editora Revista dos Tribunais, 1990.

BARBOSA, Francisco de Assis. A vida de Lima Barreto. $5^{\text {a }}$ ed. Rio de Janeiro: José Olympio; Brasília: INL, 1975.

CANDIDO DE MELLO E SOUZA, Antonio. "Os olhos, a barca e o espelho" In: A educação pela noite \& outros ensaios. $3^{\text {a }}$ ed. São Paulo: Ática, 2000.

CAVALCANTI PROENÇA, Manuel. "Prefácio" In: LIMA BARRETO. Impressões de leitura: crítica. São Paulo: Brasiliense, 1956.

FIGUEIREDO, Carmen Lúcia Negreiros de. Lima Barreto e o fim do sonho republicano. Rio de Janeiro: Tempo Brasileiro, 1995.

. Trincheiras do sonho - ficção e cultura em Lima Barreto. Rio de Janeiro: Tempo Brasileiro, 1998.

GOMES, Eugênio. "Lima Barreto” In: Aspectos do romance brasileiro. Salvador: UFBA/Progresso, 1958.

HOLANDA, Sérgio Buarque de. "Em torno de Lima Barreto” In: Cobra de vidro. $2^{\text {a }}$ ed. São Paulo: Perspectiva, 1978.

LIMA, Alceu Amoroso. "Introdução" e "Nota prévia” In: Lima Barreto. Vida e morte de M. $\boldsymbol{J}$. Gonzaga de Sá. Rio de Janeiro: Ediouro, s/d..$^{305}$

LINS, Osman. Lima Barreto e o espaço romanesco. São Paulo: Ática, 1976.

OLIVEIRA LIMA, M. "Prefácio” In: Lima Barreto. Triste fim de Policarpo Quaresma. São Paulo: Brasiliense, 1956.

PEREIRA, Astrojildo. "Posições políticas de Lima Barreto” In: Crítica impura. Rio de Janeiro: Civilização Brasileira, 1963.

PRADO, Antonio Arnoni. "Ilusões da modernidade em tom irreverente” In: Lima Barreto. Vida e morte de M. J. Gonzaga de Sá. São Paulo: Ática, 1997.

SILVA, H. Pereira da. Lima Barreto - escritor maldito. São Paulo: Brasiliense, 1976.

\section{Sobre História da Literatura e Brasileira e Jornalismo}

BELTRÃO, Luiz. Iniciação à filosofia do jornalismo. $2^{\text {a }}$ ed. São Paulo: Edusp/Com-Arte, 1992.

BOSI, Alfredo. História concisa da literatura brasileira. 39a ed. São Paulo: Cultrix, 2001.

CANDIDO DE MELlO E SOUZA, Antonio e CASTELlO, José Aderaldo. Presença da literatura brasileira. São Paulo: DIFEL, 1964 (3 Vol.).

\footnotetext{
305 A "Introdução" incluía o artigo "Um discípulo de Machado de Assis", publicado em O jornal, em 1919, que Alceu Amoroso Lima assinara como Tristão de Ataíde.
} 
CASTELLO, José Aderaldo. Manifestações literárias do período colonial. $3^{\mathrm{a}}$ ed. São Paulo: Cultrix/Edusp, 1975.

COUTINHO, Afrânio. Introdução à literatura no Brasil. $5^{\mathrm{a}}$ ed. Rio de Janeiro: Ed. Distribuidora de Livros Escolares, 1968

MOISÉS, Massaud. História da literatura brasileira. São Paulo: Cultrix, 1985. Vol.III.

. A literatura brasileira através dos textos. 16ª ed. São Paulo: Cultrix, 1991.

PACHECO, João. O realismo. $2^{\text {a }}$ ed. São Paulo: Cultrix, 1967.

PAES, José Paulo \& MOISÉS, Massaud. Pequeno Dicionário de Literatura Brasileira. São Paulo: Cultrix, 1967.

PEREIRA, Lúcia Miguel. História da literatura brasileira - prosa de fiç̧ão 1870-1920. Belo Horizonte: Itatiaia; São Paulo: Edusp, 1988.

SEVCENKO, Nicolau. Literatura como missão - ilusões sociais e criação cultural na I República. São Paulo: Brasiliense, 1983.

SODRÉ, Nelson Werneck. História da Literatura Brasileira. $6^{a}$ ed. Rio de Janeiro: Civilização Brasileira, 1976.

. Literatura e história no Brasil contemporâneo. Porto Alegre: Mercado Aberto, 1987.

TÁTI, Miécio. "Romancistas do Rio” In: Estudos e notas críticas. Rio de Janeiro: MEC/INL, 1958.

TINHORÃO, José Ramos. Os romances em folhetins no Brasil: 1830 à atualidade. São Paulo: Duas Cidades, 1994.

\section{Sobre Teoria literária}

AUERBACH, Erich. Introdução aos estudos literários. $2^{\mathrm{a}}$ ed. Tradução: José Paulo Paes. São Paulo: Cultrix, 1972.

BAKHTIN, Mikhail. Problemas na poética de Dostoievski. Tradução: Paulo Bezerra. Rio de Janeiro: Forense-Universitária, 1981.

Estética da criação verbal. Tradução: Paulo Bezerra. São Paulo: Martins Fontes, 2003.

CASTAGNINO, Raúl H. Análise literária. Tradução: Luiz Aparecido Caruso. São Paulo: Mestre Jou, 1968.

CHKLOVSKI, V. “A construção da novela e do romance” In: TOLEDO, Dionísio de Oliveira (org.) Teoria da literatura - formalistas russos. $2^{\mathrm{a}}$ ed. Porto Alegre: Globo, 1976.

CULLER, Jonathan. Teoria literária: uma introdução. Tradução: Sandra Vasconcelos. São Paulo: Beca, 1999.

EAGLETON, Terry. Teoria da literatura: uma introdução. Tradução: Waltensir Dutra. São Paulo: Martins Fontes, 2001. 
FORSTER, Edward M. Aspectos do romance. Tradução: Maria Helena Martins. Porto Alegre: Globo, 1969.

FRIEDMAN, Norman. “O ponto de vista na ficção”. Tradução: Fábio Fonseca de Melo. Revista USP, n. 53. São Paulo, 2002.

KAYSER, Wolfang. Análise e interpretação da obra literária. Tradução: Paulo Quintela. $7^{\mathrm{a}}$ ed. Coimbra: Arménio Amado, 1985.

LUBBOCK, Percy. A técnica da ficção. Tradução: Octavio Mendes Cajado. São Paulo: Cultrix/Edusp, 1976.

LUKÁCS, Georg. Ensaios sobre literatura. Rio de Janeiro: Civ. Brasileira, 1965.

MAGALHÃES JUNIOR, Raymundo. A arte do conto. Rio de Janeiro: Bloch, 1972.

WELLEK, René \& WARREN, Austin. Teoria da literatura. 2a ed. Tradução: José Palla e Carmo. Lisboa: Publicações Europa-América, 1962.

\section{Sobre História do Brasil, Sociologia e Antropologia}

ALENCASTRO, Luiz Felipe de. "Vida privada e ordem privada no Império" In: NOVAIS, Fernando A. (coord.) História da vida privada no Brasil: Império. São Paulo: Companhia das Letras, 1997. Vol. 2

BOSI, Alfredo. Literatura e resistência. São Paulo: Companhia das Letras, 2002. . $2^{\mathrm{a}}$ ed. São Paulo: Duas Cidades/Ed. 34, 2003.

CANDIDO DE MELLO E SOUZA, Antonio. Literatura e sociedade. São Paulo: Publifolha, 2000.

CARDOSO, Fernando Henrique. "A cidade e a política: do compromisso ao inconformismo”. In: . Autoritarismo e democratização. Rio de Janeiro: Paz e Terra, 1975.

CARVALHO FRANCO, Maria Sylvia de. Homens livres na ordem escravocrata. $3^{\text {a }}$ ed. São Paulo: Kairós, 1983.

CASTRO ROCHA, João Cezar de. "Dialética da marginalidade" In: Folha de São Paulo (Caderno Mais!). São Paulo, 29/2/2004.

COHN, Gabriel (org.). Max Weber - Sociologia. $3^{\mathrm{a}}$ ed. Tradução: Amélia Cohn e Gabriel Cohn. São Paulo: Ática, 1986.

DaMATTA, Roberto. Carnavais, malandros e heróis. 6ª ed. Rio de Janeiro: Rocco, 1997.

ELIAS, Norbert. A sociedade de corte. Tradução: Ana Maria Alves. Lisboa: Estampa, 1986.

FAORO, Raymundo. Os donos do poder. $3^{\text {a }}$ ed. São Paulo: Globo, 2001.

FAUSTO, Boris. História concisa do Brasil. São Paulo: Edusp/Imprensa Oficial, 2001.

História do Brasil. 12a ed. São Paulo: Edusp, 2004.

FREYRE, Gilberto. Heróis e vilões no romance brasileiro. São Paulo: Cultrix/Edusp, 1979. 
Casa Grande \& Senzala. Rio de Janeiro/Brasília: INL/MEC, 1980.

HILLER, E. T. “Características do status social”. Tradução: Maria Zollner M. de Azevedo Ribeiro. In: CARDOSO, Fernando Henrique e IANNI, Octávio. Homem e sociedade: leituras básicas de sociologia geral. 13ª ed. São Paulo: Companhia Editora Nacional, 1983.

HOLANDA, Sérgio Buarque de. Raízes do Brasil. 26a ed. São Paulo: Companhia das Letras, 1995.

IANNI, Octávio. A idéia de Brasil moderno. São Paulo: Brasiliense, 1996.

LEITE, Dante Moreira. O caráter nacional brasileiro. $4^{\mathrm{a}}$ ed. São Paulo: Pioneira, 1983.

LINTON, Ralph. “O indivíduo, a cultura e a sociedade” In: CARDOSO, Fernando Henrique e IANNI, Octávio. Homem e sociedade: leituras básicas de sociologia geral. $13^{a}$ ed. São Paulo: Companhia Editora Nacional, 1983.

MACHADO NETO, Antônio Luís. Estrutura social da república das letras: sociologia da vida intelectual brasileira, 1870-1930. São Paulo, Grijalbo: Edusp, 1973.

MELLO E SOUZA, Gilda de. O espírito das roupas: a moda no século dezenove. São Paulo: Companhia das Letras, 1987.

NAXARA, Márcia Regina Capelari. Estrangeiro em sua própria terra - representações do brasileiro: 1870/1920. São Paulo: Annablume, 1998.

OLIVEIRA, Francisco de. Crítica à razão dualista/O ornitorrinco. São Paulo: Boitempo, 2003.

OLIVEN, Ruben George. Urbanização e mudança social no Brasil. 2a ed. Petrópolis: Vozes, 1982.

RIBEIRO, Darcy. Os brasileiros: teoria do Brasil. $8^{a}$ ed. Petrópolis: Vozes, 1985.

RIBEIRO, Hélcion. A identidade do brasileiro. Petrópolis: Vozes, 1994.

RIBEIRO, Maria Eurydice de Barros. Os símbolos do poder. Brasília: Editora UNB, 1995.

RODRIGUEZ LOPEZ, Emilio Carlos. Festas públicas, memória e representação: um estudo sobre manifestações políticas na Corte do Rio de Janeiro, 1808-1822. São Paulo: Humanitas, 2004.

SCHWARZ, Roberto. "Prefácio" In: OLIVEIRA, Francisco de. Crítica à razão dualista/O ornitorrinco. São Paulo: Boitempo, 2003.

TÖNNIES, Ferdinand. "Normas sociais: características gerais” Tradução: Leôncio Martins Rodrigues Netto In: CARDOSO, Fernando Henrique e IANNI, Octávio. Homem e sociedade: leituras básicas de sociologia geral. $13^{\mathrm{a}}$ ed. São Paulo: Companhia Editora Nacional, 1983.

TOURINHO, Eduardo. Revelação do Rio de Janeiro. Rio de Janeiro: Civilização brasileira, 1964. 


\section{De Referência}

BOBBIO, Norberto; MATTEUCCI, Nicola e PASQUINO, Gianfranco. Dicionário de política. Brasília: Editora Universitária de Brasília, 1986 (Vários tradutores).

CHALLAYE, Félicien. As grandes religiões. São Paulo: Ibrasa, 1981.

CHEVALIER, Jean \& GHEERBRANT, Alain. Dicionário de símbolos. 2a ed. Tradução: Vera da Costa e Silva; Raúl de Sá Barbosa; Ângela Melim e Lúcia Melim. Rio de Janeiro: José Olympio, 1989.

CIRLOT, Juan-Eduardo. Dicionário de símbolos. Tradução: Rubens Eduardo Ferreira Dias. São Paulo: Editora Moraes, 1984.

FOUCAULT, Michel. História da loucura na Idade Clássica. $4^{\mathrm{a}}$ ed. Tradução: Teixeira Coelho. São Paulo: Perspectiva, 1995.

KUNZMAN, Peter; BURKARD, Franz-Peter e WIEDMANN, Franz. Atlas de la philosophie. Tradução francesa: Zoé Housez e Stéphane Robillard. Paris: La Pochothèque, 1999.

LURKER, Manfred. Dicionário de simbologia. Tradução: Mario Krauss e Vera Barkow. São Paulo: Martins Fontes, 2003.

MOISÉS, Massaud. Dicionário de termos literários. 11ª ed. São Paulo: Cultrix, 2002.

OBATA, Regina. O livro dos nomes. São Paulo: Círculo do Livro, 1986.

VAINFAS, Ronaldo et al. Dicionário do Brasil Colonial (1500-1808). Rio de Janeiro: Objetiva, 2000.

\section{Das Citações}

BAUDELAIRE, Charles. Lo cómico y la caricatura. Traducción: Carmen Santos. Madrid: Visor, 1988.

BERGSON, Henri. Le rire. 303ª ed. Paris: PUF, 1972.

DESCARTES, René. Discurso do método. Tradução: Enrico Corvisieri. São Paulo: Nova Cultural, 1999.

ROTTERDAM, Erasmo de. Elogio da loucura. Tradução: Torrieri Guimarães. São Paulo: Hemus, s/d.

ROUSSEAU, Jean-Jacques. Les rêveries du promeneur solitaire. Paris: Didier, 1964.

STERNE, Laurence. A vida e as opiniões do cavalheiro Tristram Shandy. $2^{\mathrm{a}}$ ed. Tradução: José Paulo Paes. São Paulo: Companhia das Letras, 1998. 